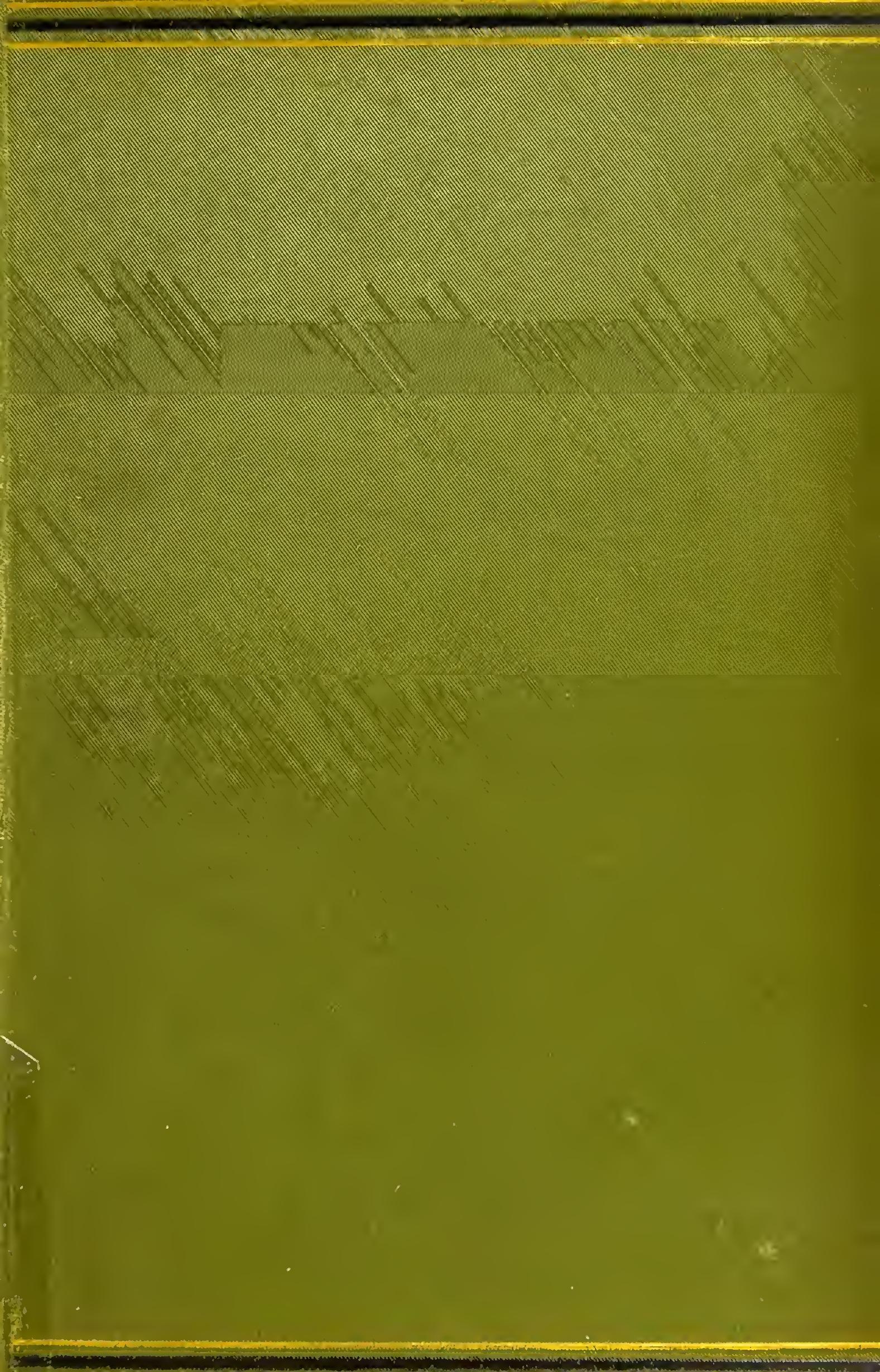

यै 


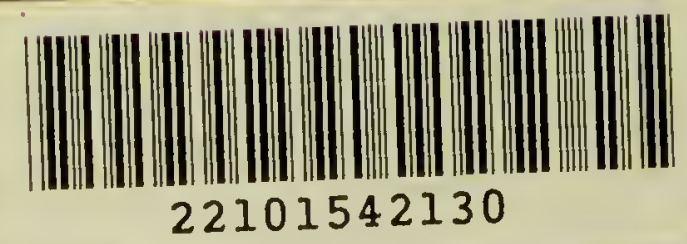


B. Xxiv Bunc 
F Bellows

from A.th.F.

Augunt. 1886 



\section{FRANK BUCKLAND}






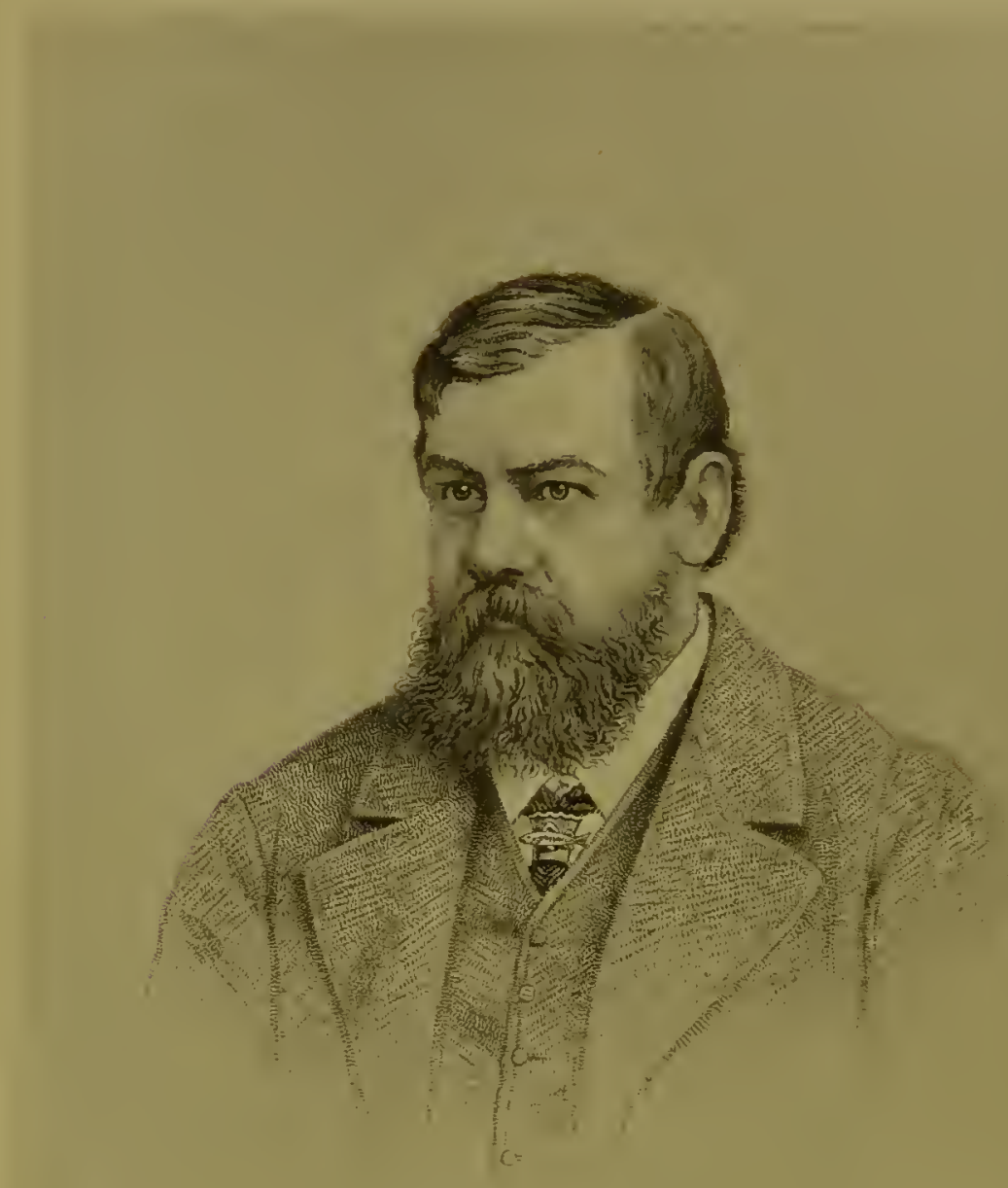

- Trank Puthand 


\title{
LIFE
}

OF

\section{FRANK BUCKLAND}

\author{
BY HIS BROTHER-IN-LAW
}

GEORGE C. BOMPAS

âlith a gortrait

ELEVENTH EDITION

$\mathrm{LONDON}$

SMITH, ELDER, \& CO., 15 WATERLOO PLACF 1886 

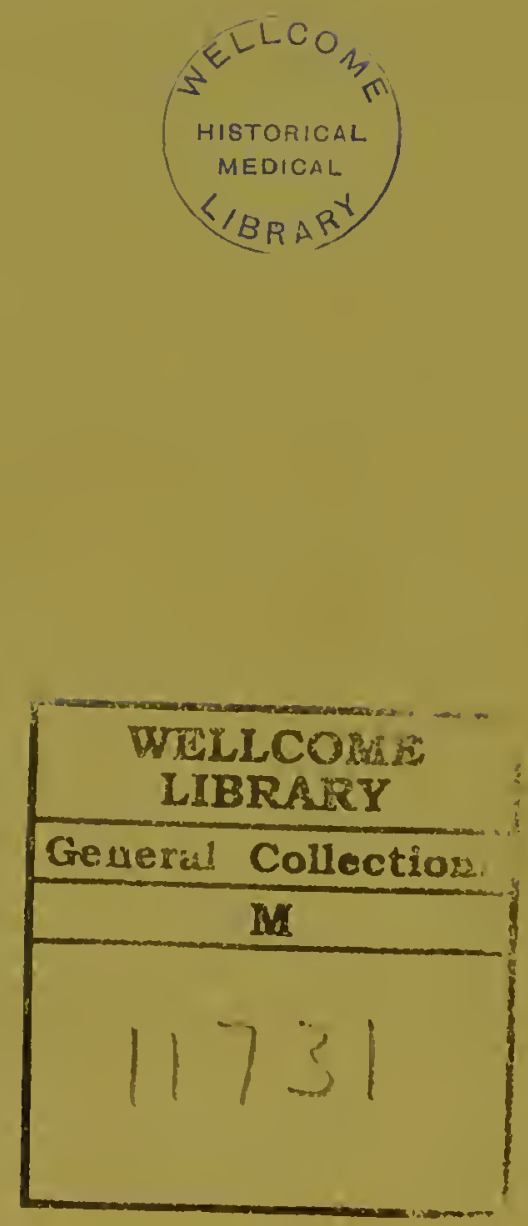


\title{
CONTENTS.
}

\author{
CHAPTER I. \\ CHILDHOOD : 1826-1839.
}

Birth-Parentage-First cabinet-First diary-Duke of Wellington's installation-Education at Cotterstock and LalehamQueen's eoronation-Billy, the lyyena-The Christ Church home

\section{CHAPTER II.}

\section{WINCHESTER : $1839-1844$.}

Journey to Winchester-Manners and customs of the College'Launehing'_-_To fit ti '-Tin gloves-Prefects and fags'Clnws'-Frce translations-Hills - Mouse-digging-Waterman — Rat-hunting - 'Moab'-Jackdaws-'Tunding'-Reminiscenees-Mr. Frederiek Gale-Mr. T. W. Erle-Dr. Merriman -Fev. W. Tuckwell-Rev. E. Fox-Rev. J. A. GouldWinchester Hospital-First operation-BishopMoberly's let ters

\section{CHAPTER III.}

\section{CHRIST CHURCH : $1844-1848$.}

Jenngerie in Fell's Buildings-Dean Conybeare's letter-Peminiseences-Mr. Herbert Fisher-Dr. T.iddon-Rev. R. St. John Tyrwhitt - Dr. Merriman-Mr. Walter Stanhope-Tiglath Pilcser-Jacko-Giesscn-Letters homc-Tree-frogs-Return to Gicssen-Earthquake-Red slugs B.A. degree-Private Journal . . . . . . . . . 


\section{CHAPTER IV.}

ST. GEORGE'S : 1848-1853.

Hospital patients- Extracts from Journal-Society at DeaneryMenagerie-Chloroform-Unusual delicacies-Paris-Hospital study-Souvenirs - Journal - Pendulum experiment - First article on 'Rats'-Cobra-poison-First lecture, 'The House we Live in'

\section{CHAPTER V.}

THE LIFE GUARDS : $1854-1858$.

Gazetted assistant-surgeon-Athenæum Club-Dean Gaisford's funeral -The 'Field '-Dean Buckland's death-Sale of his collections - 'Curiosities of Natural History,' first series-Journal extracts-Lecture at South Kensington Museum on Horn, Hair, and Bristles-Visit to Paris - Literary work - Bridgewater treatise-Professor Owen's letter-Lectures . . . .

\section{CHAPTER VI.}

THE LIFE GUARDS : 1859-1862.

John Hunter--Search at St. Martin's Church-Journal-Acclimatisation Society-Eland dinner-' Curiosities of Natural History,' second series-Scotland-First salmon-Society of Arts-Fish hatching commenced-Oxford and Windsor lectures-Vipcrs -Acclimatisation dinner-Giants and dwarfs .

\section{CHAPTER VII.}

FISH CULTURE : 1863-1865.

Commission in Life Guards resigned-Collection of fsh ova-Jnum:1 -Fish-hatcling at log show-Lecture at Royal Institution-Book on fisl culture-Marriage-Home in Albany StreetNew Zealanders-'Laughing jackass'-Porpoises-'Thackerar's elegy on the Porpoise-Visit to acelimatisen animals - Visit to Paris-Tront and salmon for Australia-Galway silmon and salmon ladder-Visit to Bislop Wilberforce at Lavington- 
Commencement of fish-casting-Oyster culture-Silurus-

PAGE

Fish culture at Windsor-Appointed Scientific Referee to South Kensington Museum-Commencement of Museum of fish and oyster culture

\section{CHAPTER VIII. \\ 'LAND AND WATER': 1866.}

Birth of 'Land and Water'-Salmion and church bells-Fatted snails-Fossil oysters-A fortnight's work-Collecting salmon ova at Brecon-The Yorkshire gamekeeper and the pikeLectures at Leeds, Halifax, and Bradford-Visit to a fishing weir-Fish exhibitions at Arcachon and Boulogne-British Association--Private Journal . . . . . .

\section{CHAPTER IX.}

\section{INSPECTOR OF FISHERIES : 1867.}

Koyal Commission on English Salmon Fisheries-Act of 1861Appointment of Inspectors-Frank Buckland appointed Inspector of Fisheries-First official inspection of River ExeSalmon migrations-First report-Salmon ladders-The Canterbury Stour-How to dcal with mill weirs-Inspector's mceting at Maryport-The River Ellen-Increase in sale of salmon-Museum-The big sturgeon-Casting the whaleCormorant fishing-Hedgehogs-A fortnight's fish inspection -Salmon and bull-trout jumping weirs

\section{CHAPTER X.}

ABOUT FISH, BEASTS, AND BIRDS : 1868-1869.

Sulmon and trout ova for New Zealand, Tasmania, and Australia -Horse dinner-Whelks-Bison steak-Scorpion-Dolphin at Hcrne Bay-Large Tunny-Sword-fish-Private JournalHavre Exhibition-Prescntations from Victoria and OtagoGreat Lake trout at Windsor-Scotch Fishery Act-Preservation of sea-birds-Netting the Scrpentine-Sight, smell, and hearing of deer-Domestic pets--Arslan . 


\section{CHAPTER XI.}

SCOTCH FISHERIES, AND CORRESPONDENCE : 187n-1872.

Report on Seotch salmon fisheries-Impressions of ScotlandJ'ACE

Thames salmon-Mole in Windsor Park-Wax-work showNigger, the spider-monkey-Unseasonable fish-Bull-trout in the Coquet-Fecundity of fish-Miss Swan the giantess-. The 'Two-headed Nightingale - Captain Bates the ginnt-A plea for Neweastle pigs-The Cat Show-Canterbury MuseumCrystal Palace Aquarium-Salmon at Brighton AquariumRoyal Academy without a catalogue-Puss, the blind man's dog

\section{CHAPTER XII.}

\section{THE ZOOLOGICAL GARDENS AND SEAL FISHERIES:} 1873-1874.

Duties of an inspector-Aet of 1873-Eels and elvers-Fish babies - Guy Fawkes, the young hippopotamus-Obash, the old hippo - Winter at the Gardens-'History of British Fishes'-Sea monsters-Protection for seals-Scale armour-Ross Church bells-Lectures - The old rhinoceros-Social experiences.

\section{CHAPTER XIII.}

SPECIAL INQUIRIES, NORFOLK BROADS : CRABS, LOBSTERS, AND OYSTERS, HERRING FISHERIES, \&C.: 1875-1877.

leport on Norfolk fisheries-Cromer erabs-'Natural History of Crabs and Lobsters '-Report on oyster eulture -Dynamite report-Seoteh herring fislieries-Garvie fishery-Customs on the Eden-'Log-book of a Fisherman and Zoologist'-White's 'Natural History of Selborne '-Frogs at Windsor-The Queen's visit to the Museum-Home pets: the Hag, Jemmy the suricate-Venus's slippers-Goldon beetle-Flies and blue-bottles - 'London from the 'bus-ton'-Outside the Cattle Show. . 3ng 


\section{CHAPTER XIV.}

SEA FISFERIES, BIRD MIGRATIONS, ETC. : 1878.

Report on sea fisheries-Migrations of birds in March, April, September, October, December-Design in formation of birds eggs-Strange occupations-Party in Albany Street-Frank Buckland at home . . . . . . . . 342

\section{CHAPTER XV.}

CONCLUSION : $1879-1880$.

Salmon egg-colleeting for the last time-Packing eggs in iceBeginning of illness-Fishermeu's prizes - Salmon diseaseFriendly Zulus-Mr. Spencer Walpole's notes on Frank Buckland's characteristics-Christmas at the Zoo-The Red River pig - Bear cub and bears-Dentistry operations-Last Fishery Report-Berlin Fishery Exhibition-Notes on Margate-Lions and tigers-Shrimps-The large orang-outan-Centenary of whitebait-Continued literary work - Last illness and deathBequest of Museum to the nation-Rec llections of Frank Bucklund by Mr. Archibald Young and Mr. George Rooper 



\section{I F E \\ OF \\ FRANK BUCKLAND. \\ CHAPTER I. \\ CHILDHOOD, $1826-1839$.}

Francis Trevelyan Buckland-Frank Buckland, as he was generally called - was the eldest son of the Very Rev. William Buckland, D.D., Dean of Westminster, and was born on December 17, 1826, at Christ Church, Oxford, of which Cathedral his father was at that time Canon.

'I am told,' he afterwards wrote, 'that soon after my birth, my father and my godfather, the late Sir Francis Chantrey, weighed me in the kitchen scales against a leg of mutton, and that I was heavier than the joint provided for the family dinner that day. In honour of my arrival my father and Sir Francis then went into the garden and planted a birch tree. I know the taste of the twigs of that birch tree well: Sir Francis Chantrey offered to give noe a library. "What is the use of a library to a child an hour old?" said my father. "He will live to be sorry for that answer," said Sir Francis. I never got the library.

'One of my earliest offences in life was eating the end 
of a carriage candle. For this, the birch rod not being handy, my father put me into a furze-bush, and therein I did penance for ten minutes. A furze-bush does not make a pleasant lounge when only very thin summer garments äre worn.'

The birch tree has long since been cut down, though even modern education still has its thorns.

At his christening in Christ Church Cathedral, on June 28, 1827, Sir Francis Chantrey and Sir John Trevelyan stood sponsors, with his aunt Mrs. John Buckland, a sister of Dr. Arnold of Rugby.

Frank Buckland's early years are described in his mother's journal, reflecting in miniature his character in maturer life. Through life he pursued visible facts, not abstract ideas. For facts, especially of natural history, he had from childhood a most tenacious memory. At four years of age he began collecting specimens of natural history, and at seven he commenced his journal.

Most men of mark have had, it is said, remarkable mothers.

His mother, the eldest daughter of Benjamin Morland, of Abingdon, Berks, was a woman of rare intellectual accomplishment, whose scientific tastes and power of accurate drawing enabled her to share in and help forward Dean Buckland's geological pursuits.

'At two and a half years of age,' his mother wrote, 'he never forgets either pictures or people he has seen; four months ago, as well as now, he would have gone through all the natural history books in the Radcliffe Library, without making one error in miscalling a parrot, a duck, a kingfisher, an owl or a vulture.' 
When at this age he was taken to see the camelopard and kangaroos in Windsor Park, 'he ran about with the latter and the other live animals without the least fear, though he got throrvn down by them. He is a robust, sturdy child, sharp as a needle, but so volatile that I foresee some trouble in making him fix his attention.'

September 1829.-_ I can get him to learn nothing by rote, he will not give himself the trouble to do so; his mind is always at work on what he sees, and he is very impatient of doing that which is not manifest to his senses. It was in vain to attempt teaching him ba, be, bi; I was obliged to begin with Jittle words. I think he would never learn what he cannot understand.'

June 26, 1830._' He certainly is not at all premature ; his great excellence is in his disposition, and apparently very strong reasoning powers, and a most tenacious memory as to facts. He is always asking questions, and never forgets the answers he receives, if they are such as he can comprehend. If there is anything he cannot understand, or any word, he won't go on till it has been explained to him. He is always wanting to see everything made, or to know how it is done; there is no end to his questions, and he is never happy unless he sees the relations between cause and effect.'

In December 1830 his mother gave him a small cabinet, which now bears this inscription: "This is the first cabinet I ever had; my mother gave it to me when about four years old, December 1830. It is the nucleus of all my natural history work. Please take care of the poor old thing.'

About this time a clergyman travelled from Devonshire to Oxford, to bring $\mathrm{Dr}$. Buckland some 'very curious fossils.' When he produced his treasures Dr. Buckland 
called his son, who was playing in the room, 'Frankie, what are these?' 'They are the vertebræ of an ichthyosaurus,' lisped the child, who could not yet speak plain. The dumbfounded clergyman returned home crestfallen.

December 17, 1831.-His fifth birthday. 'He reads a great deal to himself such easy books as he can perfectly understand, and he has a happy knack of making himself acquainted with the contents of a book by merely turning over the pages; it seems as if he never forgot anything.'

'I well recollect,' he afterwards wrote, 'the Duke of Wellington being installed Chancellor of the University in 1834. I was then seven and a half years old. This event is the very first subject on which I made notes and began a diary. I have this diary now. The letters forming the words are "pothooks and hangers." My mother probably guided my hand in writing. The following is a copy of my first diary :-

، On Monday, June 8, 1834, the Duke of Wellington came to Oxford, and we saw him come into the quadrangle to visit the Duke of Cumberland. He is a very fine old man. The Duke of Cumberland has white moustaches and white whiskers; he was at Mr. Jelf"s.

، "On Tuesday we went to Dr. Macbride's to see the Duke of Wellington. We saw the bishops in the procession very plainly, because there were not so many people as when the Duke of Wellington went by. We could only see the feather in the Duke of Cumberland's cap.

" "On Wednesday we went to the Divinity School, where we saw all the great people, and then into the theatre, and a gentleman lifted us up to see the Duke shake bands with the gentlemen after he had made them 
Doctors. The Duke dined in our hall, and we stood on the staircase to see the procession come up. We went into the kitchen and saw a great many joints, \&c., cooking for the dinner. Some noblemen and great people came to coffee at our house.

، "On Thursday we went to see all the great people go to church.

“ "On Friday we went into the Divinity Schools, and saw the procession again.

" On Saturday the Duke's beautiful carriage came into the quadrangle, and the Duke got out to call upon the Dean. One of the chorister's asked if the harness was of gold. The coachman had a wig and cocked hat."

"A live turtle was sent down from London, to be dressed for the banquet in Christ Church Hall. My father tied a long rope round the turtle's fin, and let him have a swim in "Mercury" the ornamental water in the middle of the Christ Church "Quad," while I held the string. I recollect, too, that my father made me stand on the back of the turtle while he held me on (I was then a little fellow), and I had a ride for a few yards as it swam round and round the pond. As a treat I was allowed to assist the cook to cut off the turtle's head in the college kitchen. The head, after it was separated, nipped the finger of one of the kitchen boys who was opening the beast's mouth. This same head is now in my museum. This grand ancient kitchen is the finest and largest in England, and was erected by Cardinal Wolsey in 1528. It was the first part of the college which was finished. In it is a curious gridiron, running on four wheels: this was used for cooking whole joints prior to the introduction of spits. 
' When the Duke of Wellington was installed as chancellor, he had to put the usual questions in Latin, when a name was proposed in solemn convocation for an honorary degree. The formula is as follows:- "Placetne vobis, Doctores. Placetne vobis, Magistri." He said, "Placetne vobis, Doctǒres ; placetne vobis, Magǐstri." Shortly afterwards he had to read some Latin in which King James's name occurred. Pulling up short at the word, he turned to the Vice-Chancellor: "Mr. Vice-Chancellor, which is it_Jacŏbus or Jacōbus-Jacōbus or Jacŏbŭs?" At last he went at it with a plunge_- "Rex noster Jacǒbus primus." The shouts of the undergraduates were nerer louder or more merry.'

In the same year Frank was taken by his mothèr to Malvern. 'The children,' she wrote, 'are delighted with the donkeys and the hills, and scramble and slide to the terror of all the passengers. We went to Worcester Cathedral, a most beautiful building within. The only thing that caught Frank's attention was a ghastly figure of a lady who was starved to death, not being able to swallow from a disease in her throat, and one of the Nuneham Harcourts, a Knight Templar, in perfect preservation. We went to see the skeletion of a whale at Cheltenham. There was a tongue bone, the contrivance of which delighted Frank; it was to prevent the water going down the animal's throat, and to help him eject it.'

In 1835, Frank first visited London, the journey eacli way being accomplished in two days. The Surrey Zoological Gardens, the British Museum, and the Colosseum are described in his journal.

\rfloor$_{\text {u }}$ August 1835 he was sent to school at Cotterstcck, 
in Northamptonshire, and in 1837 was placed for two Jear's at Laleham School, near Chertsey, with his uncle, the Rev. John Buckland.

In 1838 his journal describes the Queen's coronation procession. 'June 28: We got up early, and went to Richmond Terrace, to a stand belonging to Lady Selkirk, and saw the coronation procession. There were a mile and a half of carriages, and twelve state coaches with six horses, and great fat coachmen sitting on the boxes like great toads. There were ambassadors extraordinary from every country in Europe. Marshal Soult, the French ambassador, was most applanded of all, though he had fought against the English: he had a cap all over jewels. All the state carriages were ornamented with silver; some of them had silver cornices and crowns on the tops. The Turkish ambassador's servants had great moustaches, and red caps with crescents and stars made of gold. When the Queen was crowned, a signal was given from the top of the Abbey to the artillery in St. James's Park, who fired off forty-two guns, which made a great noise. When the Queen came back she wore her crown, with the sceptre in one hand and the orb in the other. In the evening we went to see the fireworks.'

The next day they went to the Surrey Zoological Gardens, where 'Billy, the hyena, made a noise just like a baby crying.' This hyena had been sent to Dr. Buckland by Burchell, the African traveller, that his skull might be compared with those of the old dwellers in the Kirkdale Bone Cave; but his life was spared to illustrate the life of those primeval creatures, by gnawing and cracking marrow bones as they once did. For twenty-four years he lived 
in these gardens, and then his skeleton was added to the museum of the College of Surgeons, and his stuffed skin was sent to the Deanery, Westminster.

It is not, indeed, surprising that Frank Buckland's love of nature should grow with his growth, being inherited from both parents, and encouraged by every association of his youth. In his early home at Christ Church, besides the stuffed creatures which shared the hall with the rocking-horse, there were cages full of snakes, and of green frogs, in the dining-room, where the sideboard groaned under successive layers of fossils, and the candles stood on ichthyosauri's vertebræ. Guinea-pigs were often running over the table; and occasionally the pony, having trotted down the steps from the garden, would push open the dining-room door, and career round the table, with three laughing children on his back, and then, marching through the front door, and down the steps, would continue his course round Tom Quad.

In the stable yard and large wood-house were the fox, rabbits, guinea-pigs and ferrets, hawks and owls, the magpie and jackdaw, besides dogs, cats, and poultry, and in the garden was the tortoise (on whose back the children would stand to try its strength), and toads immured in various pots, to test the truth of their supposed life in rock-cells.

There were visits also to the Clarendon, where Dr. Buckland was forming the nucleus of the present Geological Museum of Oxford, and to the Ashmolean Museum, then under the wise and genial care of the brothers, John and Philip Duncan, where the children might ride 
the stuffed zebra, and knew all the animals as friends, if not yet as relations.

In suminer afternoons, after the early three o'clock dinner, Dr. Buckland would drive out Mrs. Buckland and their children, in a carriage known as the bird's-nest, to Bagley Wood, to hunt for moles and nests, or to Port Meadow to gather yellow iris and water-lilies, and fish for minnows, and often to set free a bright-hued kingfisher (they were plentiful in those days) which he had redeemed from some mischievous urchin with a sixpence. Or another day to Shotover, to dig in the quarries for oysters and gryphices; or again to Iffley, to gather snake's-heads (Fritillaria). Both father and mother were devotedly fond of flowers, and their horse stopped automatically at every nursery garden, as at every quarry.

Some of the graver Dons were perhaps a little scandalised by such vagrant proceedings, but how much happiness and wisdom were gathered in these excursions !

Dr. Buckland's discoveries in geology were indeed but slowly appreciated, and were regarded with suspicion by many. Frank Buckland used long afterwards to tell of an incredulous Don, who could not bring his mind to believe in the scientific facts which Dr. Buckland was just then bringing to light, and who boldly asserted that a mammoth tooth dug up in St. Giles's parish, just opposite to Str. John's College, was nothing more nor less than the tooth of an elephant which had died in Wombwell's menagerie at some unknown antecedent period! 


\section{CHAPTER II.}

WINCHESTER, $1839-1844$.

In July 1839, Frank Buckland, then twelve years old, was elected scholar of Winchester College, Dr. Moberly, the present Bishop of Salisbury, being head master.

His life at Winchester is best described in his own words :-

'It is now thirty-three years ago,' he wrote in 1873 in the 'Temple Bar Magazine,' ' since, a frightened and trembling lad, in the month of August 1839, I found myself standing underneath the gateway of William of Wykeham's noble college at Winchester, duly entered as a scholar thereof by the nomination of Dr. Shuttleworth, then Warden of New College, Oxford, afterwards Bishop of Chichester. In those days there was no railway to Winchester, and I went from Oxford to Winchester in a four-horse coach, the driver of which wore most wonderful top-boots and a marvellous coat with gigantic buttons. I had great respect for this coachman, as he once brought my father a semi-dead crocodile, in the coach boot, from Southampton. My father turned the dead crocodile into the pond in the middle of the quadrangle at Christ Church, to revive him; but he refused to be revived, so I rode about upon him, Waterton fashion, and somehow I always 
associated the Southampton coachman with a crocodile. I recollect perfectly well that he once told me he had driven my mother to school to Southampton, and this made me think him very old. Soon after we had driven over Folly Bridge on our road to Winchester, crossing the Thames at Oxford, and were ascending the Bagley Wood Hill on the Abingdon Road, the rest of the passenger's began to complain about a nasty unpleasant smell, which apparently proceeded from the luggage on the top of the coach. A bluebottle fly first appeared from out of Bagley Wood, then another, until a perfect swarm of flies soon followed the coach, hovering and buzzing over the luggage. The passengers were mostly Oxford boys, going to Winchester, and there was a strong idea among thern that somehow or other $I$ knew from whence this odour proceeded. I knew perfectly well the cause of the smell, but I said nothing. The "governor," then Canon of Christ Church, had kept a haunch of venison for me to take as a present to the head master, Dr. Moberly; he had kept it so long hanging up in the larder at Christ Church that it had become very " exalted" indeed; nevertheless he packed it up, thinking to make it last anyhow as far as Winchester. His experiment failed, and the other boys punched my head on the top of the coach, and were very near throwing me and my venison overboard altogether.

'We Oxford lads arriving at Winchester', all went down to the college together, and put on our gowns for the first time. Our gowns were made of cloth, the like of which I never since beheld, and our hats were taken away, as no Winchester boys, except prafects, wear hats. It is rare to 
find a Winchester man now with a bald head, and even now I never wear a hat if I can possibly help it.

' Immediately after chapel the old stager boys all came round the new arrivals to examine and criticise them. I perfectly recollect one boy, $\mathrm{H}-$, to whose special care my poor confiding mother had entrusted her innocent unsuspecting cub, coming up to me with a most solemn face, and asking me if I had brought with me my copy of the school book "Pempe moron proteron." I said I had not. "Then," says he, "you must borrow one at once, or the Doctor," i.e. Dr. Moberly, the head master, "will be sure to flog you to-morrow morning, and your college tutor, one of the præfects, will also lick you." So he sent me to another boy, who said he had lent his "Pempe moron proteron," but he passed me on to a third, he on to a fourth: so I was running about all over the college till quite late, in a most terrible panic of mind, till at last a good-natured præfect said, "Construe it, you little fool." I had never thought of this before. I saw it directly: Pempe (send) moron (a fool) proteron (further). So the title of this wonderful book after all was "Send a fool further." I then went to complain to H__; he only laughed, and shied a Donnegan's Lexicon at my head. Idodged it like a bird, so he made me pick it up and bring it to him again, like a retriever dog. I then had to "run for another shot," and he winged me this time; so I shall never forget the translation of Pempe moron pioteron.

"The beds in "chambers" (as the sleeping apartments are called) are, I believe, as old as William of Wykeham himself; they are made of very thick oak planks, and there is a hollow for the bedclothes, after the style of the beds for 
foxhounds in kennels. I was glad enough to turn in after this long and anxious day. I dreamed of home, and calculated how big some young ducks I had left in the outlouse at home would be when the holidays came round. They were my ducks. I had bought them as "squeakers" on Port Meadow, with my pocket-money, and my father had promised that if $I$ was a good boy at my lessons I should cut their heads off when I came home, on the wood block in the tool-house, with the gardener's hatchet. It was made a great treat to my brother and myself to cut a duck's head off while my dear old father held the duck's legs-but he was not dressed for the occasion in his canonical robes.

' In the midst of my dreams I imagined that an eruption of Mount Vesuvius had suddenly taken place. I felt myself flying through the air, and then experienced a most tremendous crack on the back of my head; in fact, I was "launched." I afterwards ascertained that all new boys were "launched" the first night after arrival. The process of "launching" is in this wise: when the innocent is fast asleep, dreaming of home and mother, two boys catch hold of one side of the bottom of the mattress and two of the other, and at the signal "Launch!" run the bed out in the middle of the room with the boy in it; they then cut away like rabbits to their own beds, while the wretched "junior" lias to rearrange his bed as well as he can, and tumble in again, frightened ont of his wits. There is, however, a little mercy shown, for it is considered unfair to launch the same boy twice in the same night, particularly as he has, in the course of a day or two, when he is beginning to be able to sleep again (for "launching" made 
me sleep with one eye open), to be initiated into another college mystery.

'A few nights afterwards I dreamt I was wandering on the sea-shore, and that a crab was pinching my foot. Instantly awakening, I experienced a most frightful pain in my great toe. I bore it for a while, until at last it became so intense that I had to jump up with a howl of agony; all was quiet, but the pull continued, and I had to follow my toe and outstretched leg out of bed. I then found a bit of wetted whipcord tight round it; but the whipcord was so ingeniously twisted among the beds that it was impossible to find out who had pulled it. I returned to bed as savage as a wounded animal. The moment I was settled, the boys all burst into a shout: "Toe fit tied! By Jove, what a lark!" This barbarous process is called "toe fit tie" because there is a line in Prosody which begins, "To fit ti, ut verto verti." Hence the origin of this Winchester custom.

"The latest arrival in college is called "junior in chambers," and in my time "junior in chambers" had a precious hard time of it. He had to get up at "first peal," i.e. when the chapel bell rang-and this was awfully early in the morning - call all the boys in the room, light the fire, put out the prafects' washing apparatus, \&c. The Winchester fires were large fagots burnt upon "dogirons." It requires great art to make a fagot light quickly, and the burning sticks were awkward to handle. No tongs were allowed; so when a boy first took office he had a pair of "tin gloves" given him; i.e. one of the seniors took the red-hot end of a bit of stick, and blowing it to keep it alight made a mark down all the 
fingers and round the wrists; after he had received his " tin gloves" woe be to the boy who managed the fagots clumsily, for he instantly was formally presented with another pair of "tin gloves." The "junior in chambers" had also to clean the wash-hand basins, and they were only cleaned before chapel-time on a Sunday morning. We had to do this out in the open, at two water-taps, which were called "conduit." I'll be bound to say that very few Winchester boys now know how to clean basins properly. The secret is to use salt. But "cleaning basins" was terrifically cold work for our fingers on frosty mornings, especially if we had chapped hands; and what with "tin gloves" and salt, this was often the case. We also had to mark the basins. I wonder if any of my readers know how to mark indelibly a common white wash-hand basin with initials of the owner? Well, it is a Winchester secret. If you rub the basin hard with the pipe part of an ordinary drawer key, you will wear off the white enamel of the basin and lay bare the brown part of the structure. One boy, F_- now a judge in India, was wonderfully clever at marking basins. He used to be let off cricket to mark basins, and he used to sit by the "tap " working away at the basins, like a cobbler. How I envied him ! For I even now hate cricket. I had quite enough of it as a fag at Winchester. The "junior in chambers" had also to clean the knives. There were no American knife-cleaners in those days; but we cleaned the knives by rubbing them up and down quickly in the cracks between the stones of the college court. I could now walk to my favourite knife-cleaning place just by the college chapel door; it is on the west side. 
"It was also the duty of "junior in chambers," as well as other "fags," to make coffee for the præfects. There is a great art in making coffee. The coffee must be mixed with cold water, it must then be put on the "dog-irons" till large bubbles come to the surface; these must be broken one by one with a piece of stick; a piece of the skin of a sole must then be put into the coffee, it must be allowed to boil up again, and then a small cup of cold water thrown in and the coffee allowed to settle. The juniors used to take pride in making coffee, and I recollect once, when there was a "coffee match" I got the second prize, and will now back myself to make coffee against anybody, even professed cooks. We used also to make plum puddings; but we never began them till very late at night, when we thought the master, Dr. Wordsworth (now Bishop of St. Andrews), had gone to bed and would not come his rounds that night. I used to roll the dough with the towel roller that was behind the door. The biggest licking I ever got in my life was for making a heavy plum pudding; and to this day I would not undertake to make a plum pudding, as I shall never forget that licking.

'The præfects, when not particularly busy with their books, instituted bolstering matches among the juniors. A bolster, properly arranged, is a very formidable weapon, and the great object was to skin one's adversary's nose. This is done by a well-directed blow which brings the rough edge of the bolster on to the bridge of the nose. I recollect on one occasion having a fierce battle with a lar who has since died, holding a high official appointment. In the middle of the fight we heard a key put in the door. 
Br Jove! it was Dr. Wordswortl, coming the rounds ! I was into bed in a moment, and, though panting like a liunted fox, pretended to be fast asleep. Dr. Wordsworth put the light of the lantern he carried right into my eyes, but I never moved a muscle, because I knew perfectly well that if I had been caught my name would have been "ordered" for a flogging the next morning, while I slould most certainly have got a "tunding" with a ground-ash stick from the præfects for being such a fool as to be caught by the master.

"I had not been long at Winchester before I was appointed to be "rod maker." The rods consist of four apple twigs; these are tied fast into four grooves at the top of a light wooden handle. It requires some skill to make a rod properly, as the twigs are apt to shift round under the string, and thus get loose; and if a rod were not properly made, and if it broke when the master was using it, I think the manufacturer was entitled to one cut from a rod made by some one else. The præfects used to buy the ground-ashes from Bill Purvis, the under cook. They were sapling ashes, with the roots on. The legend was that Purvis used to boil them with the mutton to get the grease into them, and then put them up the big college chimney to toughen; and, by Jove! they were toughl as whalebone!

"Unless a boy had twenty juniors, i.e. twenty bors below him in the school, he was not allowed to "think." 'T'he præfects, when they wanted anything, used to cry "Junior! junior!" and the junior boy in the school had to run instantly. 'The prrefect would say, "Where is so-andso ?" The junior would answer, "] lease, I thouyht so-nni- 
so." "Have you got twenty juniors?" "No." "Then you must have three clows for thinking." "Clows" are boxes on the ear; they don't hurt much; we boys found out the proper way to shift one's head, so that the clows should not hurt.

'Altogether, we juniors had a pretty hard time of it; but it was wonderful good training; it made one so awfully sharp and certain about little things. The edict agaiust "thinking" was good; it made one find out for certain, or else say "I don't know." We were never whacked for " not knowing," only for " thinking." Many people about are always "thinking;" they should have been at Winchester. A few "clows" administered to them when juniors would have done them much good.

'I once made a tremendously lucky hit. I was very nearly at the bottom of a class before Dr. Wordsworth. A senior boy was construing a passage in the first Georgic, describing a man rowing up stream with oars:

Non aliter quam qui adverso vix flumine lembum

Remigiis subigit : si brachia forte remisit,

Atque illum in præceps prono rapit alveus amni.

None of the boys could construe the word "atque." The ordinary meaning of "atque" is "and." I thought to myself, if I left off rowing when pulling against stream, it is common sense that the boat would immediately carry me down stream. I was a loug way down the class, and when my turn came to answer as to what was the English of atque, I jumped up boldly and sung out, "Atque, immediately." "Gcod boy," sand Dr. Wordsworth, "take their" places;" and if I recollect right I took twenty-two places 
at one leap, and marched in trimmph from the bottom to within two of the top of the class. I have a strong idea that when school-hour came I got a licking from two or three boys for knowing what the English of atque was. There was one consolation, however. The next day I was set on in Dr. Wordsworth's new edition of the Greek grammar, of which he was especially fond, but which we boys, who knew the old Greek grammar pretty well, hated with all our hearts. I had to interpret something connected with the formation of the aorists of some horrible Greek verb. I never could understand Greek grammar, and I never. shall, knowing nothing about these aorists, preterplnperfects, and things of that kind. So Wordsworth's Greek grammar atque -immediately - sunk me, like a stone round my neck, to my old position at the bottom of the class, and, if I recollect right, two places lower than whence I started.

'We boys were very fond of recording maltranslations. I recollect one of my own. Dr. Moberly had "put me on " to translate a passage which I confess I had never looked at. I was pulled up short at the words "Numinis Idcei," which onght to mean " of the god of Ida." I translated it " of the Numidean Ideus." I also recollect one boy, whose name was Salmon - of course I cannot forget that nametranslating-

Aspice bis senos lætantes agmine cyonos ( $E$ in. i. 393), which ought to be "behold twice six swans." He trinlslated it "Behold two old swans." The following trusslation is also a legend among Winchester bays :-

Silvestrem tenui mugazn meditaris avenú (Ecl. i. 2). 
which being properly interpreted would read as follows: "Meditaris, thou art playing; silvestrem musam, a rustic song; tenui aven $\hat{a}$, on your slender flute." The following very different version, however, was given by the unfortunate boy, thus: "Tenui, I held; silvestrem musam, my woody muse; meditaris arenâ, on the shores of the Mediterranean." Other maltranslations, from the records of public schools, are given in that admirable little book, "The Art of Pluck." "Et tu Brute," "You brute, you." "Muli ducis avi domum," which ought to be "Thou art taking her" (Helen) "home under bad auspices," was rendered thus: "Thou bringest apples to the house of thy grandfather." "Ite, capelloe," "Go it, Jou cripples." "Terr" mutat vices," "The Earth changes her shift." The author of "The Art of Pluck" then proceeds to observe, "From which examples is seen, first, how simple words, which cannot be construed wrong so far as grammar concerneth. may yet be turned by fit attention to a wrong meaning; how, secondly, a complex sentence so turned to a wrong meaning may yet be further improved in wrongness br bad grammar, as happened with Mr. Thomas __ , of College, who, when he had construed 'Hannibal Alpes transivit summâ diligentîa,' 'Hannibal passed over the Alps on the top of a diligence,' was strajghtway reproved br the examiner as having construed wrong; whereon he ret improved the wrongness by bad grammar, construing thus : "The Alps passed over Haunibal on the top of a diligence; and again, by worse grammar, 'A diligence passed over' Hannibal on the top of the Alps." I Inly recollect nne Greek maltranslation. It was this : каi $\varepsilon^{\prime} \xi \varepsilon \lambda \theta \dot{\omega} \nu \varepsilon^{\prime} \xi \omega \dot{0}$

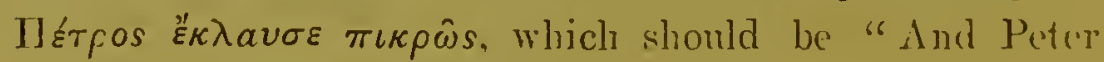


went out and wept bitterly." The undergraduate, whose brain was crammed by the coach to the utmost, translated it "And Peter went out and slammed the door violently." I have lately heard one in Portuguese that really took place. A certain lad received extra pay on board ship as being a great linguist. The ship was disabled, and put irto a Portuguese harbour with a broken mast. The interpreter did not know a word of Portuguese, and was puzzled how to get out of the mess. Some one said, "All right; all you have to do is to speak English and put an 'o' at the end of every word." So when the Portuguese ship carpenter came on board, the interpreter boldly went up to him and said, "Look-o here-o, we-o want-o new-o mast-o ship-o." The puzzled carpenter answered, "Non intendi," i.e. "I don't understand." The captain roared out to the interpreter, "What does he say?" The interpreter very sharply answered, "Oh, he says you can't have it under ten days." "Oh, confound him!" said the captain, "that won't do for me. What fools these Portuguese are!"

"The passenger by the train from Winchester to Southampton, if he looks out of the window just as he passes Winchester station, will see a hill on the downs, surrounded by a ditch and a valley and a rampart. This is St. Catherine's Hill, or, as we boys called it, "Hills." At certain seasons of the year we were marched on to these hills before breakfast. The custom was to keep line, while the prefect of Hall "whipped in" with a ground-ash as we ascended the hill. When we got within the remains of the old earth fortification which forms a kind of crown to the hill, we broke up. Many of the boys played football or cricket. l'or my own part, I never did either; my 
great delight was to dig out field mice, and at that time there were a great lot of field mice on "Hills." They make long burrows through the turf of the downs, and then into the chalk itself. There are certain signs by which the experienced "mouse-digger" can tell whether the mouse is in the hole or not, but, for the benefit of the little mice, I shall not give the present Winchester boys this knowledge: let them acquire it for themselves. Having discovered a hole with a mouse in it, the next process is to pass down it a flexible stick, and this showed where the hole had taken a turn. We then dug down to this turn, and passing the stick further up the burrow, dug down to it again. In about three diggings 1 generally managed to gret the mouse, but the last part of these engineering operations had to be conducted with very great care, as the mouse generally made a bolt for it. Little pickaxes used to be sold at a certain shop in Winchester; we called these " mouse-diggers." During the holidays I was initiated into the noble art of fox-hunting by my uncle, 'Tliomas Morland, who kept the Berkshire hounds at s'lleepstead, near Abingdon. He was then very particular about having the fox earths stopped. Acting, therefore, upon my experience in the matter, I took very good care to stop all the mouse earths that were within a reasonable distance of the one on which I was operating. 'The consequence of this and other precautions was, that I was looked up to by the other boys as the most experienced mouse-digger in the college. I also tried to set the fashion of eating these field mice as we caught them. On some mornings we were fearfully hungry on the top of these hills (we went there before breakfast). I used to 
skin the mice, run a bit of stick through them, and roast them in front of a fire which I made out of sticks collected from a fence which divided "Hills" frum a ploughed field. 'This hedge belonged to one Farmer Bridger, who complained to the warden about our burning his hedge, so I had to take the mice home and cook them in college. A roast field mouse-not a house mouse--is a splendid bonne lowe for a hungry boy; it eats like a lark. Mice cooked in college were not nearly so good as mice cooked on "Hills."

'The præfects, that is the senior boys, were not required to go on the hill; they were allowed to wander about the water-meadows below; and each præfect was permitted to be accompanied by the junior boy he chose to invite. Now, I wis then a good hand at trapping and snaring anything, and it soon got about that I knew how to wire trout. My skill was put to the test, and after that I very. seldom went on the hill again-which I regretted, because I was fond of mouse-digging-as I had to wire trout for the præfects' breakfasts. 'The guardian of these meadows was a funny old fellow, who lived in a wretched cabin close by a certain weir, and we boys knew him as "Waterman." When, therefore, we started on our trouting expeditions, the first thing to do was to send out scouts to "mark down" Waterman, and generally a decoy party was sent out without any wires; their duty was to poke about and pretend to look for trout, while myself and the real poachers were at work quite in an opposite direction. The wires I used were the finest pianoforte wires, and there is great art in making the noose and passing it over the trout's head. We did not do much harm after all, for the 
water was so clear and the trout so artful, that we never canght very many. "Waterman," though, once very nearly caught me; but I gave him a tremendous chase across the meadows and through the various watercourses, and ultimately had to swim the river to get away from him. The sleeves of our college gowns acted as pockets, and I had two trout in one sleeve and one in another. When swimming the river the fish in my sleeves came to life again, and I had a hard job to land myself and my fish.

'Rat-hunting was a celebrated sport of us boys. Therè was a mill which adjoined our playground, which we called "Meads." The miller used to catch the rats in the mill and let them down in a round wire rat-trap (how well I recollect that trap !) out of a little porthole window in the mill, by means of a string. We then turned the rats out one at a time in the middle of the cricket-ground, and gave them a due amount of law; when they got their proper distance "the hounds" were laid on. "The hounds" were not allowed to use sticks or stones, but had to catch the rat by the tail - a very difficult operation, I can assure you, and the rats bite fearfully if you do not know how to handle them. You should twist them round and round the moment you get a hold on the tail. If a rat showed particularly good sport he was kept to hunt again on an off day when the miller had no rats.

"I was also, I am sorry to say, very fond of wiring cats. There was a grating in a certain iron door named "Moab." (The reader must know that "Moab" was the place where some marble basins and washing accommodation lad been erected for the use of the boys; we christened it Moab on account of the passage, "Moab is my wash-pot.") The cats 
used to come through the grating at "Moab" gate, but they were very artful, and used to push the wires on one side. The first cat I caught was the "sick-house" cat. Now "sick-house" was the hospital for the boys, and "Mother" was the kind-hearted old matron who looked after it. Of course I let "Mother's" cat go free, and " Mother" never found me out, though I think she always suspected me.

There were a great many jackdaws in the college tower. The bell-ringer's name was "Dungee;" the under porter's, "Joel :" college porters from time immemorial at Winchester have been called by the names of the minor prophets in succession. Dungee and Joel taught me to ring bells, and I was very fond of going to assist. When the young jackdaws were fit to take, Dungee, Joel, and myself used to collect them out of the holes in the tower. Ve reared them and let them fly when they were properly fledged. The mother jackdaws used frequently to come to feed their young when we boys were in school at lessons. We used to get up early in the morning to catch lobworms to feed the jackdaws. I frequently tried a plan to catch the Winchester rooks. It is this: roll up a piece of brown paper in the shape of a cone, place a piece of cheese at the far end of it, then put plenty of birdlime or pitch inside; the bird puts his head into the cone, the birdlime sticks to his feathers, he attempts to fly, and tumbles about in a ridiculous manner. I confess I was not very successful at this fun; the Winchester rooks seemed to have imbibed some of the learning of the place.

'Though we were very fond of rat-hunting and mousedigging, yet we did not have much to do with fire-arms. 
When dining iast year at the regular Wykehamist dinner an old brother Wykehamist told me that he well recollected in his time that Dr. Gabell once suddenly called upon all the boys to parade their Ainsworth's dictionaries. One lad brought up his dictionary with fear and trembling. Dr. Gabell found it would not open; he therefore made the boy open it, when it was discovered that the leaves had been beautifully glued together, and it had been converted into a case for a brace of pistols. This same boy's "scob" (or school box) was then searched, and instead of the proper amount of classical books that should have been there, the Doctor found a brace of live ferrets eating a fowl's head.

"A great deal has been said and written about the cruelty of "fagging," and more especially of "tunding," at Winchester. As in almost every case under dispute, there are two ways of looking at this matter. Kept within bounds, "tunding" is an excellent institution, but of course may be sometimes very much abused, particularly if the præfect happen to have a bad temper. The boys of this generation would be a great deal better for a little judicious "tunding." I lately had a page boy who could work well if he liked; one day, after a series of omissions, such as not cleaning the monkeys' night cage when they were in their day cage -not feeding the parrot-omitting to brush clothesboots not ready - the room where I cast fish left untidy, \&c., always "thinking" (see my definition of thinking above)_I called him up and said, "Now, John, I'm going to give you a present of fifty pounds." The boy's face brightened up, and he said, "Oh, thank you, sir." "It's not in money, though, John," said I. "I'm going to give 
you a jolly good hiding, and that will be worth fifty pounds to you."

'All I can say in concluding these remarks is, that the jolly good hidings and the severe fagging I got as a lad at Winchester have been of the utmost value to me in after life, and therefore I should be very sorry to see " fagging" and "tunding" altogether done away with at Winchester. God bless the dear old place, and all Wykehamists, past, present, and future.'

At Winchester Frank Buckland made many lifelong friends, who yet retain a vivid recollection of his school life, and from some of them the following reminiscences are gathered :-

'Imagine a short, quick-eyed little boy, with a shock head of reddish brown hair (not much amenable to a hairbrush), a white neck-cloth tied like a piece of rope with no particular bow, and his bands sticking out under either ear as fancy pleased him-in fact, a boy utterly indifferent to personal appearance, but good-tempered and eccentric, with a small museum in his sleeve or cupboard, sometimes a snake, or a pet mouse, or a guinea-pig, or even a hedgehog. In the summer he would be always in the hedgerows after birds, weasels, or mice, or in the water-meadows after crayfish, tomculls, and other fish which hide under stones. He was known as an expert hand in skinning badgers, rats, \&c., and also setting wires at Blue-Gate for cats; old Purver, a college servant, used to find them early in the morning when he went through into school to light the fires. In fact, he was a born naturalist.' '

'I remember,' another schoolfellow writes, ${ }^{2}$ 'sleeping 'Mr. Frederick Gale.

2 Mr. T. W. Erle. 
next bed to him for six months in "Third Chamber;" he used to get up in the middle of the night, and designedly in half-darkness carefully bind two fagot sticks together, for the purpose, as he said, of accustoming himself to be called up as a surgeon, half asleep, to do some professional duty under adverse circumstances. I remember his starting a diary, and at the same time a hedgehog. The diary remained in abeyance, and the hedgehog was always being lost. So I undertook the diary, and it consisted of "lost hedgehog," "found hedgelog:" and so on on alternate days, till at last there came the final and fatal entry of "ate hedgehog!" We messed at what was called the same "end," that is to say, we dined at the end of the same table, and the hedgehog was one of the strange things which sometimes appeared at the table there.

' One day he caught a young' adder, and removed the poison fangs, after which he lent or gave it to me, and it lived inside my college waistcoat for a long time. He dissected a series of cats; and when the warden's mastiff died, I remember his dissecting the eye: my first knowledge of eyes, which is now pretty good, dates from that, occurrence.'

The raid on the cats was begun in defence of certain rabbits, kept by some college boys, which, though technically illegal, were winked at by the authorities. The labbits had suffered sad depredations at the claws of it cat, and it was determined to defend the roak, and punish the invader, which was speedily wired, and the following afternoon was devoted to the skinning of it. Many other cats after this shared the like fate, including a large black 
and white tomcat of Dr. Moberly's, brought in with triumph; his skin was a treasure. The fellows in Frank's college cliamber were much exercised by a very offensive and persistent odour in the room, and on investigation it was traced to the box under his bed, where were discovered the remains of a cat, which he had for some time been in the habit of dissecting member by member on the slr in bed, and, as the operation lasted a considerable time, the complaint of an ill odour was not unfounded.

The skinning of his specimens used to take place in Moab; and the doors of the lockers there, both inside and out, were adorned witl the skins of cats, rats, mice, bats, et hoc genus omne, duly peppered to prevent smell. His maceration pots at Amen Corner, with heads of hares, rabbits, cats, \&c., being reduced to skulls, were things to be avoided.

'Frank and I,' writes another,', 'were always great friends; for though the distance between a junior in chambers and a præfect in full power was rather a wide one, yet a community of tastes brought us together. I remember that, at one time, an exposition of cooking came on my fellow-præfect and myself in Sixth Chamber. Ve used to make apple dumplings with, as may be supposed, the heaviest of all possible paste, and boil them at about twelve o'clock at night, tied in a neck-cloth! Frank would always volunteer his neck-cloth, which was unstarched, and used to beg to be called when the dumplings "came off." Many a time have I seen him sitting up in bed eating the proceeds of our cookery, which I own 
we the cooks had too much regard for our digestion to attempt.

'Frank, too, set up a sort of amateur dispensary or hospital. He had a patient or two. One man I remember, with a bad hand, who used to come down to College Gate at twelve o'clock to consult him and be experimented upon. In his toys (cupboard) he had various bottles and specimens, one very highly treasured possession being a three-legged chicken.

'His own natural disposition was of the sweetest and gentlest. I never saw him in a passion, though he used to get a good deal teased at one time for his untidiness. But he always had a bright smile amidst it all, and was ready to do anything for anybody immediately after. One thing used to strike me very much about him, and that was his exceeding love for his mother. Boys are generally reticent upon this point, but Frank seemed never tired of telling me about his, and how much he owed her.'

'Good-humoured, full of spirits, uniformly amiable and obliging,' writes another old schoolfellow,' 'Old Buckland, or Fat Buckland, as he was usually called, became the most popular boy in the school; every one brightened into amusement at the sound of his lond voice and merry laugh, and the tremendous "view halloa" which preceded and announced his coming.'

Fond of school work he was not, but he did his duty fairly, got through his 'construes' somehow, and ground the regulation grist of dreary Greek and Latin verse. Neither did he care for games. Already his naturalist pursuits absorbed him. He did not so much regard the

' Rev. W. Tuckwell. 
chalk fossils which abound in the Winchester hills; he had no microscope, neither was he a collector of insects. His delight was to study the habits of live animals, and to examine their structure when dead. An owl, a buzzard, and a raccoon were successive tenants of one of his lockers. A whole regiment of tame jackdaws owned him as their patron, headed by an evil-looking magpie, with a name not mentionable to ears polite, all of whom he used to feed twice a day with bread and milk from 'sick-house.' His hedgehogs kept open a perpetual fosse at the base of the wall bounding the college meads, and a good deal of agility was generated one day by Frank's appearance in the schoolroom at the crowded moment, just before the entrance of the master, brandishing a bottle of ammonia, and proclaining that the viper had got loose. He was a dexterous taxidermist, and might be seen on a halfholiday in the deserted 'Moab' or lavatory, plying his scalpel, and surrounded by a smell of corrosive sublimate, the subjects being cats, bats, which nested in a hollow plane tree in the meads; and moles, of whose skins he constructed a very comfortable waistcoat. The flayed bodies of the smaller creatures were sometimes eaten; squirrel pie, and mice cooked in batter, ranking as special dainties; oftener tied up in gallipots, and buried in the mud of a villanous puddle, called Log Pond, till the flesh fell from the bones, and it became easy to articulate the skeleton. 'Towards the end of his school days his anatomical studies enlarged their scope ; gruesome fragments of humanity were conveyed secretly from the hospital, and as secretly dissected. He came to look on his schoolfellows with a professional eye. One $\mathrm{R} \longrightarrow$, a boy with it 
dolicocephalous head, used to relate with a slight shiver that he had overheard Buckland muttering to himself, 'What wouldn't I give for that fellow's skull!'

It was a rare treat to walk with him in the beautiful water-meadows of the Itchen, into which on summer evenings the bounds of school imprisonment were extended. He knew every bird in the hedges, every snake, shrew, or water-rat in the banks, every eel and crasfisht in the pleasant streams of 'Simmonds,' and 'Old Barge.' and 'Adam and Eve,' and 'Waterman's Hut,' and had a thousand anecdotes to tell of them. Reserved with the boys in general, who looked upon him and his hobbr as an amusing enigma, he bestowed all his enthusiasm on those who could understand and share it. If his naturalist ardour marked him off from ordinary boys, so also did his unfailing kindness and cordiality to all around him. Probably no one of his schoolfellows can recall, in thinking of him, an ill-natured utterance or an oppressive deed during all his years at Winchester. Very many recollect with gratitude acts of quiet friendship and words of goodhumoured counsel, which came with double force from one so simple and so modest, yet who lired so eridently a life high-principled and blameless.

'It was during my last two years with him at Winchester,' writes another, ' 'that we were most together. He was my pupil at his own request (as was also his brother), and the last year was with me in Third Chamber. During that time we were constant companions; when we went to "Hills" he generally came "off" witl me, and we spent our time in the water-meadows, or in the chalk 1 Rev. E. Fox. 
quarries. The river was not unfrequently the last home of a dead dog or cat; and, whenever it was possible, the carcase was rescued and decapitated, the head being carried home to College in his handkerchief. This was dissected most carefully, each bone by itself-a process which was not very sweet to the olfactory nerves; and then came the question where to bestow the treasures. In the locker? they were soon emptied by the owner of the next locker; they were buried, but the cats dug them up; they were placed in a basin of water under his bed; the bedmaker threw them into the fire. At last, however, a safe stowage place was found. Frank made friends with the bell-ringer, and was permitted to carry skulls, bones, and muscles up to the top of the Chapel tower. Here, exposed to air, sun, and rain, in due season they were bleached, and then, when warranted sweet, they were brought down and ranged in order at the head of his bed in Third Chamber. The bed became quite a lion; warden, master, and porter often took visitors into the chamber to see the strange medley of animal remains there exhibited.

'As a senior he was very kind to his juniors, even to giving them an occasional dose of medicine, and his remedies were certainly effectual though sometimes severe.

"A box on the ear, commonly in Winchester language called a "clow," always excited his indignation. "It's a shame," he used to say, "and may hurt a boy for ever. Take a ground-ash and use it on the proper place, that will do no harm and all the good in the world; " but I think he was too kind to have ever used it himself on anyone.'

'Frank and I,' writes another,' 'were at Winchester

$'$ Rev. J. A. Gould? 
together, where wo were always fast friends. In school hours he was a painstaking and conscientious worker, never learning his lessons or preparing his task quicker or better than when he had some pet, a dormouse or sometimes a snake, twisting and wriggling inside his callege waistcoat, which, having found its way out at his boots, would be carefully replaced under the waistcoat to go through the same journey again.

'We were both of us lucky in having some good præfect friends. It was a præfect's privilege to call off two or three boys to ramble with him, in the water meads or elsewhere, instead of going with the less fortunate others to the top of Mons Catherina. It was here, amidst the ditches and trout streams by which the meads were intersected, that Frank was in his glory. Here he would spend his whole time, watching with keenest interest the habits of the waterbeetles, or the development of tadpoles and caddis-flies, or the antics of some favourite old water-rat. Not that the Waterman (the occupant, i.e. of Waterman's Hut, a much frequented place of resort in those days) was always pleased to see his genial face. Well did the Waterman know that concealed in the sleeve of Frank's college gown was a deftly twisted wire, and in his waistcoat pocket a string; which he always kept there, with a knife and a sixpence, having been advised to that effect (as he once told me) by his godfather, and which would soon be extracted for the purpose of attaching the wire to the end of a willow or ash stick; and should a big trout have gone up one of those side ditches for quiet and repose, the same big trout would in a few seconds be transferred to the bank and be lost to him for" over. "What's the matter"? "I said to him one day, as I 
saw him looking very cross and most anxiously surveying the watery territory of which he was the deputy warden.

" "What's the matter?" (he answered gruffy); "why, there's that young Buckland about, isn't there? and there's no keeping no fish nor nuffin' from him." '

It was while at Winchester that Frank first set his heart on becoming a surgeon. He chose as a parting gif from one of his tutors (in lieu of Goldsmith's poems or such like book) 'Graham's Domestic Medicine,' and studied it attentively. One of his favourite ways of spending his holiday during the latter part of his stay was in going to the hospital, of which he wrote home in 1843 as follows :-

'We had leave out last Monday. I went with Mr. Butler over the Winchester Hospital, and was very much amused. We saw sundry fractures in all parts of the human body. I could not see any operation, but I shall go over again, I think next Tuesday. I think I would like to be a surgeon above all things, and to have the management of all these sharp knives and broken limbs, eyes, \&c., if I understood it all.

'Mother (the matron at the sick-house) asked me to kill her cat on Tuesday, which I did by a blow on the neck; she was nearly dead because she had gone away and stayed without food for some time, and Mother could not make her eat; I skinned her and put her body in chloride of lime, but the flesh would not come off as I wanted it, so I cut off her skull and boiled it for three hours, and it is now beautifully white and clean. The warden's large mastiff was shot the other day because it had got the distemper. I got the warden's boy to get me the head: I was very hard at work yesterlay cleaning it, i.e. cutting the flesh off; I 
am going to get it boiled, and then it will be fit to keep : it will make a beautiful skull, I think.

' We had leare out last Tuesday, and I went up to the hospital again, where I met $\mathrm{Mr}$. Paul the house-surgeon. I walked through some of the wards, and saw the same legs and arms in bandages and splints which I saw last week broken and not yet set. I did not see many cases, because I went directly into the operating theatre, where an amputation had been performed that morning: the leg was lying on the table, so I immediately pulled out my pocketknife and began dissecting it. It had been amputated just above the knee. It was just like a leg of beef with yellow fat, \&c., and I daresay it would have disgusted you if jou had not been accustomed to dissection. However, I cut away some of the bottom of the foot to look at some muscles, and then I cut off a great piece of skin; I put it in my handkerchief, and took it down to the tanner's to be tanned. The man there turned it about, but could not find out what it was. I shall have it back next Tuesday. I hope tanned like ox-leather. It is very thick, thicker than you would expect. Mr. Paul laughed at me for skinning the leg, and particularly when I pocketed the skin. I told the tanner it was the hide of a curious animal (which is true). The boys in College were very much disgusted at iny exploits, nevertheless I have had applications made for skin. I shall bring a good piece home with me. Could you manage to send nie a lancet by post?'

With the lancet when it arrived he practised bleeding on those of his companions who were courageous enough to allow themselves to bo operated on, offering sixpence as an inclucement. 
The Christmas vacation of 1843 was spent as usual at Christ Church, Oxford. At this date there is the following entry in his Journal, which he had begun to keep regularly in $1842:-$

'Father gave me a collection of bones. Round Oxford Infirmary with Dr. Wootton; fainted at my first operation, an amputation by Wingfield; but I had been up all night at Abingdon ball.'

In July 1844 he left Winchester for Christ Church, on which occasion Dr. Moberly wrote thus to Dr. Buckland :-

' On taking leave of your son Frank from Winchester, I am most anxious to express to you my high sense of his great good conduct and attention while he has been under my care. He has been unfailingly steady and careful in everything which he has had to do, and carries away the character of a most amiable and right-minded fellow.'

'I always,' Bishop Moberly writes again, in 1882, ' had the utmost satisfaction in him as a school-boy; and I look back with very great regard to his simple earnest character, and his devotion to the studies which have made him so well known. To me he was just what I always found him, full of curious information, excellently kind-tempered and affectionate. It is a long time since I saw him, but I always thought of him with great regard and affection.' 


\section{CHAPTER III. \\ CHRIST CHURCH, 1844-1848.}

IN October 1844, Frank Buckland entered Christ Church, Oxford, as a commoner, Dr. Gaisford being then Dean. He was admitted student in December, and remained at Oxford until Easter term 1848, when he took his B.A. degree.

Where the Meadow Buildings of Christ Church now stand, then stood the old 'Fell's Buildings,' already much dilapidated, and which were pulled down in 1858. There was a small court between them and the Canons' gardens.

In Fell's Buildings Frank had his rooms on the ground floor during his college course, and pursued his zoological and surgical studies with equal energy and originality : he made use of the court as a menagerie; continually adding to his collection specimens zoological and anatomical, living and dead. Amongst the former were a young bear named Tiglath Pileser, Jacko the monkey, an eagle, a jackal, besides marmots, guinea-pigs, squirrels and dormice, an adder and many harmless snakes and slow-worms, tortoises, green frogs, and a chameleon. Skeletons and stuffed specimens were numerous, and often anatomical preparations were in progress in the court. The live pets had a tendency to stray. One morning Frank was called in 
haste to remove the marmot from the Chapter-house, as the Chapter was about to meet. Another morning the eagle stationed kimself in the Chapel doorway and attacked those who wished to enter, till he was rolled up in one of the students' gowns and carried off ignominiously.

The long vacations of 1845 and 1846 were passed at (riessen with Baron Liebig, in accordance with the advice of Dean Conybeare of Llandaff, his father's friend and companion in geological research, thus expressed :-

'My young friend Frank, with his talents and your reputation, is quite sure of running a very brilliant career in the profession he has chosen with all the ardent interest that marks genius. Do send him to Liebig in the long vacation; that $I$ am sure will be every way most useful to his career; he is a great friend of mine, and I like him as much for his modesty and civil attention to his seniors as I respect him for his talents and keen powers of observation, which he has inherited and learnt from you.'

Many characteristic reminiscences of Frank's Oxford life are preserved by his fellow-students.

'I remember well,' one writes, '. 'the first time I saw him on my journey to Oxford to matriculate. I was travelling from Salisbury, he from Winchester. At that time the whole journey could not be accomplished by railroad, and I struck the coach at some point. On the box was lirunk, and a very strange-looking little fellow I thought him, but saw at once that he was unlike anyone else. Of course we very soon began to talk, and Frank afforded us plenty of amusement with his conversation. I can see him now, and remember the eager way in which he observed - Mr. Herbert Fisher. 
everything. Once when we stopped to change horses, a lame one was brought out. Frank immediately leapt from the box and proceeded to investigate the cause of the lameness, taking up the horse's foreleg and examining the foct. I believe that he thought he had discovered what was the matter; at all events, he held forth on the subject, much to our amusement and that of the coachman and ostlers. We proceeded on our way, and after a short time Frank took off his hat and pioduced a large moth which he had found that morning in Winchester Chapel, and which he began to examine carefully, calling our attention to its characteristics.

'Recalling that journey, I cannot help remarking that Frank was exactly then what he always continued to be. For of all men whom I have known, I should think that he must have changed the least with advancing years.

'At Christ Church Frank was a member of a small debating society started by Lord Dufferin, to which I also belonged. Besides debates, each member had in turn to contribute an essay. Of course, after the manner of young men, we wrote and debated upon subjects far removed from common life. Imagine, therefore, our amusement when Frank announced as the subject of his first essay, "Whether" Rooks are Beneficial to the Farmer or not." He read his composition with the greatest seriousness. We who were accustomed to discuss the character of Cromwell, Charles I., and so on, were of course almost dying with suppressed laughter at this delicious innovation. I quite forget how Frank settled the matter, or what happened afterwards, when, according to the usual practice, we ought to hare discussed the subject of the essay; but I think he must 
have had it all his own way. I don't think that even Lord Dufferin, with all his versatile genius, made much of the rooks.

' On another occasion I remember his coming armed with a translation of Herodotus, frankly confessing that he rather preferred the English version to the Greek, to discuss some points of Egyptian Natural History. The crocodile and the trochilus came in, I think, for a fair share of attention.'

Another paper read before this society was an elaborate history of the Dodo, collecting all the fragmentary knowledge which exists of this extinct bird.

'Unhappily, of late we scarcely ever met, though at Christ Church I saw him constantly, and he was always just the same; and so $I$ am sure he must have remained to the last, a genuine child of nature, with a mind full of child-like mirth and gaiety, yet rendered serious by the eagerness with which he scanned all natural objects, so intense that no room was left for the slightest thought of self. He seemed to assume that everyone must take as much interest in these things as himself, and this imparted that freshness and sincerity to his conversation which made him so attractive a companion to people of every kind; for he knew no distinction of persons. As I write at this moment, I remember the last time I saw him. It was at the South Kensington Museum. He was explaining his salmon-breeding apparatus to the Duke of Richmond, and looked and talked just as he had done on the Oxford coach.'

'He was the first man,' Dr. Liddon writes, ' who called on me when I came up to Christ Church. I was in 
"garrets" in Peckwater, and had amived the previous night, and, as I knew only a few people, was feeling very lonely and strange. He came into my room after breakfast, and said some cheery words, and told me, I remember, that it was a "good thing to try to liave plenty to say to men." I have always lemembered this visit with gratitude, and this piece of advice; this was in October 1846. He often asked me to breakfast with him in his rooms in "Fell's Buildings." One of these breakfasts was in the spring, and it coincided with a great event; the marmots, which had hybernated in the cellar below, had just, as he expressed it, " thawed." There was great excitement; the creatures ran about the table, as entitled to the honours of the day; though there were other beasts and reptiles in the room too, which in later life would have made breakfasting difficult. Speaking of reptiles, one very early incident in my Oxford life was joining in a hunt of Frank's adder. It had escaped into Mr. Benson's rooms, and was pursued into the bedroom by a group of undergraduates, who had however different objects in view. Frank certainly had the well-being of the adder chiefly at heart; the rest of us, I fear, were governed by the lower motive of escaping being bitten anyhow-if, consistently with the adder's safety, well-if not, still of escaping. Eventually the adder was caught, I believe, without great damage. This must have been in 184.7.

'One day I met Frank just outside Tom Gate. His trowsers' pockets were swollen out to an enormous size; they were full of slow-worms in damp moss. Frank explained to me, that this combination of warmth and moisture was good for the slow-worms, and that they 
enjoyed it. 'They certainly were very lively, poking their' heads out incessantly, while he repressed them with the palms of his liands.

' I was in chapel on that Sunday morning when the eagle came in at the eight o'clock service. The cloister door had been left open, and the bird found its way into the church, while the Te Deum was being sung, and advanced with its wings nearly spread out. Two or three men left their places to deal with it; Dean Gaisford looked unspeakable things.

' Of the bear I have a much less distinct recollection; but the jackal was, I might almost say, a personal friend. He was fastened up in the court outside Fell's Buildings; and I recollect how, under some odd and painful irritation, he used to go round and round, eating off his tail. Frank expressed great sympathy with him, modified by strong curiosity - he wondered how far Jacky would eat up into his back!

'He was certainly one of the most popular men in Christ Church: when he was in the schools, to be examined viva voce, almost the whole undergraduate world of Christ Church was there; I can even now recollect his being put on in a chorus of Sophocles.

'He always struck me, in respect of the most serions matters, as combining strength and simplicity very remarkably; it was impossible to talk to him, and not to be sure that God, life, death and judgment were to him solid and constantly present realities.'

'It is not quite satisfactory,' writes another fellowstudent, ' 'to look back from the present, when the natural 1 Rev. St. John Tyrwhitt. 
sciences are fully and effectually taught in Oxford, and when earnest study in any of them is sure to meet encouragement and ample reward, to a time when an energetic student of physics and born field-naturalist was considered simply off his head for caring about nature.

'A great work has been done for Oxford physical studies, but still more striking and immediate results would certainly have followed, had Frank found proper instruction in physiology here in his youth, and taken his place as one of its teachers in manhood. Both he and Oxford have done pretty well, but Oxford lost much in not keeping him.

' The present Meadow Gate of Christ Church, Oxford, occupies nearly the same ground as that old postern, at the end of that old cloister passage, which elderly Oxford rowing men so well remember as a short way down to the boats.

'The new buildings were yet unthought of, and the space they now occupy was filled, somewhat insecurely and inconveniently, by the chaplain's quadrangle on one side of the passage, and the single garden staircase on the other. The quiet parts of a college are like the quiet streets of London, subject to occasional and powerful disturbances of adjacent echoes by their inhabitants; and at that time, from morn to dewy eve, various sounds intermittingly broke the spell of academic silence in the building abutting on Christ Church Meadow.

'A post-horn or cornet would break forth into irregular practice; a supposed fox would be halloed away from an imaginary cover in the broad-walk; a bear would utter his voice, or it might be a monkey; or one or both animals might obtain temporary freedom and wander about college, 
causing effervescence; in short, tranquillity was far from slumbrous in the more retired parts of "the house;" nor was it at once restored by the appearance of a very broadbacked young man of personal strength and activity greatly exceeding his moderate height, having a shockchestnut-coloured head, a blue pea-jacket, a red German student's cap with a gold tassel, with a presumably harmless snake hanging out of his trowsers' pocket, and bearing a scalpel and a trumpet, or perhaps a long Swiss wooden cow-horn, and coming out from the ground-floor rooms on the right on the garden staircase.

'There hung an odour of physical science about the rooms, which increased as you got nearer. If you passed through the outer room into the study, you found the occupant surrounded by friends and playmates irrational or luman, and deep in scientific investigation after his own fashion; which, be it observed, was as industrious as it was irregular. As the son of a canon and well known to everybody, he was better understood than most persons, and noises never got him into trouble: but I think that the rest of us, who only thought of Greek and Latin reading, if we read at all, never quite understood the reality or the value of the work Frank was engaged in, or that he was in fact educating himself much better than most of us were doing.'

Dr. Merriman, his præfect at Winchester, renewed his friendship with him at Oxford. 'Frank often came to visit me in my ground-floor rooms at New College; I had a nice little piece of garden, wherein I kept a dog and a liedgehog, in both of which Frank took a lively interest.

' Well do I remember his coming in one day, beaming 
with delight, and saying, "Oh! Merriman, I have brought you something you will like; " and then, thrusting his hands into his breast-pocket, he pulled forth and placed on my table a snake.

'I remember also on one occasion going down to Christ Church to see him. As I opened his door he exclaimed, " Oh! Merriman, stop a minute-my adder is out!" I need hardly say I penetrated no farther until I saw him stoop down, catch the thing by the tail-its fangs had not been drawn-and swing it into a drawer, which was immediately shut. Just after this his father came in. It was soon after he was made Dean of Westminster. He had come down to lecture, and, opening the little black bag which he had in his hand, he produced a tortoise for Frank. I have often wondered whether it was the one which has now become famous all the world over as being decreed to be an " insect" in the judgment of the railway officers.

'He came down to me one day for the purpose of telling me what he had for dinner the day before-namels, panther chops! He was a great friend of the curator of the then existing Surrey Zoological Gardens. From him Frank heard one day that the panther was dead. "I wrote up at once," he said, "to tell him to send me down some chops. It had, however, been buried a couple of days, but I got them to dig it up and send me some. It was not very good.",

'One evening,' writes another college friend,' ' when I was devoting an hour to coaching him up for his little go, I took care to tuck up my legs, in Turkish fashion, on the sofa for fear of a casual bite from the jackal which was 
wandering about the room. After a time I heard the animal munching up something under the sofa, and was relieved that he should have found something to occupy him. When our work was finished, I told Buckland that the jackal had found something to eat under the sofa. "My poor guinea-pigs!" he exclaimed; and, sure enough, four or five of them had fallen victims.'

Tiglath Pileser, the bear, was about six months old when he entered Christ Church, where he lived in a corner of a court beside Fell's Buildings. He was provided with cap and gown, and in this costume was taken to wine parties, or went boating with his master, to the wonderment of the children in Christ Church Meadow, who would follow them down the walk leading to the boats, regardless of expostulations and threats, until sometimes the bear was turned loose and shambled after them, whereupon they fled.

Tig, as he was familiarly called, took part in the proceedings of the British Association at Oxford in 1847, attending in cap and gown the garden party at the Botanic Gardens, and receiving a visit from Lord Houghton, then Mr. Monckton Milnes, who attempted to mesmerise him in his corner. This made the bear furious, but he gradually yielded to the influence, and at last fell senseless on the ground.

Of this meeting Sir Charles Lyell wrote: ' In the evening we had an immense party at the Botanic Gardens. Young Buckland had a young bear dressed up as a student of Christ Church, witll cap and gown, whom he formally introduced to me and successively to the Prince Canino (Charles Buonaparte), Milne Edwards, member of the 
French Institute, and Sir T. Acland. The bear sucked all our hands and was very caressing. Amid our shouts of laughter in the garden by moonlight, it was diverting to see two or three of the dons, who were very shy, not knowing how far their dignity was compromised.'

Tig at last fell under the censure of the Dean of Christ Church. 'Mr. Buckland,' the Dean is reported to have said, 'I hear you keep a bear in college; well, either you or your bear must go.'

So Tig was sent to Islip, a living held by Dean Buckland, seven miles from Oxford, and lived there for some months with the eagle and Jacko, who had also been rusticated. Tig sometimes rode out on horseback with his master, at other times he took walking exercise, following any who would allow him to suck their fingers. This unsubstantial solace was so much to his taste that it was needful to provide a lump of sugar to induce him to let go.

From Islip, Tig once visited Canon and Mrs. Rawlinson at the neighbouring village of Merton, and was first put in the stable; but the horses became so excited that he was removed to an outhouse. Soon after a maid, running across the fields breathless and capless, called Mrs. Rawlinson back from her walk, crying out that the bear had got loose ; they were all afraid to catch him; he was in the kitchen, and the leg of mutton roasting for luncheon would be eaten up. Returning instantly, there appeared a doubt whether the bear was in the kitchen or the scullery; the cook had shut herself up in one, and the bear in the other. Both were, however, soon released, and the bear again consigned to his outhouse. He soon escaped again, and walked up into the nursery, where the first-born baby was 
sleeping. Father and mother ran upstairs and met Tig walking out of the room, learing the child quietly sleeping.

After this Tig was sent back to his master. Led by a chain, he trotted quietly along until in one of the fields a flock of sheep came in view. This temptation he could not withstand, he was off in an instant after them. The poor old shepherd, his dog and the sheep, all fled, with the bear after them, enjoying the fun. At last Tig was caught by his conductor, who picked him up and carried him the rest of the way to Islip.

At Islip, news came one day that the bear had broken his chain and was in the grocer's shop, devouring the sugar and sweetstuff, and terrifying the shop-woman out of her wits. She had retired to the back parlour, leaving him in possession of the shop, and had sent a messenger out at the back door for relief. After this the bear dereloped such a prochivity for the sweetstuff shop, to the damage of the woman's nerves and his master's pocket, that in November 1847 he was sent to the Zoological Gardens, where he died some time after in an effort to cut his teeth.

The exploits of the eagle and of Jacko are recorded in the second volume of 'Curiosities of Natural History.'

The snakes had the advantage of frequent change of scene, as they visited all the rooms on the staircase and were indulged with excursions in their proprietor's pockets, sometimes as far as London, where in Oxford Street one day Frank produced a very fine one, exhibiting him at full length to the astonishment of passengers.

The chameleon used to stand upon an inverted wineglass with his tail round the stem and assimilate flies. 
This le did with a concentrated gravity and entire want of speculation in his opaque and protruding eyes, which convulsed wine parties, especially when he concluded his performance by tumbling head-foremost into the preserved ginger.

One of the Christ Church tutors was wont to say, in a halfserious way, that he had once seen the devil. It was in this way : on returning to his College rooms one evening in the twilight, and proceeding to hang up his cap and gown, he had the sensation of not being alone in the room, of a shadow now here, now there, as he turned, but no sound. He waited-yes, there must be some one or something in the room. He called his scout to help him search; when on the top of his window, clinging to the curtain in the dark, they saw the outline of Jacko, looking very uncanny indeed : a chase began, which ended by Jacko popping out of the window into Dr. Pusey's fig-tree, and thus making off through the gardens.

In June 1845 Frank Buckland left Oxford for Giessen, and remained there three months, studying chemistry with Professor Liebig.

The daily routine of Giessen life seems to have been :-

'Breakfast when anyone chooses, as they do not meet at that meal. Dinner at 12.30 or 1 o'clock. Tea about 5 ; supper about 8 . The students generally work all the morning and a good part of the afternoon, and in the evening go out for a walk to some neighbouring place, where they drink beer and eat thick milk. I went last night with some students and had some of this milk, which is milk from the cow put into jars, and let stand for two days, when it becomes quite thick: it is then poured out into a 
soup basin and eaten with sugar and spice; I think it is very good.'

Sir Benjamin Brodie's son, afterwards Professor of Chemistry at Oxford, was at that time also working in the laboratory at Giessen.

The first few weeks were chiefly devoted to acquiring a sufficient knowledge of German to enable him to profit by the professar's lectures.

From Giessen he wrote home in June 1845:-

'In the tower' of the church is a house where a man lives whose duty it is to walk round a parapet all night to watch for fires; he blows his horn frequently to show he is there, and he has the bells at his command to give alarm if necessary.'

'At the top of a chimney at the police station is a stork's nest, and there are three or four young storks who live up there, and look down on the people with the greatest confidence: they are almost held sacred. The old storks are continually seen flying about for food. They don't mind the smoke, and the sparrows have built their nests among the twigs of that of the storks, which when seen from the neighbouring Botanical Gardens looks like a round faggot. All the countrymen here (Bauers) are dressed in blue smock frocks, and some of the old fellows wear a kind of three-cornered hat and knee-breeches, shoes with buckles, and black stockings. The women are all dressed "Buy-ahroom" fashion, and wear tremendous bustles and short petticoats. They gather the hair from all sides of the head into one plait, which, if they are going to carry axything, they twist in a circle for a cushion, at other times they keep it in a kind of little box tied with strings; many of these 
people have in addition high-heeled shoes, all broad round faces. There are not many horses here, but the better sort of peasants drive oxen in their carts, the others corvs, which are more plentiful. These all draw by a rope fastened to their horns, and certainly do not look comfortable; the cows are shod. I went out one day shooting in a forest; we only killed two young rooks. I heard two golden orioles singing, but could not get near them; I saw two or three ravens and a kite, jays, and magpies, and a roe. In the ponds about here are a great many frogs nearly green, but as large as the common English one. I have not been able to find any little green ones yet; they are not very common, I believe. These big green ones make a great noise at night, and all round Giessen you hear them although some way off: they live in the water, not on the trees. They have a pouch by which they make this noise, which is quite peculiar. I think the stork helps to thin them considerably. I have told a little strawberry boy to catch me as many as he can, and also snakes; I hope to import some frogs and red slugs into England. A man shot a polecat in the forest, and he has given me the body, which is now in the forest in a large ants' nest.'

In a subsequent letter he writes:-

'Somebody has taken away my polecat from the ants' nest, where I put him in the forest. The storks are quite well, and they are beginning to learn to fly, by jumping up into the air and opening their wings. There is a tame stork kept in the stable of an inn in the country, which I went to see; an old woman drives him out in the fields to feed, and home in the evening; he stalks along in a very dignitied manner.' 
The description of a Giessen dinner is as follows:-

'Soup made with pearl-barley or macaroni, followed by boiled beef (Ochsenfleisch) carved German fashion, i.e. the joint held down to the plate with a fork, and hunches, two or three inches thick, cut off, with perfect indifference to fat or lean, eaten with oily salad and vegetables smashed up together-these latter very good.'

- July 17.

'There was a large cattle market here the other day: an immense quantity of cows (all sold in pairs), some very bad horses, and some bulls. The fair consisted of three rows of stalls : in one were whips, \&c., in another nothing but caps, and in another cloth, \&c., and riband. Many of the people had come from a great distance. It was rather a ridiculous sight to see one old man with knee-breeches, shoes with buckles, and a cocked hat, driving a lot of pigs. I saw several of these fellows, in the middle of the day, lying fast asleep with their pigs, by the side of the road. The pigs have long noses, long legs, and a long mane of bristles all down their backs. They are kept famously in order by a dog, who pulls them by the ear if they do wrong. I saw a dog bring one out from under a cart, and through a lot of people, to the others, by the ear; lie let him go directly he had come to his brothers. There were tivo rows of about thirty country women, who had each her basket with some coarse stuff, like sheets, which I suppose they had made themselves: they sat there with their linen nearly all day, but did not seem to sell much. When the Bauers go home from work, they always sing; last night I heord them in the forest in all directions, singing as they 
returned from the market. It seemed to he a kind of chant to keep time with their steps.

'The anatomist, who lives above me in my lodging, has got a dog, with a silver tube in his stomach, which is stopped up with a cork; the object is to get gastric juice fresh for the lecture; the dog seems very well but rather unhappy.'

'July 29.

'An accident occurred about a week ago at the farm which Liebig is building about two miles from Giessen. Two men were digging a well through a hill of sandthey had got down fifty-two feet, when all of a sudden down came the sand upon them. One of them saw it coming, and by dint of immense exertion scrambled up as it fell, and just got his head into the air; the other poor fellow was buried. They were discovered in an hour, and an alarm was given; this was at 8 o'cluck. At 10 o'clock I heard that the manganese mines had fallen in and that fifty men were killed. I rushed off as hard as I could go ; but they told me there that it was at Liebig's Hill that the accident had taken place; so I rushed back and got up to Liebig's Hill about 1.30. There I found a number of miners with a windlass and buckets, working away as fast as possible (they had been working since 9 that morning). Just as I came they found the poor man's head, but he was quite dead. I then saw them bring him up in a basket from the bottom; they put him on the grass and tried to revive him, but of course could not, as he had been under the sand from 8 till 2. I got close to lyim, to see how they treated him. He was carried off to 
the cemetery, and rings put on his fingers in such a manner that the least mevement would ring a bell. On the Wednesday following he was buried, and I heard all the miners were to attend. I went at 9 o'clock to the cemetery. It was quite dark. The miners formed a long procession and marched through the town; many had torches, but those who had not, had their mining lamps; a band of music preceded them, and altogether it was a very curious sight. They marched slowly to the grave, where a ring was formed by the miners, and the clergyman of the Protestant church advanced and gave is kind of sermon for a quarter of an hour; the crackling of the torches and the man's voice were all that could be heard. They then went home in procession without music. Liebig was very much affected by the accident: he paid the expenses of the funeral, and sent his son George to attend it.'

'August 3.

'I understand much more than I did at first, and generally manage to get two or three facts out of the lectures, though of course these intricate combinations, explained in a language which I must construe in my mind before I can understand, are rather difficult.

'When a young man begins here, he generally goes through the course of analysing a set of one hundred bottles, which takes him sometimes a year. These bottles are various compounds, which he must find out-viz. in the first ten he has only to find one metal, \&c. ; in the second, two metals or substances, \&c. ; till at last the highest bottles contain six or seven substances, all of which he must find out. Liebig thought I bad better not begin 
these, as I had to learn German, and to stay only a short time here. However, I think I know more chemistry than when I came. About 3 o'clock Liebig comes into the laboratory, and he seems to be able to tell everybody, whatever they may be doing, what to expect, and how to proceed.

'I have bought some of the frogs that make such a noise all about the ponds at Giessen. They are half green, their legs being brown as the English frogs; I inflated one and squeezed the air towards his mouth, and out of the sides of his jaws sprang two bladders. I suppose these are used to make the curious loud noise for which they are remarkable.

'There was a student's funeral last Friday by torchlight; there were nearly three hundred torches.

'The students' full dress seems to be, leather breeches and high boots, a velvet jacket and a sword. Some of them are very fine fellows. I have bought a book of their songs. When they leturned from the funeral, they made a honfire with their torches, and sang a Latin song, "Gaudeamus igitur juvenes dum sumus," to a very peculiar tune. They also sang a farewell over their conrade's grave, and a sermon was preached by the professor of theology, who is quite a young man.

'Returning from the University of Giessen in October 184.5, I brought with me,' he wrote, ' 'about a dozen green tree-frogs, which I had caught in the woods near the town. 'The Germans call them Laub-Frosch or leaf-frog; they are most difficult things to find, on account of their colour so much resembling the leaves on which they live. I have

1 Curiosities of Natural History, first series, p. 15. 
frequently heard one singing in a small bush, and, though I have searched carefully, have not been able to find him; the only way is to remain quite quiet till he again begins his song. After much ambush work, at length I collected a dozen frogs and put them in a bottle. I started at night on my homerward journey by the diligence, and I put the bottle containing the frogs into the pocket inside the diligence. My fellow-passengers were sleepy cld smokedried Germans. Very little conversation took place, and, after the first mile, every one settled himself to sleep, and soon all were snoring. I suddenly awoke with a start, and found all the sleepers had been roused at the same moment. On their sleepy faces were depicted fear and anger. What had woke us all up so suddenly? The morning was just breaking, and my frog's, though in the dark pocket of the coach, had found it out, and, with one accord, all twelve of them had begun their morning song. As if at a given signal, they one and all of them began to croak as hard as ever they could. The noise their united concert made, seemed, in the closed compartment of the coach, quite deafening: well might the Germans look angry; they wanted to throw the frogs, bottle and all, out of the window, but I gave the bottle a good shaking, and made the frogs keep quiet. The Germans all went to sleep again, but I was obliged to remain awake to shake the frogs when they began to croak. It was lucky that 1 did so, for they tried to begin their concert again two or three times. These frogs came safely to Oxford, and, the day after their arrival, a stupid housemaid took off the top of the bottle to see what was inside; one of the frogs croaked at that instant, and so frightened her that she 
dared not put the cover on again. They all got loose in the garden, where I believe the ducks ate them, for I never heard or saw them again.'

On November 12, 1845, Frank Buckland's father was made Dean of Westminster, and was installed on December 12. In January 1846 Dr. Buckland removed from Christ Church to the Deanery, Westminster, at the same time taking the living of Islip, Oxon, which was then held with the Deanery, and became their country home.

On returning to Giessen in July 1846, Frank writes :-

' July 19.

' I find Giessen just as I left it. The family seemed all glad to see me, and nothing could be kinder than the professor in erery respect. He has arranged everything for me very comfortably. He said it would be better to have some regular lessons in chemistry, so that now I go every morning to his assistant for an hour. I will put down what my occupation here now is : $7.30-8.30$, chemistry ; 9-10, German with Dr. Adrian ; 10-11, laboratory ; 11-1, Liebig's lecture; 1-2.30, dinner. After dinner I occupy myself with chemistry in the laboratory, or German, as the case may be, till about 6 or 7 . If ever there was a place to work in, it is Giessen. The people never think of leaving off work till 6 or 7 ; whereas in Oxford the books are shut at the latest at 2 o'clock.

'Liebig invited me to go with him last Friday to the Braunstein (black oxide of manganese) mines, about three miles from Giessen. The master of the place met us and took us over the mine. The metal is very plentiful ; it is in a bed dipping from east to west, as can be seen by the 
depth of the different shafts. In one place they have made a deep square hole, on one side of which one can see a beautiful section. The brantistein lies in wavy lines, and above are clays of many beautiful colours, generally red with white streaks interposed. Altogether, it presents the most curious appearance. All these works belong to a lawyer, who found a bit of the stone and took it to Liebig, who advised him to buy the land, which he did, and hàs now made his fortune. It is sent in barrels down the Rhine and then by ship to Glasgow and London, to be used in bleaching linen. Professor Liebig has given me a beantiful specimen of this manganese covered with black crystals.

'I went on Saturday to the Säffenburgh Woods with a party. I slipped away to look at the duelling-place of the students. It is a little flat piece in the middle of the wood, and commands a view of all the approaches to it, so that the fighters cannot be surprised.

'Last Wednesday the town was honoured by a visit from the son of the Duke of Hesse Darmstadt. This made a great bustle in the town; all the professors went down to receive him, and in the evening the tradesmen got up a Fackelzier or torch-light procession, which had a very good effect. The Glee Club played under his windows, and while this was going on I went upon the top of the tower (where the people look out for fires), and got a capital view of the whole thing without being pushed about by the crowd, or having my clothes covered with the droppings of the torches. While up here, the old man who keeps watch all night told me that he had just before been very much alarmed by the whole tower shaking from side to 
sicle, so much that he thought it would fall, and some water in a bucket was thrown out on the flool. Well, I thought some part of the bulding had probably given way; but on going down, I found everyone with the word eartliquake on the tip of their tongues. It seems probable that the whole of the lower part of Giessen, in which the church stands, was shaken considerably, but that the upper part was not at all affected. The keeper of the forest, about three miles off, tells me he observed the rooks flying about much frightened, and that the people in the neighbouring villages ran out of their rickety mud and wood houses, which shook so as to appear about to fall every moment.

"I cannot bear the thought of the loss of "Freiheit" at Oxford, after that enjoyed by the students and myself with them here at Giessen; besides I find the studies so much more agreeable here than there; but I hope if I lire to make my exam. before next long vacation.'

In September 1846, after a short tour in Switzerland, Frank Buckland returned to Oxford. He brought with him this time a jar full of the red slugs he wished to introduce into England; they at least were noiseless and would not croak like frogs. In the opposite corner of the diligence placidly slumbered a traveller with ample bald head; Frank also slept, but, waking at midnight, he saw with horror that two of his red slugs had escaped and were crawling over the traveller's bald pate. What was to be done?" To remove them might waken the sleeper. Frank sat as it were on tenterhooks until the diligence stopped at the next stage, when firmly covering up the jar and what remained of the slugs, he slipped quietly out of the diligence, 
resolved to proceed on his journey by another conveyance next morning, rather than face that man's awakening.

During his university course Frank constantly attended the lectures of his father, Dr. Buckland, to whose training he through life acknowledged himself indebted, and whose vivid and witty power of expression and illustration he seemed to inherit.

In May 1848, he took his B.A. degree, and immediately afterwards entered St. George's Hospital.

Two extracts from his 'Private Journal' for 1846-7 show that beneath the surface of character which bubbled over with fun, there flowed a deep stream of earnest purpose.

' July 26, 1846.-My object in studying medicine (and may God prosper it !) is not to gain a name, money, and high practice, but to do good to my fellow-creatures and assist them in the hour of need.'

'August 9.-My object in life, to be a great high priest of nature, and a great benefactor of mankind.' 


\section{CHAPTER IV.}

ST. GEORGE'S, $1848-1853$.

IN May 1848 Frank Buckland left Oxford and commenced studying surgery at St. George's Hospital, acting first as dresser to Mr. Tatum and Mr. Cutler, then surgeons to the hospital. In May 1851 he passed the College of Surgeons. In May 1852 he became house surgeon at St. George's, which appointment he held until June 1853.

His unfailing kindliness and love of fun soon made him a favourite both with the hospital staff and with the patients. One poor woman greatly troubled at her boy's thumb being amputated, he soothed, it is said, by persuading her that Tommy's thumb might grow again; and when she called to tell him reproachfully that Tommy's thumb had not yet grown, he could only exhort her to further patience.

He used to say ${ }^{1}$ that the cases which were brought into the accident ward grouped themselves into classes according to the hours of the day. The suicides came at an early hour of the morning; the scaffold accidents next, since a scaffold, if it gave way at all, gave way early in the day; the street accidents afterwards, and so on.

One of his patients, he used to tell, an old woman, came to the hospital with a cough, which she declared

' Macmillan's Magazine, 1881, p. 304. 
nothing would alleviate except some sweet luscious mixtuve which another out-patient, a friend of hers, had received. The old woman was given a bottleful of the mixture, and returned again and again for more, though her cough got little better. At last his suspicions were aroused, and he desired that his patient should be watched. She was watched, and was found outside Chelsea Hospital selling the mixture in halfpenny tarts.

Another reminiscence of St. George's was connected with the practice of tattooing, which, as he used to tell, ' is sometimes adopted by the fair sex of the present day. Ladies who are about to have the initials of their sweethearts permanently engraved on their arms should be careful to make up their minds not to change their sweethearts unless the same initials will suit. When house surgeon at St. George's, a charming creature came to me in great distress. She said there was nothing the matter with her, but she was in great trouble because her young man had been faithless. He had persuaded her to allow his initials, with a true lovers' knot, to be tattooed on her arm. She had quarrelled with him, and was now anxious to erase all traces of their attachment. The design on the arm was too big for any operation, and the girl, for aught I know, still continues to carry about a fine specimen of the art of tattooing.'

While at St. George's he 'saw much society at the Deanery,' which, under the genial hospitality of the Dean and Mrs. Buckland, had become a centre of scientific and intellectual society in London.

The following extracts from the Journal for 1849 , which also contains a full detail of his hospital work, 
show both the society he enjoyed, and also how his lore for natural history maintained its hold upon him :-

'New Year's Day.-I will see whether I can be wiser and better at the end of the year.

'January 3.-Lectures began again at St. George's, with Pitman and Tatum. Hewett began the muscles, Pollock assisting him.

'January 4.-Got the office of assisting Pollock in dissecting.

'January 12,-Gave Jacko chloroform: very successful.

' January 13.-Large microscope party: Dr. Carpenter, Mr. Bowerbank, Sir B. Brodie, Messrs. Spence, Pollock, Ogle, the Fittons, Hawes, Forbes, Lady Shelley, Miss Burdett Coutts, Dr. and Mrs. Playfair, and others.

'January 16.-Man sent me a monkey from Zoological Gardens.

'February 19.-Went all over the top of the Abbey with Mr. Scott (Sir Gilbert Scott), the new architect.

'February 26. - Went to a party at Miss Coutts': Duke of Wellington, Wheatstone, Lady Chantrey, Monckton Milnes, and many very great people there.

'March 2.- Saw the man who could sing both treble and bass at the same time: very curious but very sweet.

'March 5.-Went to Dr. Carpenter's party; saw some objects under the microscope, echinus's spines, horse's hoof, eel's scales, \&c. Went with large party-Mr. and Mrs. Gladstone, Lady Waldegrave, and Mr. Harcourt, Mrs. Malcolm, and the Misses Johnson-to see the Nineveh sculptures (at the British Museum); vers beautiful and interesting. 
'March 9.--Party of Huxley, Blagden, Rolfs. Had the lump fish for dinner : very good, something like turtle.

'March 10.-Rather seedy from the lump fish.

'March 17.-Went with the Dean to British Museum to see Nineveh remains. Lord and Lady Russell there: introduced to them. Lord Northampton going round. Sir H. De la Beche also there.'

'March 19.-Dined with Lord Ellesmere at 18 Belgrave Square: beautiful rooms. The Malcolms the only people there. Much talk with Miss Egerton and Lord Ellesmere about zoology. Altogether much pleased. Hope I gave satisfaction. Tried to do so.

'March 23.-Went with the Dean to Mr. Arbuthnot's. Introduced to the Duke of Wellington by him. Talked about chloroform and the Nineveh monuments. Saw the Duke's splendid plate presented by Austria and Belgium. Prince Albert just leaving as we arrived. Went to the new Geological Museum with the Harcourts, Lady Waldegrave, Baroness Rothschild, Lord Norreys, and several others. Saw some Californian gold.

'March 25.-Huxley stayed in the hospital for me, while I dined at Sir John Pakington's. Introduced to Sir Robert Peel, Lord Lincoln, and Lord Aberdeen.

'April 1.-E. Forbes, Manby, and a French engineer came to lunch, also the Whewells, Mr., Mrs., and Miss Jones Loyd, Colquhoun also. Took the party round the Abbey. Got locked in : tolled the bell to get out again.

'April 5.-Eagle broke his leg: set it.

' May 8.-Archbishop of Dublin (Whately) and Professor Owen came to breakfast. Landseer came afterwards to see the monkey and the eagle. 
' May 25.-Large luncheon party. Gave the eagle, the suake, and the fish chloroform: all succeeded.

'May 30.-Bartlett of the Zoological Gardens sent me a kangaroo and a gazelle to prepare and find cause of death.'

Among the frequent guests at the Deanery at this time were Deans Conybeare and Peacock, Sedgwick, De la Beche, Murchison, Lyell, Lord Enniskillen, and Sir Philip Egerton among geologists, who laid the foundation of the study of the history of the globe; Sir Humphry Davy and Faraday, who analysed its composition and explored its subtler forces; Edward Forbes, Owen, Quekett, and Hooker, eminent in different branches of the study of animal and vegetable life; Sir John Herschel, Airy, and Whewell among astronomers and mathematicians; Brunel and Robert Stephenson among engineers; Bunsen, Guizot, Liebig, and Agassiz among foreign savants; Archbishop Whately, Ruskin, Rogers, Nassau Senior, Mrs. Somerville, Lady Shelley, and Mrs. Marcet represented literature; Lord Brougham, Sir Robert Peel, Lord John Russell, Lord Monteagle, Lord Northampton, and others, politics; Lady Franklin came with the Arctic explorers Scoresby, Richardson, and Maclintock, and Inglefield, who took with him a detachment of white rats from the Deanery to the Polar regions. These and many more formed an intellectual and scientific society the brilliance of which few are left to remember.

The menagerie at the Deanery was also extensive. As visitors entered the hall and passed thence to the Abber, the stuffed forms of Billy the hyæna and Tiglath Pileser the bear seemed prowling about the passage. Snakes were 
kept in a glass case or in extemporaneous cages, whence they sometimes strayed, and were met casually on the stairs, to the alarm of those visitors whose department of science did not enable them readily to distinguish between the venomous and harmless species.

The eagle had come to London from Islip, and now lived on a pole in the small garden of the Deanery, whence on the 10th of April, 1848, the day of Chartist riot, he escaped, and soared aloft over the Abbey, as is fully related in 'Curiosities of Natural History.' '

Jacko had also migrated from Islip, and chattered from his pole in the middle of the kitchen, where he rejoiced in plentiful blackbeetles, and occasionally assisted the servants, in their absence, by scouring the candlesticks with black lead, and the kitchen table with cochineal, or, with mistaken zeal, filling the inside of the shoes with blacking. ${ }^{2}$

Another large ape, Jenny, caught when quite young on the rock of Gibraltar, joined the party in 1849, and used to lift up her hideous face and kiss her master with great profession of affection. Medicine Jenny would only take if stolen. Her master poured it out as if for himself, and pretended to sleep, when the monkey would stealthily approach and sip up what she imagined to be her master's wine.

Hedgehogs, tortoises, dogs, cats-especially a tailless Manx cat, with one blue and one green eye-rats, bats, hawks, owls, and an aviary of various birds, chameleons and other lizards, bowls of gold fish, and water newts, completed the collection.

1 Second series, p. 102.

${ }^{2}$ First series, p. 291. 
The rats, often fifty or sixty in number, black, brown, white, and piebald, were usually kept in the cellar. Selected white rats were brought up at evening parties for the amusement or torment of the visitors. Snakes were often brought out on these occasions. Frank would produce them from his pocket, or gliding out of his sleeve. 'Don't be afraid,' said he one evening to a young lady who sat down to play quadrilles; 'they won't hurt you: I've taken out their fangs. Now do be a good girl, and don't make a fuss ;' and, after a little more persuasion, proceeded to wreathe one snake round her neck, and one round each arm, with which unwonted ornaments she continued to play the dances. His sisters were so often bedecked with similar reptilian necklaces and armlets, that they became used to the somewhat clammy, crawling sensation, which is a drawback to such ornaments.

Chloroform was at this time a recent invention, and the Dean gave several luncheon parties, at which, with Frank's assistance, the effects of the new anæsthetic were tried on various animals.

The eagle was sent to sleep, and could be lifted up by his feet, like a dead bird; or, when half asleep, was walked round the room by two persons, holding him by his wings. One day the eagle was slowly recovering from his stupor, and walking unsteadily upon the floor, when Jacko was brought in to take his turn. He came in with a suspicious and melancholy expression, expecting that something was going to take place; but when he saw the intoxicated condition of his old enemy the eagle, he jumped out of his master's arms with a scream of delight, and seizing the eagle by the tail, paid off old scores by dragging him 
about the room backwards in a most ludicrous and undignified manner; nor was Jacko secured again till he had espied the bowl of gold fish and thrown them all about the room. Jacko chattered pitifully, however, when his turn came, and then he succumbed. The gold fish, when blotting paper soaked in chloroform was suspended over their bowl, turned on their backs, appearing lifeless until revived with fresh water; the snakes also seemed to die, and come again to life.

Frank's training for the acclimatisation of animals for food, to which he aiterwards devoted much energy, began early.

At his father's table at Christ Church the viands were varied. A horse belonging to his brother-in-law having been shot, Dr. Buckland had the tongue pickled and served up at a large luncheon party, and the guests enjoyed it much, until told what they had eaten.

Alligator was a rare delicacy, as told in the first volume of 'Curiosities,' but puppies were occasionally, and mice frequently eaten. So also at the Deanery, hedgehogs, tortoise, potted ostrich, and uccasionally rats, frogs, and snails, were served up for the delectation of favoured guests. 'Party at the Deanery,' one guest notes; 'tripe for dinner ; don't like crocodile for breakfast.'

In the autumn of 184:9 Frank Buckland went for two months to Paris, to study at the hospitals there in time of cholera. On July 31 he 'packed for Paris, put in skeletons to make,' and started the following day, August 1, travelling viâ Winchester, Havre, and Rouen.

From Paris he wrote home on August 6 :-

'At Havre I saw a great crowd in the street; I found 
they were looking at a star; it was twelve o'clock in the day. There the star was plain enough, only it required good eyes to see it.' I acted as lioniser to an Englishman with his two sons. You may judge what a talented man he was from the observation he made to me, that there were a great many gambling houses in Havre; I did not understand, and asked him why. He answered, because he saw written on many houses Chambres à louer. This he considered connected with cards.

' On Friday erening I went by rail to Rouen. I spent four hours in the museums of zoology and antiquities, and was charmed with them, and have learnt much from the old curator. In the street I saw an old woman selling fruit; in her lap was a parrot, which gave the alarm whenever anyone came to look at the fruit. The woman was asleep under an umbrella tied to the back of her chair. The parrot seemed to know its work, and required to be caressed when the old woman awoke. This would make a good picture. I arrived in Paris late Saturday night. On Sunday evening, at Versailles, I met two St. George's men; they put me in the way of ererything at once, so I have lost no time; I have been this morning round the wards of La Charité, and have begun a course of operations on the dead body, yet I have hardly been here twenty-four hours. Only think, we have a fresh subject every day, and may perform any operation we like.

'Augrust 21.

'My medical studies take up so much of my attention that I have not seen anything except the Louvre and the

1 Venus is often visible to the naked eye in the daytime. 
Exposition ; for you know most things close at four, and I have not finished my operations till 2.30, when I don't feel ready for sight-seeing. The French students are intelligent for the most part, but don't work like Germans.

- September 11.

'I have been into all the curiosity shops here, but as vet have seen nothing good enough to buy for the Hunterian Museum. I have, however, made several notes of little things not known in London. They have a peculiar art of making preparations here to show the arteries and muscles : this I pumped out of the demonstrator at the operating room, and, if $I$ can get a chance, I shall buy a small one for a specimen. The operations are still going on. I have tied all the arteries several times, and performed all the amputations and resections of the bones, the most difficult of all. I feel great confidence now in my hands, a pleasant sensation, such as before I had not experienced. I frequently go round the wards of $\mathrm{La}$ Charité. I have been to Montmartre and found several good crystals there; they do not work the quarries now, but the view from the windmills is magnificent. I have two more weeks to stay here. I intend to take a little holiday and see Grenelle and more museums. I shall try hard to get into the Catacombs, but this is difficult. One day I must go to Alport to" see the hospital for animals, horses, dogs, \&c., and another day to see the horse slaughter-house.

'If I have time I shall go to Fontainebleau; but I take Burchell's arlvice, which he gave me about travelling, i.e. to follow up one subject in sight-seeing. Museums must 
be my line, and if I have time for other things, so much the better, but my own trade first.'

On his return to England his selection of souvenirs of Paris for himself and his friends, as shown by his Journal, is characteristic.

'September 21.-Bought a beautiful skull and some books for J. Ogle; bought a little owl rare in England.

'22.-Bought another owl.'

The following are further extracts from the same Journal :-

'October 8.- Set the owl's leg again.

'October 11.-Went to Terton to see Noel : introduced to his family. Saw Jenny the monkey, which they gave me.

' October 12.-Raining hard; walked about in the park; found a mole in a trap; looked over Mrs. Noel's collection ; some curious things-shells, minerals, mantis, \&c. Took the monkey home; put her in the stable; went to hear Dr. Mantell's lecture on Corals : amusing and instructive.

' October 14.-Monkey got loose; trouble to catch her again.

'October 15.-Put the monkey on her pole; good place for her.

'October 17.- The Prince of Canino, Professor Owen, and Sir C. Trevelyan breakfasted with us. Round the Abbey; very much amused. The Prince very like his uncle, sharp and intelligent. He put new names to my owls.

'October 24.-Pollock came to see Jenny; killed a cat for the engle; Jenny eats grass.

' October 26.-Jenny got loose; great trouble to catch her; she ran all along the roofs of the houses in Dean Street, and at last ran home.' 
$r$ The history of the chase is narrated in 'Curiosities of Natural History.' 1

'November 4.-The owl died. Saw Dr. Mantell's bones of a new large Wealden lizard.

- November 19.-Prince Albert came to the Abbey with Colonel Gordon and Colonel Grey. Saw the Royal Monuments, said they were the worst in the place; I carried the keys, and he talked with me about the German students.

'December 8.--Went with Pollock to the Zoological Gardens: saw the new snake house; saw the boa eat a rabbit; heard the rattlesnake's rattle going, saw some of Cleopatra's asps, and some very young slow-worms. Owen to give a lecture next Tuesday upon the rhinoceros that lias died.

'December 11.-Went to the Zoological to hear Owen's paper on the rhinoceros; talk with Mr. Mitchell about the rhinoceros.

'December 12. - Sent my owl to the Zoological Gardens.

' December 17.-Dined with Lord Chief Baron Pollock and family; very pleasant party. Saw the microscope, and learned about his wells, \&c. He says he is an encyclopædist, and he seems to know everything.

'December 26. - Went to the Museum at Oxford; there a long time; begin to appreciate the collection there.'

In 1850 , a short trip to Guernsey with Professor Huxley, then his fellow-student at St. George's, varied his professional studies.

In 1851, the year of the Great Exhibition, Professor

' First series, p. 311. 
Liebig and many other foreign savants visited the Deanery.

In this year the pendulum experiment, first tried in France in 1845 , to render visible the rotation of the earth, was exhibited at the Polytechnic. Frank, aided by two of Chief Baron Pollock's sons, suspended a weight from the roof of the nave of Westminster Abbey, opposite to the entrance from the Deanery, to show the same experiment, which was an object of much scientific interest. The pendulum appears in the course of the day to traverse the circuit of a dial placed beneath it, the dial in fact rotating with the motion of the earth, the pendulum maintaining one constant direction.

In the same year Frank Buckland made his first attempt at authorship, but an unsuccessful one; the paper was upon the muscles of the arm, and had the approval of Professor Owen. The Diary records successive visits in June, July, and August to different publishers, none of whom would accept the article.

In the following year, 1852, his first article was published, as thus described by his old friend Mr. White Cocper, the Queen's oculist :-

'In the spring of 1852 , when calling at the Deaner's, Frank asked me to go downstairs and see his rats. I am not particularly partial to those animals; but down we went to a sort of cloister, in which probably a dozen rats were encaged: these Frank took out one by one, and described in a most interesting way the habits and peculiarities of each. Presently a large black rat bolted. "Look out! he bites!" said Frank, but the black gentleman was speedily secured by a bag being thrown over him. 
"When I had seen all that was to be seen, I said, "Frank, just you put down on paper all that you have told me about these rats, add what you please, let me have the manuscript, and I will see whether something cannot be made out of it." Frank demurred, saying that he did not think he could write anything worth reading.

'After some encouragement, he promised to comply with my request, and in due time the manuscript arrived; having touched it up a little, I took it to Mr. Richard Bentley, with whom I was well acquainted, and said, "Mr. Bentley, I am going to introduce a new contributor to your Miscellany ; one who will strike out quite an original line." Mr. Bentley was not greatly impressed by what I said, but accepted the MS., which appeared as an article in the Miscellany of the following August; and thus commenced the interesting series, subsequently collected and published as "Curiosities of Natural History."

"Frank often said that the "honorarium" he received from Mr. Bentley for "Rats" was the most delightful surprise he had ever had. The article in "Curiosities" has been considerably expanded beyond its original limits in Bentley.'

The success of the article on Rats led to the publication in the following year of several articles in 'Bentley's Miscellany' and 'Household Words.'

In 1853 he left St. George's Hospital. These events are noticed in his Dial'y of this year, which also contains the first entry of casting, the beginning of that remarkable series of casts which forms the chief part of his museum at South Kensington.

'February 1, 1853.-Article on Cobra in "Bentley." 
'May 21.-Did much of the Monkey paper.

' May 26.-Took my Monkey article to Bentley.

'June 29. - Gave up the house surgeoncy at St. George's.

"July 14.--Wrote article about "Old Bones."

"August 30.-Took my article "Old Bones" to Dickens.

"September 12.-Wrote out article on "Parasites" from 11 to 3.

"October 5.-Wrote out article on "Curiosities at Oxford" for "Household Words."

'October 10. -Made cast of girl's head, and of Ben Jonson's head; also made mould of rat's body.

'October 11.-Up to the Zoological Gardens, and gare the ant-eater some ants, which he would not touch.

'October 12.-Up to the Gardens with six rats; gare them, two to eagle, one to mongoose, two to rattlesnakes, and one to cobra: got poisoned afterwards in skinning the rat.'

The accident with cobra poison, which well-nigh proved fatal to him, he thus described :-1

'I once had painful experience of the awful effects of snake's poison. I have received a dose of the cobra's poison into my system, luckily a minute dose, or I should not have survived it. The accident happened in a very curious way: I was poisoned by the snake, but not bitten by him; I got the,poison second-hand. Anxious to witness the effects of the poison of the cobra upon a rat, I took up a couple in a bag alive to a certain cobra; I took one rat out of the bag and put him into the cage with the snake.

1 Curiosities of Natural History, first series, p. 223. 
The cobra was coiled up among the stones in the centre of the cage, apparently asleep. When he heard the noise of the rat falling into the cage, he just looked up and put out his tongue, hissing at the same time. The rat got into a corner and began washing himself, keeping one eye on the snake, whose appearance he evidently did not half like. Presently the rat ran across the snake's body, and in an instant the latter assumed his fighting attitude. As the rat passed the snake he made a dart, but missing his aim, hit his nose a pretty hard blow against the side of the cage. This accident seemed to anger him, for he spread out his crest, and waved it to and fro in the beautiful manner peculiar to his kind. The rat became alarmed, and ran near him again. Again the cobra made a dart and bit him, but did not, I think, inject any poison into him, the rat being so very active; at least no symptoms of poisoning were shown. The bite nevertheless aroused the ire of the rat, for he gathered himself up for a spring, and, measuring his distance, sprang right on to the neck of the cobra, who was waving about in front of him. This plucky rat, determined to die hard, gave the cobra two or three severe bites in the neck; the snake keeping his body erect all the time, and endeavouring to turn his head round to bite the rat, who was clinging on, like the old man in "Sindbad the Sailor." Soon, however, the cobra changed his tactics. Tired, possibly, with sustaining the weight of the rat, he lowered his head, and the rat finding himself again on terra firma, tried to run away; not so, for the snake, collecting all his force, brought down his erected poison fangs, making his head felt by its weight in giving vigour 
to the blow, right on to the body of the rat. This poor beast now seemed to know that the fight was over, and that he was conquered. He retired to a corner of the cage, and began panting violently, endeavouring at the same time to steady his failing strength with his feet. His eyes were widely dilated, and his mouth open as if gasping for breath. The cobra stood erect over him, hissing and putting out his tongue, as if conscious of victory. In about three minutes the rat fell quietly on his side and expired. The cobra then moved off and took no further notice of his defunct enemy. About ten minutes afterwards the rat was hooked out of the cag'e for me to examine. No external wound could I see anywhere, so I took out my knife and began taking the skin off the rat. I soon discovered two very minute punctures, like small needle holes, in the side of the rat where the fangs of the snake had entered. The parts between the skin and the flesh, and the flesh itself, appeared as though affected with mortification, even though the wound had not been inflicted above a quarter of an hour, if so much.

'Anxious to see if the skin itself was affected, I scraped away the parts on it with my finger-nail. Finding nothing but the punctures, I threw the rat away, and put the knife and skin in my pocket, and started to go away. I had not walked a hundred yards before, all of a sudden, I felt just as if somebody had come behind me and struck me a severe blow on the head and neck, and at the same time I experienced a most acute pain and sense of oppression at the chest, as though a hot iron had been run in and a hundredweight put on the top of it. I knew instantly, from what I had read, that I was poisoned. I 
said as much to my friend, a most intelligent gentleman, who happened to be with me, and told him, if I fell, to give me brandy and eau-de-luce, words which he kept repeating in case he might forget them. At the same time I enjoined him to keep me going, and not on any account to allow me to lie down. I then forgot everything for several minutes, and my friend tells me I rolled about as if very faint and weak. He also informs me that the first thing I did was to fall against him, asking him if I looked seedy. He most wisely answered, "No, you look very well." I don't think he thought so, for his own face was as white as a ghost; I recollect this much. He tells me my face was of a greenish yellow colour. After walking, or rather staggering along, for some minutes, I gradually recovered my senses, and steered for the nearest chemist's shop. Rushing in, I asked for eau-de-luce. Of course he had none, but my eye caught the words "spiritus ammonize," or hartshorn, on a bottle. I reached it down myself, and pouring a large quantity into a tumbler with a little water, both of which articles I found on a soda-water stand in the shop, drank it off, though it burnt my mouth and lips very much. Instantly I felt relief from the pain at the chest and head. The chemist stood aghast, and on my telling him what was the matter, recommended a warm bath. If I had then followed his advice, these words would never have been placed on record. After a second draught at the hartshorn bottle, I proceeded on my way, feeling very stupid and confused.

'On arriving at my friend's residence, close by, he kindly procured me a bottle of brandy, of which I drank four large wine-glasses one after the other, but did not 
feel the least tipsy after the operation. Feeling nearly well, I started on my way home, and then, for the first time, perceived a most acute pain under the nail of the left thumb; this pain also ran up the arm. I set to work to suck the wound, and then found out how the poison had got into the system. About an hour before I examined the dead rat, I had been cleaning the nail with a penknife, and had slightly separated the nail from the skin beneath. Into this little crack the poison had got when I was scraping the rat's skin to examine the wound. How virulent, therefore, must the poison of the cobra be! It already had been circulated in the body of the rat, from which I had imbibed it second-hand.'

'I saw him a day or two after the occurrence,' Mr. White Cooper says; ' he looked ill, and had not recovered from the effects of the cobra poison. There is little doubt that his "pluck," his presence of mind in telling his friend what to do, and the fortunate circumstance of his obtaining ammonia so quickly, saved his life.'

Other articles on the Ant-eater, on Fish, and on Footsteps appeared this year.

In December 1853, Frank Buckland gare his first lecture. Few have excelled him in the power of conveying at once information and amusement. He inherited from his father the faculty of investing a subject, dry in other hands (and how dry lectures often are), with a vivid and picturesque interest, and to this he added a variety of subject and a fund of droll yet apt illustration peculiarly his own. 'I can't get on,' he used to say, 'until I make them laugh; then we are all right.' His drollery was irresist- 
ible, yet was always informing; while his vehement earnestness, and alternation of the serious with the humorous, never failed to arrest attention.

The subject of his first lecture, which was several times repeated, was 'The House we Live in.' It was first delirered at a Working Men's Coffee House and Institute, established by his mother, in Westminster, one of the earliest opened in London. After describing with fertile illustration this excellent house, well fitted up, with no taxes to pay, its pillars and various apartments, the doors and hinges; the front door, the mouth, with the nose as a porter, always on duty except when he has a cold; the windows, the furniture and covering, the pumping apparatus with arteries and veins as pipes; the grand set of sewers; and the telegraph from the mayor and council in the brain; he thus concluded:- 'Many facts which I have mentioned you are doubtless acquainted with; some may be new to you. If, by chance, you have learned anything as regards your own house, I would beg you to ponder over and consider it well. We are all too careless, much too careless, of our bodies. We know not, or, if we do know, we consider not, upon what a slight thread our lives depend. We are all careful of a delicately constructed watch, or other fragile specimen of human handiwork: how careless are we of our own much more delicately constructed bodies; a slight cord snaps, a small artery gives way, our real selves, the immortal part of us, our soul, in an instant quits its mortal tenement, and what remains is but clay. Let this warning remain fixed in our minds, but at the same time let us look upon our 
bodies, each upon his own body, and from his own body to those of inferior animals, as examples of the great Creator's handiwork, that great Creator, so omnipotent, so wise, so benevolent to all here assembled, to all mankind, to all creation.' 


\section{CHAPTER V.}

THE LIFE GUARDS, $1854-1858$.

ON August 14, 1854, Frank Buckland was gazetted assistant surgeon to the Second Life Guards.

In the same month he became a member of the Athenæum Club; his election at the age of twenty-seven showing his popularity, and that his original power was already recognised.

The late Mr. Broderip, a good naturalist, and old friend of Dean Buckland, wrote as follows to Mrs. Buckland, in September 1854 :-

'I thought Frank's admission into the Athenæum of great consequence to him, and exerted myself accordingly, and attended at the ballot, notwithstanding an inflamed eye, and that it would have been better for me to be in bed. Brodie was there doing his duty manfully, like a good man and true as he is.

'Permit me, in reply to your observations, to remind you that, in order to get employment, your son must be known. It is something to have his name, education, and profession suspended for a week in the meeting-room of such a club as the Athenæum, with an overflow of some of the best names in London to answer for him. It is something more to be elected at a season when there has been more black-balling going on than I ever remember; 
nay, on the very night of his election, when one candidate was certainly so excluded, and another, I believe, withdrawn. I hope, and expect, that Frank is made of the stuff that is not fit for ledger work, and I should be very sorry to see him in partnership with anyone. Others as well as myself will be very much out, if he does not eventually occupy a high position in his profession; and it is much better that he should bide his time. I do not object to a surgeoncy in the Guards to begin with.

'Your sincere friend,

'W. F. BRODERIP.'

He retained his commission in the Guards until 1863 , living by turns at the cavalry barracks at Knightsbridge and Albany Street in London, and at Windsor.

Popular alike with officers and men, he was unremittingly kind to the sick, yet strict in enforcing discipline.

His keen perception, which gave him sound diagnosis, and his taste for physiology and surgery, might have led to distinction, had he given himself up to the medical profession; but his passion for natural history absorbed him more and more, and his duties as assistant surgeon in the Life Guards could not fully develope his powers, or satisfy his aspirations; he had not yet found his proper: career, and while he did his work earnestly and well, he was conscious that his natural bent drew him aside from his present calling. ' I think,' he wrote in 18577, 'I am getting too much into the natural history line. 1 must take in the medical papers and write for them also, for I shall get much knowledge from them.' At this date natural history 
seemed to him an amusement, though earnestly studied; it became his life's work.

While in the Guards he continued to write articles for 'Bentley's Miscellany,' 'Household Words,' the 'Leisure Hour,' and other magazines.

Materials of every variety, his mind, singularly alert, was always gathering, and these were stored in numerous note-books.

'Passing thoughts are fleeting; down with them in the note-book ; paper is cheap enough.'

$\mathrm{He}$ also, as his Journal of 1855 records, 'cut out and put together many scraps for my newspaper-book, hoping they will tnin out useful in the article line.'

This habit, persevered in through life, of collecting all kinds of scraps of information, and carefully indexing them, aided by keen powers of observation and a retentive memory, enabled him, both in conversation and writing, to discuss and illustrate almost every subject with a readiness and resource always remarkable.

In 1855 , he was presented to the Queen, at the levee, by Lord Seaton, the colonel of the Second Life Guards.

On June 7 of the same year, he went from Windsor to Oxford, to attend the funeral of Dean Gaisford. His account of it curiously shows how the pursuit of natural history was interwoven with each incident of his life.

'Went to the pond,' his Journal notes, 'and caught some fine lizards for the Zoological Gardens. In the evening went up to Oxford.'

The scene at Oxford he thus described: '-' When in the month of June, 1855, the greatest Greek scholar of

1 Curiosities of Natural IListory, second series, p. 235. 
his day, the Rev. Dr. Gaisford, Dean of Christ Church, was carried to his last resting-place within the walls of the ancient Cathedral over which he had presided so many years, the students of the "house," clad in white surplices, preceded the remains of their venerated Dean, as the procession passed along the east side of the quadrangle from the Deanery to the Cathedral. Great Tom had, by tolling every minute, announced the decease, and now a small hand-bell, carried in front of the procession by the Dean's verger and tolled every half-minute, announced that the last rites were about to take place. I was of course present at the funeral, and a most impressive sight it was.

'The Cathedral clock struck four; the usual merry peal of bells for evening prayers was silent. I strolled towards the Cathedral, and finding a side door open, walked in. The dull, harsh, and grating sound of the workmen filling up the grave struck heavily on my ears as it resounded through the body of the church. The mourners were all gone; and alone at the head of the grave, watching racantly the busy labourers, stood the white-headed old verger; another hour, the ground would be all levelled, and the stones replaced over the master he had served faithfully so many years. The verger informed me that the ground now opened had not been moved for 200 years, and that a Dean had not keen buried within the precincts of the church for nearly one hundred years. Bearing these facts in inind, I poked abous among the earth which had been thrown out of the grave. I found among the brickbats and rubbish a few broken purtions of human bones, which had evidently been buried very many years; but, fastened on to one of the brickbats, I discovered a little bone which I at once 
pronounced not to be human. It was a little round bone, about the size of a large shirt-stud, from the centre of which projected a longish tooth-like spine, the end of which still remained as sharp as a needle, and the enamel which covered it still resisted a scratch from a knife. The actual body of the bone was very light and brittle, and a simple test. I applied showed that it had been underground very many rears.'

The bone proved to be a spine from the back of a large thornback, and gave rise to a meditation, pleasantly told, upon the monkish inhabitants of Christ Church in olden time; their fast days and fish suppers, and the kitchen midden or refuse heap of the monkish cook before the days of Henry VIII., on which this fish-bone had doubtless been thrown three centuries ago.

In 1856 he began to write regularly for the 'Field' newspaper, and continued to do so until 1865.

$\mathrm{He}$ continued occasionally his experiments in casting, as his Journal shows :-

'June 18, 1855.-Made casts of rats, \&c., in lead.

'May 8, 1856.-Modelled the mare's head in clay from drain.'

The mare had died, and was partly dissected in the stable-yard.

'Where is the surgeon-major?' enquired the colonel on the day of the dissection.

'Inside the charger, your honour,' promptly replied the sentry.

On August 16, 1856, his father, Dean Buckland, died, and was buried at Islip.

'I felt the blow very much, standing over the zrave.' 
The sale of the Dean's library and private collection gave much occupation at the end of the year 1856 and during 1857. The geological collection had been given to the Oxford University and forms the chief part of the Geological Museum there.

In 1857 the first series of ' Curiosities of Natural History,' collecting and enlarging articles already written, was published by Bentley.

The originality and lummour of the book, the odd yet varied stores of information, and droll fertility of illustration made it at once popular, and established his reputation as an author; several successive editions rapidly followed each other.

Other literary work was continued, facile in style, ret prepared with much pains, by field observation and museum study, as these extracts from his Diary show :-

'January 3, 1857.-Went to Madame Tussaud.

'Account in the paper' about my putting my head into the guillotine.

"January 14. - Wrote to the "Field" about malformation in rabbit's mouth.

'Tanuary 22.-Colonel Ogilvie complimented me upon my letter to the "Field" about the rabbit's teeth, and said it was a pity that a man who could write like that should waste his time in the Life Guards.

February 8.-Dined at Mess. Lord Yarborough and others also dined. Afterwards gave a sort of lecture about the jack's head, coprolites, fish, \&c.

'February 10.-Went to Owen's lecture on the Anteater at the Zoological Gardens. Saw Owen, who fastened the article on Rats in the "Quarterly" on me. 
'February 16.-Went to see the whale at Whitechapel; not a very large one; only the skin, the bones all thrown away. Gave the man a lecture about it. Put him in the way of showing it at the Surrey Gardens.

'February 17. - Wrote article on the Whale.

'Felmuary 19.-To College of Surgeons to see Quekett about the whale. Made notes at the College.

"February 21.-Finished article on Whale and took it to "Household Words."

"March 20-21.-Read much in Athenæum about rats, \&c. 'To College of Surgeons, Bush's lecture. Took notes of rats at the College. Finished article on the Greological Auction for the "Quarterly."

'April 12.-St. Leonards. Went out before breakfast at low tide; found a few things; plenty of doreys; peculiar markings in the sand, very curious. After breakfast out with Quekett along the shore; picked up several cuttlefish and made interesting observations; with Daubeny and him to call upnn the Dean of Ely and upon Sir Woodbine Parish. Curious markings in sandstone examined.

'May 13.-Bought virarium at Covent Garden for $1 l$.; fitted it up with lizards.

'May 20.-Made skeleton of adder's head all the morning. Took the puff adder in a basket to the College of Sinrgeons; inoculated a bird and a guinea-pig with the poison from the dissected puff adder. All the morning made out the poison apparatus beautifully.

'May 23.-Worked all the day at the boa constrictor, inflating his intestines. Mr. Stone gave me wourali poison (used by South American Indians to poison arrows shot from their blow-pipes). 
'May 27.-Poisoned the thrush with wourali.

' May 31.-Tried experiments with the wourali poison on two frogs; they died wounded in the leg, but it required several minutes to kill them. This poison placed on the skin did not affect them at all.

'June 2.-To Weybridge to see Lady Easthope : found curious larvæ of dragon-fly on the posts and bushes; caught one half out, another quite out. Numerous ants' nests and eggs. Saw one viper, but could not catch him.

'June 11.-To the College; took dragon-flies and cases there.

'June 14.-Lunch with Lady Ogilvie. Frogs for lunch; vel'y good.

'June 29.-Dined with Bentley. Met there Hans Christian Andersen, the Danish poet and novelist; also Charles Kean's manager, and Dr. Doran. Pleasant party.

'July 6.-To Cremorne Gardens to see an exhibition of magnetism. Young girl twelve years old magnetises her brothers; great humbug; examined the people when in magnetic state; not uniformly stiff. The iron-lifting done entirely by knack. The people go determined to believe what they see.

'July 10.-To see the nondescript or hairy woman at Regent Street Gallery; her face is covered with hair, also her arms and body. She is apparently a Mexican.

'July 11.-To the College; worked hard collecting material for article on the hairy woman.

' July 15.-Finished article on Julia Pastrana, the hairy woman.

'July 22.- Spent two hours at the College of Surgeons working up article on Fish, \&c. 
' August 30.-Drove down to Professor Owen, met there a Russian colonel of engineers, walked in the park, found lizards with their branchiæ and a hare with ticks behind his neck. Professor. Ower gave me a tarantula in its nest.

' November 2.-To Ratcliff Highway. Saw Jamrach's tiger and little elephant and bears, and a tub full of tortoises.

' November 3.-To Millwall to see the big ship Leviathan launched. She unfortunately stuck fast, one of the chains having broken, and the stern going down farther than the bows.

' November 28.--To Portland. Walked up all over the quarries; found a man to lionise us, got from him and the quarries a capital section. Saw several fossil trees, but few birds'-nests (fossil Zamia). Saw a hollow with ox bones in it, all pretty perfect.

' Novemlier 30.-Poor dear mother died at St. Leonards at 11 P.M.

' December 12.--Made notes for poor man's market.

'December 15.-Called upon Quekett. Letter from "Field" wanting me to write weekly for them.

'December 17.-My birthday. Thirty-one years ago, at 6 A.M., I came into the world at the old house in Christchurch Quadrangle. I am now about half-way across the stage of life, and thank God I am just beginning to feel my feet. But oh! what I have lost since last birthday, the best friend a man can have in the world, his mother.

'December 21.-Dissected mole with view to papers in the "Field." 
'December 26.-Weighed roe of jack; 4.2,4.50 eggrs in it. Wrote to the "Field" about it."

In February 1858 Frank Buckland gave his first lecture at the South Kensington Museum, on Horn, Hair, and Bristles, being one of a series of six lectures addressed to working men.

'February 4, 1858.-Drove about collecting things for the lecture. Hope it will go off well, but it is hard work this mental and bodily labour.

' February 5.-In dog-cart nearly all day collecting things.

'February 6.-Drove to the Museum to get things out of the cases.

' February 8.- My lecture at South Kensington Museum on Horn, Hair, and Bristles. Did not get the room till three, and then only got two carpenters to help me; was tired, in consequence, before the lecture began. The room quite full, but when I came out to lecture I could see no one. Rather nerrous at first, but they tell me I did well, and was amusing as well as instructive. Of course I want practice. A heap of people there, who all said they were much pleased. Received many congratulations afterwards. Am thankful for success.'

The Diary of 1858 also mentions his breakfasting with Mrr. (now Sir) Lyon Playfair to meet Dr. Livingstone; being introdnced to Lord Palmerston by Sir Roderick Murchison, at the Jermyn Street Museum, and lunching witlı George Stephenson.

On May 6, 1858, Frank Buckland visited Paris for a week; his notes differ widely from those of the ordinary 
tourist. 'Saw a wonderful number of rats in the streets. 8th.- Went to the Jardin des Plantes, and over the galleries of zoology; wonderful place. 9th.-Went to the races in the Bois de Boulogne; saw the Emperor; Englishmen cried hurrah! Frenchmen could not make it out at all. 12th. - Went to the fish-market to buy frogs. To the Jardin des Plantes; saw there M. Milne Edwards, and heard a lecture. Bonght lizards. 13th.-Left Paris at 8; home by 10.30. 14th.- Sorted edible frogs, green treefrogs, and lizards, of which I brought home fourteen from Paris.'

The frogs and lizards he exhibited on his homeward journey, turning them loose in the railway carriage for the amusement of some friends who happened to be his fellow travellers, but to the doubtful enjoyment of the ladies of the party.

The literary work of 1858 included eighteen papers on various subjects, a second and third edition of 'Curiosities of Natural History,' and a new edition of Dean Buckland's 'Bridgewater Treatise,' in which he received valuable assistance from Professor Owen and from Professor Quekett, who had succeeded Professor Owen as curator of the Museum of the College of Surgeons.

The Diary frequently mentions ' worked hard at Bridgewater.' In result a very perfect edition was produced of this treatise, which forms the best literary memorial of the Dean, and which was framed on such broad lines as to be of permanent value, notwithstanding the time which has passed since it was written, and the rapid expansion of geological science. 
Professor Owen thus acknowledged the copy he received :-

'British Museum, Nov. 8, 1858.

'My dear Frank,--I found on my return here from the North the copy of the new edition of your dear father's "Bridgewater," and I like the look of it extremely.

'It accords admairably with the good old original in type and form, and gives a most useful and easily learnt account of the main facts in geology and palæontology.

'I look upon it as the best elementary book that a country gentleman or azure lady could take up for those sciences. It very honourably associates your name with that of your father.

'At a dinner at the White Lodge last Thursday the Prince of Wales told me he had been reading with much pleasure your book on Natural History.

'Always truly yours,

'RICHARD OWEN.'

In 1858, lectures on 'The House we Live in' were given at the Mechanics' Institutes of Abingdon, Newbury, and Wantage, and at Windsor. At Abingdon the 'lecture lasted from 8 to 10.30 ; found it very hard work; managed to make the people laugh; congratulated afterwards by many people, high and low.' At Windsor ' there was a good audience; gave a very lame lecture. In future I must not look at notes too much before lecturing. At Wantage did not look at all, and gave a better lecture.' 
In November 1858, Frank Buckland received an 'offer from Mr. Brunel to go to Egypt with him, all expenses paid and a guinea a day besides from 4th December to March. Went up to London and had interview with him and Lady Hawes. Promised Brunel I would go with him, if possible. Colonels Martyn and Vyse both gave me leave to go to Egypt if I liked. 18th.-Letter from T. (surgeon to Second Life Guards) saying it would put him to great inconvenience if I went; so I wrote and refused Brunel's offer, feeling I was doing my duty towards my neighbour, and this was my motive.' 


\section{CHAPTER VI.}

THE LIFE GUARDS, $1859-1862$.

THE year 1859 was marked by the search for, and ciscovery in the vaults of St. Martin's in the Fields of, the body of John Hunter, the father of modern physiology, and founder of the Hunterian Museum of Comparative Anatomy at the College of Surgeons. For him Frank Buckland entertained an enthusiastic admiration, calling him the greatest of Englishmen.

A centenary dinner, in October 1856, had commemorated the studentship of John Hunter at St. George's Hospital. From that time Frank Buckland formed the resolution, which he now carried out, of doing honour to the remains of the great anatomist, interred sixty-six years before at St. Martin's in the Fields.

The search, after such lapse of time, was no light or agreeable task, nor free from risk to health, and in result he narrowly escaped a serious illness; but he set to work with his usual determination, one of his maxims being, 'Must not shrink from doing a thing at first sight disagreeable, or nothing will ever be accomplished. Nothing like determination and perseverance.'

Accordingly, on January 26, as the Diary shows. he 'went to St. Martin's Church, and found out the registry of John Hunter's death. Down into Vault No. 3 to 
look for the coffin; wrote letter to the President of the College, Mr. Green, about it. 29th.—To St. Martin's Church; again down into the catacombs with man, who recollected moving the coffin in 1832.

'Felmuary 1.-To St. Martin's Church to look for John Hunter's coffin.

'February 7.-Began to look for John Hunter's body at 1 P.M. ; moved coffins all day long; turned out about thirty coffins, many very curious ones among them. The stink awful ; rather faint towards the end of the business.'

So he continued searching in the vaults for fourteen days without success; but on February 22 ' found the coffin of John Hunter. At work all the morning, and about three in the afternoon found it, the bottom coffin in the last tier but one; gave a shriek of delight at finding it. It is in excellent condition, and the letters on the brass plate were as perfect as the day they were engraved. "John Hunter, Esq., died October 16, 1793, aged 64." So my perseverance is rewarded at last. Went with the news to Quekett and Mr. Arnott, who both of them came after lecture to look at the coffin. 23rd.-Down into the vaults with Mr. South and Mr. James, his assistant, in the afternoon; then again with Professor Owen, who expressed himself much pleased. I wish I could have made a sketch of him, with his hand on the coffin, looking thoughtfully at it: it would have made an excellent subject. Much used up at night.'

A few days afterwards he 'felt quite knocked down and prostrate; thought I was going to bave fever; shivering pains in the back, headache, shortness of breath, \&c. G. and $R$. came in and prescrbed for me; thought $I$ was 
going to have a serious attack.' The attack passed off under treatment, and on March 28 he attended the solemn re-interment of the coffin in Westminster Abbey, and on the following day was invited to sit with the Council of the College of Surgeons, to consider the erection of a memorial to John Hunter. 'Green made splendid speech; President of College of Physicians next to him. Introduced to Mr. Lawrence; Stanley very polite. A great honour to be sitting at the Council at my age among people so much my seniors.'

A marble statue was afterwards placed in the College of Surgeons, and a scholarship for comparative anatomy founded.

The search at St. Martin's and the ceremony in the Abbey are fully described in 'Curiosities of Natural History.' ' The Leeds School of Medicine presented him with a silver medal 's a mark of respect for his exertions in placing the body of John Hunter in Westminster Abbey.

The following entries occur in the Journal for 1859 :

'April 28.-Dined with the Dean of Westminster; after dinner, gave a sort of lecture to the people assembled on the gorilla, and on the Whitechapel whale.

'May 6.-To see the whale at Gravesend, a specimen of the rorqual; Ur. Murie of the College with me. Took the measurements of him with great care, and some danger from the slippery carcass.

'The total length was 56 feet, supposed weight about 45 tons. We were very anxious to get upon the body of the whale; and just as we were doing so we were stopped by the master's exclamation, "Don't get on the top of

1 Third series, vol. ii. p. 159. 
him; you might bust him." However, we overcame his scruples, and with some difficulty climbed up. It was hazardous walking, as the skin had all become loose and very slippery from decomposition; and there was not a little danger, as the tide was running down fast on all sides of this gigantic mass of flesh, which felt under the feet like a mountain of highly oiled india-rubber.

' 9 th. -Down to village of Greys, near Tilbury, with Dr. Marie, to dissect the whale. Murie and I cut off various parts for dissection; took home a bit of the flesh to eat, but found it too strong, even when boiled with charcoal.

' July 9.-To British Museum to see Agassiz, with Owen, Lord Enniskillen, and Sir P. Egerton. M. Agassiz much pleased with the fossil fish in the Museum.

'10th. -To Hampton Court; observed that Raphael has painted a skate, a gar-pike, a dog-fish, and a haddock in the picture of the Miraculous Draught of Fishes.

'25th-Made agreement with Mr. Crockford, of the "Field," to answer questions, \&c., in the "Field."

In this year he lectured twice at Windsor, and also lectured at Burnham on men and animals. 'Audience principally working men, and their wives and babies. I lectured pretty well, but, as usual, had too many things to show.'

His literary work increased to sixty-three articles on multifarious subjects, which appeared this year in the 'Field' and 'Leisure Hour.'

The Acclimatisation Society, though formed somewhat later, had its origin in this year.

'On January 21, 1859, I had the good fortune,' he wrote, ' to be invited to a dinner, which will, I trust, here- 
after form the date of an epoch in natural history; I mean the now celebrated eland dinner, when, for the first time, the freshly killed haunch of this African antelope was placed on the table of the London Tavern. The savoury smell of the roasted beast seemed to have pervaded the naturalist world, for a goodly company were assembled, all eager for the experiment. At the head of the table sat Professor Owen himself, his scalpel turned into a carving lnife, and his gustatory apparatus in full working order. It was, indeed, a zoological dinner to which each of the four points of the compass had sent its contribution. We had a large pike from the East; American partridges shot but a few days ago in the dense woods of the Transatlantic West ; a wild goose, probably a young bean goose, from the North; and an eland from the South. The assembled company ardent lovers of Nature and all her works: most of them distinguished in their individual departments. The gastronomic trial over, we next enjoyed an intellectual treat in hearing from the professor his satisfaction at having been present at a new epoch in natural history. He put forth the benefits which would accrue to us by naturalising animals from foreign parts, animals good for food as well as ornamental to the parks.

"The glades of South Africa have been - described by numerous travellers as reminding them forcibly of the scenery of many of our English parks, and here were the first-fruits of the experiments as to whether the indigenous animals of these distant climes would do well in our own latitudes. The experiment was entirely successful, and he hoped wonld lead to more, and that we might one day see troops of elands gracefully galloping orer our green 
sward, and herds of koodoos and other representatives of the antelope family which are so numerous in Africa, enjoying their existence in English parks, and added to the list of food good for the inhabitants of not only England, but Europe in general.

'The vice-chairman, Mr. Mitchell, (Secretary of the Zoological Society, ) then instanced the case of the Indian pheasants, already in course of naturalisation at several places in England, and expressed his conviction that the American partridges we had just partaken of, as well as the European gelinotte, would thrive well in our woods and copses, particularly in Kent, and that there could not be any great difficulty in getting them over from America for this purpose. Elands, since the present experiment had become publicly known, had risen in the market, the demand much exceeding the supply, and there were numerous applications for them which he was sorry to say the Zoological Society could not meet. There were, however, plenty more elands in South Africa, to be had for the trouble of importing them; a fiesh supply was much wanted, and he trusted that this subject might be taken up by those who had convenient pasture-ground for them in England, and would be patriotic enough to further the important cause of the acclimatisation of useful exotic animais in English parks and homesteads.'

Professor Owen, a few days afterwards, wrote a letter to the 'Times, speaking highly of eland as a meat and advocating the cause of acclimatisation. His observations, both spoken and printed, made a deep impression on Frank Buckland; 'for they showed us how science, even in her gravest moods, tends to utility, and that there was a 
grand uncultivated field open to those who would take up the subject in earnest.'

In January, 1860, a remarkable article, in the 'Edinburgh Review,' upon the acclimatisation of animals, attributed to Mr. Mitchell, again drew attention to the subject, and in result Frank Buckland determined to form in England an Acclimatisation Society.

In Paris, a Société d'Acclimatation had been formed, in 1854, on an international basis, under the presidency of M. Isidore Geoffroy St. Hilaire, and now numbered more than two thousand members, including in its roll thirty-five royal names, from the Emperor of the French to the King of Siam, from the Sovereign Pontiff to the Emperor of Brazil ; and it possessed a garden thirty-three acres in extent, and every convenience and appliance for carrying out its principles.

The French society was in active operation, having local societies affiliated to it, and publishing monthly reports, and had offered, in 1857, a series of prizes for the introduction into France, and her colonies, of various beasts, birds, fish, insects, and plants.

We are apt to forget how large a portion of the animal and vegetable food of this country has been introduced from abroad; the same process is always going on, slowly in this country, already well stocked, rapidly in our colonies, of which the transformation of Australia, in a few years, from barrenness to fruitfulness, both in animal and vegetable food products, is the most striking example. In England it is said that but four additions have been made to our domesticated animals since the Christian era; riz. in 1524, the turkey, in 1650 the musk-duck, in 1725 the 
gold-pheasant, and in 1740 the silver-pheasant; but 'the turkey alone,' exclaimed Frank Buckland, 'is an answer to the question of the sceptic, who believes we have the best of everything; and, if he be a gastronomer, I appeal to that love of good feeding, which we all have more or less, and ask him, if it were not for the acclimatisation, which took place in 1524, what would he have for dinner at Christmas to face his roast beef?'

Frank Buckland aimed to make science practical. To find out a new kind of food, or to multiply an old one, was to do practical good to a hungry people; and to this end he henceforward devoted his chief energies.

The new society was formed with this object; he undertook the duties of organising secretary. The first meeting was successfully held on June 26, 1860.

In 1860, the second series of 'Curiosities of Natural History' was published, and a fifth edition of the first series; thirty-three articles on various subjects also ap. peared.

He devoted increased attention to the Zoological Gardens, where he became a voluntary consulting surgeon, doctoring the sick, and assisting in the dissection of the deceased animals.

Ever increasing his own stores of knowledge, he attended the lectures of Professor Owen on fossil mammalia, of Dr. Lankester on the uses of animals tn man, and Professor Quekett's biological lectures.

He continued to take part in the meetings of the Committee of the Council of the College of Surgeons for the memorial to John Hunter, and worked up the Acclimatisation Society. 
In August he went to Scotland, writing in the train the index to the first series of 'Curiosities.' On the 21st he had his 'first day's salmon fishing.' Always an ardent fisherman so far as leisure allowed, he used to say that the happiest moment of his life was when he caught his first salmon.

He saw Carlisle, Glasgow, Perth, Edinburgh, Danbar and Berwick, taking notes wherever he went for future use.

'At Chillingham Castle, the Earl of Tankerville took me out on a pony, to see the wild cattle in the park: long conversation with him.'

On November 27 he read a paper before the Society of Arts on the acclimatising of animals, Professor Owen being in the chair. After enforcing the example of the French Society, whose learned president had stated that the world furnished a list of no less than 140,000 animals, out of which vast catalogue we limit our attention to 43 , he proceeded to examine into this catalogue of animal life, and described, not at random, but guided by the experience of the Zoological Society of London, those among the numerous individuals composing it, which were most likely to be of future use to us, enumerating those animals and birds which from actual experience have been proved to thrive in this country and also to multiply their species, there being no reason why, having once bred, they should not breed and multiply again.

The endeavour by acclimatisation to vary and increase our supplies of food, drew his practical mind to consider the still greater value of our native sources of food. Whatever might be the result of the endeavour to introduce 
new animals useful for food, the preservation and multiplication of the native fish supply of the country was, he clearly saw, an object of national importance, and he began in 1861 to devote his energies to it.

At this date, although in France and Germany the artificial culture of river and sea fisheries had been for some time practised, and in China for generations, in England it was little known. Most people are now familiar with the apparatus by which the natural conditions of fish-hatching are imitated. A box nearly filled with fine gravel represents the bed of the stream in which the eggs are deposited, the gravel being first boiled, to destroy creatures which might also come to life and prey on the ova. Running water, as in the natural stream, is supplied from a cistern placed above the box, from which, through a half-turned cock, a small stream of water constantly dribbles. To enlarge the model river bed, a series of boxes are placed like steps, one below the other, the tiny stream of water trickling in turn from one to the other; running water being essential to keep the eggs alive, yet must the stream be so gentle as not to disturb them on their gravelly bed.

In the eggs, which resemble small whitish semi-opaqne beads, presently two black specks appear, which develope into eyes, and in due time the egg bursts and the embryo fish uncurls, half an inch to one inch in length, with large eyes, closed mouth, and a transparent pouch of nutriment hanging underneath the throat, to be gradually absorbed in about six or eight weeks, when the month opens, and feeding by that organ begins.

Frank Buckland used to liken the absorption of this 
long pouch to the process he had observed in human babies, which at first appear with an appendage of long clothes, gradually absorbed as they are short-coated, when they open their mouths and begin to eat and drink like their elders.

On May 1, 1861, Frank Buckland first collected perch spawn, at Surley Hall, Eton, for artificial hatching, which he commenced in his own house, and threw himself into his new pursuit with an enthusiasm always contagious. In a few days there were 'lots of men in my rooms looking at fish-hatching:' He was immediately elected upon the committee of the Thames Angling Preservation Society, whose chairman, the late Mr. Stephen Ponder, entered heartily into his schemes for fish-culture. He was also placed on the council of the British Fisheries Preservation Society. On May 13 he took up the live perch, just hatched, to the meeting of the former society, and 'created a great sensation.' On May 15 he 'collected much perch spawn.' Fish-hatching boxes were soon afterwards constructed at Mr. Stephen Ponder's residence at Hampton, in which the perch spawn was placed and carefully watched. Success was only obtained by conquering failure. At first the enemies of the ova were hatched out with them and devoured them. The gravel was boiled to destroy eggs and larvæ of destructive insects, and with increasing experience the fish were safely reared.

On Christmas-day the first salmon ova were placed in the boxes at Hampton.

' December 24.-Up to London in afternoon to fetch some salmon spawn sent by Mr. Garnett of Clitheroe: brought it home and placed it under the tap after dinner. 
25th. Found that the tap over the salmon ova had run dry. Went off immediately to Hampton and back ; fearfully cold, but never mind that.'

He contiuued this jear to attend Professor Orven's lectures, wrote numerous articles, and lectured at Windsor, at Witney, and at Oxford. His lecture at Oxford was thus described by one of the leading daily journals :-

'One of the most interesting, amusing, and instructive lectures that have ever been given in Oxford was delivered at the Town Eall by Mr. Frank Buckland, M.A. Ch. Ch. and son of the late Dean Buckland. Apart from the interest which, as might be expected, is attached to one bearing a name so cherished here, the celebrity which the son has attained as the writer of some of the most fascinating works on natural history had the effect of gathering round him a large and attentive audience. The subject was the Curiosities of Natural History, and when the lecturer presented himself, he was greeted with much applause, which was renerred when he stated that for all the pleasure he had derived from the study of the works of nature, and had been able to impart to others, be was indebted to his late father, who had fostered and encouraged the taste which he had always had in that direction.

'The lecture itself embraced a large number of interesting and curious facts relating to man civilised and savage, elephants, mammoths, lions, tigers, hyænas, rats, snakes, spiders, caterpillars, birds, -insh, oysters, pearls ; all of which were illustrated and made more palpable by skeletons, skulls, relics, and specimens, obtained from various quarters, and some of which were of a most costly nature. For two hours did the lecturer dilate upon these objects, with 
a combination of instruction, wit, and humour which at the same time interested, onlightened, and amused the audience, who testified their delight by frequent bursts of applause. The warmth of feeling which Mr. Buckland threw into his favourite study, the colloquial and pleasant manner in which he narrated facts and incidents, and his readiness to allow his specimens to be inspected and examined by the audience, gave the lecture additional interest and amusement, and recalled very forcibly to the recollection of many present the late Dr. Buckland, who was endowed with the same powers and generous characteristics.'

Some notes have been preserved of the Windsor lecture, of which Teeth formed the chief subject; but these are but a shadow of the vivacity of the lecture in which every subject touched on was made visible to the eye by illustrative specimens.

'My object,' he said, 'is to induce thought, comparison, inquiry; using plain language and avoiding hard names, which often hinder instead of belping the acquirement of useful knowledge. A scientific meeting is not necessary to scientific or natural research. The book of nature is open to all.

'The stone quarry and the gravel pit, as well as the ruined castle or ancient mound, are fraught with lessons of history. Natural history is easy to learn; did we but keep our eyes open daily and hourly, from all around we might gain instruction and amusement.

'The first thing we must look at in an animal to ascertain its order, is its tooth. From the nature of the teeth the geologist ascertains the complete structure of the animal. These may serve to group together the objects of the lecture. 
- Beginning naturally with our own species: People do not think much of their teeth until they get the toothache, and then begin to wish they had taken more care of them. I'he front teeth are for biting. The back teeth for grinding. Eating hard substances renders the teeth smooth. In the skulls of Danes and Saxons the teeth are exceedingly smooth from this cause. So in the case of a skull of a Caffre who harassed the rear of our army, and was just on the point of shooting a friend of mine, when he shot the Caffre instead, and kindly presented me with his skull.' Next a tattooed skull of a New Zealander was exhibited. 'Soon after the discovery of these tribes by Captain Cook there was such a traffic in these skulls among the sailors that the natives used to kill each other for the purpose of selling the skull of the victim, for which from $8 l$. to $9 l$. was sometimes given. This traffic is now happily abolished and the skull is a rare specimen. Notice how beautiful is the tattooing; the artist seems to have imitated the graining of the root of a tree; as in one of their paddles they seem to have taken the section of a palm-tree for the pattern. The doctrine of following nature's pattern, which these savages seem ever to have considered, Mr. Ruskin is now beginning to teach us. Passing from them to the most intelligent of beasts, the huge elephant's tooth is unlike a man's tooth and made for grinding, not biting. Elephants do not eat beef-steaks and mutton-chops, but with their wonderful trunks pull down branches and tear up trees by their roots, and crush whatever they take within their mouths between the teeth, which are like an immense grinding mill. There are two kinds of elephant, the African and Asiatic, easily distinguishable by their teeth, which are 
divided by sectional lines of hard enamel, which in the Asiatic run straight across, and in the African diagonally in diamond shapes. If I tell you that elephants such as these once lived in the neighbourhood of Windsor, and came down to the river side where the bridge now is, you may be astonished; yet such is the fact, else how came this elephant's tooth in the quarry at Burnham, where it was dug out? In tertiary times before the time of Man, these animals did exist here, and their remains are constantly found. There was also the fossil ox, and any person interested who will go with me to the quarrymen at Maidenhead, and stand a glass of ale, may get plenty of bones of fossil oxen, which are there in abundance, as also those of the hippopotamus, which lived in those days on the banks of the Thames as plentifully as water-rats now. The pigmy elephant also was there, for its teeth are found. There is now a great deal said about Man being contemporary with the mammoth elephant, flint arrow-heads having been found with the bones of these animals. The question is, did Man live at the same time? a subject of noment, which anyone who finds these flint arrow-heads, and carefully notes their position and accompaniments, may be able to illustrate.'

Passing to the monkey tribe, he described the gorilla; then showed the skull of a tiger, which had had a man in its mouth, and carried the token of retribution in a bullet-hole. Of the lion, he said, 'the most dangerous thing is its fearfully crushing paw. When a man was lately killed by a lion, at Astley's, I went soon after to see the lion, and found that the man had very foolishly run away instead of facing the lion; the lion just patted 
him on the back with his paw, and he died in an instant. The tongue of the lion is rough, like that of a cat, in order that it may scrape off the flesh from the animals it kills; then afterwards come the hyænas and crunch the bones. Anyone visiting the Zoological Gardens would be attracted by the roar of the lion. An examination of the larynx shows it to be a most perfect musical instrument, resembling in its anatomy a trombone. There is behind the larynx a vibrating machine, which produces the sound by which all other animals are awed: a roar, a spring, and a pat with his powerful paw, and they are dead. The lion, like the cat, has a beantiful bunch of whiskers, which it distends whenever it takes a spring, and the moment the end of the whisker touches the least obstruction, a telegraphic message goes to the brain, "Keep to the right, or keep to the left," and the body follows. Our whiskers are not so useful, only ornamental.'

He then described the poisonous teeth of the rattlesnake, and of the viper, the only poisonous snake in England. ' It is said that the viper's young take up their abode in the stomach of the mother, running down her throat. This is strange, if true; but scarcely more so than the maternal kangaroo putting her young ones into a pocket in her stomach, which may be seen at the Zoological Gardens.' He then showed the large teeth of the voracious spermaceti whale, whose oil and ambergris are articles of commerce. He had always thought the ambergris was a secretion from the whale; and if it were, as the whale devoured the cuttlefish, there should be the remains of that fish in the secretion. Seeing a piece of ambergris in the shop of Messrs. P'iesse and Lubin, the perfumers, he examin ${ }_{\theta d}$ it, and 
found in it the beaks of cuttle-fish, proving his belief correct. Ambergris, though rather disagreeable in itself, is used in the manufacture of scent, and if added to eau de cologne or lavender water, adds twenty-five per cent. to its value. Teeth of fish were then shown and described: the shark, the skate, the jack; and then the tooth-like tongues of shell-fish, with which the whelk, and other like shell-fish, pierce the thick shell of the oyster: to combat this attack, the pearl oyster fortifies the breach in its shell with a barrier of pearl, and thus the pearl is formed so valuable to jeweller's and ladies. 'Thus, then,' he concluded, 'I have endeavoured to point out to you some of the curiosities of natural history - I should rather say of the wonders of nature; but I have not made mention of a huge volume of facts which might be opened with advantage: I mean the uses of animals in relation to the industry of man, a volume full of most interesting results and experiences, not, however, by any meaus yet exhausted. There are deductions most interesting and most important to be made from the study of natural history. When we consider the ordained position of Man, as lord of the creation aud of created things, it is indeed surprising how few there are who open their eyes to take cognisauce of the wonders which surround them. The earth is full of God's handiwork. Whether we examine the leaf of the hedgerow that falls at our feet, or humble worm which feeds upou that leaf; whether we contemplate the giant elephant or the lordly lion roaming free and unfettered in the primeval forests of tropical climates; whether we consider the soft spring wind, as it brings health, and life, and growth to the nascent green carpet of the earth, or tremble at the 
Divine artillery of the awful thunder, or whether we examine and reflect upon the admirable construction of the frame of Man, with all its beautiful contrivances, the culminating point, the very perfection of the animal kingdom; shall we not be struck with the thought that these things were not made in vain, that there must be an Omniscient Mrind, which in infinite power and wisdom cares for the well-being of all His creatures, small and great? Shall we not have weapons of the most irresistible kind, wherewith to combat infidelity and the theories of those men who imagine they can, with their limited faculties, by notions of chance or mere properties of matter, explain and account for the actions of the great Creator? Shall we not at once become sensible of that privilege, which we are so apt to use without due thankfulness to its Giver, who has allowed us, with our imperfect senses, to contemplate and consider His perfect and beautiful works?'

'We know not,' said a critic of the lecture, 'which most to admire, the felicity of diction which made the most abstruse subject familiar to the junior portion of the audience, the intellectual excitability which awakened the attention of the more profound and learned members of the Society, the exquisite specimens which were ready to his hands to exemplify his scientific deductions, or the rich vein of humour and interesting anecdote with which the production of each specimen was so happily illustrated.'

The story of vipers swallowing their young, alluded to in the lecture, was never credited by Frank Buckland, 
though a subject of frequent discussion. Numerous vipers were kept for observation until their constant escape (due to the uncontrollable curiosity of John the page) led to their final transfer to the Zoological Gardens.

Some of his experiences with snakes he thus narrated :-

' When medical officer to the Second Life Guards, I tried various experiments with vipers. I was anxious to obtain a living specimen of a then new British snake, the Coronella lavis, so I engaged a professional viper-catcher, one White, to collect for me. I sent him down to the New Forest with orders to catch every living snake he saw-the common ringed snake (Coluber natrix) excepted. In four days he returned with a bag, and told me he had had capital sport. We went into an empty barrack room, and standing on a chair I unloosed the top of White's bag, and shot the contents on to the floor: the slippery reptiles came tumbling out, first singly and then in pairs, and at last the main body, coiled and twisted together into a solid mass, like Medusa's chignon; and in half a minute I had on the floor of the room fifteen vipers and two coronellas, crawling about in all directions, and looking as savage as vipers can look. The first thing I did, was to pick up the coronellas and put them carefully away; and then we had to catch all the vipers again. White gare me a lesson in the noble art of viper-catching, which, like playing the fiddle, seems very easy to do, but in reality is a somerwhat difficult, if not perilous operation. Taking a small but strong bit of thin stick, he singled out a viper and then pressed the stick tightly on his neck. When he saw the stick had a fast hold (it was not a forked stick), he canght 
hold of the viper's neck between his finger and thumb, and lifted him off the ground; the viper slashed his tail about, like a loose halyard in a gale of wind, and then twined his body round White's hand. After a while, the beast was quiet, and I was able to examine him. His mouth was wide open, and his tiny glass-like and needle-pointed fangs were "full cock" like the lock of a shot gun. I then tickled his nose with a feather, and immediately learned something I did not know before: my irate friend moved his fangs alternately, first one becoming erect and then the other, and this in quick succession, just like a man sparring at the commencement of a fight; he never moved them both simultaneously, and no poison came out of the fangs. I then got a glass slide out of the microscope, and placed it in the viper's month ; in an instant both fangs struck down upon it, and were immediately retracted parallel with the gum-their normal position when at rest. The fangs struck the glass with the quickness of a bee's sting, and seemed to attempt to fusten on it with a spiteful earnestness. Upon taking away the glass from between the viper's jaws, I was delighted to observe two drops of perfectly clear translucent fluid resting upon it, each drop corresponding to the place where the tooth had struck. I at once placed these drops under the microscope, and then saw a wondrous sight. After a second or two, on a sudden, a crystal-like fibre shot across the field of vision, and then another and another, these slender lines crossing each other at various angles, reminding me of the general appearance of an aurora borealis, or of delicate frost crystals on a carriage or room window, when there has been a sharp touch of 
frost. I was so delighted with this novel and unexpected phenomenon, that $I$ ran at once into the mess-room and called my brother-officers to look into the microscope; but though I could not have been absent from the room a minute, when we returned the coruscations and the crystallisations had entirely disappeared, and nothing but a pure fluid could be seen.'

On July 12, 1862, the inaugural dinner of the Acclimatisation Society was held at Willis's Rooms, the delicacies and difficulties of which Frank Buckland thus described :-

'Well, I am glad it's over at last. I can now, for the first time, fully appreciate the horrible state of excitement which is for the most part displayed when "Materfamilias" is about to give a "party;" be it dinner or dancing, the good lady has little to do, compared to the work of the unfortunate secretaries who had the getting together of the numerous new, and I may say extraordinary, dishes which were put on the table. First, then, under the head of "Potages," was "Birds' nest soup" - esteemed a great delicacy in China. The nests are built in caves along the rocky coasts of China, Java, and Sumatra, by a swallow (Hirundo esculenta). The market price of the best nests in China is nearly twice their weight in silver. This soup was the cause of much and dire anxiety to me; at the last moment the gentleman who had promised them failed me, and it was only through the great kindness of a friend that we got the soup at all. He gave me four nests, and the cook cleverly made nearly a quart of soup from them; they are formed of a species of gelatine which is soluble in boiling water, the soup therefore tasted 
gelatinous, but with a very peculiar and not disagreeable flavour. Next we had soup of "Tripang or Beche de Mer." This is a species of Holothuria, or sea slug, found in the Chinese and Japanese seas. They are worth about sixpence each in China, and are said to be a most succulent and pleasant food, not at all unlike the green fat of turtle. These Tripangs, too, caused me much anxiety; when I first received them they were as hard and solid as a bit of horse's hoof. I gave them to our regimental mess cook, and they were soaked all day and boiled all night; the next morning when we looked at them-lo and behold !these dry masses had swollen out into huge, long, blacklooking masses amazingly like the common black garden slug. I cut them up into small pieces instantly; for if their appearance had then been made public, none of our guests, I am sure, would ever have touched them. These bits were boiled and simmered, I am afraid to say how many hours-the cook and I thought they would never get soft. However, they were soft by the time they were put on the table, and they were-well, if you please, capital; tasting something between a bit of calf's head (as in soup) and the contents of the glue-pot; excellent for a hungry man, and doubtless exceedingly palatable to John Chinaman, who does not know what turtle soup, real or mock, tastes like. Then followed "Nerfs de Daim" soup, made from the sinews of the Axis deer, which is esteemed a great delicacy, and even (according to Mr. Fortune) a royal dish, from Cochin China. 'These deer sinews took a monstrous deal of boiling, and they were simmering in the pot an amazingly long time; when served up they were good eating, but glue-like. I am now convinced 
that the Chinese epicures love gelatinous soups; for all these three soups were from China; and when I have to entertain a Chinaman, I shall certainly give him a gelatinous soup-say sixpennyworth of carpenter's glue, served for appearances' sake in an ordinary soup tureen. Then followed "Semoule soup, made from the flour of a wheat grown in Algeria." This soup was more fitted for invalids than for ordinary table soup; but it was very good, and reminded one of the porridge the giant was eating when Jack the giant-slayer killed him.

'After soup came the entrées. No one can tell the trouble I had in classifying many of our dishes, and the cooks and I had many consultations on the subject. However, "Kangaroo steamer" led off the entrées. It is a stew prepared with choice portions of the kangaroo, and is highly esteemed in Australia. The tin can given me was not over tight, and the consequence was, that the "Kangaroo steamer" was a little "gone off," but not bad for all that. Then came "Pepper Pot," a favourite dish in the West Indies, made of various spices, and it was most excellent; everybody wanted "Pepper Pot," and the waiters very nearly quarrelled over it in their anxiety to obtain supplies; and as I was helping it I was obliged to tap their fingers with the spoon, to keep them and their plates out of the way. Then we had "Chickens prepared with curry powder from Siam," and "Ris de veau," prepared with spices from Jamaica. I believe they were good, for they were all cut up and gone in an instant.

"After these followed the reléves, beginning with "One of the Society's Chinese Lambs, roasted whole, from 
Shanghai." Poor lamb, he was very innocent, and also capital eating, for his bones were in ten minutes picked as clean as if a flock of vultures had been at him. Then came "Kangaroo ham," rather dry (it had not been soaked enough), and very small; but it got a good character, for, by some mistake, the "Kangaroo ham" cards were placed with the dish containing "wild boar ham," and many of our guests were eating wild boar's flesh when they thought they had got kangaroo. Now come the rôts. Among these figured a "Syrian Pig," a "Canadian Goose," a "Guan," a "Curassow," and a "Honduras Turkey." These three latter birds are from South America, and were placed on the table to show what immense additions they would be to our tables as food, and everybody knows how ornamental they are in appearance. Then we had three couples of the peculiar duck bred by the Hon. G. Berkeley, namely, a cross between the wild pin-tail and the common duck, which combines the flavour of both birds, and will multiply like ordinary ducks. We had also three couple of "dusky ducks," and very good they were.

"The "Leporines" were kindly given me by Mr. Bartlett. They are said to be half rabbit, half hare; but as the test of the knife and fork had never been applied to them, I was most anxious that it should be used on this occasion; the verdict from both the roast and boiled specimens being that this animal has 90 per cent. of the rabbit in his composition.

'Among the entremets figured "sweet potatoes from Algeria," and Dioscorea Batatas from the branch society in Guernsey, both excellent, and promising well to be a 
great addition to the common potato. In taste they were like very good mashed potatoes, with a peculiar delicncy about them.

"Under the head of "Hors d'CEuvres," we placed on the table "Digby herring salad," the fish being from Nora Scotia, and "Botargo," which is the roe of the red mullet, dried and used as caviare by the gourmets of the Ionian Islands-both excellent, as the empty dishes proved. The dessert consisted of "Dried Bananas," from the Île de la Réunion (Bourbon) - a wonderful sweetmeat; "Preserved Bibas;" the fruit of Eriobotrya japonica (also from Bourbon), having a sweet acid and most palatable taste; "Preserved Cassareep" and "Guava Jelly," from Dominica; "Rosella Jelly," from Queensland-all very good and highly approved of.

'After dessert were presented : a new kind of coffee"Cassia orientalis," a new substitute for chicory-and a new tea called "Ayapana" tea, all from the Île de la Réunion, and all, I suppose, pretty good, as they were gone when I went, late in the evening, to get a taste of them. As for the wines and liqueurs, their name was legion. They came from Victoria, New South Wales, Queensland, Guadaloupe, Algeria, Ionian Islands, Martinique, \&c., the long row of empty bottles showing that the palates of the guests had approved of what was placed in their glasses.

'Speeches from the noble Chairman (Lord Stanley), and many influential gentlemen from France and Australia and our numerous colonies, of course, followed the repastadding a feast of intellect to a feast of the appetite. Thus, then, ended one of the most agreeable dinners (except that 
I and my co-secretary got nothing to eat till nearly twelve o'clock) I ever was present at.'

The author of endless merriment in his regiment, Frank Buckland was sometimes the unwitting cause of breach of discipline. One Sunday in 1862, at church parade, the men all burst out laughing, to the scandal of the colonel, who angrily appealed to the adjutant. The adjutant turning round roared with laughter, as did the sergeant-major. The colonel then turned, and beheld Frank Buckland coming out of his quarter's, attended by Brice the French giant and a dwarf then exhibiting in London, who, being like Frank, off duty on Sunday morning, had come to breakfast with him.

This giant, a huge but well-proportioned and really amiable man of about 7 feet 8 inches, was first found by Frank Buckland exhibiting himself in associations derogatory to his worth, and was advised to insist on better treatment or quit. 'But,' said Frank, 'I was soon cured of giving practical advice;' a few days afterwards a cab drove up, from which emerged the giant, who had taken the kind advice literally, had left his exhibition and appealed to Frank as his only friend to help him to a better livelihood; and not in vain (though few would care to have a giant thrown on their hands); he was cared for, and ere long started afresh under happier auspices.

After this Brice was a not unfrequent visitor, to the delight of the neighbouring youth, bringing a few years later his wife, 'a very agreeable, good-looking, chatty girl.' A pair of the giant's shoes, and a cast of his huge hand, were retained as keepsakes.

A lady dwarf was one day invited to meet him, but 
with untoward results; the good-natured giant took her up, as a little girl, on his knee, causing an explosion of indignation. 'I am nineteen,' she cried, ' and to treat me like a baby!' It was long before her ruffled dignity could be appeased. 


\section{CHAPTER VII.}

FISH CULTURE : 1863-1865.

Is 1860, the seniol surgeon of the Second Life Guards haring died, Frank Buckland applied for promotion. His application for the full surgeoncy was strongly supported by Lord-Seaton the colonel, and other officers of the regiment, and by Sir Roderick Murchison, Sir Benjamin Brodie, and other friends. According to the old tradition of the Guards, the medical officers were promoted as vacancies occurred in the same regiment, but, under new regulations, it was now proposed that promotion should go by seniority in the brigade, instead of in each regiment, or that the colonel might, if he chose, appoint a surgeon from the line; and it was decided at the Horse Guards to give the preference to an assistant surgeon of older standing from another regiment.

The disappointment of promotion in his old regiment, and the growing success of his literary and scientific career, led him, in 1863, to resign his commission after eight year's' service, and to devote himself to literature and practical natural history.

On leaving the army, Frank Buckland threw himself with renewed ardour into the work he had now chosen for life. 
There have been many scientific naturalists who have enlarged or classified onr knowledge of animal life. This was not the ideal Frank Buckland set before himself, so much as the practical application of that knowledge for the welfare of mankind, especially by the increase of food supply; yet no fact connected with nature was disregarded by him, and he laboured steadfastly to kindle in others that love of nature which inspired himself, and to set every one with whom he had to do, to use their own eyes and faculties, in observing and recording facts of natural history.

Fish culture was henceforward his chief pursuit, and his life became one of incessant activity, bodily and mental. As the knowledge of fish-hatching spread, many sought his aid in fitting up the apparatus in different parts of the country, and it became necessary to provide ova for the multiplying nurseries. Winter is the spamning time for trout, and in January and February of each year he worked hard in collecting trout ova in different rivers -no easy task in time of frost-the intervals of time being filled up with literary and other labour. He corresponded also with the directors of the French Government Establishment of Pisciculture at Huningue, whence he received consignments of fish ova, principally of salmon, salmon trout, and Great Lake trout. As the eggs were collected or received, immediate provision was made for tleir nurture on artificial gravel beds with running water. Some were distributed through the country to those who were beginning fish culture, others were temporarily provided for at his own house. These are among his notes for one month :- 
'February 6, 1863.-Dhifted my eggs into a bath in my room.

' 7th. - Down to Chalfont Park, Gerrard's Cross, to Mr. Hibberts, and robbed trouts' nests of several thousand egg's. Brought eggs home and put them in the "Field" office. No eves yet in the eggs.'

' 9 th.-Eggs of first lot of Rhine salmon hatched out in my bath.'

'12th.-Down to Carshalton with S. Gurney, Esq., M.P.; got about 3,000 trout ova. Mr. Gurney offers water for acclimatisation experiments.'

' 17th.-To Carshalton; spawned a hat-full of trout ova, white and red. 3,000 salmon trout and 2,000 Great Lake trout came from Huningue.

' 18th.-Took Great Lake trout to Zoological.'

'21st.-To St. Mary Cray to get ova for Mr. Hall of Farningham. With me went Bartlett and Pennell. Got between three and four thousand. Salmon ova arrived from Galway yesterday.'

' $23 r d$.-Busy with the fish all day. Received salmon from Allies; exchanged fish with Bartlett.

' 24 th.--Read paper at Zoological on fish-hatching; a great success.

' 25th. - At British Museum dissecting salmon with Günther; lunch with Gould; talk about ouzel.

' 26th.-3,000 Great Lake trout eggs, 1,500 Ombre Chevalier, and 2,000 salmon trout arrived; left them in box all night.'

' 28th.-2,500 Great Lake trout eggs arrived.'

'March 3.-With Mr. Youl by appointment, and examined the salmon ova he had packed in ice, which 
had been there forty-five days. Duke of Argyll called on me about grayling spawn; lots of people at "Field."

The intermediate days were much occupied with meeting numerous persons, including Professors Huxley and Flower, at the 'Field' office, explaining the fish-hatching apparatus, and enlisting their sympathy and aid.

Several letters on fish-hatching were also written to the 'Times,' attracting public attention.

He showed the fish-hatching apparatus successively at the Microscopical and the Royal Societies, and also at the Dog Show at Islington, where it excited great interest, and where he was first introduced to the Prince of Wales, who 'examined all I had to show him, and was most kind and gracious.'

'The crowd round the boxes,' he wrote, 'was thick, as I know from personal experience, and there were often so many good folks pressing to look at the fish, that I was in fear and dread that I should be speedily buried, fish and all, in the ruins of the entire edifice. The week at the Dog Show was great fun, and upon my word I do not know whether the young salmon and trout did not think themselves equally honoured as their master. Fish of the world are they, travelled fellows, distinguished foreigners, who have been naturalised in England, according to the proper forms and regulations; taken from their original home, the Rhine, the Lake of Geneva, or trout streams in the south of France, collected at Huningue under the fostering care of my good friend M. Coumes, the chief engineer of the Piscicultural Establishment; stuffed into moss in the form of eggs, shut up close in bottles, and packed tightly in boxes, they have travelled many a long mile both by rail 
and steamboats; hatched in the "Field" window in the middle of London, the "lions" of a soirée at the Royal Society, the subjects of a lecture at the Royal Institution, the theme of many a friendly argument both in print and viva $\hat{a}$ voce, these civilised and tame salmon will indeed have some fine yarns to tell the rude and wild salmon when they meet them again. They were insulted but once, and only once, when it was suggested they were only dog-fish after all, or they would never have been admitted into a Dog Show. Anyhow, these pretty silver-coated little creatures afforded pleasure and amusement to many thousands of people, who have certainly never seen a salmon alive before, and who looked upon a salmon as simply an article of housekeeping, and fit only to be cooked and eaten, a sort of aquatic leg of mutton or shoulder of lamb, instead of a fish full of life and activity.'

After considerable trouble, Frank Buckland arranged for fish-hatching boxes to be exhibited in the South Kensington Museum, and also at the Crystal Palace. In April he delivered a Friday evening lecture at the Royal Institution on fish culture. It was a novel experience to the grave members of the Royal Institution to laugh heartily at the racy humour with which the new practical science of fish culture was explained, but it was irresistible, while the earnestness with which the national importance of the subject was enforced was none the less impressive.

The substance of the lecture was expanded into a book published shortly afterwards, by which he endeavoured, not without success, to obtain also public attention.'

On Angust 11, 1863, he married Miss Hannah Papes,

' Fish-ITatching. Tinsley. 1863. 
having shortly before taken the house, now No. 37 Albany Street, Regent's Park, in which he continued to reside during his life; and where he accumulated a store of specimens of natural history and other curiosities, and gathered round him a succession of pets, monkeys and stranger animals, with whom he lived in close social intimacy and mutual affection; while fish-hatching, and, later on, fish-casting were actively carried on in the basement.

The household arrangements were unconventional, and his Journal occasionally records experiments in unusual food. 'B. called; cooked a viper for luncheon.' 'To Weybridge ; out fishing with $\mathrm{P}$. and W.; cooked perch and frog on the shore.' 'Had some elephant-trunk soup.' The trunk itself was boiled for days, if not weeks, without being sensibly mollified. A plentiful supply of roast giraffe appeared when the giraffe-house at the Gardens was burned; the meat was white and tasted like veal. Other deceased animals from the Gardens were occasionally experimented upon.

His home in Albany Street became the rendezvous not only of all who loved-practical natural history, or sought information on any subject connected with his favourite pursuits, but also of many outlandish folk.

' July 6.-The New Zealanders came to lunch with me. Afterwards went to the Zoological Gardens, and over the First Life Guards' stables. Altogether great fun.'

They showed intense fear at the sight of the elephant, but were delighted to see the zebra, who, they said, had tattooed his face, and the chief offered to tattoo their host's face in return for his kindness, whispering in broken 
English, 'You good to me, me moco (tattoo) your face; me you tattoo beautiful as Rangativa.'

Among his numerous pets at this time, one of the most original was a 'Laughing Jackass,' of whose habits and behaviour he wrote this amusing description:- 1

' It is very necessary for those who wish to gain knowledge of natural objects to ascertain the local names by which they are called, in the places where the search fcr them is made. Thus a naturalist, desirous to obtain a specimen of a bird peculiar to Australia, would exceedingly puzzle his friend if he wrote to tell him to send home a "Dacelo Gicas;" but if, on the contrary, his friend were told to send a "Laughing Jackass," he would probably be able to execute the commission. Australia, like China, is a very queer place, and there are some very queer animals in it. Among the birds of Australia, I know none more extraordinary than the "Laughing Jackass." He is a true kingfisher alike in his personal appearance, his structure, and his habits. One's idea, however, of a kingfisher is generally associated with a water-loving bird; but this Australian kingfisher is not a water-bird, but a land-bird, and preys not upon fish, but rather upon grubs, worms, snakes, frogs, mice, \&c.; he is, in fact, a scavenger in the true sense of the word, and if any creature ought to be protected more than another it is that which performs the duty of a scavenger.

'It has been stated that the only things which acclimatise themselves, without pain or trouble being taken in the matter by human beings, have been rats and blue-bottle flies-a fact which may possibly excite a smile; but when

\section{The Queen, June 186t.}


we come to consider the matter philosophically, rats and blue-bottle flies are, in reality, among the most useful of created things to the human race. True it is, indeed, that we cannot eat them; but everything in this world was not made to be eaten, and these despised creatures really do great service to us by getting rid of decajing substances, which would otherwise breed fever. Now, the "Laughing Jackass" is of the greatest service to our friends in Australia in his humble capacity of scavenger. How thankful would every person in danger from the bite of a venomous snake be, to see a "Laughing Jackass" suddenly descend from his perch, and seize upon and devour the poisonous reptile on which, in another instant, he might lave placed his foot, and have received a lethal wound.

"The "Laughing Jackass," therefore, of Australia, is one of the most useful birds-I might almost say " protecting" birds - not only to the person but also to the property of the sheep farmer. This "gogera," as it is called by the blacks, is, withal, a merry, joyous fellow; he is not a sulky-looking creature, like the vulture of ill omen, but he shows the delight with which he goes about the work nature has appointed for him to perform by laughing most heartily; not a faint, languid expression of pleasure, but a downright hearty laugh. A lot of them, we learn from Dr. Bennett, may be seen high up in a eucalyptus or gum tree; and when the traveller attempts to drive them off, instead of flying away, they will commence a hearty laugh, one joining in the chorus after another till the whole forest resounds with their merry music. Asop recurds the fact of an old lady, who, in order to make her maids get up early in the morning, took special care of a 
fine specimen of a "bright chanticleer," whose special duty it was to "proclaim the morn" to the sleepy servant maids. Should any of my readers wish to make their servants get up in proper time, let them at once purchase a " Laughing Jackass," and if this fellow by his cachinnations does not wake the whole household, he will have lost the good character he possessed when at home in Australia. I once heard that a visitor to a country farm declared he could get no sleep at night, inasmuch as the geese kept up a continual dialogue throughout the hours of darkness; when morning arrived the cocks and hens began their chatter; at last they went out with the geese to feed, and the unfortunate country risitor thought he would have some repose. Vain hope indeed, for the farm men came and lillled a pig under the window, thus rousing him up entirely for the rest of the day. If the owner of the farm had happened to have been the possessor of a "Laughing Jackass," I warrant he would have made as much noise, as did the poor pig when in the hands of the farm men.

"For the last few days I have had a "Laughing Jackass" in my possession —as fine a jackass as could be found within a hundred miles of St. Paul's. In fact, I had only one fault to find with him, and that was that he would never laugh. The cause of this defect in his education possibly may have been, that I never gave him anything to laugh about; this, however, was not $m y$ fault, for I gave him plenty of good and wholesome food in the shape of raw meat, \&c., which he took with a dignity becoming this most distinguished of strangers. Wishing, moreover, to try his destructive powers, I showed him one day a monse; in a moment all his feathers bristled up, and he appeared 
to be (like an enraged tom-cat) twice his natural size. I held the mouse to his cage, and in an instant he seized the animal with his tremendous beak, and gulped him down with apparently the greatest satisfaction. He then began a slight titter, which I trusted lie would increase gradually to a laugh, but I suppose he thought it an occasion hardly worth laughing about, so he shut up his feathers again, and composed himself to sleep. In this attitude I fancied I detected a sly expression about his eye, as much as to say, "I know you want me to laugh; I can laugh if I like, but I will not laugh." My bird was about the size of a large magpie, very like an English kingfisher in general shape; though his colour was brown, still he was a very pretty bird-so beautiful, indeed, was he that a lady borrowed him, for a day or so, to exhibit him at a bazaar in the Hanover-square Rooms. Here, I understand, he was much admired by the fair visitors; though, from all I hear, he did not appreciate the compliment as much as he ought. In due time he was brought back home. I gave him his breakfast, and put him out in the sun, which he much enjoyed after his sojourn in a hot, crowded room. I turned my back for a moment, and on looking round again was perfectly horrified at what I saw. Alas! alas! the jackass had found a bar of the cage, which had been broken at the bazaar, had tested it with his beak, and finding that it yielded, had pulled it on one side and flown away. Delighted with his cleverness, and, possibly, also rejoicing at the discomfiture of his owner, away be flew into the Regent's Park. One parting farewell only he gave me; the rascal actually stopped in his flight, and for the first and last time I heard his hearty laugh. The poor bird had 
at last found out something to laugh about, namely, that he had made his escape most cleverly, and that, though he had been denominated a jackass, his actions and the clever manner in which he got out of the cage proved most effectually that he was really no jackass at all.

"Everyone who has read that capital story, "Lost Sir Massingberd," will know what tremendous mystery was excited by the sudden disappearance of this cruel, hardhearted country squire, whose body was ultimately found (as everyone knows) in the hollow of an old tree. When my "Laughing Jackass" flew away, I was in a state of despair, and as the angler, when he has lost a fish, invariably stares straight into the water as though that would recover the fish, so after my "Laughing Jackass" flew away I frequently found myself staring vacantly in the air, in hopes I might see something of the lost pet. I have recovered him, and in this wise:- He escaped from his cage on Sunday morning, and on Monday night I was greeted with the agreeable news that "the Laughing Jackass had come back." It appears that a gentleman living in Stanhope Street, Hampstead Road, had, on going into his bedroom, the same day that the bird was lost, found him perched at the foot of his bed fast asleep, looking as merry and as comfortable as possible. Thinking that this was a strange bird, which had escaped from the 7oological Gardens, he went the next day to the gardens; Mr. Bartlett knew it must be my bird, and accordingly the bird was sent to me. On his arrival his left wing was immediately cut with a pair of scissors to prevent further accidents. Immediately the operation was performed he attempted to fly away, and, finding that his wing would 
not act, he lost his temper, and turning round pecked most furiously at his cut wing-in fact, he was so very angry at finding that his wing would not act properly, that he hopped round and round the table, and uttered sounds the very reverse of laughing. He was then put in a cage, and remained there all night, attempting to clean his feathers, which were as black as though he had come down a chimney. He was let out in the morning, and perceiving a pan of cold water, immediately plunged into it; he then went out in the sun, and spreading his feathers soon got dry. He remained perfectly sulky the whole of that day, but, towards evening, some cats came to pay him a visit; five regular vagabond London cats were these-black, white, tabby, and tortoiseshell. They all assembled round his cage, evidently thinking they had got hold of something good to eat; but the "Laughing Jackass," putting up his crest, and making himself look twice his size, fought them all in a most plucky manner, or, as my boy reports, "he regularly tackled all the lot of cats," who speedily beat an ignominious retreat, every now and then looking round, evidently angry at not getting a meal.

"The "Laughing Jackass," with his wing cut, now goes about the house. The other morning the big Turkish wolf dog, Arslan, was coming up the stairs at a gallop, when, suddenly, he came upon the "Laughing Jackass" sitting on the top step. The bird snapped his bill and ruffled his feathers. This was too much for the nerres of the big dog, who, giving a growl and an angry lash of his tail, ran down faster than he came up. Wishing to test the real powers of the bird's beak, I turned a frog loose before lim. The moment he saw the poor frog, he made 
up his mind it was good for food, and pursued it across the room, hopping very much with the peculiar high action of a street sparrow. The frog knew the bird was an enemy, for he also hopped away as fast as he could go, but the jackass was too quick for him. He caught him with his big bill, and made a motion as though he was going to swallow him forthwith, but, changing his mind, suddenly he hit the frog a most tremendous blow on the floor, and, in a minute or two, repeated the blow, knocking the frog about, as one sees Punch knock about the constable with his wooden staff. This was most interesting to observe, inasmuch as it proves the way in which this bird, in his native country, is enabled to kill a venomous snake without its being able to bite or kill him, for, being so shaken and knocked about, the snake has not time to turn round and bite. I have observed a somewhat similar thing in a young cuckoo. A piece of meat was given to the little creature; it immediately whacked the meat against the perch of the cage sereral times consecutively, evidently denoting the creature's habits of killing, in a natural wild state, caterpillars, which are very "hard lived" creatures, before it swallows them. I have also given the "Jackass" a dead muuse, and it is astonishing to see how quickly he snapped him up. It has been observed that, when live white mice are given to the animals at the Zoological Gardens, the visitors exclaim, how cruel to sacrifice the "dear little white mice;" but when the common brown mouse is given it would appeal, from the remarks made, that there is no cruelty in the matter. It is, however, in fact just as bad to give a brown mouse for food to an animal, as it is to give a white mouse. It would, moreover, seem to be the 
fact, that in some minds the brown mouse is supposed to be simply a "mechanical mouse," which is wound up by a hole in its side, and goes by springs under its skin; for I once heard a nurse say, that she would give a little live white mouse to a child that was ill, because the "nasty common brown mice would run round two or three times upon a plate and then go down; but the little white mice would run round the plate ever so many times, and never go down."

'A friend, who has been in Australia, has examined my bird; he knows him well, and has often seen him in his native wilds. He tells me that the bird has a custom of laughing in an aggravating manner when a misfortune happens to travellers. Thus, when a waggon loaded with goods breaks down in some desolate region on a long march, and the owner is in a great state of mind to get it right again, a "Laughing Jackass" is sure to appear at the top of a neighbouring tree, and laugh in the most aggravating manner at the miserable condition of the traveller, till the woods resound with his merry " $\mathrm{Ha}$, ha, ha! He, he, he! Oh, oh, ho!" Many of us, I think, might take a lesson from the poor "Laughing Jackass," for surely there is no sweeter music than a hearty laugh, be it from man, woman, or bird.'

In 1862 and 1863 several live porpoises were brought to the Zoological Gardens, but having been injured in capture, lived only a few days, although nursed and doctored with tenderest care by Frank Buckland. He took them in his arms and administered sal volatile or brandy-and-water, with temporary relief, applied caustic to their wounds, causing lively emotion, tempted their appetites with 
varieties of fish, or fed the young ones with a baby's feeding-bottle.

The third porpoise lived for a short time in the sturgeon's pond, and having been described by Frank Buckland in the 'Times,' was honoured with an elegy in 'Punch' by Thackeray, which should not here be omitted.

\section{ELEGY ON THE PORPUISE.}

BI the StURgen.

DEAD is he? yes, and wasn't I glad when they carried away his corpus,

A great black oily wallowing, walloping, plunging, ponderous porpus. What call had Mr. Frank Buckland, which I don't deny his kindness, To take and shore into my basin a porpoise troubled with blindness? I think it was like his impudence, and p'raps a little beyond, To poke a blundering brute like that in a gentle fish's private pond. Did he know as I am the king of fish, and am written down in histories

As meat for his master, that is to say, for Victoria the Queen, his mistress?

And, if right was done, I shouldn't be here, but be sent in a water parcel

To swim about in a marble tank in the gardings of Windsor Castle. And them as forgets the laws of the land, which is made to rule and control, Aud keeps a royal fish to themselves, may find themselves in a hole. Is a king like me, I humbly askr, to be put in a trumpery puddle, For fellows to walk about and spy, and talk zoological muddle? And swells to come for a Sunday lounge, with French, Italians, and Germans,

Which would better become to stop at home and think of the morning's sermons.

And then of a Nonday, to be used in a more obnoxious manner, Stared at by rags and tags and bobtails, that all come in for a tanner. $A$ nd ine, the king of fish, indeed, which it's treating china like delf, Mr. Kingfisher Buckland, Sir, I think, you might be ashamed of yourself. 
And then I can't be left alone, but you come and stick in a big, Blind, blustering, snorty, oily beast, which is only an old sea pig.

I'm heartily glad he's dead, the pig; I was pleased to my very marrow,

To see the keeper wheel him away in that dirty old garding barrow. And thought it was not flattering, last Sunday as ever were, To hear the swells as had read the 'Times' come rushing up for a stare, And crying, ' Bother the Sturgeon, it's the Porpus I want to see,' And going away in a state of huff, because there was only me. It was pleasant (and kings have right divine to feel a little malicious) To see 'em sent to behold his cops in the barrow behind the fishhouse.

So when Mr. Buckland next obtains a porpoise as wants a surgeon, Perhaps he won't insert that pig beside of a royal sturgeon. I've heard the tench is a cunning fish, and effects a perfect cure Of other fish put into his pond, which he's welcome to do, I'm sure: But don't bring sick porpoises up to me, I'm kin to the old sea deril, And though a king, I'm not inclined to be touching fish for the evil. Besides, a Porpus isn't a fish, but a highly-developed man; Improved, of course, with a tail and fins, on the famous Westiges plan. The Phocænor Rondoletii, though his scent in sultry weather Was not like Rondoletia nor Frangipanni neither; But that is neither here nor there, and as I previously snid, From the bottom of both my heart and pond, I'm glad the porpoise is dead.

Royal Zoological Gardens.

The Sturgeon.

At this time the natural history columns of the 'Field,' of which department he had become editor, and later those of 'Land and Water,' teemed with curious correspondence and discussions. These columns were his lifelong delight; no crabbed refusal, no supercilious sneer, ever disheartened those who sought knowledge in them, or tried to add to its stores. Everybody was heartily welcome to contribute, so that they were in earnest and loved nature, and every contributor seemed to find a ü. friend in the genial and kindly editor. 
The Acclimatisation Society continued to engage much time and interest. A visit to the Treasurer of the Society, Mr. Bush, who took charge of the animals on their arrival in this country, he thus described in August 1863:-1

'It was only the other day that I found myself sitting on the top of a carrier's light cart, jolting through the purlieus of Whitechapel, the "conducteur" of a valuable cargo; for behind me were two large crates, the one containing two "native companions," the other an emeu, sent to the Society from the Acclimatisation Society of Brisbane. The poor birds, though kindly treated on board ship, were in a terrible state of alarm as we jolted over the stones, and uttered plaintive cries of distress and uneasiness; and when, arrived at their journey's end, Mr. Bush and I unpacked them, they seemed shy of us, and retreated into a corner like naughty children. Now, how different are these poor birds! No sooner did I come out of the door with Mr. Bush, than the "native companions" (the Australian name of a large and handsome species of crane) came rushing up with outspread wings to the iron railings; the emen, who was feeding near the Chinese sheep at a distance, came hasting up with that peculiar swift but onesided run which is so very remarkable. The birds patiently waited their master, and, when he approached, the cranes began a sort of "niggers around" dance, and stretching up their long necks with a cry of pleasure, reminded one of the picture in "Assop's Fables" of the cranes asking Jupiter for a king. They seemed to know where Mr. Bush's pockets were, and were not disappointed. One of them 
has a game leg, and it was most amusing to see him hobbling about lest his companion should get too much, for even in animals, as, I regret to say, in our own species, the moment an individual, by his own exertions, obtains any success, others immediately try to wrest it from him. When the native companions had received their rations, Mr. Bush went close up to them. They did not attempt to run away, but, on the contrary, bent down their heads towards the ground, and made the most absurd bow, amounting to a curtesy, as graceful as any young lady would give at her first drawing-room. It was, moreover, curious to remark, how impatient these birds are (as, indeed, are all animals) of the human touch. After they had been caressed by the master, they ruffled up all their feathers with a shudder, and then arranged them with their long bills, though they were apparently in perfect order before. I observe something like this among ourselves. People who have their hair cut, generally have it neatly brushed by the hairdresser, yet nine people out of ten will borrow the hairbrush and arrange it for themselves, even though, to outward appearance, it requires no arrangement whatever. I have asked a hairdresser if he has observed this fact in his shop, and he says that it is so, but he cannot account for it, neither can I. I should like to know if ladies give the finishing touch with their own brushes, when the court hairdresser acknowledges their coiffure quite perfect. While the native companions were eating, the emeu was in a great state of mind. He stretched out his long neck, and cried with a peculiar piteous cry, very like that of the seagull, which we hear in stormy weather at sea. He pecked at everything 
offered, but, somehow or another, seemed to know if it was good to ent or not; and here let me observe, that bircls, eren thongh they have horny bills, have the sense of touch or taste highly developed, for I have often seen poultry reject what was not good for them to eat; and, again, I never saw a cock or hen take a bad shot at a grain of wheat or corn which was good to eat. In the same way, the emeu pecked at everything proffered, but rejected all but that which was fit for food; he tasted a cigar end, but swallowed a lump of barley-meal. This bird has a most tremendous appetite, and eats as much grass as a sheep. When he is eating his attitude is remarkable. He squats down, with his long legs parallel to and on the ground, and pecks away at the grass, tearing it up somewhat after the fashion of a goose. When he wishes to advance, he does not get up on his feet, but moves his legs forward like a man walking on his knees. I think that this must be his proper attitude when feeding in the bush, for, if erect, his tall stature would call the attention of the native " black men," wbo from afar would quickly have his head off, with a stroke of that terrible weapon in trained hands, the boomerang. In a crouching attitude he has a much greater chance of escaping observation and saving his life. A friend has asked me to examine an emeu's nest which he has brought with him from Australia. I do not expect to see much of a nest, for it is curious that these great running birds, who never fly (for they have hardly any wings), seem very careless about their nests; whereas birds that fly in the air, and are bad runners, have a much more complicated and highly finished nest. 'The eggrs of the emen are of a beautiful green colour, and she makes 
her nest in the bush. May not the green colour have somewhat to do with the preservation of the egys from depredators-both men and animals? The ostrich places her egg's in the sand; they are not green, but of a somewhat sand-like colour. It would be a curious subject to ascertain how far the colour of eggs laid by the birds in open nests on the ground coincides with the soil and vegetation on which they are placed. The emeu has been known to lay eggs in England. Could we but once get them as common inmates of gentlemen's parks and ornamental grounds, who would say that the Acclimatisation Society had not done some good? They would surely be great pets with the ladies; and if the gentlemen must have some sport out of them let them course them; it would, however, require a good dog, barring a greyhound, to catch them; and when the dogs did come up alongside them, they would still have to keep clear of the kicks, which the bird can give, if he pleases, with a vengeance. In the yard were the Honduras turkeys, the guan, the dusky ducks, the black-bone fowls, the rooks, the bronze-winged pigeons, \&c., \&c. These creatures knew the master's footfall, wero all ready to receive him, and wherever he went they dogged his footsteps, as though they knew that he is their true friend and protector. But of all interesting little birds commend me to the trumpeter birds. These little creatures hail from South America. They are about as big as a Guinea fowl, and instead of the cry of "come back," "come back," utter a peculial musical note, whence they derive their name of "trumpeter birds." These birds are more than tame, they are as domesticated as dogs, and seem unhappy if not in the society of their master 
and mistress. They sit outside the hall door, and, when they have the chance, come trumpeting in along the hall as though they knew they were trespassing, till they arrive at the dining-room, where they will introduce themselves, and perch down with a lack of shyness which would be invaluable to many of us. In their native country they are said to be used to help the shepherd drive his flock, and the story holds good, for Mr. Bartlett tells me that when he wants to catch a bird out of the aviary at the Zoological Gardens, where the trumpeter is, the bird will see what he wants, and belp to drive and cut off the individual bird that is to be captured.

"The latest importation we visited was the wombat from Australia. Mrs. Bush said he was like a "big rat"; we agreed he rather was like "a little bear," but none of us could see much of him, as he was still in his tin-lined case, and as disagreeable as possible. We hauled him up to the light to look at his formidable teeth and terrible scratching claws, and were only glad to let him go again, when he scuttled to the back of his box, and grunted defiance. Never mind, Mr. Wombat; if Mr. and Mrs. Bush don't tame you, and that very shortly, it will be indeed wonderful, and you will be an ungrateful wombat. In a few days, I hupe, you will have learnt English manners under their superintendence, and then, if you behave yourself, I will introduce you to my readers.'

In 1864, Frank Buckland visited Paris, and personally discussed pisciculture and acclimatisation with M. Coste and other French savants interested in those subjects.

Both these interests were combined, in the endeavour to introduce trout and salmon into our Australian colonies, 
which he this year commenced in conjunction with Mr. Youl. The success of this experiment was thus described in the official report of Mr. Ffennell, the first Inspector of Fisheries for England and Wales:-

'The most interesting event in the experiments that have been made in artificial propagation, perhaps, is that so successfully carried out in transmitting salmon and trout ova to Australia. The first attempt failed. The eggs were sent out placed in water-troughs in the usual way; but, although ice was employed, it was found that the water could not be kept in a state to enable the tiny creatures to live through the voyage, although they were hatched. An experiment was then tried by embedding some ova in ice, at the Wenham Lake Company's Stores in London, under the direction of Mr. Frank Buckland. This scientific conception resulted in a most valuable discovery; it was found that after incubation had been thus suspended for over one hundred days, the vitality of the ova had not been destroyed, and when placed in running water, under the influence of a natural atmosphere, that the fish came into the world strong and healthy. A vessel was chartered and made ready for the next spawning season, a good supply of ice laid in, and a quantity of ova obtained and despatched; it arrived safely, and, being placed in the waters of the country for which it was destined, under suitable arrangements, in due time produced its welcome offspring; they have arrived at the smolt state, and have been enlarged for their journey to the sea; their return as grilse will be anxiously watched, and may be hopefully looked for. Those who have carried out this very important under- 
taking so far, deserve the highest praise for their enterprising zeal, perseverance, and scientific skill in this effort to introduce salmon into the waters of a far-off country, where they were before unknown; and with the name of Mrr. Frank Buckland, before mentioned, who superintended the scientific department, the names of Mr. Youl and Mr. Wilson, of the Australian Acclimatisation Society, should be recorded as taking a foremost part, undaunted by every difficulty that arose, in the accomplishment of so interesting and important an object.'

In the same year, Frank Buckland read a paper before the Zoological Society on hybrids of fish and development of their ova, giving the results of his experiments on crossing the breed of salmon and trout. The whitebait fishery was also examined, and papers were written identifying whitebait with the young of the herring and sprat, associated with other young fish; and, amid more serious labours, he examined and exposed 'the humbug of spiritrapping,' which was then in fashion.

In 1864, Mr. Ashworth, one of the chief promoters of pisciculture in Ireland and the owner of valuable salmon fisheries in Galway, invited Frank Buckland to come to Ireland, and tell him what had become of all the salmon fry he had hatched, and turned out in a rearing pond, in order to stock Lough Mask with salmon. The mystery was soon solved; the pond was found swarming with Dytiscus, a carnivorous water-beetle. One of these creatures was caught and put into a bottle with two little salmon, which it killed and ate up before Mr. Ashwortb's eyes, and then suffered the penalty of its misdeeds. • 
Frank Buckland's first sight of salmon in the Irish rivers awoke all his enthusiasm. ${ }^{1}$

'We came into Galway at dusk, tired, hungry, and dustcovered, but greatly pleased at a prospect of a little hard work out of doors. Early-bird fashion, I was up pretty soon to have a look about and a comfortable bath. I walked up from the fishing-house to the weir, and just above the bridge perceived a number of dark-looking objects lying motionless in the glass-clear, ever-flowing water. The morning sun was shining bright, and I was fearful my shadow would fall on the objects, whatever they might be; so I dropped instantly on my hands and knees, and bending forward craned my neck at them, feeling a sensation, I should imagine, similar to that experienced by a pointer dog, when making a discovery of a covey of partridges on the 1st of September. Can those dark-looking bodies, then, be salmon? Oh! you shining lovely creatures! At last, then, I see you free and at liberty in your native element. Mysterious water fairies, whence come ye? Whither are ye going? Why do ye hide your lustrous and beautiful figures in the unseen and unknown carerns of the deep blue sea? Why do ye shun the eye of mortal man? Hitherto I have seen only your lifeless, battered, and disfigured carcases mummied in ice and lying in marble state on fishmongers' slabs. Who could beliere that in life you are so wondrously beautiful, so mysterious, so incomprehensible?

'The Galway salmon-ladder is a fine specimen of its kind; it is constructed of solid slabs of stone admirably placed. Letting myself down from the platform abore, 1

- Curiosities of Natural History, Third Scrics, vol. i., p. 124. 
observed that the water from the lake came through the first slot or opening in a solid, quiet-looking, board-like mass; but once in the steps of the ladder, it bubbled and boiled famously like a young Niagara. Being in an experimental turn of mind, I bethought me that I would, for a moment, just try and see what sort of sensation the salmon experienced when making their headway througb this cataract, and at the same time get a pleasant morning bath. Oh! that I had scales and fins for five minutes, thought I; never mind, I must do without them. I then stepped into the ladder, but as quickly scrambled head orer heels out again, for the water had a strong will of its own, and was terribly powerful, tripping up one's feet in an instant. But it will never do to give it up; so I made a cautious descent into the ladder, and, placing my feet against the steps below me, imagined myself a salmon, congratulated myself on narrow escapes from the nets and. the crevices below, and thought how very desirable it would be to get up to autumn quarters in Lough Corrib above. But all I could think or do, I could not advance one single inch. If I moved, in an instant the water knocked me about like a wood-chip in a street-gutter after a thunderstorm. So I chose the corner of the ladder where the water bubbled round, and sat there in state, wishing and trusting that some salmon would take it into his head to ascend the ladder while I was there. We should hob-nob very well together, thought I; and we will smoko the pipe of peace together. Presently I heard a voice behind me, "Bedad, your honour, you're the finest fish $I$ ever see in this ladder this long time; and, by the powers, if I had got a gaff in my hand, I'd just 
strike it into your scales and see how you would like it." I looked up, and there.was one of the water bailiffs, who, watching me from afar off, could not imagine what curious white-skinned creature had got into the ladder and was floundering about in it.'

In October 1864 he visited the Bishop of Oxford at Lavington.

'October 5.- Started at 12.5 to the Bishop of Oxford's; arrived there about 3 P.M. Out for a walk with the Bishop and Archdeacon Randall; very pleasant conversation together. Large party at dinner. The Bishop very agreeable. Met Captain Henry, with his wife and daughters, also Ernest and Basil Wilberforce.

' 6 th.-Pottering about, and showed them the oysters. Out jack-fishing in the pond; missed three beauties. The pony ran away with us twice, causing to self fear and trepidation. Sat next the Bishop at dinner, and kept the ball alive.

' 7 th.-Hunted rabbits with the Bishop's sons; then in the run-away pony-carriage to the station and up to London.'

The Bishop's note is, 'Lavington. We hare had Frank Buckland down for a few days, and very good fun he was; full of his natural history, and so simple and unaffected as to make him really very charming indeed. He has put them on trying to make the trout-fishing better; so we are moving the sheep-wash, which, he sajs, poisons the fish, to the bottom of Grafham village, and there are to be regular spawning beds kept.'

To preserve and render popularly visible the results of his investigations into fish-breeding, he now began to cast 
the roe of fish, and the forms of fish at different stages of growth. For purely scientific purposes, it may be preferable to preserve specimens in spirits, but such specimens are of little value for popular exhibition.

Frank Buckland's aim was to render the facts of pisciculture plain to ereryone, and for this purpose a coloured cast appeared to him best to convey to the eye the facts he wished to enforce. This was the beginning of that series of casts of fish, which remains at South Kensington a monument of his industry and scientific devotion.

'November 28, 1864.-All day in the kitchen casting fish; the eel and the salmon; made some awful failures, but did not knock anything to pieces.

'December 3.-Mr. Durham came to show me how to make casts of fish.'

In this year Frank Buckland extended his investigations to oyster culture; carefully examining the principal beds, and making experiments on the spatting or breeding of the oyster ; and read an elaborate report on this subject at the meeting of the British Association at Bath. A course of lectures was also given before the Society of Arts, and three lectures at the London Institution on the artificial breeding of fish and oyster culture; he lectured also at Woolwich, Bagsloot, Clapham, Weybridge, and at Liverpool, and also in Ireland. He also took part in the formation of a Company for the culture of oysters at Herne Bay, and gave evidence before the House of Commons on the subject. The Company, from which he afterwards withdrew, was not, from various causes, ultimately successful.

The artificial culture of the oyster had long been carried on in France, at Cancale and Arcachon, in a more elaborato 
manner than had hitherto been attempted in England; and the growing scarcity of oysters made it important to inquire into the causes of their failnre, and the best means of increasing their supply.

Heat and tranquillity were the conditions necessary for a good fall of 'spat,' as the oyster brood is called, and there had been successive cold and stormy seasons at the breeding time.

In the early summer, when the months have no ' $T$ ' in their names, and oysters are out of season, the lady oyster emits the grey 'spat,' which clouds the surrounding water and floats to the surface. Seen under the microscope the grey cloud is resolved into a multitude of sand-like grains, each a minute bivalve oyster, but furnished with a row of ciliæ or legs, with which the tiny creatare makes haste to swim away, in search of some hard substance, whether rock or shell, or artificial tile, to which it can adhere. Having steered their owner to some safe anchorage, the cilix are no longer required, and the young oyster remains fixed for life, until three or four years later the fatal dredge lifts him again to the surface, and he is carried off to market.

If, when the spat is emitted, the water is cold or storm?, the tiny oyster cloud sinks to the bottom and dies, while, in warm calm weather, it spreads far and wide over the rocks and shells, and forms a 'golden spat.'

Much, however, may be done in the way of culture by placing the oysters in favourable breeding beds, strewn with tiles, slates, old oyster shells, or other suitable 'culch ' for the spat to adhere to, and clearing the beds of the oysters' enemies, the whelk-tingle, which bores a hole through the orster 
shell with its sharp tongue, and the star-fish, or five-finger, which clasps the oyster round, and, insinuating its slender feelers between the shells, sucks out its life.

The position of the beds, too, and the food of the oyster must be studied. The brackish water of estuaries, as at Whitstable and Colchester, furnishes food; here are the best fattening beds, and to them are transferred the young oysters from the deep sea, where they develope thick shell and little meat; but, laid down in the fatting beds, they grow up thin-shelled and plump.

These, and other principles of oyster culture, Frank Buckland studied and worked out, by personal observation and familiar intercourse with the oyster dredgers; and then strove, by lectures and writing, to make them matters of common knowledge and interest to all classes of people.

With what energy he threw himself heart and soul into this work, and fish culture generally, his Diary shows. At the close of 1864, he visited Galway, to examine the salmon fisheries there, returning to England on New Year's Day, 1865. On January 5, he surveyed the Wye with the late Mr. Ffennell, then one of the Inspectors of Fisheries. On the 9 th, he was collecting trout eggs at Lord Dorchester's. On the 11th, at Lord Portsmouth's. On the 12th, he visited the Duke lof Marlborough, who always took a warm interest in his pursuits. On the $13 \mathrm{th}$, he returned to London and published in successive weeks papers on oyster culture in the 'Field.'

On January 27 he was at Aldermaston Park, Berks, the seat of his friend, Mr. Higford Burr, superintending the placing in his ponds of specimens of the Silurus 
glamis, a large fish introduced from Austria, an operation thus described :-

'In the month of January 1865 Sir Stephen Lakeman, who resides at Bucharest, in Wallachia, brought over to this country eleven specimens of silurus. They were about one foot long, and by any ordinary observer would have been taken for the ordinary burbolt. My friend Mr. Higford Burr, having prepared a pond to receive these valuable fish, I took them down immediately, and turned them out in the midst of a terrific snowstorm. On December 28, that is when the fish had been in the pond about one year, Mr. Burr let the water off the pond, and dragged it thoroughly with a net. He and I then waded about in the soft, almost dangerous, mud up to our waists, searching for the silurus with landing nets, but not one alive or dead could we discover. The squire and myself then met in the middle of the pond and shed tears, caused by the combined effect of intense cold, laughter, and grief. We trust that the silurus were buried for the winter deep in the mud, and we hope to have another hunt for them next summer.'

On January 30 and February 2, 1865, he was again in quest of eggs, wherewith to stock the fish-hatching boxes, now, owing to his enthusiastic advocacy, multiplying in many quarters; and after dining on the 14th at the Hunterian dinner, on the following day went to Exeter to survey an oyster-bed. On the 28th he lectured at Sheffield, on March 2 at Nottingham, while the weekly natural history column of the 'Field' still had a full share of his attention.

In March he went to Windsor several times, to examine the fish-ponds, and set up fish-hatching boxes for the 
Queen, who took interest in this, as in everything affecting the welfare of her people, and in the same month he was appointed Fish Culturist to Her Majesty.

The Prince of Wales, and other members of the Royal Family, showed a warm interest in his labours to increase the food supply, and in April 1865, the Prince consented to become president of the Acclimatisation Society, Bishop Wilberforce also joining the council. The Prince Christian consulted him on matters affecting the deer and othe: denizens of Windsor Forest, of which His Royal Highness was ranger.

In this year he gave evidence before the Royal Commission on sea fisheries, and also before parliamentary committees on the fishery of the Thames, and the oysterbeds of the river Roach, and advised the Home Office as to the pollution of rivers, one of the most serious obstacles to the improvement of river fisheries.

Other lectures were also given explaining and advocating fish and oyster culture, and practical natural history, at the Russell Institution, thrice at the London Institution, at Streatham and Islington, besides country lectures at Southampton, Canterbury, and Worcester.

In May 1865, Frank Buckland was appointed Scientific Referee to the South Kensington Museum, and gave there a course of lectures, and of class demonstrations. On receiving this appointment, he commenced at once transferring to the Museum his collection illustrative of fish and oyster culture. He had already shifted all his fish down to the Horticultural Gardens, about 16,500 young fish and eggs, and henceforth devoted much labour and time to the preparation of specimens for the cases, which should illus- 
trate his lectures, and inform the public on the subject he had at heart.

In the autumn a paper was read before the British Association at Birmingham on the progress of oyster culture. His Journal records a variety of social experiences: visits to the Duke of Northumberland, the Duke of Marlborough, Lord Dorchester, Lord Burleigh, and others; also 'to see the Chinese giant; dined with him. Dinnerparty to the giant.' 


\section{CHAPTER VIII. \\ 'LAND AND WATER': 1866.}

Is January 1866, the third series of 'Curiosities of Natural History' was published, and, having now parted company with the 'Field,' Frank Buckland, in association with some friends, started 'Land and Water,' as an independent channel for diffusing knowledge of practical natural history, and fish and oyster culture. This paper soon attained a considerable circulation, due mainly to the interest his articles excited.

The organisation of the paper was a work of much labour and anxiety. The editing of the department of Practical Natural History was indeed a labour of love, but a very engrossing one.

"January 25.-All day at "Land and Water" office, getting ready the proofs.

"26th.-All day at "Land and Water."

' 27 th.-Worked at articles. "Land and Water" born at tro in the morning.'

'Let none,' he wrote in the first number, 'think himself unable to advance the great cause of practical natural history. Thousands of Englishmen and Englishwomen have knowledge and experience, acquired by their own actual observation of useful facts relating to animated beings, be they beasts, birds, insects, reptiles, fishes or 
plants. Friendly controversy and argument is invited on all questions of practical natural history, and although the Odium Salmonicum not unfrequently assumes more virulence than even the Odium T'heologicum of the good old days of faggot and stake, no writer need fear that his pet theory shall be ruthlessly set on fire, or that his arguments shall be decapitated, without a fair and patient hearing.'

His contributions to 'Land and Water' took the place of the correspondence of other men. "Write to "Land and Water" he used to say when questioned on any subject, 'I will answer you there.'

The incidents of his life were here narrated, the facts and observations he was ever accumulating were here recorded. Many of these papers have been recast and republished; others, hereafter extracted, may show the variety of subjects with which he dealt, and give a more vivid reflection of the writer's intellect and character.

These are examples from early numbers:-

'While lecturing lately at Worcester, a friend said to me, "Buckland, it is a very curious thing, but the salmon in the Seame always jump at the weir, at eleven o'clock on Sunday morning." I said it was a very singular thing, but he assured me that it was so. I shortly after met another friend, and I asked him also as to the time when the salmon jump most at the weir" and his reply was, "At eleven o'clock on Sunday morning, when they hear the church bells ring; it is the church bells that make them jump." I could not at the time make head or tail of this story, but I have since solved the difficulty. It is not the church bells that make them jump; but it so happens that 
on Sunday morning, the mills being shut lown, the water comes down over the weirs in greater abundance than on any other day of the week; the salmon find this out, and, like wise fish, make the best of their time in endeavouring to get over the weir.'

"The snails sent me have been carefully fattened on lettuce leaves, and I have eaten them. I fully agree with the gardener that they are "better nor a winkle." We send up large numbers of the common edible whelk from our oyster fishery at Herne Bay to the London market, and I have frequently tasted them on the London stalls, and I rather like them. The land snails are not quite so guod as whelks, but perhaps I made a mistake in preparing them; for my cook fled from the kitchen in dismay when told to cook the snails for dinner, and I was obliged to boil them myself.'

'Of fossil oysters, sent me from Chislehurst, there are altogether ten specimens, and I have no hesitation in pronouncing them to be natives of the first class. I showed them to an oyster merchant, who pronounced them to be worth (if not unfortunately fossil) about sixty shillings per bushel. The series is most instructive; we have two beautiful little specimens of thorough-bred "brood" from one to one and a lialf inches in diameter; for a similar sample the present market price is from a guinea to twenty-five shillings per wash. Then we have three specimens the size of marketable oysters; once plump, handsome, aristocratic-looking natives, now as solid as marble itself. Then we hare three specimens of oysters, which in the present stage would be considered too large for the London market, and would be thrown back on the bed to spawn. 
I have a "rough Whitstable" which exactly matches one of these fossil oysters, both in size and appearance-one might take them for twius. Lastly, we have specimens of the "culch" 1 of the period. On one shell there are eight spats, on another fifteen; another is a bouqnet or family party of seven. Oh, happy, happy days when there was a good crop of oysters every year, instead of, as norv, once in every five or six years!

'Now, what deductions are we to make from these fossil oysters? Chislehurst is situated about eight miles (as the crow flies) from Erith, which is the nearest point on the Thames - and at Erith the water is fresh and quite unsuited for oysters. These creatures must therefore have lived in times long anterior to onr own, when neither Anciènt Briton, Gaul, Saxon, Roman or Norman had yet placed a foot upon our soil, when the "London Clay" was deposited by the vast river which then drained lands now gone from human sight; and, possibly, at the time when logs of date and cocoa-nut and palm trees, perforated by sea-Tworms, were washed np upon the shores of the Isle of Sheppey, indicating an arrangement of continent and a drift of marine currents, differing widely from those now existing.

'These oysters probably lived in a pre-Adamic Whitstable in some ancient estuary, the situation of which is now faintly ontlined by the course of the river Cray ; there they lived a happy life, with no fear of dredges, cleaning harrows, or cultacks (instruments used in separating oysters grown too thickly together), till one day there came a heavy gale of wind at a high spring-tide, carrying with

1 old oyster-shells laid down on the bed to catch the spat. 
it a marine sirocco of fine sand and mud; the storm fell upon the poor oysters; some of them opened their shells only to be filled with sand and become "clocks" (technical term for dead oyster's when the two shells remain joined at the hinge). Have we not evidence of this now before our eyes? Others, again, locked and bolted down their shells, thinking (like the people who ran into their cellars when Pompeii was destroyed) thus to escape the sand storm ; but it was of no use; the whole family of these unfortunate orsters was smothered in its bed, and, converted into fossils, ire now to be turned out into light. I will gladly place these ofsters in my museum.'

$\mathrm{He}$ only found time for literary work by the constant habit of writing while travelling on the railway; a large proportion of his articles were thus written, and those nost rapidly dashed off were often the most successful. He thus made time to lecture in January and February at Hereford, Brecon, Leeds, Halifax and Bradford, and later on at Norwich and Herne Bay. The Journal of two weeks may serve as $a_{0}$ further example of the activity of his life.

'January 8, 1866.--By the 11.45 train went to Hereford with Ponder. Lloyd met us at the station, and took us both over to Huntingdon Court.

"9th.-With Lloyd in carriage to Hereford. Put all my things out in Town Hall. Lectured in the Shire Hall on salmon and oysters. The Dean in the chair. Grve a stupid lesture; much too anxious to do well, and spoke very much too quickly.

'10th.-To Brecon; put things out for lecture, then tried for salmon in the brook by $\mathrm{D}$-'s house; got one 
fine hen, but could not get a cock for her anywhere, a very great pity. Lectured at Brecon; gave a splendid lecture, because I took my time.

' 11 th._Up very early; took pair-horse carriage to the farmhouse close to a tributary of the Usk; put in the net, the current took it away in a moment; missed two splendid fish. Then tried river near the ford; got two fine cock fisl, no hen. Then tried ford, and got one hen half spent, and another hen quite full. Back to Hereford by the 5.30 train.

' 12 th. - By 9.45 train to Ross; met 1.40 train; Ponder there; with him up to London.

"13th.-Man brought heading for "Land and Water." Meeting of Helne Bay Company. Took second lot of salmon eggs down to South Kensington. Thus ended a most agreeable week, most pleasantly spent, in which I hare given and received much instruction.'

'18th.-To church twice. Dick, the rat, stole away two five-pound notes from my drawers.

' 19th.-Finished packing up my things for Leeds, and away by the 12 train.'

' 20th.-Walked about all the morning, and got lots of information about oysters. Gave my lecture at the Philosophical Museum; I am thankful to say it was a great success. Horsfall and another cross-examined me after the lecture.

'21st.-Packed up my things, and away to Halifax. Much pressed for time ; but, nevertheless, got lecture ready, and also sent back my proofs to London for "Land and Water." Gave a capital lecture for two hours, and much complimented by the chairman. 
' 22nd.-Went on to Bradford; nobody at the lectureroom to receive me; much disappointed at this. Wrote more "Land and Water." At 8.30, gave the lecture pretty well I believe, but the exertion very great, my brain being yuite worn out.

' $23 i$. - Came home by 5.30 express. Glad enough to get home after the tremendous hard week, and thankful to God for my preservation of body and strength of mind to go through the matter.'

His experiences in collecting salmon ova at Brecon before his lecture are thus told :-

'There are many serious difficulties to be overcome before the ova, either of trout or salmon, can be obtained, and they are not, as some folks would seem to think, to be picked up as easily as one can get hens' eggs out of the nests in a farm-yard hen-roost. Salmon ova are, for obvious reasons, more difficult to obtain than trout ova. I will, therefore, now give some idea how I obtained my last batch; for, it must be recollected, before you can get the egrgs, you must catch the fish, and to do this requires both time and experience.

' On looking out of the window of the hotel at early morning, I was horrified to find the ground thickly covered with snow, which was still falling heavily; it was the day of the great snowstorm, that did so much injury to the telegraph wires all over the country. We shall not care so much for the snow, I thought to myself, but I fear the river will have swollen much in the night, and render it very difficult for us to manage the nets. I therefore at once went on to the bridge, and sure enough she-I like the idea so common in some places of calling the river she 
-was coming down in fine style. As I looked over the lower arch of the bridge, I saw the water rusling through the buttresses like a huge mass of solid window glass, such as we see sometimes at the manufactories, giving one the same sort of giddy feeling, that it is difficult to help experiencing, when the express runs at full speed by the narrow platform of an intermediate station. On going to, the upper side of the bridge, I peeped gentiy over, and my eyes were gladdened at seeing in the bed of the river a huge mass of stones and gravel, about as much as would fill three or four railway wheelbarrows, turned up in the middle of the river; this I knew at once to be a salmon's: nest. Presently came sailing down stream sideways, reminding me much of a cavalry horse going through the exercise of shoulders-in in the riding school, a fine old male salmon, evidently, with his wife, the founder of this subaqueous edifice. The old fellow's coat was as red as a fox, and his great beak projected from his lower jaw, rendering him indeed a formidable opponent to any other salmon. On seeing me watching him from the bridge, he suddenly halted, winked his cunning eye at me, and was off in a moment, doubtless to warn his amiable spouse that there was something wrong, and that she had better keep out of the way for a few hours. Just then a man came down to the side of the stream, with a huge bundle of sheepskins on his back, and a stick with a cowhorn on the end. He at once began to wash the sheepskins in the river, twisting them about with his cowhorn-stick, an instrument most admirably adapted for the purpose. "Experientia does it," I thought, but I must have a word with the old man. On going close to the skins, I found they 
were the skins of Welsh sheep, and that the tails were left on. I immediately fell in love with one of the tails, made a bargain for it, cut it off the skin, and it was hauled out of the water. It really was a splendid bushy tail, and I hoped to have it mounted as a specimen of the "local products" of the place, and a rival to the yak's tail in the South Kensington Museum. Alas ! vain are the hopes of man; my sheep's tail has disappeared; the servants at home know nothing about it; and I find, to my sorrow, that my big. Turkish wolf-dog, Ar'slan, like his master, fell in love with it, and has eaten it up, wool and all.

'My watel'-dress put on, the nets and cans, \&c. packed, we started in a carriage, with a pair of fast horses, for a brook, which we calculated would not be running so much water as the main river. Our theory was right; but still there was too much water to render netting anything but very hard work. A pair of salmon had been marked down the day before; so taking out the pole of the pole-net (reader, imagine an old-fashioned, bag-shaped night-cap, with a stick fastened on each side of it, and you have a pole-net), I attempted to cross the stream, at a spot below where the salmon were supposed to be, and, with great difficulty (on account of the huge stones and tremendons stream, about an inch over the waist), I got across, and then, sticking the iron-shod end of the pole into the bottom of the river, I got to the lower side of the pole, so as to resist the pressure with my shoulder, while one of the keepers held on to the pole on the other side of the bank. My friends and the keepers then went about eighty yards up the stream, and began to beat it down, and to throw a shower of stones into the rapid, form-colonred brook. 
Almost instantly I perceived coming down stream, with the rapidity of a partridge's flight as he tops a hedge, two huge bodies and two black fins at the surface of the water. "Look out," cried my friend above, "they are coming down." It was with difficulty that I could hold the empty net against the stream, but when the two great fish came rushing on, all steam up, with a double-barrelled bang, bang, against the net, the whole apparatus was nearly jerked out of my hands. The instant the fish were in the net, I tried to scramble across the brook to the other side, with the pole in my hand, so as to enclose the fish and catch them. A huge stone was in the way, and, being over-anxious, I stumbled, and the stream as nearly as possible had me down; then, to add to my difficulties, just at that moment something ran between my legs, and nearly upset me altogether. "Oh dear! Oh dear!" I cried, "one of the salmon is gone, but we have got the other, for I can feel it jerking in the net." We hauled it quickly on shore, and my eyes were gladdened by the sight of a splendid hen salmon as full of eggs as could be, but remonstrating terribly in her way at the rude manner in which we were interfering with her domestic arrangements. I took her gently by the wrist, the thin part of a salmon's tail, and then let her down into the net I use for keeping fish alive, and went to work to catch her husband. We marked him down under a bank, but, when we came to try for lim, he was gone, having crawled in, as it were, under the roots of an old pollard tree, from whence no amount of stirring with sticks or pelting with stones would make him budge an inch; so Sir Salmon beat us after all. We then ade three distinct pitches with the nets higher up the 
stream. We caught two more salmon, but none suited for our purpose. It was getting dark, and we were all very wet and cold; so we adjourned the meeting till the next day. I have heard it said that the salmon has a small brain, and is therefore a stupid thing; for my own part, I think that though his brain is small, he can use it well. An angler, not long since, was fishing a stream in Ireland, and he cast his fly in a manner which did not meet with the approbation of the keeper, who repeatedly found fault with him. "Well," said the gentleman, "what matter can it be to you? I have leave to fish, and I shall fish as I like, and I shall throw my line in the manner that pleases me best." "So you may, your lionour," said the keeper; "but you'll catch no fish. Bedad! Does your honour think the fish have got no sense?"

'Of all disagreeable sensations, nothing comes up to the delights of having to ride in an open carriage some five or six miles, on a bitter cold day in January, with one's wet clothes on; and if to this be added a ravenous appetite, and no commissariat forthcoming, the pleasures of salmon-egg collecting can be fully realised.

'While lighting my pipe to rest a bit before further work, I said to my friend, "Did you ever hear the yarn of the Yorkshire gamekeeper and the pike? If not, here goes :-A keeper, strolling one day by the side of a stream, with his bull-terrier dog at his heels, came upon a man who wąs intently fishing for pike, one of which he had just landed, and which was then hopping about on the grass, not at all comfortable, in about as bad a humour as it is possible for even this surly fish to be. 'Hollo!' says the keeper, putting on as simple an appearance as he could, 
and eyeing the fish with a sort of curious gaze, 'would that fish bite?' 'Why, I don't know,' said the angler, diligently plying away; 'you can put your finger into his mouth and try him.' ' Oh, no,' says the keeper, drawing back; ' but I'll try my dog's tail if you don't mind.' 'Not at all, I shan't feel it,' was the reply. Accordingly the keeper, having caught his dog, put his tail in the pike's mouth. No sooner did the pike feel the tail than he took hold, fixing his sharp teeth deeply into it. The dog inmediately ran off at his hardest, singing 'pen and ink,' making his way home as fast as his leg's would carry him. At this the keeper laughed heartily; not so the angler, who sang out in his loudest voice, 'Oh, I say, Mr. Keeper, call back your dog.' 'Not I,' says the keeper, walking away; "you call back your pitie."

At Leeds, Halifax, and Bradford, Frank Buckland endeavoured by his lectures to impress on manufacturers the importance of fish culture, to enlist their sympathies, and induce them to concur in the precautions and legislation necessary to check the pollution of rivers by the waste products discharged from manufactories, a chief obstacle to the preservation and propagation of fish.

'Perhaps the most unfortunate thing in the world,' he said in one of the lectures given during this journey, ' is the salmon. Everybody and everything, from the otter to the fisherman, persecutes him. He is naturally an inhabitant of the sea. He runs up the rivers, and would almost jump into the pot on the kitchen fire if allowed, but every effort is put forth to keep him at a distance. He gets fat in the sea, though what his food is nobody quite knows. $\mathrm{He}$ is in the liabit, however, of 
going up the rivers to his country quarters in the mountains, along with his wife and family. Then almost at the uutset, he is caught by a seal lying in wait for him, as in the Tay, for instance. Then comes a net, then a weir, and next a steamer frightens him back; then the refuse from towns forces him to choose between returning and being poisoned. The weirs across rivers are the main cause why our fisheries have fallen off; yet all that is wanted is a fishladder, a series of steps or boxes extending up over the weir. If the salmon succeeds in leaping the weir, he next meets with an angler, who may however fail to hook him; then on arriving at his proposed destination, he encounters the poacher, who tries to spear him with a trident. Escaping him, the salmon at last reach their breeding place, where Mistress Salmon begins stirring up the gravel with her tail, and making a hollow nest wherein to lay her eggs, of which the hard roe of the fish consists, a salmon carrying about 850 eggs for every pound weight. The trout then comes to eat the eggs; next a whole swarm of flies and insects; then the water-ouzel, who goes to eat the flies, is shot by ourselves, under the idea that the bird is after the eggs, and not after the flies. Other enemies come; the jack, and the otter who follows the little salmon on their way to the sea, where the anglerfish lies in wait for them. The result is that not one egg out of ten thousand ever becomes foud for man.'

Wasteful destruction of young fish, by the ignorance or carelessness of fishermen, Frank Buckland also strove to check.

A visit to a fishing weir in July 1866, and the destruction of young fish there, he thus described:- 
'At Hampton, near Herne Bay, there is a weir built out from the foreshore into the sea, and an old man, one Judy (qucere Judah) Downs, has the right of fishing it. Judy lives close by.his weir, in the queerest house one ever saw; it is built upon piles apparently of the jetsam and flotsam of the ocean, a compound of old boats, wrecks of ships, and tarred brown paper. It is on the very edge of the shore, and some stormy night. Judy, house and all, will most certainly disappear from the face of the earth. When at Hampton, on the business of the Herne Bay Oyster Fishery Company, I saw old Judy suddenly poke his head out of his house, like a rat out of his hole, and look at the weir. Seeing that the tide was nearly down, the old man came out, harnessed his pony to a carrying machine (a hybrid between a wheelbarrow and a costermonger's cart), threw two buckets and a landing net into the cart, and trundled down the shingle. I was very soon after him to see the fun, and Judy was kind enough to do the honours. At each corner of the weir is a little private apartment, into which all the unfortunate fish, which happen to be inside the weir when the tide goes down, retire as a last effort. Judy's pony was outside the private apartment, and as I came up I heard a bobbing up and down, as the old man was thrashing away at some live fish under the water. I soon came up, and saw Judy was endeavouring to kill a "curio" which was floundering about in the weeds and mud. "Don't ye go and touch him, sir, he will sting ye, sir; for he is a poison fish, he is." This made me more anxious, and at last the "poison fish" was jerked out high and dry with a long stick, and Judy ran to the cart for a bill-hook. 
"What are you up to now, Judy?" "Up to, sir; why, chop his tail off, to be sure, his poison lies in his tail." "Stop! you will spoil the curio," I shouted. "I will buy him of you if you leave his tail on; but I won't have him if you cut it off." So I watched the poison fish, and soon saw that it was a fine specimen of the 'sting-ray' (Raia pastinace). The fellow is not unlike a common skate, except that he has a brown, slimy, chocolate-coloured skin, and a long tail that tapers to a point like a driving whip. About twothirds of the way down this tail are situated two long sharppointed spines, one above the other. They are shaped exactly like an old Roman sword, and their edges are jagged into numerous fine needle-shaped teeth, placed one above the other, and most terrible weapons of offence and defence they are. The sting-ray knew their power, for whenever he was touched, snap round came his tail towards the intruding object, as quick as a whip lash round a gig-shaft. I put my capture into a nice muddy place, where he could lash away with his tail as much as he liked, and die at his leisure. He did not take things quietly at all, but every now and then tried to raise himself up on his great wing-like fins, and at the same time uttered the most extraordinary groan-like noises, like a man with a very bad toothache. When dead I had a good look at his face. It is like that of a very hideous baby in the act of perpetual crying. His teeth are very small, as though nature had taken out the two largest teeth from his mouth and stuck them into his tail. My friend has since been immortalised in plaster-ofparis.

'Having done with the sting-ray, I returned to Judy, 
who was scraping the fish up in his landing net, and filling his buckets with a wriggling mass. The chief of his capture of slimy fish and eels were what he called "gorebills," that is those curious long-beaked, green-coloured fish known also as "gar-pike." The poor gore-bills were in a desperate state of alarm as Judy gathered them up in his net; they were only young gore-bills, about six inches long, but I afterwards bought an old gore-bill which measured twenty-seven inches long. I immediately stripped off all his flesh and made him quite a skeleton to show his bones, which are of a bright green colour-the green, in fact, of verdigris on an old copper ship; why nature should give these fish green bones, skull and all, I know not, but it is a fact. The fish, moreover, are not poisonous, for I ate half a dozen of them for supper, and felt all the better for it.

'As the tide left the weir, I saw a sight that made my piscicultural heart sad, viz., the destruction of such large quantities of young fry. In the first place, the lower part of the weir was quite silvered with-think, think of it, se epicures! with whitebait, pretty silver and green, largeeyed whitebait, flapping their little innocent tails in the mud, gasping for water, breathing only the fatal air. These are veritable whitebait, the "smig" of the Thames whitebait fishermen, and the young of - well, we want a discussion-Clupea alba, the old whitebait. "Judy, what do you do with these whitebait?" said I. "Oh! I takes no notice of them things," was the answer. "I picks 'em up and puts 'em into a pickle bottle, they are capital bait for eels. See here, sir: this eel is ready to bust with them; eels like whitebait, sir." "So do others besides eels," 
thought I. May not the origin of the word whitebait be thus accounted for? The fish are white, and they are used for bait.

" "Do you catch many of these little fish, Judy?"

" "Bless'e, sir, there is bucketfuls sometimes in the weir, and I just let's 'em lay." "Say no more, Judy, I beg, my feelings will not bear it. But what is all that mass of live things in the corner?" "Oh! them's a lot of little things, they ain't no good." So I shovelled up half a bucketful of them just as they came, and sorted them out. Here is the catalogue.

'Imprimis, Several little soles, the largest about three inches long. 2nd. Many hundreds of little flounders and plaice, from the size of a shilling upwards. 3rd. Among the whitebait were considerable numbers of a little fish, which when alive is transparent: these little transparent fish form a great part of the whitebait put on our tables: the whitebait fishermen call them 'Rooshans,' because they first appeared in the nets at the time of the Russian war: they are the young of the weaver or adder fish, the fish that has three sharp spines on his back, which he can erect at will; they are not uncommon on sandy shores, and inflict severe wounds on the feet of bathers, who tread on them when buried in the sand, as is the habit of this fish. 4th. I found the common sand eel (Ammodytes) and its young just hatched out. 5th. Several tiny thread-like, sharp-billed, jelly-like, long-billed bodies, which are baby "gore-bills." 6th. Curious eel-like fish, with an ugly, pert-looking head, and frill down the back (like the frill to an old beau's dining-out shirt), and a spotted and exceedingly slimy body; their local name is "slippers" 
because they slip from the hand so easily. Lastly, we have many specimens of various curious, ugly-looking small fish, and their young, like miller's thumbs. Here, for once, I agree with Judy that this fish, at all events, " ain't of no account."

"The destruction weirs of this kind must do, if greatly multiplied along the mouths of rivers, must be very great. Judy's weir catches, as we have seen, the young of no less than seven kinds of fish. There are, however, no other weirs near Judy's, and very little trawling outside; so that, after all, the weir, in this instance at least, may be practically as harmless as Judy himself, though the old man did bring an action against the Herne Bay Company for taking away shingle from the foreshore opposite his mansion--a regular centaur among dwellings-half-boat, half-house.'

In this year and henceforward Frank Buckland laboured hard at fish-casting.

'March 6.-Cast the enormous salmon of $70 \mathrm{lbs}$. weight; began at 6.30 and left off at 12.10 in the morning.'

'June 7.-Cast the big carp; sat up to 12.15 to do it.

' $8 t h$. - Began to work at the casting at 8 , and left off' at 8.45 P.M. Finished the big carp, and weighed the roe; it was $3 \frac{1}{2}$ lbs.'

In like manner, remarkable specimens of jack, porpoise, shark, sturgeon, maigre, and other fish, were cast with immense labour and pains, and placed in his museum.

His large fish nursery at South Kensington was also a constant care, and this year met with misadventures.

'April 25.-Water cut off from the fish at the Horti- 
cultural Gardens. Neville called me up at 12.30 ; at the Gardens till 4.15 following morning, but saved many fish.'

France was ahead of England in pisciculture, and, in August of this year, two fishery exhibitions were held in France, at Arcachon and at Boulogne. To each of these Frank Buckland sent exhibits; models of fish-passes, and other apparatus, and a series of specimens of various kinds of orsters, and he received from each exhibition a silver inedal.

At Boulogne he was nominated one of the judges, and wrote thence the following account of the opening proceeding's :-

'Boulogne has good reason to be proud of herself. Not only is she a most agreeable watering-place for loungers, both French and English, but she is the principal sea-fishing port of northern France.

'She has now added fresh laurels to her crown, by this exhibition, which promises so well that entire success seems already to be secured.

'The science of fish-culture, up to almost the present time but feebly supported in England, has been taken up by our neighbours in France in a manner which, speaking as an Englishman, makes me feel quite ashamed of $111 y$ country.

'With all her salmon fisheries, her oyster fisheries, and her deep-sea fisheries, England seems behindhand in bringing her information to a focus, and forming a high 'Change at which ideas and practical information may be interchanged with other nations and with the fishers of the United Kingdom on the all-importint subject of fishcult ure. 
'Things are different on the Continent. Amsterdam led the way, and Bergen followed in shewing to the world that aquiculture was worthy of a place in the school of practical sciences, by the side of her elder sister agriculture. France, with a quickness and foresight which do her credit, seized the idea, and two exhibitions of aquiculture are actually at this moment open in France, one at Arcachon, almost on the borders of Spain; the other at Boulogne, only four hours from Charing Cross.

' Having received an invitation from the authorities of the Boulogne Exhibition to act in an official capacity at this international undertaking, and to co-operate with the committee, I gladly availed myself of the opportunity of forwarding the good cause. . .

'We were informed that the assembly would take place at the Préfecture, in full evening dress. If there is anything that an Englishman abominates, it is a black "claw-hammer" coat (as the Yankees call it) and a white neckcloth at noonday; but we were obliged to submit. The reception was a grand affair; the company assembled in a grand salon, reminding one much of an English levée. The civil uniforms of the town and country authorities contrasted well with those of the officers of the regiments of chasseurs, quartered in the town, headed by the commanding officer of the garrison of Boulogne, a fine old soldier, whose medal-covered breast showed that he had indeed seen long and active service in his country's cause. Besides these, were present some cavalry and engineer officers, and the officers of the two French men-ofwar, the "Cuvier" and the "Bison," which haci come to Boulogne to assist at the Exhibition. The "Cuvier" is, I 
believe, employed in guarding the French fisheries. It is a pretty idea to call her by the name of the great French naturalist. When will the day arrive that our Admiralty will pay a similar compliment to English science, and launch the "Professor Owen" gunboat from the slips at Portsmouth?

'The prebendaries of the cathedral church of the town were also represented.

'The procession through the streets was intended to have been most imposing; but no sooner were we clear of the hali-door than it began to rain steadily, and with a real English determination, as though the clerk of the weather had not been invited, and showed that he intended to put a damper on the proceedings.

' The procession immediately broke up like a flock of wild ducks suddenly scared by a gun-shot. We sounded a trot, and at length arrived at the Exhibition building with our "claw-hammers" thoroughly saturated with rain and our white ties starchless. A canopy had been provided outside the building, and from a rostrum the prefect was to have publicly delivered his address. No sooner, however, was he seated in a wet chair than down came the rain, and also certain uninvited guests, for the winds, jealous of their influence on the fisheries being ignored, put in an appearance in force :-

\section{Venti velut agmine facto}

Qua data porta ruunt, et terras turbine perflant.

Incubuere mari totumque a sedibus imis

Una Eurusque Notusque ruunt creberque procellis

Airicus, et vastos volvunt ad littora fluctus.

Eneid, I.

'The winds fairly beat off the prefect and the com- 
mission from the platform, and the meeting was adjourned inside the building.

'The speeches ended, a procession of the wives of the Boulogne fishermen, who sell in the market the produce of their husbands' toil at sea, entered the hall. They were all dressed in their well-known and picturesque costumewhite caps, red petticoats, lace lappets, embroidered shawls, and enormous gold earrings. "La belle Caroline"-the Belle of Boulogne some fifty years since, now the matron among the fishermen's wives-presented the prefect with a magnificent bouquet of flowers, and delivered an address, which the dear old lady spoke out without hesitation, and with the least possible indication of nervousness.

'At a given signal there came a sudden crash of music, and the Orphéon Musical Society sang a "Cantata" in honour of this important event in the annals of their native town. The prefect then again came forward and declared the Exhibition open.

'The ceremonies over, I was truly glad to rush to the hotel and resume my ordinary day costume. Having been hard at work, in my shirt sleeves, arranging my specimens, this was the first moment I had to examine the Exhibition and its contents.

'Extending the whole length of the roof of the hall, was a gigantic net, the dimensions of the meshes of which were eight inches from knot to knot. One end of the net was formed with a series of hoops, one belind the other, the largest being about ten feet in diameter. From these hoops extended, as it were, wings, ench wing measuring ninety Danish ells, or sixty yards English. This net was, as the Danish representative informed me, for the capture 
of "saal hunde" or "seal dogs." I understand that the net is quietly dragged up to the mouth of the cave, where the seals are, and a pistol being suddenly fired, the seals rush out and are captured. If ever there was a net made which would catch Pontoppidan's sea-snake (the Scoliophis atlunticus of the Americans), this is the one. We must not yet, therefore, despair of sending Professor Oren a slice for his dinner, and a skeleton for the British Museum. That this net is of practical use is evident, as it has at once been bought for the use of northern seal fisheries.'

In September, Frank Buckland again brought before the British Association, at Nottingham, a paper on the culture of a salmon river, and also a report on oyster culture, 'which met with great success.'

In the same month, a public meeting was held at Maidstone, to consider the adoption of measures for stocking the Medway with salmon and other fish, when he carefully examined the Medway, with a view to advise on the steps to be taken. 'This,' he notes, 'is the first inspection I ever made.'

The following extracts from the private note-book of 1865 and 1866 show the simple-hearted, quaint, yet earnest way in which he now regarded his success and prospects in life :-

'I really cannot help thinking, that the Almighty God has given me great powers, both of thought and of expressing these thoughts. Thanks to Him, but I must cultivate my mind by diligent study, careful reflection in private, and intense and quick observation of facts out of doors, combined with quick appreciation of ideas of others. in fact, strive to become a master mind, and thus able to 
influence others of weaker minds, whose shortcomings I must forgive.

'I am like a ship at sea; my instructions are to do good and earn a livelihood. I must carry on board a cargo of information, with a sound ballast of truth, so that when a sudden breeze strikes the sail, and throws the ship on her side, the ballast will right her. There are so many waves-stormy, cold, white-faced waves of opposition-unkindness, and unconcern to encounter, that one need have good timbers.

'Why should not I imitate the example of that great and illustrious man, to whom I owe so much of my education, and especially "manners makyth man," and endeavour to do as much public good as possible in my humble way? I will therefore begin next week, and put ip a storm barometer, for the use of the fishermen at Herne Bay. William of Wykeham had large funds, I have small; but I can do good in my humble way. (I erected this August 1865. It is still up, 1870.)

'March, 1866.-I now am working from 8 A.M to 6 P.M. and then a bit in the evening-fourteen hours a day; but, thank God, it does not hurt me. I should, however, collapse if it were not for Sunday. The machinery has time to get cool, the mill-wheel ceases to patter the water, the millhead is ponded up, and the superfluous water let off by an easy quiet current, which leads to things above.

- December 16, 1866.-To-morrow is my birthday, and I shall be forty years old. I have much to be thankful for to the Almighty. I have good health and a mind gradually improving and consolidating. I have been through much; but, thanks be to God, I have preserved is 
straight course to the best of my abilities, and thongh I see others taking short cuts, I think honest dealing and true is the safest ballast to keep the ship in trim, through the sea of difficulties and dangers. If I have health and strength, I shall persevere in this course.

'The ship is still in good order, ballast not shifted, and the blocks run well; for all this I am most gratefu] to God, without whose assistance I could do nothing. From Him, of course, all, I know, proceeds; I trust He wll continue to pour down His mercies, and I will do my best to fight His cause for Him, and to do my duty to $\mathrm{my}$ fellow-creatures.' 'Laus Domino.' 


\section{CHAPTER IX. \\ INSPECTOR OF FISHERIES : 1867.}

BEFORE 1860, the sea and river fisheries of England and Wales were little cared for. The old Fishery Acts, which, from Magna Charta downwards, forbade the obstruction of rivers by weirs, and the destruction of fish by means impolitic and unlawful, had become practically obsolete. At the river's mouth, and on the higher banks, men strove to take every fish which entered the river, witl little forethought for the preservation of the fishery; while mills and mines, multiplying with the increase of trade, stretched weirs across rivers, barring the salmon from the higher waters, where lie the spawning-beds, or poured poisonous refuse into the stream and killed the fish.

In 1860, the decline of the English salmon fisheries had become so notorious, that a Royal Commission was appointed to enquire into its cause, and devise a remedy.

In Scotland, the rights of great landowners, aided by local statutes, had preserved salmon fisheries to the value of $300,000 l$. a year.

In Ireland, the exhaustion of the fisheries had already led to Acts being passed in 1842, 1848, and 1850, under which these fisheries were reviving. 
The success of this legislation, though partial, enforced by numerous petitions to Parliament, led to the appointment of the Commission of $186^{\circ}$

The Commissioners reported in 1861, that the considerable diminution of salmon in the rivers of England and Wales was fully substantiated. In some rivers the fact was patent and notorious. Salmon formerly abounded, but had almost or altogether ceased to exist. The instances of extinction were but few, diminution, in a greater or less degree, existed in every river visited. In some rivers the supply of fish was not more than one in ten, one in twenty, or even one in one hundred, compared with what fishermen could recollect. Weirs, fixed nets and fish-traps, insufficient close time, pollutions, destruc tion of unseasonable or of immature fish, the want of an organised system of protection, and confusion and uncertainty of the law, were the chief causes of the decrease of the salmon fishery.

For remedy, the report, supported by copious evidence, recommended the appointment of permanent Inspectors, aided by local Boards of Conservators; and also advised a more uniform annual close time, the establishment of a weekly close time during the fishing season, allowing the passage of fish to the breeding-grounds, and the regulation or suppression of fixed nets and other injurious modes of fishing.

The Salmon Fisheries Act of 1861 followed, which authorised the appointment of two Inspectors of Fisheries for England and Wales, and carried out, generally, the recommendations of the Commissioners.

Mr. William J. Ffennell and Mr. Frederick Eden 
were appointed the first Inspectors. Mr. Ffennell was one of the Commissioners on whose report the Act of 1861 was passed. He brought to his new office a practical experience of many years, acquired as Inspector of the Irish Fisheries. Their common tastes had already made him a fast friend of Frank Buckland, who many times accompanied him on his official inspections, both in Ireland and in England.

The Act of 1861, notwithstanding some defects, was received with general favour, and in 1864, the Inspectors reported, that the manifest increase of fish, within so shurt a period, was greater in many waters than the most sanguine had anticipated.

Associations for the protection of salmon in the upper waters, which had languished so long as the increased number of fish fell into the toils of fixed nets, unchecked at the river's mouth, were now reviving, and the weekly close time enforced by the Act was more than compensated by the greater abundance of fish which it produced.

An amendment Act, in 1865, appointed Commissioners to ascertain what fixed nets and traps should be sanctioned, and authorised the division of the country into Fishery Districts, with Boards of Conservators empowered to impose and administer licence duties.

In 1866 Mr. Eden resigned, and in February 1867 the appointment of Inspector of Fisheries was conferred on Frank Buckland. The candidates were numerous, but none will question the wisdom and justice of the choice, for which natural genius and enthusiastic devotion to pisciculture alike marked him out.

To himself the appointment was, as his Diary shows, 
the realisation of the wish of his life, and a subject of unaffected delight.

'Wednesday, February 6.-This day I was appointed Inspector of Fisheries. I lad been invited to dine at the Piscatorial Society in St. James's Hall, and was sitting on the left liand of the chairman (Mr. Sachs), when John brought me in a letter as follows:- " Home Office, February 6,1867. Sir,-Mr. Walpole has desired meto inform you that he has much pleasure in appointing you Inspector of Salmon Fisheries in accordance with your wishes. I am \&c., S. WaLPOLE." -When I read this I felt a most peculiar feeling; not joy, nor grief, but a pleasurable stunning sensation, if there can be such a thing. The first thing I did was to utter a prayer of thanksgiving to Him who really appointed me, and who has thus placed me in a position to look after, and care for, His wonderful works. May He give me strength to do my duty in my new calling! I said not a word to anybody, but in a few minutes I had to make a speech, to propose the health of the prize-givers. I alluded first to the cultivation of the waters, and then to my excellent father's endeavours to do good, saying it was my wish to honour his name, and do my own duty in my generation. I then read out the letter, which was received with great applause. Thus, then, I have gained the object of my life. Surely fortune favours me with great luck; and I am very thankful for it. When I got home I found the house in a state of uproar; all the servants, the monkeys, Danny the little dog, the parrot, and the cat, with paper favour's on; M. and L. were also here with fivours on, and all much delighted at my appointment.'

His new duties were entered upon with characteristic 
energy, yet without relaxation of literary and other work, and care for his museum.

On February 12, he went to the Fishery Office for the first time. 'Wrote a great lot of letters, used up all the old man's papers, and knocked out the bottom of his inkstand. He seemed astonished at the number of the letters. Made cast of the big $38 \mathrm{lb}$. fish sent me by Quelch, who came in to see him cast; began at 9 , finished at 1 .

' 13 th.-To the Fishery Office, and stayed till 4.

"14th._."Land and Water" Dinner; Mr. Coxe in the chair. All went off well; thankful I was in excellent humour for it, surrounded by many excellent and kind friends; I thank God for it. Englishmen as well as Persians worship the rising sun. Set up paper, then to the Office; gave an opinion about Fishery districts ; came back by 4 , and wrote some forty letters.'

On February 18, he made his first official inspection on the river Exe, naturally a fine salmon river, and in the reign of Queen Elizabeth 'fluvius piscosissimus, 'but for many years almost barren. In seven days he examined the river throughout, noting each of the eight weirs which had ruined the fishery, watching and enquiring into the habits of the salmon, the points where they assembled below the weirs, and their struggles to gain the higher waters; and contriving the best mode of enabling the fish to surmount these barriers. This was but the beginning of labour; to get his suggestions adopted throughout the river took years.

In 1869 , he endeavoured, by a field lecture to the Naturalists' Club of Exeter, to urge on the cultivation of the Exe, passing from weir to weir, and discoursing on the difficulties of the salmon. A grant in aid of the salmon 
ladders, from the Town Council of Exeter, followed. Several years later, the fish-passes were still only in course of construction; but in 1875, the fishery had considerably improved, and about three thousand salmon were taken.

On March 12, 1867, Mr. Ffennell died, and Mr. Spencer Walpole was appointed Inspector of Fisheries in his place. In July 1867, the new Inspectors made their first annual reports.

Frank Buckland's annual reports to the Home Office, commencing this year, and continued to the end of his life, contain a vast amount of varied scientific and practical information, relating to the river and sea fisheries of Great Britain.

They form not only a record of indefatigable work, but a storehouse of facts, and experience, and practical suggesfions, stowed away in the uninviting and little accessible form of blue books.

Some extracts from them may illustrate his work as Inspector of Fisheries.

The salmon was his chief care, whose strange migratory habits distinguish it from other fish, and require special provision. Most fish live either in fresh or in salt water, the salmon inhabits both. Bred in the higher waters of our rivers, the young salmon of one, two, or three years' growth, make their way down to the sea as smolts, and return thence, impelled by the instinct of reproduction, to seek the gravelly spawning beds in the mountain streams. In early spring, and through the summer and autumn months, they come from the sea, bright coated and silvery, and swim and leap and struggle up the rivers; then is the fisherman's harvest. In winter the spawning time comes 
on, when the laws of nature and of man alike forbid their capture, for the fish, at other times so rich a luxury, are now vapid and unwholesome. Lean and flabby after the breeding time, the males with hooked beaks and scarred in fighting, the spawned fish or kelts rush down again to the sea; whence after awhile they return, fresh and silvery: fattened to twice their former weight, and re-enter the rivers as fresh run fish, the joy alike of the fisherman and the epicure. Whither they go in the sea, how long they stay, what they fatten on, are questions still unsolved, since trawlers and sea fishermen do not meet with them, and, from the time they escape from the river till they re-enter the estuary, their dwelling place and habits are unknown.

It is believed that the instinct of the salmon leads it back to the place where it was bred; ' and I hope it is true,' Frank Buckland used to say, 'for many thousands have been hatched out in my kitchen.'

These singular habits of the salmon make the productiveness of each fishery dependent upon free passage being preserved for the fish from the sea to the higher streams, and upon such due regulation of the fishing as may allow a fair proportion of the fish to reach the breeding grounds, and prevent their total extermination on the way thither. To these ends the provisions of the Fishery Acts and the care of the Inspectors were directed.

In his first report Frank Buckland summed up the results of the previous six years' working of the Act. In twenty-four rivers a great and marked improvement had already taken place. In eleven rivers there was a gradual improvement; in seven, little or no improvement; and in 
five others sufficient time had not yet elapsed, since the Act had been put in force, to give definite results.

'So far then,' he continues, 'the upward course in the development of the English salmon fisheries is most satisfactory, and cannot fail to be a source of congratulation to all interested in the subject. In order to gain further improvement, I now propose to consider the causes of failure, causes which apply equally to all rivers, and upon which all future salmon cultivation and legislation must depend. The problem before us is to cultivate the largest quantity of salmon in a given area. Nature has ordained laws which regulate the habits of this most nutritious and valuable of migratory fish. In order that salmon should multiply its species, three things are absolutely necessary. First, suitable breeding grounds; secondly, suitable feeding grounds; and thirdly, a free and uninterrupted passage from the sources of the rivers to the sea. Were all these conditions combined, without let or hindrance, and the enemies of the salmon at the same time kept in check, there might hardly be any limit to the number of fish available for human food.

'In the first place, salmon must have pure water. They cannot exist in poisoned streams, any more than human beings can exist in an atmosphere of carbonic acid gas. The attention of the salmon cultivator should be, therefore, before all things, directed to the state of the water in which his fish have to live and be reproduced. There are five rivers in the happy condition of having no pollution, viz. the Otter, the Ribble, the Lune, the Glaslyn and the Conway. On the contrary, other rivers are affected by pollutions, as follows:-By gas, five; by paper, six; by 
lead, six; by mines, five; by coal-dust, three; by sewage, three; by tan, three; by oil and alkali, two; by wool, two; by dye, two; by carpets, chemicals, \&c., three.

'Water is as indispensable to the human being as it is to the fish. Impure and polluted water will encourage disease, especially cholera; pure water will disarm disease of its power, and at the same time be available for growing excellent human food, in the form of salmon and other fish. Thus, then, it will be seen that the question of pollution of rivers affects not only the salmon, but every individual among us; and the question assumes a far greater public importance, than if it were applied to salmon alone.

'After pollutions, the most important question is that of allowing the adult fish to reach the spawning beds, wherein to make its nest, at the sources of the rivers; and to secure a free and uninterrupted return to the sea for the infant salmon, as well as for its parents. This naturally leads to the question of obstructions, both natural and artificial. I grieve to say, that our rivers report obstructions formidable in number and formidable in construction. Thus, Severn and her tributaries report seventythree weirs; Derwent reports eight; Taw and Torridge seventy (forty miles of beautiful spawning ground blocked out!) ; Dee reports five on the main river, and many on the tributaries; Wharfe, fifteen; Ouse, two; Ure, four ; Nidd, eight; Swale, six; in fact, most rivers report obstructions more or less, and but few report no obstructions.

'The interest of the millers, the navigation proprietors, and others for whose benefit these obstructions (as we friends of the salmon choose to call them) have been 
built, certainly should be considered, as well as the interest of the fisheries. A river serves two purposes; it may, firstly, be made to work milling power; and secondly, it may be made to produce fish. In many instances, at the present moment, these two objects are incompatible. I do not see that they are really so; and feel convinced, that if conservators use their ingenuity, and co-operate with the owners of weirs, mills, \&c., both objects may be gained, particularly if a friendly spirit be brought to bear upon the question.'

To give passage to the salmon without injury to the miller or his weir, many salmon-ladders had been erected. A sloping trough with frequent bars across gave the principle of a water-ladder, moderating the flow of water, and forming a series of pools from one to another of which the salmon could swim or leap, and so pass over the weir. But many fish-ladders had proved useless, since varying weirs required different forms of fish-pass.

Frank Buckland, in his first report, gave general rules for their construction; pointing out especially that they must be adapted to the habits of the salmon, and should therefore start from that part of the pool beneath the weir where the salmon are found to congregate. They should have a slope six or eight feet in length for every perpendicular foot of fall, and be protected at the top by a Vshaped board from any undue rush of water which might throw down the fish into the pool below.

'The third item necessary for the well-being of a river,' he continued, 'is the protection of the parent salmon when engaged in the duties of spawning, and that they should be allowed a free and unobstructed ascent from, and 
descent to the sea, at all seasons of the year. When at the nest, if the parent salmon be destroyed by a poacher, one fell blow will annihilate many thousand fish in the form of eggs.'

The report also pointed out the wastefulness of the capture of spawned fish or kelts when unfit for food; as an example of which he placed in his museum the cast of a kelt found dead in a pool, that measured 39 inches, and weighed $10 \mathrm{lbs} .2 \mathrm{oz}$; with another cast of a fresh run fish of exactly the same length, which was found to weigh $20 \mathrm{lbs}$, or almost double the weight of the kelt.

In June 1866 he had taken part in a congress, held in London, under the presidency of Lord Percy, of conservators and others interested in salmon-fishery questions, at which a considerable number of working models and plans of salmon-ladders were submitted, the details of which are discussed in the same report, with this practical conclusion : 'I would remind conservators that, in all cases where it is possible, they should use their ingenuity in trying inexpensive experiments, utilising as far as possible the available and cheap material of the country, in order to get principles upon which the permanent structure may afterwards be erected; and I shall only be too pleased to assist this idea in any way in my power, either mentally or bodily, for it is a painful thing to find that after an expensive ladder has been built it will not act. We must not, however, forget that the ultimate verdict of whether a salmon-ladder be good or bad must be left to the decision of the salmon themselves; all we can do is to find out what they want, and accommodate them to the utmost of our powers.' Before the next annual report, he had persoually 
examined twenty-six salmon rivers, with the like care he had bestowed on the Exe. Of one of these rivers, he says: "The Canterbury Stour is now under cultivation. In the commencement of 1866 , I gave a public lecture in the city of Canterbury, on the cultivation of salmon rivers: at this lecture most of the influential gentlemen of the neighbourhood were present, and I think I can fairly say, without boasting, that this lecture was the commencement of the formation of the Stour into a fishery district.'

This river was strongly fortified against the incursions of salmon. An outwork of stake-nets stretched into the estuary. Higher up, at Fordwich, a grating was thrown light across the river with a trap net in the middle. Abore, two mill weirs formed impassable ramparts; other mills and weirs barred the higher waters.

The stake-nets were put under supervision, the grating was abolished, a fish-pass was erected at the first weir, at a cost of over 50l., on what was then known as the Government principle; but it proved defective in action; the fish met in conclave at the bottom and gave their verdict against it. The defective mechanism of the ladder was under an archway, and could not be seen without descending into the ladder, and crawling down the arch. This, to Frank Buckland, was a labour of love; his sympathy with the sulmou soon discovered and cured the defect, and then, at a cost of but $15 \mathrm{l}$, he placed a cheap and simple ladder over the upper weir, which the fish fearlessly swam up, as if they knew it was planned by their best friend.

The artificial hatching of salmon and trout was also introluced in the Stour ; but while the trout increased 
considerably, the number of salmon has been checked by the pollution of the river from the sewage of Canterbury.

A similar cause prevented the success of his endeavours to re-introduce salnion into the Thames, where they were once plentiful. Many thousand young salmon were reared at Hampton, and turned into the Thames; but owing probably to the impurity of the water, and its disturbance by steamers and ships, only one or two salmon have been taken in the Thames in recent times.

'The difficulty of dealing with weirs,' lee wrote in 1868 , 'seems to resolve itself into a question of bread $v$. salmon. Many of the mills are corn mills; the public require bread; the miller's business therefore becomes important, and in one sense even more important than salmon. For my own part, I conceive that (failing compulsory legislation) if a system of "give and take" be established, the public will have their usual amount of bread from the mills, and an increased supply of salmon from the rivers; the property of the miller will not be interfered with, and the property of the fishery proprietor will be more fully developed. This is to be done hy arranging that the salmon shall have the use of the water when the mill is not at work, i.e., let the miller utilise the water during the day, but allow the salmon to utilise it during the night. The miller will then have the use of the water, for his own interests, during six days, and the fish during six nights; the mill does not work on Sundays; on that day, therefore, the water should be given up for the use of the fish. I do not wish that the weirs should be destroyed; I wish only that a free passage over them, by means of an effective ladder or pass, should be made compulsory.' 
The Act lad dealt with fixed engines, and with the close time, but gave no compulsory powers to alter weirs or place fish-passes over them. These the inspectors could advise and recommend, but had no power to enforce. But Frank Buckland's enthusiasm was singularly infectious, and there is an innate love of sport in most Britons; so he visited the landowners, chatted with the millers, and smoked with the fishermen, for high and low were alike his friends if they loved nature, and especially salmon, till he bound them together with the common purpose to preserve and multiply the objects of his care: and thus fish-passes were by degrees laid over weirs, and sluices were opened, when the miller found his purse would not suffer, and salmon leaped and splashed again in pools which had long been silent, and the food of the people was multiplied.

One example may be given of his happy way of conciliating opposition by a union of good sense and good humour, making his subject simple to every understanding, however rustic, and while raising many a hearty laugh, impressing all with a sense of his own earnestness.

He seemed to have power to charm the reluctant; many who came to listen, suspicious, dogged and perverse, soon yielded to his genial tact and wit, and became themselves inflamed with piscicultural ardour.

The inspectors lield a meeting at Maryport in August. 1867, to endeavour to enfranchise the river Ellen, then encumbered with mill weirs, and to induce the millers, though jealous of their rights, to co-operate in freeing the river from obstruction.

'You have,' he said, 'a beantiful preperty in tho 
river Ellen; because nature favours it. Fight against nature, you will be beaten; go with her, she will assist you. The salmon is a very clever fellow. A gentleman at the British Association produced in a glass some brains, which he said were the least developed of any that could be found! They were salmon's brains. I said, "I will not hear my friend assailed, and I will back the salmon against you." To cultivate a river, you must study intimately the habits of the fish. A river is like a railway. Lay a line from London to Carlisle without break, the train will go straight through, but if a rail is placed across the line, over goes the train. So with a river. If the river is clear, a fish will rush right up; but if a weir is placed across, it stops him. The river Ellen has admirable spawning grounds, and a natural supply of fish, but they have been exterminated. The principal enemies are those abominable weirs, and particularly one curled over like a lady's chignon, and a horrid-lonking one it is. Imagine yourselves to be fish, in close season. How would you make your way up the river? You would not jump the weirs, you could not get over them. The fish want to get over them into the upper stream-not for the benefit of men, but on their own business; but men have told the fish that, although so valuable, they shall not come. The millers have built the weirs to turn the mills, and stopped the fish; but with a little ingenuity the miller may drive his mill, and the fish pass every weir as well; so that both fish and miller may make proper use of the river.'

Describing each weir and the remedies to be applied, he continued :-

'The principle is very simple after all. We often 
go gaping about while the truth is staring us in the face. How have we all come into this room? If we had been outside and smelt the smell of dinner, we might have tried jumping in at the window, but we found that the landlord had made us a staircase, and when we got to the top of the staircase we opened the door. So the fish assemble in the pool, they jump and jump, and cannot get over. Now what have the improvers of the river to do? They have to open the door-that is the sluice-and the fish will go through.

'I see present our friend the miller. Now I have a sort of dread of millers. When inspector's go to examine weirs, and see a white cap coming across the field, they say, "Oh, here comes the ogre of the weir, who destroys all the salmon." I confess it is a satisfaction to me to see the miller get pelted with flour in the pantomimes. I must say, however, that Cumberland millers are the best fellows I ever met. The first miller we met to-day has opened a fish-pass, and promises in winter time to open the sluice every night. That will beat any ladder we can make.

'At Dereham my excellent colleague, Mr. Walpole, has shown us what to do. It is to make a pool, and pool-making is a very simple business. Supposing that our weir is six feet high; if a fish cannot jump six feet, it can jump three. In order to jump, the fish must have a deep pool from whence to spring; he takes a long run in the pool, and comes up from the deep water like an arrow. The way to give deep water is to build a wall about three feet high; the water will fill it up into a pool, and instead of having six feet, the salmon will bave only three feet to jump. 
'Next we come to Birklery weir, which is a puzzler. If I were a fish and got up to Birkley, I should say, "Goodmorning, gentlemen; you treat me so badly that I shall go back again." Then we come to Ellen Grove. It is quite a treat to see the ladder there; it is very good, not quite perfect; but if I were a fish I should go up, because they have made the staircase very easy. There is a pool at the bottom of the weir, and the fish can stay there all day, and perhaps say, "Here are the inspectors coming, and I hope they are going to keep down the poachers." There is another enemy to be found at Birkley weir. Not a miller but a tanner, and that is next door to a miller. I said to the tanner, "You have been brewing some porter this morning;" but the tanner replied, "It is onl lime water." I asked the tanner if he could not put his lime somewhere else, and would it not be better to put it on the land and let his cabbage eat it? Now, there is a certain public spirit in every English breast, which will always make him draw back a little when the public wishes it; so I said to the tanner, "Please oblige those gentlemen of Maryport, and don't throw that lime into the river :" and the tanner replied, "No, I won't! I will throw it on my midden."

'Now Mr. Senhouse holds a most important position on the river; he has the key of the front door; the upper proprietors have the bedrooms and dressing-rooms and attics. If you do not unlock the front door, it is of no earthly use opening the other doors. The fish must be got over the weir at the entrance of the river: it must be done.

'When Lord Palnerston passed an Act of Parliament 
compelling manufacturers to consume their smoke, gentlemen came and said, "It can't be done." Lord Palmerston replied, "I don't know whether it can or cannot be done, but it must and shall be done." Mr. Senhouse will see at once the importance of opening the weir and allowing the fish to get up the river. If a salmon comes there and sees no obstruction, he will go up the river as straight as he can go for the spawning-grounds.'

How wide the field was for improvement in the salmon. fisheries appeared from calculations quoted in the report for 1868. On seventeen salmon rivers, salmon were excluded by weirs or pollutions, or both, from an area of 11,600 square miles, leaving accessible to the salmon in those rivers an area of only 6,600 square miles.

Despite weirs and pollutions, and the vis inertice of habit and prejudice, salmon multiplied to a marked extent.

The annual sales of Scotch salmon in Billingsgate Market, as quoted in the report for 1868, averaged 1,100 tons; fluctuating in different years from 750 to 2,100 tons. The sales of Irish salmon in Billingsgate, in the eight years preceding the Irish Fishery Act of 1842, averaged 83 tons a year; in the twenty-six following years to 1867,270 tons a year; and in the following nine years, 350 tons a year. The yearly sales of English and Welsh salmon at the same market, in the ten years preceding the Act of 1861, averaged about eight tons only. In 1867 , the yearly sale had increased to an average of 50 tnns, and in the following nine years to an average of 88 tons. The total annual sales of English and Welsh salmon throughout the country was estimated in later reports to have increased to $100,000 l$. in value. 
To accomplish these results required ceaseless personal exertion. To stir up the inert, to combat stolid prejudice, to harmonise conflicting rights, to infect others with a spark of his own enthusiasm; this was Frank Buckland's daily task.

His museum also occupied much time and labour. 'Being exceedingly anxious,' he wrote in his second report, 'that the public should have a good idea of the nature and importance of the British Salmon Fisheries, I am happy to be able to report, that I have now got together a Museum of Economic Fish Culture; and my collection is open free to the public at South Kensington. The natural history of the salmon, as well as of other products of the waters, of economic value, especially the oyster, is illustrated by plaster casts and preparations, all of which I have made myself, and mostly at my orn expense. There will be found in my museum models of salmon passes, and modes of salmon capture, nets, \&c. The process of hatching the ova of salmon, trout, \&c. is also carried on at the Gardens on a considerable scale. This is now the third year that I have been enabled to distribute, on the part of the Acclimatisation Society, a considerable number of ova to various rivers in England. Although the judicious cultivation and opening up of natural spawning-grounds will, in my opinion, be alwars preferable to hatching the Salmonidoe by artificial means, yet, inusnuuch as the transport of large numbers of salmon and trout in the embryo state, to places where they did not exist before, and also improvement in the breed of fish, may be readily effected by the artificial process, I trust 
that my efforts have done good, and will continue to do so for the future.'

Casting fish for the Museum was no easy matter. This is 'How we cast the large Sturgeon' in April 1867 :-

'On Tuesday evening, about 5 P.M., Messrs. Grove of Bond Street sent word that they had a very fine sturgeon on their slab. Of course I went down at once to see it. The fish weighed, I was informed, 212 lbs.; it measured 9 feet in length. I was anxious to make a cast of this fine fellow, but I confess the size and weight rather frightened me; however, they offered me the fish for the night; he must be back in the shop the next morning by 10 A.M. Determined not to lose the chance, I called a cab, and we tried to get the sturgeon on the top of it, but he was "too much" for us, and we were obliged to give up all idea of this mode of conveyance of our huge friend from Bond Street to Albany Street. Messrs. Grove then kindly sent him up in a cart, and we got him out of the cart easily enough on his arrival at my door, but it was with the greatest difficulty we hauled him up the doorsteps. We then thought of pitching him headlong over the railings into the area below, and thus getting him into the little front kitchen, which, though terribly small, I use as a casting-room; but his back was so slippery and his scales so sharp to the hands, that Master Sturgeon beat us again. However, I was determined to get him down into the kitchen somehow; so, tying a rope to his tail, I let him slide down the stone stairs by his own weight. He started all right, but, "getting way" on him, 
I could hold the rope no more, and away he went sliding headlong down the stairs, like an avalanche from Mont Blanc. At the bottom of the stairs is the kitchen door; the sturgeon came against it "nose on" like an iron battering ram; he smashed the door open in a moment with his snout and slid right into the kitchen, gliding easily along the oil-cloth till at last he brought himself to an anchor under the kitchen table. This sudden and unexpected appearance of the armour-clad sea-monster, bursting open the door-shut purposely to keep out the sight of "the master's horrid great fish "-instantly created a sensation scene, and great and dire was the commotion. The cook screamed, the housemaid nearly fainted; the cat jumped on the dresser, upsetting the best crockery; the little dog Danny, with tail between his legs, made a precipitate retreat under the copper and barked furiously; the monkeys went mad with fright, and screamed "Murder" in monkey language; the sedate parrot's nerves were terribly shaken, and it has never spoken a word since; and all this bother, because a poor harmless dead sturgeon burst open the kitchen door, and took up his position under the kitchen table. Worse than all, I was obliged to go out to dinner that night: but, nevertheless, before leaving the house, I managed, with ropes and improvised mechanical contrivances, to get the sturgeon on the table of the casting-room, and piped all hands to work. My secretary took charge of the moulding, and worked well at it. Before 2 in the next morning the mould was made, and before 10 the sturgeon was back again on Grove's slab. Now comes the difficulty. How am I ever to get the cast out of the little room? It will be too wide to 
pass out of the door, and too long to twist round so as to slew it out, and solid plaster will not twist like the pliant body of the fish itself. I can't get it out of the window on account of the iron bars let into the stone-work. Robinson Crusoe built a boat of wood, and made it so heavy he could never launch it. I am much in the same predicament with the cast of my sturgeon, but I never was beat yet by a fish, even though he be a cumbersome monster like the present occupant of my casting-room.'

The large sturgeon was, however, eclipsed a few days later by the arrival of a whale.

'I am happy to say,' he wrote on May 4, 1867, ' my whale has at last arrived. Early on Saturday morning last, I received a note from Mr. Bartlett of the Zoological Gardens, saying the whale was awaiting my immediate inspection, having just arrived from Edimburgh. Having previously obtained leave from Dr. Murie, the prosector of the Society, to make use of his dissecting-room, we shot the whale bodily out of the van, and placed him on the asphalte floor. It was a fine whale, but not so large as I should have wished. The largest of those captured in the Firth of Forth, at the beginning of the week, was 25 feet in length, whereas my specimen measured $11 \mathrm{ft} .6 \mathrm{in}$. in length, and $7 \mathrm{ft} .6 \mathrm{in}$. in girth. There can be no doubt, I think, that my specimen is Globicephalus decluctor, or the ca'ing whale. His head resembles somewhat a huge round glass carboy as used by wholesale chemists, or the forehead of a person afflicted with hydrocephalus. I cannot say his colours are well marked, as his whole body is simply like a mass of indiarubber, shaded off to a narrow line of. olive green on the belly; the body is likewise elastic and silk-like to the 
touch like india-rubber. His eyes are very small, in fact almost invisible. His fins are tapered, and in shape not unlike a pair of ladies' gloves folded before they have been put on. His back fin is curved somewhat like a Turkish scimitar, and its lower edge ends in a sharp ridge, which runs the whole length of the body from the back fin to the tail. The teeth, twenty-eight in number, are conical, and slightly set in their sockets. The tongue was projecting somewhat from the mouth; it is dark blue above and red below. It is said to be good eating. The Shetlanders call this whale the ca'ing whale; ca'ing is the Orkney for "driving" (i.e. on shore). It is called deductor from its peculiar habit of following a leader, the main flock following a leader like wild ducks in the air. The Shetlanders from this cause call it the "leading whale;" at Faroe it is called the "guard whale." They are harmless, inoffensive creatures, and I should imagine excessively stupid, as they are continually running ashore, allowing themselves to be murdered wholesale. Their food, I believe, is fish. They are very fat and make very good oil; the blubber upon this creature was cut off in masses, like great folio books 4 inches thick, and sent away to be boiled into oil. The flesh was of a very dark red colour, much resembling that of a horse. Having obtained a vanload of plaster, I determined to devote the usual half-holiday of Saturday to casting the whale. It was perfectly impossible to cast it in one piece, as it weighed a ton. We therefore made the mould in six pieces, and it was wonderful what an enormous quantity of plaster it took to do this. I had, lowever, very able assistance from my friends. Some came simply to look on, but I told them either to go away or to 
strip and work; one by one they took off their coats, got their hands whitened with plaster, and set to work like men. After a while we got the whale entirely covered up with plaster, white and glittering like a huge twelfth cake covered with sugar; but then came the difficulty of getting the moulds off again. The very first piece showed me something was wrong. Alas! the plaster was all cracking like unsafe ice. We therefore had to begin all over again, and put another coat light over it, so that when the mould was ultimately taken off, it was of the thickness of armourplating of an ironclad. This done, we got the head and sides off right enough, but when attempting to turn over the largest portion of the mould, about 9 feet long, one side, without the least warning, gave way in the most aggravating manner, and crumbled like a piece of pie-crust. This was the result of the tradesman, from whom I had the plaster, being cruel enough to supply me with a rery inferior kind, which, he must have been well aware, was good for nothing. Luckily the side broke in pretty large pieces; so we managed, with difficulty and much contriving, to put them together again. All this took a long time, but I was determined to finish the whale that night, as I did not know when I should have time to touch it again. Having rested a few minutes, we all set to work to cast it from the mould; and, to make a long story short, I finished it completely before Sunday morning, getting my Saturday's dinner at five minutes to 12 at night, and most thoroughly I enjoyed it after so many hours' heary work. On Monday afternoon I got a van which just held the pieces of the whale, and, with great labour, we managed safely to deposit the ponderous masses on the vacant space 
of ground near to my museum at the Horticultural Gardens. I hope, at the first leisure time, to be able to put the pieces together and to complete this specimen, which I know is the only cast of a whale in London.'

Both casts of sturgeon and whale were at last completed, and are now in the museum.

Another incident of the same year is thus related:-

'This summer I enjoyed the privilege of seeing Captain Salvin's cormorants work in the river Test. The miller put down his hatches for the cormorants to work in the pool. The birds had not been in this pool a moment before we saw them hunting a large fish round and round under water; the fish was so large they could not swallow it, and there was a regular set-to under water (like a steam-engine gone mad at the bottom of the river), between the "Detective" and "Hoang Ho" (the cormorants) and the fish. I could stand it no longer, so I jumped into the water, and went to the assistance of the birds. The birds and myself had two or three good courses, and at last the poor hunted fish took refuge under some boards, which formed the apron below the hatches. "Hoang Ho" kept pecking at him with his beak, but could not reach him. I then went in still deeper into the water, and, putting in practice my usual method of catching fish with my hands, I soon had master fish out; to my surprise it was a grayling, weighing nearly 3 lbs. When I first got hold of him, he fought uncommonly hard, and his scales were very slippery; he was a strong fish and no mistake. At last I landed him on the bank, whilst our friend Salvin greeted us with loud shouts, and vehement cracks of his cormorant whip. The only 
person not pleased was the miller, who said "he never see $d$ three such poachers in his life in the water together, as them long-necked birds with straps round their necks, and the gent as ought to have a strap round his'n."

Hedgehog's, whose habits he had described in 'Curiosities of Natural History,' ' again gave rise to a lively correspondeace :-

"My friend, Mrr. Gilbanks, said at a public dinner the other day at Maryport, that " he and I had had many a passage at arms, but that we were none the worse friends for that." I now, therefore, again call on the squire to draw his sword. Protocols have failed, and it is a casus belli in re hedgehogs. I have tried hedgehogs to kill beetles; they don't act. A hedgehog cannot possibly hold above a pint of beetles at a time, and in my kitchen there are gallons of them.

'I once tried the hedgehog plan at the Deanery, Westminster. The first night after his arrival, the Abbey watchman was frightened out of his wits--it was the liedgehog. The next night, fast asleep, I felt a cold nose on my face, and then a prickly thing trying to get into bed-it was the hedgehog. The next night, the servants came trembling to say there was a burglar in the diningroom rattling the plate-it was the hedgehog. The next night, the cook put some soup away, and in the morning the soup was gone-the hedgehog was found coiled up asleep in the tureen. 'The next night, nothing was heard of the hedgehog, and for weeks we could not tell where he was gone. The cook was thankful, and the crickets sang "O ! be joyful," while the blackbeetles had free run of the 
kitchen. "Years rolled on," as the novelists say, and a skeleton was discovered in the flue, which had smoked the whole house out for weeks. The hedgehog again! Thank goodness I have seen the last of that wretch, and never wish to have another of his kind on the premises.

' Unless, therefore, my friends wish to run the chance of a hedgehog becoming the same pest to them as he was to me, they will never introduce him into their houses. Hedgehogs will only eat a certain number of beetles, and the beetles having good spawning-ground behind the kitchen range, breed much faster than the hedgehog can eat. Again, good squire, who told you that tortoises ate beetles? Surely nobody but the London costermonger who wished to sell you one. We might as well shut up the squire himself in his own kitchen to eat blackbeetles, as shut up a tortoise to perform that task. If my statement is doubted, shut up a tortoise with a dozen blackbeetles: I warrant the dozen beetles will remain there till the tortoise dies of starvation, and it is then exceedingly likely that the beetles will eat up the tortoise.

'Finally, the squire says hedgehog's are good to eat; he is quite right there. If he will kindly give me a fortnight's notice of his next visit to London, I will put up a nice young hedgelıg to fat, and we will discuss the whole matter over a roasted urchin.'

Hedgehogs gave rise to another debate: whether or not they were susceptible of poison.

'When studying chemistry at Giessen with Professor Liebig,' Frank Buckland wrote, 'we tried this experiment, nd it was fatal to the poor hedgehog. I have also tried hedgehogs and vipers. The viper struck the liedgelogr 
two or three times in the face, where there were no bristles; the blows were well aimed, and meant to do business, as at the moment the hedgehog was munching up the viper's tail. The hedgehog did not suffer in the least; on the contrary, he ate up the viper in a fow minutes, leaving not a trace behind.'

In the autumn, rapid journeys of inspection followed one another, of which the following is a fortnight's record :-

'August 19.-By the 10 train to Alnwick, to Duke of Northumberland. Wrote all the way from London to Newcastle.

' 20 th. - Up early, and with Lord Percy, to look at the Abbey Mill Weir. Attended meeting of the conservators; after that dragged the river, and then on to Alnmouth.

' 21st.- - To see the artificial hatching place; with post horses in Duke's carriage, to Wentsworth mill, and then to Acklington Weir ; then to Felton, and then back to Alnwick. By train that night to Newcastle.

' 22 nd. - Walked about Newcastle, looked at Fish-market and museum. Then on to Hexham, meeting of conservators. Then to Carlisle.

' $23 r$ r. - Drove all down the Aln. Meeting at Maryport.

'24.th.--Returned to London.'

'26th.-To Chepstow ; saw general conformation of the Wye.

' 27 th. - Caermarthen, then on to Conyd.

' 28th.-Up early and went to falls of Penarth. Then to Nerrcastle Emlyn, and then to Cardigan; met Inspector of Police at Nerrcastle, and ordered a new pass for the fish. 
' 29th.-At Cardigan. Drove on that night to Newport.

' 30 th.-By 5 o'clock morning bus, through Fishguard to Haverfordwest. Took fly there; looked at two weirs on the Cleddy; and also paper-mills; then on to Langwm, and thence to New Milford.

'31st.-To Pembroke, then train back to Chepstow : very pleasant week.'

On his return, he described with sympathy the struggles of the fish to surmount the weirs.

'The migratory Salmonidoe are now on their' road from the sea up the rivers towards the spawning grounds; and should any of my readers happen to be in the neighbourhood of weirs or other obstructions on salmon rivers, they should certainly not lose the opportunity of observing for themselves the game qualities which these poor fish show, in their attempts to get over the natural or artificial barriers placed in their highway. I heard the other day of a languid tourist, who, when gazing through his eye-glass at some tired-out fish-pilgrims continually hurled back at a weir, insulted my scale-bearing friends by calling them "speckled enthusiasts." I should much like to have placed the tourist aforesaid in the foaming water beneath the weir, and then, while watching his efforts to get again on terra firma, it strikes me the fish would in their turn have called him, with justice (for he had a plaid coat on), a "speckled enthusiast." Idle people should not insult salmon; at least, I shall always call them to account if they do.

' I have lately witnessed two scenes, which really made my heart ache. When surveying the Coquet, we came to 
a terrible obstruction, called the Acklington Dam. 'This is a wall built in a curved shape right across the river, and stops the ascending fish, as completely as a barrier placed across the street stops cabs and omnibuses, when the Londoners are out " reforming."

"The dam was nearly dry, except one place in the middle, over which a sheet of water, about as wide as an ordinary house window and about 6 inches in depth, was continually pouring.

'The pool at the foot of this weir was perfectly alive with fish. At my first gaze I was astounded, and I felt the blood tingle in my ears, as I caught sight of the swarm of fish, bull-trout, that were attempting to ascend. In the space of one minute I saw no less than twenty-seren fish make jumps, and in the next minute and a half, I counted thirty fish; some of them were little fellows not five inches long; others, large and full-grown fish, the aristocrats of the river.

'The dam was 11 feet high, and many fish actually jumped nine feet straight into the air. I am certain of this, because I walked, with considerable difficulty, upon the top of the slippery stones of the dam, and with a measuring-tape measured the height, and also the points up to which, I had seen the fish jump.

There is a very deep pool at the point where the waterfall joins the lower level of the river. The fish came out of this pool into the air with the velocity of an arrow; they gave no warning or notice of their intentions, but up they came, and darted out of the surface of the water with a sudden rush, like rockets let loose froun the darkness of the night into the space above. When they first appeared 
in the air, their tails were going with the velocity of a watch-spring just broken, and the whole body, sparkling as though enamelled, was quivering with the exertion.

'They looked as much like flying-fish as ever I saw anything in my life. As they ascended, their tails left off quivering, for these tails were machines made to act on water, and not wings to act on air. Their course was somewhat trajectory in form, but not so much as I should have expected. Not one single fish, alas! did I see get over ; some of them jumped into the body of the waterfall, and were hurled violently back, down into the pool, like the pictures we see of soldiers of old thrown down headlong from the ramparts of a besieged city.

' Other fish would put on more steam, and were in consequence carried by their own impetus right through the sheet of water, dashing themselres with the force of a cricket-ball from a catapult against the solid wall which formed the weir. These also, poor things, fell back into the pool half-stunned, and with cut and bruised noses. While the bigger fish were making these strenuous efforts to ascend, their smaller companions were jumping distances more or less high up into the falling water.

' Many had evidently given it up for a bađ̃ job, and were swimming about with their little black noses projecting ont of the white boiling water, doubtless crying out, "We can't get up, we can't get up. Cruel miller, to put this weir. Mr. Buckland, do what you can for us." "Wait a bit, my dear fish," I said; "the Duke of Northumberland is a kind man, and he is going to make a ladder for you; the plans are nearly settled; and you shall then jump for 
joy, and not for pain. In the meantime read this." So I pinned a large piece of paper on the weir, which read thus :-

" Notice to Salmon and Bull-Trout.

" No road at present over this weir. Go down stream, take the first turn to the right, and you will find good travelling water up stream, and no jumping required.F. T. B." 


\section{CHAPTER X. \\ ABOUT FISH, BEASTS, AND BIRDS : 1868-1869.}

Is January 1868 Frank Buckland collected, in 'terribly cold' weather, and packed in ice on board the 'Celestial Queen,' at St. Katharine's Docks, the first salmon and trout ova shipped to New Zealand. For ten years he continued to collect and export salmon and trout eggs to different colonies of Australasia.

The trout ova sent to Tasmania in 1864 had thriven and multiplied, adapting their habits to the climate of the Antipodes, breeding in July, the winter of those climes, instead of in January. The eggs of these trout were sent from Tasmania to Victoria and New Zealand, and multiplied there. The salinon eggs sent out at the same time were hatched out in Tasmania, and grew to smolts; but it was still debated whether the fish, which now and then were seen leaping in Tasmanian waters, were really salmon.

Now trout, salmon trout, and in some rivers salmon, have been by these means acclimatised in Tasmania, New Zealand, and Australia. In Tasmania, the first of these colonies to which ova were exported, most of the streams on the north, south, and east coasts are already fairly stocked with trout, and others contain sea-trout; but at present the Derwent and its tributaries are the only rivers in Tasmania in which the true salmon is believed to exist. 
On February 6, 1868, a dinner of horse-flesh was given at the Langham Hotel, as an experiment of the value of that article of food, which is said to be now rather extensively used in Paris. The guests were many, scientific and intellectual, but, according to Frank Buckland, the pleasures of the table were social rather than gastronomic, 'A very pleasant party at our end of the table, but the meat simply horrible.'

'February 7.--Very seedy indeed; partly effects of horse, partly of a very bad cold ; felt very queer all day.'

The flavour of the meat, though served in various ways, he described as resembling the aroma of a horse in a perspiration.

'In the middle of the dinner I stood up to watch the countenances of the people eating, and I devoutly wished I had had the talent of a Hogarth to be able to record the various expressions. Instead of "men's beards wagging," there seemed to be a dubious and inquisitive cast spread over the features of most who were present. Many, indeed, reminded me of the attitude of a person about to take a pill and draught; not a rush at the food, but a "one, two, three!" expression about them, coupled not unfrequently by calling in the aid of the olfactory powers, reminding one of the short and doubtful sniff, that a domestic puss not overhungry takes of a bit of bread and butter. The bolder experimenters gulped down the meat, and instantly followed it with a draught of champagne, then came another mouthful, and then, as we say, fiat haustus ut antea.'

The condition of the animals slaughtered may affect the flavour of the meat: on another occasion Frank Buckland and Mr. Bartlett experimented with prime 
steaks of horse and beef, and were unable to distinguish between them; yet few would eat horseflesh willingly. A suggestion was made to the Home Office, by Frank Buckland, that if prisoners were fed on horseflesh the prisons would soon be empty. Tenderness for the criminal class has prevented its adoption.

The following are among the correspondence for the year 1868 :-

' February 15th.-The whelks will soon begin, if they hare not already begun, to deposit their curious egg-masses. The study of these is well worthy of attention. The structure of the transparent membrane is horn-like, and the marvellous manner in which the numerous capsules are joined together, and the young ones packed away inside, is most worthy of notice. It would seem almost to be a modification of a bee-cell adapted for under-water existence. 'There are large quantities of whelks on the grounds of the Herne Bay Oyster Fishery. Last year the whole coast was strewed, after a storm, for a long distance with these whelks' eggs; in some, the young whelks were so far developed that their shells had become hard, and when the capsule became dry the young whelks rattled like shots in a child's rattle. There were from three to six young whelks in each capsule. Each capsule is shaped like a lady's handbag, and has a patulous mouth with no appealance of a valve. The young shells have but two whorls and are exceedingly fragile. Whelks are caught by a mode of fishing called "Trotting." A number of unfortunate common shore-crabs are strung together with a. needle and string run through their backs, so as to make a bunch; these are sunk to the bottom of the sea, and left 
for a while; they are then drawn up, and the whelks which have come to eat the crabs shaken into the boat. A number of these bunches of crabs are laid down, and the trotter rows from one to the other. A great many of these whelks are sold as bait for the North Sea cod fisheries, and they will live a long time in sacks. Young oysters are particularly fond of "sitting down" upon whelk shells. I have several specimens in my museum to show this;" one in which the poor whelk is absolutely smothered with them, like flies on a fly-paper. In another specimen, an oyster has fastened himself on to a whelk, and, I think, "proved the death of him." The poor whelk probably carried the great lazy oyster about on his back, till at last he becane so heavy that he could do so no longer; so he gave it up as a bad job, and died to "spite the oyster." Another oyster has taken board and lodging just inside the shell of a whelk. This uninvited guest must have been a terrible bore to the whelk, for he could neither come in nor go out of his shell to look for his dinner, without passing the bailiff in possession of the door. However, the oyster has not quite har all his own way, for the whelk has made him squeeze himself up as flat as possible, so as not to stop the way entirely. Another oyster has taken up his position on the summit of a whelk, like a flying Mercury on the top of a column. This was a wise oyster. He rode about the bottom of the sea at his ease, and saw the world for nothing.'

'A pril.-I have received a steak of a fine bison bull that was killed by the orders of Lord Wharncliffe, Wortley Hall, Sheffield. The poor bull suffered for his ferocity, and has been turned into beefsteaks. The meat is grand 
eating, with a slight game flavour, a little hard, which, perhaps, was my fault in having it broiled, but many degrees better than " hippocreas" or horse-flesh. I distributed the meat sent me in small portions to various friends: they all agree as to its excellent quality. We should all be mucl pleased that Lord Wharncliffe is cultivating bisons. They will doubtless do well in this country. One hardly hears of a gravel pit or new brick-field being opened up on the London Basin, without discoveries being made of the bones of Bos, something or another, Bos longifrons, Bos primigenius, \&c. England is doubtless a Bos-carrying country, and any new variety of beef will be most acceptable to the public, while the animals themselves would be highly ornamental to parks, and be a change upon the ubiquitous and old-fashioned fallow deer.'

'August.-On returning home late, I found on the dining-room table a jeweller's box, with the jeweller's name prominently on the top, but with the envelope torn off, and the lid on one side; on removing the cotton wool, before reading the note, which accompanied the box, I confess I was a little startled at seeing a scorpion at the bottom, with his tail well over his back, ready for the attack. I shook him out carefully, and then discovered that he was dead. The secret of the box being opened has at last leaked out. It arrived at tea-time when I was not at home. Seeing the gold-lettered jewel label on the top, how could the custom-house officer possibly allow sucli a suspicious parcel to remain unopened till 11 at night? It was therefore unclosed with great ceremony, as far as I can understand, and when scorpio the poisonous - not gold bracelet the beautiful-was discovered, there 
was a scene rivalling that when Blue Beard's wife opened the mystic cupboard. The box, scorpion and all, was flung into the grate with a shriek (luckily there was no fire or I should have lost the specimen), and there remained, till the adventurous butler, "John," who has had a good training under me, picked it up, and placed it on the table where I found it. I am glad the scorpion had been killed before he was packed up, as if he had been alive he might have stung sumebody. As it is, I expect a second scolding from the post-office authorities. Some time since a friend killed (as he thought) a viper, and sent him off to me through the post. The viper during the journey thought proper to come to life again, and managed to get his head out of the parcel. On arriving at London, he was killed a second time, and was really dead when I received him. The scorpion affair was a little better, for he had been slain with a nail run throagh his body, before he was put into the pillar-post at Chatham. This little beast is now before me, he much resembles a very large blackbeetle; his length is one inch and five-eighths, and he weighs twelve grains.

'September 5.-On Friday se'nnight, arriving at Herne Bay, I heard news of an extraordinary fish that had been caught. I at once set to work, and found that it belonged to old Mount, a poor old man who lives at Hampton, near Herne Bay. A dredgerman told me that the fish was up at the railway station, and that it was going off to a man at Margate that night. At last $I$ found Mount, and went directly off to the station. As we were going along, the old man told me the following story: "I was out a-sapping for eels on Swalecliffe rock, when I see'd something paddling about and a-flapping his tail. I thought it was a 
gull at first, so I up's anchor and goes to see what it was, and then I found this 'ere great fish ashore. I tried to get my anchor into his mouth, but he would not open it, so I catches hold of his tail with the bight of a rope, but as soon as I went one way he went t'other. So I jobs him through the head with my boat-hook, and lashes him head and tail to my old boat, to see if I could get him home that way. As I was a-going along, he gets under my boat, and pretty nigh capsized me, vessel and all ; so I says, 'I must have you ashore at once, my friend, and have another strike at ye; for I was most afeard on him, he was such a tremendous great thing, and I had nobody to assist me but nyself. Then I got him into shoal water, and when I struck him on the head, he reared hisself right up, and put his flippers together as much as to say, 'Pray don't strike me.' It was over two hours before that beast died, and then he laid hisself out as straight as an oar. He is not an old-fashioned pig porpoise, he is a regular bottle-nose one. He got in my way, not me in his'n, or I should never have catched him. If the Margate man has not sent the money I'll sell him to you, sir. You shall have him cheap as he's beginning to stink. I was half a mind to dig him into my tater ground."

'When I arrived at the station, there was the deceased monster, sewed up in old sacks, and directed to the man at Margate. I did not like to unpack him, so I loosed the cloth on his head, and saw that he was not too far gone to cast. I then bargained with old Mount, and the purchase-money being paid, changed the label and sent him up as "goods" to Neville, at the Horticultural Gardens. A mould has been now made of him by Neville and my secretary, and 
his skull prepared. I have not had time to make a close examination of my new specimen. $\mathrm{He}$ is, however, between 6 and 7 feet long, and weighs (by railway scales) 1 cwt. 2 qrs. 16 lbs. I believe him to be the dolphin (Delphinus delphis), a male. In his stomach were six large eels, some ouly partially digested. Both the dolphin and old Mount were on the same hunting-grounds, both after eels, only Mount had the best of the sport after all-he was "bobbing for eels" and caught a whale.'

'September 19.-A large tunny from Dawlish arrived at my door in Albany Street on the foot-board of the railway delivery van yesterday morning.

'I at once saw that it was such a gigantic thing that I could not cast it in my kitchen. I therefore took it up to the distillery, where I was allowed to operate ou it in the stable yard. On taking off the covering (an old carpet), I found that it was not an albicore, but a tunny, a magnificent specimen. The only fault was, that it had been a little too long out of the water to be pleasant company. The following are its dimensions:-extreme length, 8 feet 7 inches; greatest circumference, 5 feet 2 inches. It must have weighed between three and four hundredweight.

" "Ubique," who was present, informed me, that he has frequently been present when tunnies have been caught in the Mediterranean, and he considers my fish the largest specimen he ever saw captured. This fish was, I believe, caught entangled in a pilchard net; it had probably come out of its proper latitude in pursuit of pilchards. The tunny is one of the mackerel family; in fact, it is very like an ordinary mackerel magnified. It is very plentiful 
in the Mediterranean, especially along the north coast and the Island of Sicily. The fishery takes place in the months of May and June; this is, I should imagine, most probably the spawning time.

'The flesh is as red as beef, and seems to contain a great deal of blood, and it looks tough; nevertheless, vast quantities are used for the Sicilian markets, and formed the Saltamentum Sardicum of the ancients.

'I hope shortly to be able to finish the cast of this fine fish, and add it to my museum at the Horticultural Gardens, where he will form a fit companion for the sharks and the whale.

"There is an old saying, "that it never rains but it pours." On Wednesday last, September 16, I received my tunny, and a telegram that a thresher shark had been caught at Brighton; a letter to inform me that a shark had been captured at Dover; a letter from Cornwall about a sword-fish which had been brought ashore; also news of a large fish washed ashore at Achill Island, West Ireland, measuring 27 feet long and 12 feet circumference. This, doubtless, was an enormous specimen of the basking shark.'

Frank Buckland aided an inquiry by the Society of Arts 'as to the supply of food for the people,' choosing as his text, 'Oysters, Mussels, and Deep Sea Fishing'; and in Angust attended the British Association at Norwich, and gave a short lecture on the progress of salmon and oyster culture.

Frequent journeys to examine rivers and weirs, and advise on and superintend the construction of fish-passes; lectures at Gloucester, Birmingham, Falmoutl, Leamington, Herne Bay, and Holloway; literary work, and casting 
numerous specimens for his museum; the record of these labours fills his Journal.

- October 24.-Casting the whole day; an immense enjoyment. Finished cock and hen bull-trout, female with eggs, and the big gurnard.'

In December 1868, Frank Buckland was examined as a witness, with Professor Owen, in a notable case. The ship 'Dreadnought' sniled from Colombo for London laden with coffee and insured for $3,000 l$. One afternoon they hooked a fish, which broke the line and a moment after threw several feet of its body out of the water, and was seen with the line attached. It was a sword-fish. At 4 the next morning, the mate awoke the captain and told him the ship had sprung a leak. On returning to Colombo, a nearly round hole was discovered in the ship's bottom, piercing the copper sheathing and planking 3 inches thick. The question was whether the hole was made by the sword-fish. Numerous instances were shown of ships pierced by the sword-fish; sometimes to the depth of 14 . inches; but in all instances hitherto known the sword remained broken off in the hole, and both Professor Owen and Frank Buckland doubted the power of the fish to withdraw its beak. 'The great power of the sword-fish,' Frank Buckland said, 'is in forcing itself ahead; its power is in its tail like the screw of a ship, but the fish could not go astern, it would have but little power in that direction. I think if I had a sword-fish by the beak, he could not go back. I have noticed when handling live salmon that they always try to go forward, not back. Whether a sword-fish could extract its beak from a ship's side would of course depend on the depth that it had penetrated.' 'But,' said 
the counsel, "you never had hold of a live sword-fish by the beak and tried whether you could prevent him from going backwards?' 'No, but I should like to.'

This trial, which was decided on other grounds, gave occasion to a suggestive paper on the uses of the beak of the sword-fish.

'I have received from the Mediterranean two fine specimens of the swords of sword-fish. At Constantinople a large number of these fish were exposed for sale in the public market; as many as thirty sword-fish had been caught in one day in the Sea of Marmora; the specimens in the market weighed between three and five hundredweight. They are good eating; the flesh is firm; the colour between red and yellow, but not quite salmonred. The market price was thirty piastres per "hoke," one hoke being about $2 \frac{3}{4} \mathrm{lb}$. There are 120 piastres to the sovereign. Therefore the price of the fish is 1 s. $9 \frac{1}{2} d$. per English pound weight, rather dear for this kind of fish, I should imagine. The two swords sent me are respectively $22 \frac{1}{2}$ inches and 24 inches in length, about 2 inches in width at the base, and not quite $1 \frac{1}{2}$ at the point. They are like long sharp-pointed paper-knives; in fact, I find they make capital paper-knives for newspapers. I can cut open a leaf of the "Times" with one blow, and I can rap the monkeys' fingers when they come to steal from my writing-desk; so that a sword from a sword-fish, if well mounted, would become a very handsome and useful appendage to the desk of a literary man.

'All the teeth of this beast seem to be concentrated, as it were, in this one huge tooth, and the mouth is exceedingly small. By putting these two facts together, I 
fancy it possible, that the sword-fish lives upon minute soft sea creatures, and that he turns up the sand with his sword to hunt for them. This is the only solution I can at all give for the presence of this curions sword.

' $I$ have since ascertained a point in the construction of this sword which I fancy is confirmatory of this idea. When rapping the fingers of Miss Susey, my monkey, who came to drink the ink (a beverage of which she is particularly fond), I happened to break off about an inch and a half from the tip of the sword. On examining the fracture I discovered two minute holes in the substance of the bone. Experience has taught me, that a small probe is always ready to hand, in the form of a bristle from a hair brush. Passing one of these downwards, I found that there was a cavity, going farther than the length of the bristle, downwards towards the thick end of the sword. How to find ont where the cavity ended was now the difficulty, but I soon hit upon a mode of determining the question. I happened to be smoking at the moment, so, placing the broken end of the sword in my mouth, I blew smoke into the holes at the top of the sword, and was delighted to see it come out at the other end in two volcanolike jets. Thus I ascertained, that these minute perforations extend the whole length of the sword. Besides these two holes, there is also a cavity in the centre of the sivord, the dissection of which I have not yet finished. What, then, is the meaning of their presence? I believe they are cavities which, when the animal was alive, contained nerves. At the lower end of the sword, moreover, I discovered remains of the cellular bone, known to anatomists as the ethmoid bone, and upon which large nerves 
lamify themselves. I fancy that the nerves in the sword must take their origin from the ethmoid bone, and that they are nerves of sensation, which assist the operations of the fish, when he uses his sword to rout up the mud and sand for his food. A somewhat analogous piece of mechanism can be seen in the beak of a common duck. This bird searches for minute creatures in mud, and if the reader will take the trouble to dissect off the skin from the upper beak of a duck, he will find a large white nerve on each side coming out of the skull, just in front of the eye, and ramifying itself on the tip of the bill, so that the bird has, as it were, the tip of a finger on the end of its bill, and by the power of touch can select proper, and reject improper food. In my liumble opinion, nature always economises material to its utmost extent, and every organ in the structure of every animal has its use, if we could but know what that use is. This is the doctrine of Teleology : i.e. the doctrine that every organ is adapted to a special use.'

His private Journal contains the following entry :-

'December 30, 1868. - Last Thursday was my birthday. I am now forty-two years old, and in full health of mind and body. My mind, I feel, is gradually hardening into an adult mind. My business as Fishery Inspector has done this. Not only points of natural history are thought of, but also points of business, conduct of affairs, legislation, \&c. This must be a matter of deep study for me. I must teach myself, as I have had to teacl myself nearly all I know; but, thank God, the Dean gave me a good soil at Oxford, which will grow almost any seed placed in it, and I must now plant a new seed. Those of 
observation have grown into big trees long ago; I must now plant the tree of mental reasoning upon things observed. I am truly thankful for all mercies, because all is the gift of God. There are a diversity of gifts, and I have my gift. I hope, when I have to give in my account, that I shall be like the just man in the Parable of the Talents, and the Great Judge will say, "Well done, thou good and faithful servant." Some stupid positivists think nothing of Him who gave them their commission to work: they develope their own ideas instead. Pray, whence do new ideas come but by the mysterious influence of a God-proceeding Spirit, which gives unto all men severally as He will? I do not aspire to do more than my duty in that station to which it has pleased God to call me, but I want to do it nobly and well.'

In 1869 Frank Buckland sent a selection of exhibits to the Exposition of Fisheries at Havre, and was awarded a Diploma of Honour, in company with the engineer of the French Piscicultural Establishment at Huningue, and the King of Siam.

In the snme year, he received a medal from the Acclimatisation Society of Victoria, 'in token of the great services he had rendered to the cause of acclimatisation ;' and in December a silver claret jug was presented to him by the Provincial Government of Otago, New Zealand, 'as a small acknowledgment of the valuable services kindly rendered by him in January 1868 , in the matter of the first transmission of salmon ova to the Province.'

In November he finished a series of models of salmonladders for the $\Lambda$ merican Fishery Commissioners, and sent 
them to New York, together with five boxes of specimen oysters, and a photograph of his museurn.

The admirable exhibit of the American Commissioners at the Fishery Exhibition of 1883 , showed what careful attention the Government of the United States pays to the Science of Pisciculture, care which our own Government would do well to emulate.

Frank Buckland received but little aid in his lifetime in the formation of the inuseum, which he has bequeathed to the nation; and it is lamentable to see, from neglect of proper housing, the rain dripping in at every storm upon the casts on which he bestowed such labour and loving care.

The report of 1869 contains a list of ninety rivers examined by himself or his colleague, Mr. Walpole, over which fish-passes existed; but of these only twenty-eight were effective, forty-eight were useless from improper construction or position, and fourteen were but partially successful. All these were carefully reported on, and remedies contrived and suggested.

This report contains a treatise on the construction of fish-passes applicable to different forms of weirs, well worth the attention of conservators of salmon rivers. 'As men and air-breathing animals pass over water by means of a bridge constructed in the air, so,' he writes, 'Salmonida, who breathe in water, require a bridge of water to pass over the obstructions situated in air, and it is to the construction of these water bridges that we must principally direct our attention; they come into play under circumstances, when the distance which might be overcome by a jump or a spring on the part of the fish is too great.' 
So the ever-varying problem was, with sloping boards, or piled-np boulders, or side-long channels, to break the current's force, or form successive porls, from one to another of which the fish might leap, and scale the weir.

No toil was spared in contriving successful fish-passes ; he waded the streams, walked the slippery edges of the weirs, with many a fall into the water, or knelt in the stream up to his chest to test the force of the current. He felt rewarded when he saw the fish leap from pool to pool and over the weir, as if it were their natural channel.

In 1869 he again, visited Bishop Wilberforce at Lavington. 'The Bishop received me at the door with the greatest kindness and hospitality. Great chaff at breakfast. Put on my water-dress and fished the Bishop's stream both up and down dnring a tremendous storm of wind and rain; present two young Wilberforces, charming young fellows. The Bishop came out to see me working, and also the ladies.'

There were also visits to Blenheim. 'With the Duke of' Marlborough round the private gardens, and fixed on a place by the waterfall where we should set to work to cultivate the fish ;' and again, later, to prescribe for the fish found to be dying in the ponds, and to fresh stock the ponds with 2,000 young fish.

To Windsor many visits were paid in this and previous years, where the Great Lake trout he had placed in the lakes had prospered. 'Dragged the Obelisk Lake. The first haul at upper end got thirteen fish, the second hanl three fish, the largest about $3 \mathrm{lbs}$, none under $1 \mathrm{lb}$. 'The Prince much pleased.'

'To Windsor; dragged the pond again; canght five 
splendid fish, largest about $3 \mathrm{lbs}$; got a good lot of eggs from her, enough to make a show in five boxes. This makes altogether twenty-one Great Lake trout in three hauls.'

Prince Christian, the ranger of Windsor Park, continued to take a lively interest in his pursuits.

' February 6.-To Zoological Gardens with Prince Christian and the Duke of Schleswig-Holstein. Bartlett did the honours. I recommended certain deer and birds for the royal parks.'

' $9 t h$.-Prince Christian and the Duke of SchleswigHolstein came to my museum. They were there two hours; explained everything to them, and they were much pleased. Lee showed circulation of the salmon's blood under the microscope. Rolfe brought down some of his painted fish.'

Many foreign professors and pisciculturists also visited him, and were taken over his museum. He entertained other notabilities.

'February 25, 1869.-With Lee to see the new giantess and the Siamese Twins.

' March 3.-Gave party to the Siamese Twins and Miss Swan the giantess. The Siamese highly intelligent people and seemed much pleased with their visit.

'April 4.--Lee asked me to see the giantess and Siamese Twins; found them looking very seedy and unwell.

' 5 th.-Called on the giantess and Siamese Twins; found them better.'

His opinion was now sought on all Bills relating to his special subjects. 
In 1862 a Scotch Fishery Act had been passed, under which Mr. Archibald Young had been appointed Commissioner of Scotch Salmon Fisheries. This Act was amended in 1868. Frank Buckland was consulted by the Home Office, and by others interested in the Scotch Fisheries, both as to the passing and the carrying out of the new Act.

In 1869 he gave evidence before a Committee of the House of Commons to consider the amendment of the English Fisheries law. 'A tremendous pull; kept my brain as steady as I could, and, thank heaven, answered very straight.' The Committee sat again in 1870, and their report resulted in an amendment Act of that year.

Another Bill, for the preservation of sea-birds, was framed in great measure through his influence. All living things aquatic seemed to have his special sympathy, and the purpeseless destruction of sea-birds, for the mere pleasure of killing, moved his indignation.

A public meeting, held on March 10, 1869, to enlist popular sympathy, was chiefly organised by him. The Duke of Northumberland, Mr. C. Sykes, and many others took interest in this Bill, which after a good deal of discussion was passed, and proved a precursor of others of a like character for the protection of land-birds, and many a bird on sea and land will owe their lives to him.

This year a fresh edition of Dean Buckland's 'Bridgewater Treatise' was brought out, prefaced with a biographical sketch, written, like so much of his literary work, in the train, while journeying to inspect some fishery.

'September 6, 1869.--By morning train to York; 
wrote the Dean's life in the train all the way; finished it just as we got to York.'

In October 1869, when the Serpentine water of Hyde Park was cleaned out, Frank Buckland superintended the transfer of the fish from the Serpentine to the Round Pond in Kensington Gardens, a novel day's fishing. 'On arriving at the Serpentine, everything and everybody was ready for work. An old fisherman from Hammersmith hud been engraged, with his nets, which were worked from one of the ordinary row-boats of the Serpentine. It is very extraordinary how a London mob finds out when anything is going on. When we first arrived at the place of meeting, there were very few people present, and we made our first haul on to the bank; but by the time we had got the net on shore, so many people had assembled, and they pushed down the bank so heavily on us, that it was almost impossible to do any work at all. The first sweep of the net brought to shore an enormous shoal of sticklebacks and a few small roach. As the net came nearer to the land the sticklebacks began to dance into the air and over the net, glittering in the sun like a shower of silver spangles. The crowd hailed our first haul with a shout of derision, mixed with groans from the small boys, who had come with their pickle bottles, worsted threads, and worms to enjoy their usual morning's fishing. These little wretches were exceedingly indignant at our proceedings. "Jimmy," said a little urchin to his fellow-angler, "we'd better go home again, the gents is killing all the tittlers." ' 1 Three water-carts were brought down, and as the fish were taken out of the net they were transferred in buckets to the carts. 'The day's work was

1 Log Book of a Fisherman and Zoologist, p. 151 
not without incident. The old fisherman was nearly engulphed in the mud of the Serpentine, some five or six feet deep ; 'at every step he took he went farther in, floundering about like a great hippopotamus. Two or three joined hands with me, and, advancing into the mud at the end of a chain, I caught hold of the old man's hand, and with a "one, two three and away!" we gave a good pull at him, and he came suddenly out of the mud with a "flop" like a cork out of a wine-bottle.' A water-cart upset in the Round Pond, sending one of the party clean under water. He came up in a second blowing like a grampus, but not much hurt. They worked till after dark, thoronghly wet through. The total result was eleven water-carts full of living fish ; this, averaging each cart-load at 500 fish little and big, would make over 5,000 fish. The great majority of these fish were little roach from two to four inches long; with, perhaps, 200 or 300 large roach, the largest weighing 2 lbs. There were also some Prussian and Crucian carp and tench. One eel was caught, and but one perch, and he was a cripple, for his upper jaw was rounded into a knob like an apple, and his deformed face looked like a pantomime mask. The largest fish caught were bream ; the biggest weighing $5 \frac{1}{2} \mathrm{lbs}$. Four very fat and red gold fish, three large bleak, and one big gudgeon completed the list, with one little trout, the sole survivor of a family of little "Great Lake trout" put into the Serpentine two years before.

The habits of animals, of which Frank Buckland was ever observant, were constantly discussed in 'Land and Water.' One question mooted at this time was whether deer in a park, although clever enough to know the difference between the fowling-piece and the rifle when 
in the keeper's hands, had sufficient thinking power to look up into a tree when their enemy is concealed therein.

'The position of the eye in animals,' Frank Buckland wrote, 'is a subject exceedingly interesting and well worthy of consideration. 'The eyes of the ox, horse, sheep, deer, \&c., are placed in the side of the head, for the simple reason that they gain their food by cropping the grass as they go along, and that they may be enabled to see their enemies, which for the most part are ground-living quadrupeds like themselves, and would attack them on the same level on which they themselves stand. I do not think the deer depends much on its power of vision for safety. Nature always balances her powers, at the same time giving the predominance of development to one particular sense. Thus the eagle depends upon his telescopic eye to find his food; while the mole has very small eyes, but very sensitive organs of smell. The deer trusts more to his senses of smell and hearing than he does to sight. Witness the beautiful ears of the animal, always in motion when danger is suspected; these ears are active sentinels, awake to the slightest sound, while the nostrils test the flavour of the wind as it passes; so that if the enemy were near, the deer would ascertain his presence either by the sense of sound or smell sooner than he would by sight. When watching the deer feeding in Windsor Park, I hare observed that their eyes are so placed in their head, as to command a certain circle of pasture in front of them. Imagine the light of a bullseye thrown on a parement, and you will have an illustration of what I mean. When the deer either lifts his head or lies down, his focus of rision remains the same; and in the ordinary course I think a 
deer seldom, if ever, looks above him, because (except when the sportsman perches limself in a tree) there is nothing particular to see; therefore if a man were concealed in a tree, the deer would probably pass underneath without finding him out. It is not the deer alone that leave people sitting in trees undisturbed; for have we not seen pictures innumerable of King Charles II., with his gold crown on his head, literally "up a tree," while the soldiers are gaping about at the foot of the tree, looking in every direction but the right? Soldiers, we know, are told to look "Eyes right," "Eyes front"; but there is no word of command, "Eyes upwards."

'In order to throw some light on the question of deer looking upwards, I have been making an anatomical examination of the head of a deer from Richmond Park. The anatomical structure and condition of the parts about the head lead me to the same conclusions. In the head we find three sentinels, which are given to the animal to warn it of danger from its enemies: these sentinels are the nose, the eye, and the ear. The question now arises, which is the most active of these sentinels? The ear is a wonderful acoustic trumpet six inches long, and nearly four wide; the great outspread sound-attracting apparatus terminates in a tube about the size of a cedar pencil, which conveys the sound to a marvellous arrangement of bones in the internal ear. 'There can, therefore, be no doubt but that the deer depends very much upon his sense of hearing to warn him of his enemy. We next come to the eye. Although lustrous and beautifully set in the head, I do not consider the eye to approach either to the ear or nose in its capacity of monitor 
of approaching mischief. The pupil, instend of being round as in the human subject, is more or less elliptical; in the dead animal it is simply a broad slit; bence I conclude it is more of a nocturnal than a diurnal eye. The eye in itself is very small, and only weighed one ounce; the lens is exceedingly transparent and crystalline, and the retina painted a beautiful green colour, not unlike that of the seamouse; the optic nerve is about the size of a large wheatstraw. Compared to the optic nerves of some fish, or those of the lion, this wonderful self-acting telegraph is in a comparatively undeveloped state. The eye itself is fixed deep into the orbit; the upper lid is considerably larger than the lower ; there is a pent-house of long and stiff eyelashes, extending the whole length of the upper lid; the eyelashes on the lower lid are comparatively undeveloped; the portion of the skull immediately over the eye forms a kind of flat table, which also projects over the eye itself. Upon its edge are placed several long and outspreading hairs forming the eyebrow. From the general appearance of the eye and its structure, I come to the conclusion that it is exceedingly difficult for deer to look upwards; so the facts observed by sportsmen, that deer do not look upwards, are fully accounted for by the anatomical structure of the beast. We now come to the nose. The nostril itself will admit the top of the forefinger easily. The bone which covers the nasal organ is exceedingly thin. Upon taking it off I find a most wonderful apparatus for enabling the deer to smell. It consists of two pear-shaped bones, the structure of which is like the thinnest film of wax. Upon these bones the delicate nerves of smell are outspread, so as to become cognisant of 
the slightest scent which may be wafted by the air. I at once make bold to state that we human beings cannot possibly have any notion of the acute power of smell possessed by the deer. It is simply impossible that we can have, because the structure of our nose is far less complicated and developed than in the deer. Perhaps this is lucky in these days, when pollutions and unpleasant odours of all kinds are met at every turn. I place, therefore, the organs of sense in the deer's head in the following order of development and use to their owner:-1. The nose. 2. The ear. 3. The eye. These facts may be useful to deer-stalkers, who, if desirous to approach a suspicious deer, should, (1), run the chances of the deer "seeing" them rather than, (2), "hearing" them. Above all, they should avoid the deer, (3), getting notice of their presence by the organ of smell.'

The domestic circle of pets in Albany Street was always maintained. In a large cage by the fire, or, if invalided, sitting in the fender and warming their hands at the blaze, lived a succession of monkeys: The Hag, Jenny, Tiny, Carroty Jane, and Little Jack, whose histories have successively been told. Woe to the coat-tails or flounces which approached too near the cage; and when play-time came and the monkeys were let loose, and chased each other over book-case, table, and mantel-piece, great was the scrimmage! A dynasty of suricates, Jemmy the first, second, and third, cantered about the floor, or sat up and begged for food. Their rat-like portraiture will be found in 'Notes and Jottings.' 1 Sometimes a Mongoose, sometimes a Galego, entered the family, and often a sick

1 Notes and Jottings from Animal Lifo, p. 24. 
Marmozet, or some wilder creature, was sent from the 'Moological Gardens, to be nursed into health. The pets had not lost their inconvenient faculty of straying, causing sorrowful entries in the Journal, such as, 'The Galego got loose; great low with people at No. 49 about it, the beast having broken so many ormaments.'

For some time a magnificent dog, Arslan, a Turkish wolf-hound, adorned the household. Gentle and obedient, even to John the small page, Arslan had one weakness-he could not abide small dogs; one nip, one shake, and the small dog was lifeless. He was nearly broken of this habit, when one day he strayed into a neighbouring garden, where, at an open window, sat a lady with her lapdog in her lap: one bound, one shake, and the lap-dog. was no more, the lady in hysterics, expecting momentarily to be herself devoured. John fetched away the monster; but the lady would not be appeased. Arslan was sent to the guard-ship on the Herne Bay oyster-beds, under sentence of transportation for life. 


\section{CHAPTER XI.}

SCOTCH FISHERIES, AND CORRESPONDENCE : 1870-1872.

Is 1870, considering that the short space of eight years only had been accorded to the protection of Salmonidce, the multiplication of these fish had, according to the report for this year', been very striking. "The United Kingdom,' the report continues, ' undoubtedly stands preeminent among European States in the progress of salmon culture; and it is to our laws that France, Prussia, Sweden, Norway, and even Canada and the United States, have looked, and will look, for a model of legislation based upon experience and accurate scientific knowledge.'

The still more valuable fisheries of Scotland had never been neglected like those of England and Ireland; but in proportion to their value did they merit care, and.as a result of the Parliamentary inquiry of 1869 , to which Frank Buckland contributed his experience, an inquiry was directed by the Home Office into the effect of the Acts of 1862 and 1868 on the Scotch fisheries, and Frank Buckland and Mr. Archibald Young were appointed to conduct the inquiry.

The months of May, August, and September in this year were spent in the examination of the Scotch fisheries, and in the following year a report upon them was presented, the result of much hard work, elaborate written 
inquiries, and careful personal inspection of forty-six Scotch rivers. The benefits of the recent legislation were clear, but various improvements were suggested.

With regard to the cultivation of English rivers, Frank Buckland saw clearly, that the seemingly conflicting interests which, selfishly pursued, had ruined the salmon fisheries, could be reconciled without injury to any; and he strove unceasingly, and with no little success, to unite all classes in a common belief, to him plain as an axiom, that each and all were interested in the preservation of salmon.

The destruction of young salmon, he urged in his report of 1870 , not only exposed the offenders to penalties, but by wilfully destroying the fry, when in an undeveloped state and unsaleable, they were seriously injuring their own pockets; 'it is as foolish an act as slaughtering and throwing away chickens with their feathers first appearing, instead of allowing them to grow into poultry worth several shillings a couple.'

'Millowners who refuse passage for the fish to the higher waters should recollect that, unless fish are bred, they cannot be caught; and that, if a just proportion of fish are let up during the proper fishing season, the upper people will take greater care to preserve them during the spawning time.

'I do not suppose the miller would have any objection to the mill wheel being protected by a grating from sucking in the descending salmon, as it would not interfere with the action of his wheel, and the lives of many kelts would be saved, which would probably reappear as very heavy salmon at a future time.' 
As to the ever-varying problem of fish-passes, his advice was characteristic: "There are but three possible ways by which the passage of a weir may be effected by the fish; first, over the weir ; second, through the weir ; and third, round the weir. In contriving or altering a pass, it will be found to be a useful plan for the observer to imagine himself to be a salmon, and consider which of these three ways would be best for him to adopt. The natural road for the fish to take is over the weir, and it is for this reason that we see the fish jumping at it; but it must not be forgotten, that, if proper means be used, we can induce the fish to adopt almost any other road we think fit, provided always we place structures built in accordance with their powers of locomotion and the dictates of their instincts.'

And thoroughly did he carry out this principle, becoming as an inspector almost amphibious; wading the pools below the weirs, feeling the force and direction of the current, and striving, so far as is possible to man, to enter into the feelings of a salmon. No wonder, then, when it was publicly stated, that in his evidence before the House of Commons, he had leaned rather to the interests of the millers than to the interests of the salmon fisheries, he protested that his statements had either been misconstrued or not understood. 'Having placed myself as a shield over the salmon interests, I have, as is the fate of shields, received most of the arrows.'

In that evidence his ideas as to the construction and position of salmon-ladders were fully detailed. The models then exhibited are to be seen in his nuseum. Since he had given his evidence in August 1869, seven weirs had, 
within his own experience, been successfully made passable for fish, by one or other of the plans he had suggested; and nearly fifty passes, most, if not all of which were working efficiently, had been erected since he and Mr. Walpole had held office, and several others had been greatly improved.

Against river pollutions he continued to lift up his voice, telling the people of Gloucester, that the Chinese, who used everything in the way of manure, called us barbarians, perhaps because we poured our sewage into the rivers. A calculation had been made, that the utilisation of our sewage would produce four hundred and five million loaves of bread, enough to nourish five millions of people for a year. Thousands a year are paid for guano from the South Sea Islands, while we waste what we have at our own doors. 'Take the pollutions from the river, where they are doing harm, and place them on the land, where they would be doing good.'

Returning from the North, after commencing the Scotch Inquiry, Frank Buckland wrote his 'Impressions of Scotland.'

' $I$ always write in the railway, and long habit has enabled me to do this with great facility. I am now on my road south, after much hard work examining rivers on the east coast of Scotland with my co-commissioner, Mr. Archibald Young. We have just passed Berwick, and the engine has got up her running (and splendid running it is) for Newcastle. I shall therefore pass away the time by putting down on paper some of my impressions of Scotland before they are dulled by the racket of London life and business.

'I am exceedingly pleased with Scotland and the Scots. 
The people are kind-hearted, most hospitable, and, above all, highly intelligent; everybody seems to be educated. In all the towns and villages I visited, regularly every morning the streets were crowded with children going to school at 9 o'clock, not creeping along according to the old adage-

The fatal morn arrives, and 0 !

The weeping youtl to school must go-

but stepping along with an active and light gait, as though learning was worth having. At Dumfries, I especially noticed the door of an infant school. There was a regular swarm of little urchins playing about until the clock struck, and in they went like bees into a hive. Few, if any, of these little things had shoes and stockings. They were all exceedingly cleanly dressed, and their hair nicely brushed and oiled. Girls seemed to get their share of education as well as the boys. I went by an afternoon train from Perth to Dundee to examine the fish-market there. At every station along the road, one, two, or three boys and girls got out with their bag or strap full of books. They were returning from the schools at Perth. They went in by themselves in the morning and came out at night, and this every working day in the year.

' Few of the children in the smaller towns and villages wear shoes and stockings. An excellent custom; it saves expense, and makes them healthy. The more you walk upon shoe leather the thinner it gets, the more you walk upon human leather the thicker it gets. I examined the soles of the feet of some fisher girls who were going out to collect mussels at Finhorn; the skin was as thick and as hard as the foot of an elephant. 
'I saw very few kilts - in more than one month only nine-for I counted them. Why are kilts not worn in Scotland? At Nairn they told me, that, if you saw a man in a kilt in Scotland, you might be quite sure he was an Englishman. About Peterhead, the peasants had peculiar wrinkles like crows' feet round their eyes, which they kept partially shut, after the manner of Esquimaux in the pictures. A lady told me that these features were caused by the people, for generation atter generation, being obliged, by the bleak climate and exposure, to pucker up their eyes, to keep out the snow in winter and the dust in summer. Here, then, is a crow's (foot) to pick for Mr. Darwin, a case of cause and effect.

'We drove from Peterhead to Banff, a terrible dreary and open place, nothing to look at but the rooks-they call them crows in Scotland-and the peewits. I thought of plover's' eggs on Epsom race-course. There are so many peewits, that I do not think the Scots know how good plovers' eggs are, and that they are worth threepence each in London. I did not tell anybody of this fact, or the poor Scotch plovers would not thank me for my kindness. Hens' eggs used formerly to be very cheap in Scotland; an old lady told me that she used to give threepence a dozen for them; when her mother, who was English, came to the country, hens' eggs were one penny per dozen; she thought this too little, so she gave the "wife" three half-pence, and her husband scolded her for her extravagance. This was at Nairn : it happened to be market-day when we reached Nairn, and about 5 o'clock in the evening. There was a crowd of women selling dried haddocks; a great proportion of the diet of the 
Scotch people seems to be Finnon haddies; at least it was my lot to have haddocks in some shape or form for breakfast, and generally also for lunch and dinner, every day whilst I was in Scotland. There must be enormous numbers of these fish in the sea off the east coast of Scotland, and the mussel scalps are in consequence of very great value to the fishermen, who preserve them most carefully.

'The fishermen of Nairn are of a peculiar class, like the fishermen of the Claddaugh in Galway; they keep entirely to themselves, and they all have what they call "Tee names," and this Tee name is affixed to their proper name: as John Main (Daish); John Jamieson (Joe); Robert Main (Cogs); James Main (Collie); William Main (Sailor); David Main (Sergeant); Alexander Main (Skipper); John Main (Downie); Hugh Main (Buckie); Robert Main (William's son).

'All the members of the same family have the same Tee name. In one fishing boat there were no less than seven men every one of whom was a "David Main," hence the necessity of Tee names, to distinguish one person from the other.

'I suddenly came upon about twenty or thirty old fishwives; they were sitting round a corner on the sand warming themselves, and waiting for the boats, which $I$. could see in the distance, to come ashore with haddocks from Cromarty Bay. They were all knitting and al talking; my appearance made them suddenly silent: however, we soon made friends. I told them I wanted a specimen of a Scotch fish-wife for my museum; "Who will come?" said I. "I will," "I will," said all of them jumping up in a body. I was frightened at so many offers from so many fair ladies, and bolted like a shot. They all rushed 
after me shouting and holloing, and the oldest and ugliest very nearly caught me. But I was too quick, so she threw her fish creel after me, with a wild hooroo.'

On April 19, 1870, news arrived of the capture of a salmon at Gravesend. 'Went directly and called upon Mr. $\mathrm{W}$ - , who was very kind and civil, and let me have the salmon for $2 l .6 s .0 d$. The people thought it was a dead child I was carrying through the streets. Took the salmon to the Athenæum smoking-room; wrote a letter to the "Times" about him.

"20th.-To Windsor with the salmon. Down the Thames in steamboat of Board of Conservators. Called upon Prince Christian at Frogmore, and showed him the salmon.

'21st.-Sent salmon off to the Museum. Neville tells me an enormous number of people came to see the salmon. ' $23 r d$. - Cast the Thames salmon five times. Took one of the casts down to the Royal Society.

' 29th.-Sir R. Murchison's soirée. Took down cast of group of lizards and puff adder, and the Thames salmon; all much admired.'

The Museum continued to occupy both thought and labour.

'June 20.-Cast big $70 \mathrm{lb}$. salmon; took me from 10 to 3 to do it.' This is the largest salmon in the Museum.

' July 16.-Took cab-load of things down to Museum ; worked at Museum from 11 to 8 ; very tired.

' July 20.-Took another lot of things to the Museum: worked there very hard, nearly all day: place getting into a little order.

' $23 r$ d.-Took down a cab-load of things to the Museum ; 
worked very hard putting up casts. Prince Buonaparte there. Museum is now pretty fair and straight.'

One summer day in this July, when making new arrangements for the trout-breeding establishment in Windsor Great Park, Frank Buckland observed the ground, about twenty yards from where he was standing, in motion. The water from the hatching troughs runs down a ditch, and it was on one side of this ditch that the earth was moving. ' I at once dropped on my knees,' he says. ' I perceived that a mole was looking for his luncheon, and not being able to dig through the hardened earth of the Park, was trying his luck along the softer ground by the side of the ditch. Having taken a good survey of the place, I made a circuit, and crawled on hands and knees to the top of the bank opposite Mr. Mole. He must have heard me coming, for he at once struck off work. In about a minute he began again, and I could just see his dark fur among the green sward; taking a good aim, I jumped from the bank right in front of him. Never yet was a mole so surprised; he wheeled about at once, and began to sink into the earth like a hot knife into a pat of butter. Nature has given a mole a tail-I wonder if he ever wags it. Turning quickly, I was just in time to catch hold of his tail, and then came a game of pull mole, pull inspector. The little rascal fought hard for liberty, and putting out his great broad spade-like fore-paws, stuck as tight in his hole, as an oak trenail in a ship's plank. I had then to pass a stick down under him and lever him out. When I held him up by his tail he tried to bite, but he did not utter any noise or cry, from which I conclude that the mole has no cry. If he had, he surely would have piped his 
whistle when in distress. The next thing to do was to secure the prisoner; so I tied a bit of official red tape round his leg, and looked about for something in which to carry him home. A pocket-liandkerchief he would soon have scratched and eaten into holes; so I emptied the cigars out of my big leathern cigar-case, and for the precious weeds substituted talpes vulgaris. After he had got his wind, Mr. Mole became very lively, and kicked up a fine rumpus in the cigar-case, but I got him safe to the house of my friend Mr. Menzies. We then paraded him on the lawn, and he tried very hard to dig himself into the earth, and succeeded in making a tunnel or two, but the red tape on his leg went into the hole as fast as he did, and showed us his whereabouts. I borrowed a biscuit tin, in which I carried my prisoner up to town, and in the train had plenty of time to make a careful examination of his habits and peculiarities. In the first place, he is tremendously strong. The limbs, which answer to hands in the human subject, are literally earth paddles. They are worked by an enormous mass of muscles; in fact, I was reminded of the pectoral muscles of a bird, which work the wings with such ease and velocity. The digging paws of a mole may indeed be said to be wings, only that they fly through stiff earth, not elastic air. The snout of the mole is very long and tapered; the tip of it is of a bright pink colour, and the beast moves it about with the same facility as an elephant moves his proboscis. It is altogether not unlike the nose of a pig, and it is made to do the same work, that is, to rout in the ground, and to dig up food.

'My mole frequently during the railway journey climbed up to the edge of his tin-box, and looked me straight 
in the face, as much as to say, "Who in the name of Herne the Hunter (whom I often meet at the dead of night when out worm-catching in Windsor Forest) are you? Confound my tail! I wish I was like a guinea-pig, and had no tail, and then you could not have caught me. Look you in the face, why not? Can't you see I have as good a pair of eyes as you have? Please observe them; nature has parted my hair all round them so as to form a circle, and when I like I can close up the hairs, so that unobservant people can't find them, and then they insult me and my family by saying, as 'blind as a mole.' Now, Mrr. Inspector, I am glad for one reason you have caught me. If you will allow me the 'Lancet' newspaper, which I see sticking out of your travelling-bag, I will read you a passage: you sue, I do not want spectacles to make out print-Dr. R. L. Lee has published a paper in the Proceedings of the Royal Society on the organs of vision in the mole, in which, after ably describing the anatomy of my optic nerve, he says, "It will thus be seen that the eye of the mole presents us with an instance of an organ which. is rudimentary, not by the retention of foctal characters, or to use a better term, arrest of development, but through disuse, aided perhaps by natural selection.' Now just tell Dr. Lee that it is nothing of the kind, and that my ancestors, who annoyed the 'grand old gandener,' Adam, by digging' up his grass plots in the Garden of Paradise, had just the same-sized eyes, neither larger nor smaller than 1 have. The same great wisdom that gave me 'earth paddles;' a routing nose, and a fur which-look for yourself-cannot be rumpled, but which is smooth, whether I am going forwards or backwards in my burrow, and that made my 
teeth the most beautiful set of insectivorous teeth among animals, also made my eye fit for the work it has to do. I have been designed to prey upon earth-worms; the worms will not come up to the surface to me, so I must go down into the earth to them; for this work my eyes are fitted, and I defy any philosophers in the world to disprove this." "

In September 1870 he went to a penny wax-work show in Scotland. 'An awful place! The advertisement at the door in the street is a wax Abraham as large as life, killing a wax Isaac: you should see Isaac's face! Inside is the Judgment of Solomon; a wax soldier in an old Life Guard's cuirass with a baby in his hand, held by its heel, while he is going to split the haby with a carring knife like a man splits a salmon for kipper : the baby is crying glass tears! Then there is Noah coming out of the Ark; Shem, Ham, and Japhet in Scotch kilts! All the rest of the waxworks consists of murderers, misers, and villains of all kinds, a splendid army of vagabonds, commanded by a wax poet Burns, whose face is like the war gentleman in the barber's shop, and would be better for some rouge.'

Once, about this time, he found even a superfuity of fish.

A milk woman, not far from Albany Street, served out at the door a pennyworth of milk, and in the milk jug the servant girl found a live stickleback swimming about. When the fish, all alive, oh! was shown to the old woman, she turned round to her boy and boxed his ears. 'Jimmy, oh! Jimmy, you lazy rascal,' she said; 'you never strained the water:"

Some time in the same autumn, Frank Buckland added another monkey to his family of pets; but even he could not always compose the jealousies of that happy family. 
'I received,' he says, 'a note to say that a spidermonkey was for sale. The price asked was extravagant as usual, but I eventually obtained it. My new pet was, without exception, the ugliest monkey I ever beheld; he lad been christened by the name of "Nigger"; a most appropriate name, for he was as black as a coal, and about as lazy as I have understood niggers generally are. Nigger had no thumbs, only four fingers, which seemed to act in concert very much like the hooks that we find in the sloth. If, however, he had no thumbs, he had a tail, and the thumbs seemed to have been by nature transferred to the tip of the tail, for the under surface of the tail, for the length of four or five inches, was covered with thin skin of the same character as that which lined the inside of the fingers, the consequence being that his tail was prehensile in the truest sense of the word. I know this from experience, because when Nigger had his tail round my neck it was difficult to release myself from his grasp. Nigger seemed to know he was ugly, and that it was the only point upon which he could claim anybody's consideration; whenever therefore a stranger came in, he made a pitiful face, and stretched out his long skinny arms in a supplicating manner, as much as to say, "I am only poor Nigger. I cannot help being black and ugly; don't be unkind to me."

"When I got home we let him loose, and the first thing he did was to rush to the fire, and sit on the fender wagging his tail, nodding his head, and grimning like one of Christy's minstrels. My two little monkeys Susey and the Hag were exceedingly indignant when Nigger was brought to my house. It was very amusing to watch the Hag's countenance, when she saw the intruder's queer 
antics. They made fearful faces at him, and when let out of their cages, began a system of persecution amusing to lookers-on, but unpleasant for Nigger. At last I found it impossible to preserve peace with the three monkeys, so I did a little bit of dealing in "Black Ivory" as slavedealing was called, and sold poor Nigger. He was carefully packed up and sent to Paddington. When they opened his packing-case at the Zoological Gardens, Bristol, poor Nigger was found dead at the bottom of the box! I never could find out what killed him, but I have a strong idea he was suffocated. Poor beast!'

'December 17, 1870.-My birthday. I am very thankful to God to allow me so much prosperity and happiness on my forty-fuurth birthday, and that I have been enabled to work so well. I trust He may spare me for many more years to go on with my work.'

New problems in fish-culture had to be solved. It was discovered that a considerable export of unclean and unseasonable salmon, although prohibited, took place from Ireland to France. Frank Buckland applied in turn to the police courts in London, and to the custom-houses of London, Bristol, Folkestone, and Dover with but little effect, until, at his instance, an Act was passed, giving to custom-house officers a right of search for unseasonable fish, which stopped the illegal trade. It then appeared that unseasonable fish were also frequently sold in the London market. After a successful prosecution of one offender, the leading fish salesmen came to the inspectors' aid, and voluntarily gave up a considerable amount of unwholesome fish consigned to them for sale.

Another curious difficulty arose from the increase in 
some rivers, especially the Coquet in Northumberland, of bull-trout (Salmo Eriox) to the prejudice and even extermination of the more valuable salmon (Salmo Salar).

'It appear's to me,' he wrote in his report for 1870 , 'that the increase of bull-trout may be attributed to several causes. We men must confess that, if we interfere with the ordinary course of nature, colresponding changes will ensue, without any opinion on the point being requested from the human race. I give an example of this; the increase of wood-pigeons is principally due to the over-preservation of game. Hawks are shot down in order that pheasants may be preserved: the consequence is that, the natural enemy of the wood-pigeon being destroyed, they at once increase, in a ratio which could not take place, if the hawks, the natural check upon their undue increase, were allowed to continue their natural functions of keeping down their numbers. It is useful to take this example which can be seen, because we cannot see what goes on under the water, we can only argue from results. The increase of wood-pigeons is somewhat analogous to the increase of bull-trout: man has interfered with the ordinary balance of nature. We must also remember that a struggle for existence is continually going on among races of animals. Thus the red-legged partridge has gained the ascendency over the common partridge. Again, the old British black rat has died out gradually before the Norway rat, the former being now but rarely found in the British Isles : and the evil may assume even greater dimensions, for fear is entertained that the rabbits introduced into Australia, and now extending themselves into parts of the country not sufficiently populated to keep 
them down, may eventually do serious mischief to the sheep, not only by devouring their food, but by tainting the ground.'

So after an inquiry duly held at Alnwick, it was decided, with the consent of the Home Secretary, to declare war against the bull-trout in the Coquet, in favour of the salmon.

For five years the war was hotly waged; more than 70,000 bull-trout were slain, weighing over 131 tons, while many thousand salmon were bred artificially in the upper waters. But nature declared herself on the side of the bull-trout, which multiplied in spite of the slaughter, while the salmon showed no inclination to return. An army of 50,000 bull-trout swarmed up the river in the fifth year, and ate up all the little salmon; so the allies of the salmon abandoned the contest, and the bull-trout were left in undisputed possession of the territory they bad conquered.

How great is the fecundity of fish is shown by the following table of the number of ova in different species, as found by Frank Buckland's observations :-

\begin{tabular}{|c|c|c|c|c|}
\hline Name & of Fish & & Weight of Fish & No. of Eggs \\
\hline Salmon ${ }^{1}$ & . & & $\begin{array}{l}\text { lbs. ozs. } \\
12\end{array}$ & 10,000 \\
\hline T' out. & . & . & 1 & 1,008 \\
\hline Carp . & - & & $14 \frac{1}{2}$ & 633,350 \\
\hline Perch . & - & 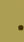 & 3 & 155,620 \\
\hline. & • & & $\frac{1}{2}$ & 20,592 \\
\hline Jack . & . & & 28 & $292,3 \geq 0$ \\
\hline$"$ & . & - & 32 & 595,200 \\
\hline . & . & • & $4 \frac{1}{2}$ & 42,840 \\
\hline Roach . & . & & $\frac{3}{4}$ & $480,+80$ \\
\hline Conger Eel & - & & 28 & $15,191,040$ \\
\hline Smelt. & . & ( & 2 & 36.652 \\
\hline Lump Fish & . & & 2 & 116,640 \\
\hline
\end{tabular}

1 The average number of eggs in a salmon is 850 to each pound weight. 
Diligent care of salmon did not lessen Frank Buckland's interest in curiosities of his own species.

'Among the distinguished visitors to London at this time of the year,' he wrote in May 1871, 'we have now among us a strange party from the other side of the Atlantic. This party consists of Miss Swan the giantess; Christine Millie, or "the Two-headed Nightingale;" and Captain Martin Van Buren Bates the giant.

'It is rather awkward to write a personal description of a lady, particularly as she will probably read what I write ; however, I make bold to say that Miss Swan is the most agreeable, good-looking giantess I ever met; by her side I feel but a pigmy, for she towers far above my head; and an ordinary tall man, say a Life Guardsman, would look like a doll by her side. One never dares ask the age of ladies, nor their height either. Miss Swan is somewhere between seven and eight feet. I cannot say the exact height to an inch, but it is nearer eight than seven; at a guess (I hope Miss S. will forgive me) I should say seven feet six or seren inches is about the mark. Reader, look at the door of your room; Miss Swan has to bend her head considerably to enter an ordinary door; or mark out eight feet on the wall by sticking up a queen's head letter stamp, the top of the young lady's head will be a few inches below this mark. Miss Swan is a native of Nova Scotia, is ladylike in manners and address, and would be a most agreeable neighbour at a dinner-party. In talking to her, however, every now and then her tremendous stature strikes me, and when she stands up she looks like a female Goliath. I should be sorry to have to pay her milliner's bill, for her dress would cover a small haystack, and when she stretches 
out her arm she looks like a statue of Minerva which had walked down from the top of a lofty pinnacle.

'Captain Bates, the giant, is a splendid-looking fellow, very unlike the pictures of the giant in the "fe fa fum; I smell the blood of an Englishman" legend. In fact, the giant is much too well dressed to show off his height. Of all the abominations to appear in in public, nothing in my opinion can equal the black suit, which we English and Americans imagine to be "the thing." If he really wants to look well, let him order a uniform like that of the Life Guards, Royal Horse Guards Blue, or French Cuirassiers. Captain Bates, I understand, has served in the Confederate army; he has been in action, and was wounded three times; why therefore not put on his American uniform?

'Both the giant and the giantess were born in the same year, 1847, so that their age is twenty-four. Captain Bates has three brothers all six feet five to seven inches high. He is about as tall as Miss Swan, and a splendid couple they make when standing side by side. We hear rumours of the god Cupid having been seen as a passenger on board the ocean steamer, that brought this couple from the other side; and also that the Captain has put one of Miss Swan's gloves in his pocket, with which he visited a jeweller's shop, and asked the price of a plain gold ring to fit the fourth finger of the left hand of the lady that wore that glove.

"I must now describe the "Two-headed Nightingale." The Siamese Twins were certainly very wonderful people, but in Christine-Millie we have, I think, something more remarkable. The Siamese Twins are two old gentlemen 
somewhat advanced in years. The "Two-headed Nightingale " is composed of two charming young negress girls, who are united back to back by an indissoluble band. I do not recollect to have seen a more intelligent, everlaughing happy face, than that of Miss Christine. She has dark rolling eyes and jet-black hair, and though her features are those of the daughters of Ham, yet there is a quickness and intelligence about her that shows culture and education.

'Millie is like her sister in face and in her charming manners. They live in perfect concord, and from long habit walk about and even dance, without any appearance of effort or constraint. They are called the "Two-headed Nightingale," because they both sing very well, and the duets they practise show they have good voices, which have been successfully cultivated. Their age is nineteen.'

The same sympathy, which led Frank Buckland to labour for the protection of sea-birds, and to pity and aid the salmon's fruitless leaps, extended to all animals, wild or tame, which seemed to need his help, and his sympathy was not sentimental, but effective.

'I arrived at Newcastle,' he wrote in July 1871, ' at one in the morning of Tuesday last, on my road to the Coquet to examine into certain questions relative to bull-trout. Turning ont before breakfast, I saw a large number of pigs being driven to market past the door of the "Station Hotel." They were, for the most part, pretty fat, and were all marked with three stripes cut into the hair on the left side. The poor brutes were evidently very tired; one by one they kept lagging behind, till an application of the driver's whip made them move sulkily on with a grunt. 
My particular object in writing this article, is to call attention to the great cruelty of not giving these animals some water to drink. These poor thirsty creatures spread themselves across the road as far as the driver's whip would permit them to go, and eagerly sucked and fought for every drop of dirty water they found in the gutters or puddles. If I could have found a pump, and could have arranged a trough, I would certainly have given the driver a drink of beer, to allow me to give the pigs a drink of water.

'After a hasty breakfast, I went to the pig-market, which is close by the hotel; there I found the herd of pigs separated out into pens. I can assure my readers that the study of the faces of these pigs was worthy of the artist, who painted that wonderful pig picture now in the Exbibition of the Royal Academy. The attitude of one of the pigs in the pen was exceedingly human. Piggy was evidently in a state of intense seediness, and so far as I could judge from his countenance-which was, I fancied, paler than usual-was in the condition which we human beings experience after a long and stormy sea voyage, backed up by a dire attack of sea-sickness. Worn out by sheer fatigue, the pig had laid himself down on his side, his legs were extended full length, his head on the ground, and he snored heavily. It was a cold morning, there was no sun, the pig had no cuvering, and every now and then he gave a regular shiver; he was probably dreaming of his comfortable, but now far-off, home, in some Irish cabin, and doubtless his semi-articulated grunts were the dream responses to his mistress's invitation to a drink of butter-milk, or a feed of potatues and barley-meal. A 
theught might possibly have crossed his mind, in a porcine sense at least, "Justice to Ireland" had not been done; he had been petted and fed on the best of food for months past, and all this supposed kindness-he found out too late-was to convert his precious carcase into "rint" for the cabin.

' By the side of this pig was an old sow covered with red hair. The poor old lady could not get a wink of sleep; she kept restlessly shifting her position in every direction, and her bad asthma would not allow her to rest more than a minute or two in any attitude. The squeaks of some little pigs, in a neighbouring pen, seemed also considerably to distract her maternal mind. Every now and then she listened to these squeaks, as though she recognised the voice of the son and heir out of her last fifteen children.

'Upon all the faces of these worn-out pigs there was but one expression, meaning, as plain as a pig's face can speak, water for mercy' sake, give us water! I write this article especially to call the attention of the city authorities of Newcastle to the inhumanity shown to these poor pigs. I have also sent a copy of this letter to the secretary to the Society for the Prevention of Cruelty to Animals.

'On behalf, therefore, of the pigs, I once more make. an appeal for water-a good drink of pure, clean, wholesome water, and not a suck at a dirty street puddle.'

The appeal was not without effect. Travelling soon afterwards in Scotland, he was recognised as the friend of thirsty animals, and learned with pleasure that the Newcastle market was now well supplied with water-troughs.

At the Cat Slow, held at the Crystal Palace in the 
same month, the hard fate of the wild cat drew forth expressions of pity, and an appeal for some mercy.

'There was a great crowd round the Duke of Sutherland's wild cat, caught at Golspie. He was first sent to my house in Albany Street; but the beast was so fierce, that there would have been a "Mutiny of the Nore," both of bipeds and quadrupeds, if I had taken him as a guest; so I was unwillingly obliged to pass him on in a cab to Bartlett of the Zoological, who has put him in excellent condition for the show. Now that the show is over, the wild cat will again retire to private life at the Zoological. At the show he looked very bitter and snarly; he kept his ears flat down, and every now and then smiled a ghastly grin, and showed his white teeth, with a hissing "kuss kuss," as much as to say, "Let me out of this cage but for a minute, you wretched Londoners, and I'll make the lot of you skedaddle. I'm a prisoner now, but I've got good old Scotch blood in my veins, and I would make the bundle of you clear out like frightened sheep, as my ancestors did the Picts hundreds of years ago." I went behind the bar to examine him more closely, and called him, "Puss, Puss, Puss!" I fancied the poor brute smiled, and I fancied also I heard him whisper, "Mr. Buckland, dear sir, I owe to you this delightful afternoon in the Crystal Palace in a cage, instead of spending it in a hollow tree in the far north, with my wife and dear kittens. Kuss kuss you; but never mind, you are a good sort of fellow. I suppose mourir pour la patrie is the correct thing. Uo pray ask the Duke to give his gamekeeper orders not to kill down my friends and relations quite so hard, for we do him more practical service than he thinks; and if we did 
some mischief, there will be plenty of grouse left for the guns on the 12th, and we would all of us rather be shot, and 'die game' at the hands of a sportsman with a breechloader, than be ignominiously trapped, and have our poor legs snapped in half by the cruel iron of a gin set for us, when we are so starved that we might even ask for admission into St. Pancras workhouse; or even let the gentlemen come out and hunt us with terriers and sticks, and we will show them some sport. Ask the Duke to preserve us poor wild cats. Our next-door neighbours, the eagles, told me before I was fool enough to be caught, that the Duke protected them; so perhaps, if you will kindly tell the Duke what I ask you, this charming (oh, how hot it is !) visit to the Crystal Palace may be of use to my fraternity." "

Next to live animals, Frank Buckland loved objects of scientific or curious interest. Every specimen in his own museum had its story and a place in his affections, and he constantly strove to stimulate in others a like taste.

A visit to Canterbury in September 1871 gave occasion to call public attention to the interesting but neglected museum of that city.

'After an inspection of the river Stour, I put off my return to London for a couple of hours in order to examine the Canterbury Museum, about which, by the way, two influential gentlemen of the city, with whom I dined, knew nothing whatever. I shall now attempt to describe its contents, and, at the same time, write what I think ought to be done for the future. Firstly, therefore, the Canterbury Museum contains specimens of very great interest and value, but they sadly want arranging, labelling, and cleaning. Standing just inside the door of the museum, is a 
very fair but small specimen of a stuffed elephant. This poor elephant has been on sentry duty, I should say, for many years. He wears on his back a New Zealand chief's cloak, rather suggestive of a confusion of locality. He ought to have a model howdah on his back to show how the intelligent animal is used in India as a beast of burden. A descriptive label should, moreover, be placed near him, showing the value of elephants, the various localities whence they come, the difference that exists between the Indian and African elephants as shown by the ear and the teeth. The trunk of this poor elephant has a compound comminuted fracture, and straw protrudes from the interior of his trunk in a most artistic manner. The neighbouring cobbler could sew this trunk in five minutes. The weapons from New Zealand, and the South Sea Islands, shields from Australia, etc., are exceedingly good and valuable-they should all be taken down and properly cleaned (not varnished), relabelled, and hung up again according to the countries whence they come.

'Going upstairs, we come to the museum proper. The contents of the cases are in the utmost confusion and disorder. In the first case are some exceedingly fine specimens of fossil elephants' tusks dredged up at Herne Bay, and found in the drift of the Stour valley. These valuable specimens are all piled one over another like logs of wood, and if not soon looked to will fall into dust. The contemplation of these tusks will teach the Canterbury people, that there was something more ancient than even their grand old Cathedral, or even the Romans and Saxons before the Cathedral. The tusks may also cause an inquiring mind to ask, how and when did elephants live at 
Canterbury and Herne Bay; and this may probably lead to the strudy of the local geology, and to the giving an object to daily constitutional walks, while at the same time many lads and lasses may be induced to read the story of our earth, before men appeared on its face, a story much more interesting and thought-coining than the sensational novel rubbish of the present day. In the same case with these elephants' tusks are some casts of toe bones; I at once recognised them as parts of the foot of the megatherium. I looked about for the other bones and soon found them; the pelvis under one of the cases, the femur in one place, the tibia in another, and some more toe bones at the far end of the room. A cast of the armour-plated coat of the glyptodon is leaning up against one of the cases, while the animal's head is several feet away; close to a collection of dried cats, rats, calculi from a horse, an armadillo's skin, wild boars' heads, sharks' teetiz and backbones, the foot of an elephant, the head of a porpoise, and other objects ; all very interesting and instructive if put in their proper places, but now exhibited without order, label, or description.

'The bones of the megatherium should be put together; a clever blacksmith could do it with iron rods and wire, if the order of the bones were pointed out to him; and lo and behold! there would rise up to view the hind quarters of an enormous South American animal, now of course extinct, whose history and habits, thanks to Professor Owen and my father the late Dean of Westminster, are perfectly well known; and a most curious history is that of the megatherium, with his double skull like a fireman's helmet.' 
Thus each case was described and the proper arrangement pointed out. 'I understand,' he continued, ' that the annual number of visitors is fourteen thousand. Surely, then, it is worth while to assist the education of these people, who would not come to the museum at all if they did not wish to learn. Two things are wanted, money and knowledge. A committee should be formed; one gentleman should undertake to catalogue and arrange the birds, another the antiquities, another the shells, another the minerals and fossils; and lectures might be given during the winter months on the contents of the museum.'1

An aquarium, designed to show the life of the denizens of the waters, naturally attracted Frank Buckland's special interest, as an embodiment of his own pursuits. He attended with Professor Owen and spoke at the opening of the Crystal Palace Aquarium in January 1872. He assisted the arrangements for the opening of the Brighton Aquarium in the same year; and in after years he aided the formation of other aquaria at Southport, Manchester, Yarmouth, and Herne Bay. He was anxious, however, that these exhibitions should not be merely places of amusement, but of study and scientific observation.

'The doctrine,' he said, 'that it has been my life-long study to urge, is the application of natural history to practice, and the increase of food for the public. Anemones, soldier crabs, the sensational octopus, barnacles, serpulæ, and other non-edible wretches, are all very interesting and instructive; but besides, I may say above these, I wish to see several problems of vast national importance solved or

' The arrangement of the museum is now considerably improved. 


\section{SCOTCH FISHERIES, AND CORRESPONDENCE 263}

attempted to be solved. In the first place, it is most desirable that some data as to the times and manner of the spawning of turbot, soles, plaice, brill and other commercial sea-fish, should be ascertained, in order that the legislature may have definite data before them, whereon to found laws as to close time for sea-fish, and the prohibition of inshore trawling during the spring months. A turbot of 8 lbs. carries 300,000 eggs ; a sole of $1 \mathrm{lb} .130,000 \mathrm{eggs}$; yet look at the price of turbot and soles; where and how does this immense loss take place? The herring fisheries are of vast importance, yet there is no law as to the mesh of the net, so that joung unsizable fish are sent to market. The time of development of the varions fish in the egg, and the rate of growth in the fry, should be carefully noted. Everybody likes to eat whitebait. What are whitebait? Those on the table often consist of the fry of some six kinds of fish, with occasionally a good dash of sticklebacks. Let ns turn a pint of live whitebait-a marine Pandora's box - into one of the tanks, and see what will happen. We salmon preservers lose thousands of our smolts, which have been hatched out under expensive preservation of the spawning beds. When the little things get into the estuary of the river, and find their way. into the sea, a large number of them disappear from some cause or other. What are those causes? Why is it physiologically necessary for a smolt to go to sea at all? We know the external difference between a smolt and a grilse, but I do not know anybody that has ever seen a young salmon in the intermediate stage, i.e. half smolt, half grilse. May we not, even further, having obtained the requisite knowledge, some day be enabled to fatten our 
grilse as they fatten early chickens for market? Again: how long do the kelts require to transform themselves into clean fish? A live kelt in a tank would be a grand study for all interested in salmon, and perbaps he might tell us some of his family secrets. The salmon fisheries of the United Kingdon are worth a great many hundreds of thousands a year; they are yet capable of vast improvement. We know pretty well what these valuable fish do in the rivers, but we want to know more of their habits in the sea, and if possible extend our protection to them when in the sea. Oyster and mussel culture has of late been much advanced, but there is a point where our knowledge is pulled up short. Prawns are at a very high price, and where is the man who can tell us the details of their breeding? The price of lobsters is also amazing. Yet people eat lobster eggs at dinner parties by the hundredweight every spring; and berried lobsters, with the young plainly perceptible in the eggs, can often be seen on the fishmongers' slabs, waiting their turn for the boiling pot. This will not do; the matter must be looked to; but what are we to do, if we have not knowledge of the habits of the young lobsters? My friend Mr. Lee and myself hatched out a pitful of young lobsters, and pretty little fellows they were, at Reculvers; why not repeat the experiment in an aquarium? The Scotch cod and haddock fisheries want mussels for bait, and the poor people of large cities are fond of mussels, yet our knowledge of the breeding of mussels is of the roughest kind. There are

- many other points which require attention. The Aquarium Company at Sydenham have a great field open to them, if they will convert their tanks, some of them at least, into 
observatories for watching the habits of sea-fish of economic and commercial value. Thus their exhibition will be not only ornamental but practically useful.'

Nor were his anticipations disappointed, when in the following year, at the Brighton Aquarium, he observed, with intense pleasure, the change in the growth of salmon from smolt to grilse.

'There are occasions of supreme felicity; they don't come often. But I confess to the immense delight that I felt when I saw the salmon at the Brighton Aquarium. In the spring of 1873 , my friend the chairman of the Usk Board sent some salmon smolts to the Aquarium. They all died but one; and friends, fishermen, what can you see now? This smolt has become a grilse. It is not a large grilse, not more then ten or twelve inches long, but a pure salmon grilse for all that. He shines like a bar of silver as he swims round his tank, sometimes leisurely, sometimes with the rapidity of a hawk. He is a wonderful and beautiful fish, the first smolt that ever turned himself into a grilse under the ken of us air-breathing mammalia. Naturalists can't live in the water, fish can't live in the air; so we make water cages for our fish, and we observe their wonderful transmutations from one stage of adolescence to another; changes quite as wonderful as the transformation of a dull-coloured, hairy vegetableeating caterpillar, creeping along the ground, into a butterfly, which flies with ease in the air, on wings thinner than silver paper, and ornamented with colours, far more beautiful than anything that can be painted by artists.'

Notwithstanding the almost incessant labour of river 
inspection, and the time engrossed by watching and attending the proceedings of Parliamentaly ccmmittees, and of the legislature, on fishery questions, Frank Buckland's other occupations would have seemed sufficient to fill up a busy life.

Every week the natural history columns of ' Land and Water' were edited, and multifarious questions answered; and frequent articles appeared in that paper, or in the daily press.

'Tired out with the most interesting but everlasting Salmon Bill, now before the committee of the House,' he wrote in May 1872, 'I went the other afternoon to the Royal Academy, as I thought I would try an experiment, how far the painter's art could convey what he really meant, without the interposition of a printed description; so I bought no catalogue, and thoroughly enjoyed examining the pictures, especially as I am teaching myself to paint my fish-casts and like to learn.' And so he proceeded to criticise from a naturalist's point of view, in a most amusing strain, some of the principal animal pictures of the year, winding up with, "Now, my dear' readers, I must stop. I write this from memory in the train, going to Shrewsbury on official duty, and I am nearing this fine old town. If I have offended any artists, I hope they will forgive me; but they really should observe nature; after all, what I have written is only in fun, you know.'

The article was reprinted in the 'Times' from 'Land and Water,' and caused much amusement.

Mr. G. A. Sala wrote 'most heartily and sincerely to congratulate' the writer 'on the very sensible and sug- 
gestive notes on the zoology of the pictures in the Royal Academy.' 'These fifteen years,' he added, 'I have been the art critic of the "Daily Telegraph," and am even now drudging at the canvases in Piccadilly; but I can assure you that your professedly rough and ready critique has been to me a very valuable lesson, and I hope it may be one by which my colleagues in the ungentle art may profit.'

'This,' Frank Buckland noted, ' is one of the greatest compliments I ever received.'

In 1874, some similar notes on the Royal Academy again appeared in 'Land and Water,' which are here reprinted. The truth and force of Millais' painting (Nos. 68, 75) did not escape his notice, nor did the pathos of Mr's. Butler's ' Roll Call' :-

'I have again visited the Royal Academy without a catalogue, and without having read any critiques on the pictures, as I wished to see how far the artists have succeeded in representing scenes, which explain themselves. A picture should not require a printed description to show what is meant. Painting should be a language by itself.

'No. 20. A Heavy Sea breaking on and over rocks, with cormorants sitting and flying. Why not make the cormorants more distinct? The flying gulls not made graceful enough. Can't tell of what species they are. There are plenty of cormorants and gulls at the Zoological, which would have done for models. Gulls or terns, when flying, are most beautiful objects, especially when set off by a black cloud behind them.

'No. 24. The copper vessels are most beautifully painted. 
'No. 26. Fishermen have come ashore with fish. The fish are bad. Surely there are plenty of cod and haddock recently caught to be seen on the fishmongers'slabs. Too much red about the white underside of the skate. Landscape very pretty; looks like the mouth of the Dovey.

'No. 43. A Young Lady with white hair asleep. She looks very bad, and has evidently a great deal on her mind, poor thing! A cold chicken on the table by her side. She can't eat much of it, only a bit of the wing. Claret in glass well painted; the lady has hardly touched it. I suppose they could not get her a cup of tea; ladies are always ready for a cup of tea. If I had been the painter, I should have put a live mouse on the table-cloth, or nibbling at the chicken; it would have given a good idea of great silence and solitude. I feel much for the poor young lady, who, I think, must be a French girl. I wonder what may be the cause of her hair turning white ; it does not look like a natural whiteness.

'No. 50. Fox Cubs. Three heads peeping out of a hollow tree, but I wonder what they are standing upon inside the tree. Foxes' faces, especially cubs, are more difficult to paint than those of babies, the expressions of both are so varied. I never yet saw a fox's head stuffed properly, for the taxidermists generally put in round pupils to the eyes, like the eyes of dogs, not slit-like pupils like those in a cat's eye. Foxes being nocturnal animals, have nocturnal eyes. A wren is on a bough close to the fox cubs; one of the cubs should be looking at the bird. The scene would liave been better if the cubs and vixen had been represented playing outside a regular "earth." 
'No. 57. A Dog attacking a Hedgehog. Not a very plucky dog. His mouth is shut, and it ought to have been open, and his lip should have been bloodstained with the prickles of the hedgehog. He should have been made barking. A dog can't bark with his mouth shut.

'No. 67. Meant for a sleeping baby and mother. The baby is not asleep, only pretending. The lady does not look like its mother, or she would be looking at the baby, and not away from it. She is probably the nurse.

'No. 68. Trees, probably in Scotland; magnificently painted. The idea of a very hot day admirably given, as some black pods are bursting with the heat. On hot days these pods bursting make a very peculiar noise in woods. This picture would have been perfect if a squirrel had been made climbing, with his beautiful brush and knowing little face, up one of the trees, the scene being quite in a squirrel country. It is not too late even now to put in Master "Skug."

"No. 75. Birch Trees on Waggon. Bark and moss on bark very good indeed. Don't quite see where the smoke in the distance comes from. Is it smoke or mist? The birch-wood is probably going to a fern mill, to be cut up to make cotton reels, or possibly furniture for some Londou firms. A girl and a dog are looking on in the distance. No doubt the horses to draw the waggon are just coming up.

'No. 97. People fishing in tidal waters with "Fixed Engines." These are large dip-nets like immense minnownets. The scene is not in England or Wales, or I should have known where it was. It looks like China to me. 
The fishermen probably throw bait, such as dry cod roe, over the net, and when the fish have assembled haul it suddenly. This mode of fishing was formerly adopted in Hampshire in catching atherines-called there "smelts," and a net like it was formerly used to catch salmon below Trew's Wear at Exeter.

'No. 106. A Labourer's wife bringing his children to him, when at work near a big mansion. I don't see that the good woman has brought his dinner. A lady is walking in the grounds of the mansion; she probably wishes to change places with the labourer's wife. This picture tells its own story.

'No. 109. Fish again dubious; no nets in the boat to indicate what the men have been after.

'No. 129. Two very pretty young ladies putting roseleaves and lavender into china vases, to keep the moths out of their sealskin jackets, which they have just put away for the summer. China vases are magnificently painted; also rose leaves and lavender. Pity the picture can't be scented like rose-leaves and lavender.

'No. 130. Bold rock with moss; very true to life. This looks like a scene in Cornwall. Don't see why the young lady is gone to sleep. Somebody should win a pair of gloves.

'No. 142. Foot Guards parading on a snowy day after action; probably a Crimean scene. Anxiety on officer's face well depicted. The horse looks as tired as the officer. The boots of the men have that white appearance of boots when worn in snow. Expressions of wounded soldiers very true to life. A young soldier, who has not been wounded, affords a great contrast to the man with the 
scalp wound, and the one with the shot through his left wrist, and the poor fellow that has just fallen-fainted, or dead-on the ground. The feather in the Doctor's cocked hat is seen in the rear. If I had been the Doctor on this occasion, I should, probably, have been going round with the commanding officer and the serjeant-major, to answer any questions put to me relative to the wounded men, but many of the men badly hit should have been in hospital-not on parade. A very nice picture, true to nature.

'No. 168. An old Monk carrying two rabbits in a woodland park. A dog by his side. The dog seems very long in the body-perhaps monkish dog's were long. Don't see how the old man has caught the rabbits; he has no gun, ferrets, or trap. Possibly they are tithe rabbits.

'No. 181. Red Deer coming round a corner. Very pretty; the artist must have seen this and photographed it in oil colours; he could not have imagined it.

'No. 186. Scotch Cattle. Prettily grouped, but their coats are too clean. The satin glow upon the neck of one cow very pretty. The cattle are looking too many different ways; this has been done probably for effect. On a hot day like this, there would have been lots of flies about the cattle, whereas there are no flies in the picture.

'No. 192. Sir William Fergusson. An exceedingly good and striking portrait. Our great surgeon is evidently about to perform a resection of the left shoulderjoint (see left scapula in preparation bottle). The scene of the picture is ably made known to the spectator, by the first few letters of the words "Operating Room" being visible, and by the slate, with chalk and sponge, on which 
Sir William has just made a diagram to show the stadents the relative situation of the structures, which must be divided in the operation about to take place. The attitude of this most eminent of European surgeons is exceedingly natural; the likeness admirable. This is the proper way to paint an eminent man, not put him in the flowing robes of a Roman senator, like Sir Robert Peel in Westminster Abbey.'

But the artists were too sensitive to relish even such good-humoured home truths; and Frank Buckland would not, willingly, wound any man's feelings; so, although the editor of one of the leading journals urged him to repeat the criticism, offering him his own terms, he refused; he had got, he said, into such hot water with the artists, by telling them the truth, that he dared not repeat the dose.

Another episode of kindliness to man and beast occurred at the end of 1872 .

'About Christmas time 1872, after several hours of hard work, writing my official report at my office, No. 4 Old Palace Yard, I found on turning out that the weather had become bitterly cold, blowing half a gale of wind, with sleet. Running along the not particularly well-lighted pavement, I nearly stumbled against a man standing at the corner of the street by St. Margaret's church; luckily the glitter of metal on his cap caught my eye, and looking at this I saw that it was a brass plate with the word "Blind" engraved on it. The poor man was tapping his stick against the kerb-stone, apparently wanting to cross over the street, so I waited quietly to see what would happen. He had with him a little dog tied to a string; the dog was in the roadway pulling at the string, while lis master kept tapping 
the edge of the pavement, and evidently intently listening for the sound of wheels. At last the man said "Go!" In an instant the little dog ran across the street, pulling with open mouth and extended tongue at the string, like a greyhound in slips. I was pleased to see that the pair of them arrived quite safe at the other side. I at once entered into conversation with the blind man, and, wishing to obtain his history, I told him to call the next evening at my office, as he went to his usual stand.'

And so the story of the blind man, and of Puss the blind man's dog, was told, extending the sympathy Frank Buckland felt for them so widely, that within a few weeks subscriptions for more than forty pounds were received for Puss and her master, which placed them both in comfort instead of privation. 'The subscribers represented kindhearted people of all classes, from noblemen and noble ladies, who sent their sovereigns, to servants, who sent their sixpences, and schoolchildren, who sent their single penny queen's heads.' 


\section{CHAPTER XII.}

THE ZOOLOGICAL GARDENS AND SEAL FISHERIES : 1873-1874.

YEAR after year Frank Buckland continued to watch over the improvement of the English and Welsh rivers, advised on or designed the fish-passes required, and in his annual reports traced the general though varying progress of the salmon fisheries, and recommended such additional legislation as growing experience suggested.

Frank Buckland was no mere enthusiast; that his unresting energy was balanced by sound practical judgment, is shown by the statement, in his report of 1871 , of the principles of action which had gained success in his official duties.

'The element of fighting is not, in the present days of enlightenment, at all called for; an injudicious zeal in the cause entrusted to an individual by the public, may often damage that cause more than promote it. Salmon do not form the sole food of the people; bread comes before salmon. Water power is much utilised, especially in parts of the country where there are no coal mines, for the purpose of grinding corn into flour : it is also, in the case of manufactories other than corn mills, the source of great riches and employment to many poor people. There is no reason wnatever why both mills, manufactories, and salmon 
should not co-exist and flourish, provided there exists, what is called in common parlance, an element of give and take: i.e. when the wheel, the motive power of the machinery, does not require the water, let the salmon have it; and it should be the duty of the Conservators and Inspectors to see that the water is properly economised for their fish. I feel convinced that persuasion is better than force, and that private interviews and subsequent communications will often succeed in obtaining for the salmon, what no Act of Parliament, in the absence of the Local Executive, could obtain.

'What the public require of me, as a Government officer, is to use my best endeavours to increase the supply of salmon. Long experience has shown me how best to do this in individual cases. Those not actually engaged in the work can know nothing of the details required. Though my writings may sometimes seem opposed to the salmon cause, jet I can assert that what I say and do in this important matter, is founded upon anxious thought, and views of all sides of the question. Facts are the great things to be desired, and these can only be obtained by accurate observation out of doors, and by the dissectingknife and the microscope indoors. The science, for it ought to be elevated to a science, of salmon culture is yet in its infancy. I make it my daily business, to endeavour to deduce from the facts that come before me the general laws of nature, which are higher than the laws of man.'

'It may possibly be remarked,' he wrote again, 'that in these reports $I$ have entered too much into detail ; but salmon cultivation consists of details, and there is hardly any particular or object, however slight and apparently 
unimportant, that is unworthy of attention of those who wish to increase the number of salmon in the waters which are confided to their care."

A Parliamentary Committee sat in 1872 , which led to a salmon-fishery Amendment Act in 1873, carrying out to a great extent the recommendations which had been suggested and discussed in the Inspectors' reports.

Frank Buckland recognised from the first, that the variety of nature could not be strained into uniformity by human law.

The habits of salmon, their breeding time, and periods of migration differed in different rivers, and the legislators of 1861 hoped, but in vain, to induce them to conform to the uniform close time defined by that statute. The idea that preservation could convert a late into an early river was disproved, and the Legislature now wisely fitted the law to the habits of the salmon; 'for the simple reason that salmon refused to take cognisance of the edicts of the law.'

Power, therefore, was given by the Act of 1873 to adjust the dates of the close time, and the mode of netting, to the habits of the fish in particular rivers, and to make local bye-laws according to differing circumstances. The inquiries, which preceded the exercise of this power, gave full employment to the habits of observation, the experience, and the tact possessed by Frank Buckland and his colleague. The doctrine, which Frank Euckland had constantly practised, and had striven by personal exertion and influence to enforce - that the passage of fish might generally be secured without injury to the millers-was now, to his rejoicing, admitted by the Committee of 
THE ZOOLOGICAL GARDENS AND SEAL FISHERIES 277

the House of Commons, and adopted as the basis of legislation.

In a letter to the 'Times' he summarised the effect of the new Act and the progress of fish culture.

'After long experience I am convinced that artificial culture of migrating Salmonidce can never compete with natural cultivation. This consists not in hatching out a few hundred thousand salmon eggs in boxes, but in opening up for the parent fish as many miles of spawning ground as possible. The salmon know their own business much better than we do. During the last few years, fisl culture on a large scale has been gradually and carefully carried out in England and Wales. At one time it was thought that the same form of fish-pass could be adapted to all obstructions to fish: we now know that every weir requires a different form of pass.

'Since the Salmon Act of 1861 was passed, we have discovered that the salmon will not obey the laws which the Legislature enacted; and it has now been found necessary to call the salmon into consultation, and adapt legislation to the habits and instincts of these clever, mysterious, but most valuable creatures. Salmon will not ascend rivers according to Act of Parliament, but will come up just when it pleases them so to do. During the past twelve years, it has been illegal to catch salmon with the net after August, and with the rod after October. The new law takes cognisance of the habits of the fish; and for the future it will be lawful, with the sanction of the Home Office, for the net fishermen in late rivers to catch salmon during certain days in September, and the rods will be allowed to fish during certain days in November. By these means I 
trust many tons of salmon will be sent into the markets, while extra sport will be afforded to anglers. By means of bye-laws, it will henceforth be possible to increase the weekly close time, so as to give the upper proprietors a better share of the fish. To allow the use of a net to catch the sea-trout, that have hitherto escaped through the legal salmon-mesh two inches from knot to knot; to give a play-ground or resting place for the fish, at the mouths of rivers; to preserve kelts that have spawned, and fish that are about to spawn, from fatal wounds from the gaff of the poacher; to preserve down fish and fry from being smashed to pieces by mill-wheels; to regulate the fishing for fish other than salmon during the annual and weekly close time: these form the subjects of bye-laws. But besides, water bailiffs have increased powers to preserve fish from poachers. Eel stages are to be removed from January to June; and, above all, the law now enacts that the sluices in front of mill-wheels are to be kept shut on Sundays, and at all times when the water is not required for milling purposes. The consequence of this will be, that on Sundays, throughout the length and breadth of the land, the water, which for six days has been diverted from the liver to turn the wheel, will by law be sent over the weir; so that the ascending fish will have an extra chance of getting up, while the descending fish will be enabled to get down to the sea, earlier in the spring than they did before.

'This is what I call real fish culture, carried on over many hundred miles of river and mountain-brooks in our orrn country. By careful observation we find out what nature's laws are, and endeavour to obey them; and, if it were not for 
the polluted state of many of our rivers, our salmon produce would almost double in a very few years. Artificial breeding is nevertheless most valuable; first, to increase river or lake trout; secondly, to import or export eggs. I have, since Christmas, received and distributed about 150,000 eggs of great lake-trout from Neufchatel and salmon from the Upper Rhine. I understand the Duke of Sutherland has wisely laid down nearly a million salmon eggs, to change the breed of salmon in the various Sutherlandshire rivers. Lord Exeter has now hatching out American brook-trout and white-fish and American sea-trout, Salmo amethystus, sent over by Sir Edward Thornton. Colonel Goodlake has, at his fishery at Denham, near Uxbridge, a very fine stock of American brook-trout, a very handsome, sporting fish, which bids fair to be naturalised in this country; while the golden tench of Central Europe has already been made almost a common fish by Mr. Higford Burr, of Aldermaston Park, Reading.'

The Act of 1873 also forbade killing the fry of eels, which swarmed up the Severn and Wye in April and May, and had been caught by millions; but the magistrates hesitated to enforce the law, when the question was raised whether elvers, as they were locally called, were really young eels. Frank Buckland went to Gloucester to prove their identity. He produced specimens of the eel in the various stages of its development; pointed out the peculiar formation of the eel's head, the lower jaw fitting over the upper like a close-fitting box; the eye exactly over the junction of the upper and lower jaws; the teeth set upon the roof of the upper jaw, and upon the edge of the lower jaw ; the fin, beginning about the centre of the body, and then ex- 
panding into a beautiful fringe again enlarged at the tail. The eel also is a fish which very often goes from place to place out of water, and nature has provided in a marvellous manner for its living out of water; the gills or breathing organs are covered up by a delicate curtain, which acts as a valve and as a reservoir for water, thus enabling the fish to take in a gill full of water, so to speak, and to keep his gills moist during the time he is out of water, preventing the gills from sticking together and stifling him. An extraordinary fact is that an eel has a heart in his tail, which, when the eel is dying, pulsates at the rate of 95 to the minute. This little heart was said to exist in no other fish; but this, and each other particular named he proved, with the microscope's aid, to exist alike in the elver as in the eel, and their identity was conclusively established.

In June 1873 he turned out into the Thames a large number of young salmon hatched at South Kensington. 'Although I was very sorry to have to turn out my little fish babies that I have so long regarded with affection and interest, watching them from the egg ripen into fishhood, yet it was absolutely necessary, as, in spite of the number I have sent away, my hatching troughs wère getting so full of fry, and the temperature of the water was going up so fast, that they began to die. Moreover, I conld not possibly afford to keep so many fish at my museum, for it must be known that these little fellows are very greedy and expensive to feed. I feed them with red worms collected from the Thames mud. These worms cost $4 s .6 d$. a quart; the price of 'Thames worms, like everything else, has increased considerably. I have therefore made three excur- 
sions to turn out my young fish into the Thames at Staines, Windsor, and Shepperton. These little fry have not the same amount of intelligence as fry found in a wild state. When first turned out, they seemed stupid, and gaped about as though they did not know what to do; nor indeed did they go far away from the place, whereas a wild fry would have bolted in a moment. I hope these little things will soon learn to feed themselves, though it is possible that some time may elapse, before they find out that they are no longer in a glass nursery with Mr. Edon to give them their breakfast, dinner, and supper regularly; nevertheless, they are all out now, and must take their chance. I have done all that parental care can suggest for their welfare. I am well aware that there are persons who will say, that "Buckland has only been putting out his fry to feed the jack and perch." Very likely a large proportion of them will be eaten by the jack and perch, but surely some of them will escape; besides which, it must be recollected that these are learned fish, and have been reared in the Science and Art Department in South Kensington. They ought therefore to have more science and art in their little brains, than the vulgar' little common fish hatched in a gutter and not in a beautiful slate trough.'

Each event at the Zoological Gardens was watched with interest. The strange arrivals there were promptly announced. 'The Zoological Society;' Frank Buckland was wont to say, 'may boast of an illustrious pedigree of more than six centuries.' The first collection of wild animals was made in the Tower of London, and consisted of three leopards, sent to Henry III. by the Emperor Frederick II., 'in token of his regal shield of arms, wherein those 
leopards were pictured.' Six centuries ago, in A.D. $125 \tilde{3}$, the sheriffs of London built a house for 'the king's elephant, the first seen in England.' James I. was fond of baiting lions and bears in the Lion Tower; and animals more or less in number were kept in the Tower of London, till they were transferred to the Society's Gardens in Regent's Park in 1834.

Special interest attached to the birth of Guy Fawkes, the young hippopotamus; and no nurse could be prouder of child, than Frank Buckland of the thriving growth of this prodigious bantling.

'Wednesday last, November 5, 1873, being the first birthday of little Guy Fawkes, the young hippopotamus, I have called at the Zuological Gardens to wish the pretty little fellow "Many happy returns of the day." I chanced to call at his breakfast-time, and was fortunate enough to witness the operation. The water in the bath was as clear as crystal, and I was able to observe everything that went on. The mother laid herself down on her side, turning over like a huge bacon-pig asleep. The young one stood on all fours on the bottom of the tank. He stayed under water from half a minute to a minute and three quarters; he then came to the surface, took a deep inspiration, and sank again as quietly as a frog. It was very interesting to see, with what little splash or noise these gigantic creatures can lift their heads to the surface of the water. After he had finished his breakfast, the keeper enticed Guy Fawkes and his mother out of the water. The little one is as tame, playful and docile as a kitten. We made him out to be about 6 feet 4 inches long, and 2 feet 10 inches high at the shoulders. His 
back is a slaty black colour; but his cheeks, chest, and legs are of a lovely pink salmon colour. We calculated his weight to be nearly 1 ton; and his mother would make and weigh about three little hippos. He eats and sleeps well, and, besides his natural nourishment, his meals consist of chaff, bran, mangold-wurzel, scalded oats, biscuit, and sugar. He is very fond of anything sweet. He has already learned to beg for food; he puts his head out between the bars, opens his mouth, and pricks up his little ears when he wants to beg. The gape of his mouth is about 18 inches; he has already a most lovely set of white teeth, and the tusks begin to project out of his pink gums. His mother is very watchful over him; and if she thinks anyone is about to disturb her child, hisses loudly, like a big snake. Every morning, when it is moist and wet, he and his mother are let out into the bath outside; when it is dry and frosty they are kept in the house, as the frost would crackle and parch their delicate skins. When in his morning bath, he is very playful and plunges about like a porpoise. The pair of hippos sleep on the straw all night, but they spend a great portion of the day in their bath in the house, in a sort of semi-sleep. They float up to breathe apparently without an effort, like corks rising to the surface; when under water they keep their eyes wide open, after the manner of crocodiles. When the mouth of the young one is wide open, it will be seen that the tongue is arched directly upwards, so as to form a compact valve, which prevents the water going down the gullet. The old father, in the next den, talks to his wife and child by means of sonorous gruntings, and they answer him. The father's face is much longer and sharper 
than that of his wife, and his eyes and nose are much more prominent. I have forgotten to men'ion that Guy Fawkes turns out to be a young lady hippo; she is more delicately featured than her father, and is very like her mother in face.'

Many were Frank Buckland's stories of the Zoological Gardens. One was how Obash, the first hippopotamus, once got loose. It was early in the morning, before the Gardens were opened, when a keeper rushed into Mr. Bartlett's house, exclaiming 'Obash is out!' and, sure enough, there came Obash down the long walk, his huge mouth curled into a ghastly smile, as if he meant mischief. The cunning brute had contrived to push back the door of his den, while his keeper had gone for the carpenter to mend some defect in it. Having warned every one to keep out of the way, Mr. Bartlett called his keeper, who tried to coax the hippopotamus back with sweet hay. The brute munched the hay, but showed no sign of going back. What was to be done? Mr. Bartlett is a man of unfailing resource. There was one keeper Obash hated, and ran at him whenever he came in sight. 'Scott,' said Mr. Bartlett, putting a bank note in his hand, 'throw open the paddock gate, and then show yourself to Obash at the end of the path, and run for it.' The man looked at the note, and then through the trees at the beast, and, going into the middle of the path, shouted defiantly 'Obash.' Ugh! roared the beast, viciously, and wheeling his huge carcase suddenly round, rushed with surprising swiftness after the keeper. Scott ran for his life, with the hippopotamus roaring at his heels, into the paddock and over the palings, Obash close to his coat-tails; bang slammed the gate, 
and the monster was caged again. Just then, up drove a cab with a newspaper reporter. 'I hear,' he said, 'the hippopotamus is loose!' ' Oh dear no,' innocently replied Mr. Bartlett, 'he is safe in his den; come and see.'

The winter of 1874 was a severe trial to the animals of the Zoological Gardens. Frank Buckland visited them in the coldest weather, and attracted public interest in their condition by a letter to the 'Daily News.'

'During the past severe frost, many of our readers, when assembled round the Christmas hearth, have doubtless remembered the poor animals in the Zoological Gardens. At the very height of the frost, we paid a visit to the Gardens. They presented, indeed, a most forlorn aspect, contrasting greatly with their brilliant appearance on a summer's afternoon. Everything seemed frozen up, and many of the houses were defended from the frost by various contrivances, and the inmates themselves were seldom visible. The Polar bears, the beavers, and seals, alone seemed to enjoy the cold weather. The smaller Polar bear is a female. She has bred twice-two cubs at a time. When born, each is about the size of a large rat. The cubs were put to a foster-mother, but the little wretches were so disagreeable that the canine mother would not attend to them. The seals seemed perfectly happy, and to enjoy the frost and snow much more than they do the summer weather. Out of the four Bladdernosed seals, that were presented to the Society by Captain Gray, only one remains alive, and he is the big male. When he first arrived he was fed on eels, but now he eats sprats, whiting, and baddocks, and, with the other seals, is a very expensive pet. Old Le Compte, the seal-man, 
informed us, "Que les seals ont bien passé leur Christmas avec une double ration de poissons." Le Compte has kept the ice in the big round pond broken, and the seals (especially the two sea-bears) have advanced considerably in their education, particularly in the art of catching fish in their mouths, when thrown from a distance; the big one will "field" the fish with a dexterity to be envied by cricketers. It will be observed that the smaller sea-bear shows his flipper as he swims in the water, so that he might be easily mistaken for a porpoise; the other sea-bear does not show his flipper at all.

'The beavers are quite at home in the cold and snow. Three holes were opened for them in the ice, and were kept open by the beavers themselves continually passing through. This is probably their habit in far distant Canada and North America. It was very interesting to see the beavers collect the snow, which they do by pushing a heap up together; they then collect it between their fore paws and chin, and half push half carry it along. One cunning rascal made a snow hill at one corner of the enclosure, a clever bit of engineering, by means of which he evidently intended to have escaped, by going to the top of the snow hill, and then dropping down the other side. Another of these beavers was evidently not quite satisfied with his present home, and had set to work to improve it. This fellow collected a quantity of snow, and piled it up as a kind of extra thatching on his "hut," as it may be really called, in the middle of the pond. The inside of this "hut" is said to be tunnelled in a most remarkable manner. There is a story extant, not only in schoolrooms but even much higher, probably originated by Peter Parley, 
that beavers use their tails as trowels, to flatten down the mud, which forms the roofs and sides of their huts. They never do anything of the kind; they use their tails for sitting on their haunches, and for steering themselves in the water. They also have the power of slapping the water with a loud noise; this is done as a signal when in danger.

'During a very hard frost some four years ago, the rhinoceros fell through the ice which covered the pond of his enclosure: he was then very nearly drowned, but was cleverly hauled out from his perilous position by means of ropes. This year, the moment the frost was gone, the ice was removed, and the rhinoceros let out to have a bath. The old thing would not take the usual plunge, but, just putting her toes into the water, instantly drew back, the water evidently being much too cold. The elephants and the other large animals in the new elephant house, and the giraffes and elands also, have preserved good health during the severe cold : the houses are kept at an agreeable temperature by means of hot-water pipes. The mother hippopotamus and Guy Fawkes, the young one, who has grown amazingly, are also quite well. The water in which they bathe inside the house is always kept warm at as near $55 \mathrm{deg}$. as possible, and they seem thoroughly to enjoy their perpetual walm bath. 'The ant-eater retired under' a mountain of straw, only turning out at dinner time. In the ant-eater's house is a large tank nearly full of alligators, crocodiles, turtles, etc., which make a great splashing when disturbed. The structure of the lungs of these creatures enables them to remain days-nay even weeks, sometimes months-under water without breathing. 
About a week ago a very fine crocodile arrived, some four feet long: he was nearly stiff with cold, but being put before the fire he gradually thawed, and was placed in the tank, where he has become quite lively in his hot bath.

"The snakes and reptiles are reported "all well." The temperature in the cages is kept up to about $90^{\circ}$, and the snakes are covered carefully with thick blankets. The only effect that the cold has is to take away their appetite. Many snakes will not feed during the severe weather, even although provided with the greatest luxuries of the season, viz., little hairless blind rats. A good many rats are bred on purpose to supply the snakes with this muchcoveted delicacy. The value of a full-grown fat rat is twopence; they are most useful for food for the hawks, eagles, \&c. The score is kept by the tails being taken to the office.

'The latest arrival at the Gardens is an immense toad, called the giant toad, from the Brazils, the largest known toad. This fine fellow measures seven inches in length, and is broader than he is long; he eats white mice and common frogs, and has great glands on his head from which he can eject a kind of poison.

'During the frost a covering was put on the front of the dens of the lions and tigers, and none have suffered. Each lion's allowance is eight pounds of horse-flesh per day. A few days ago Mr. Bartlett performed an operation upon a female tiger. Her claws had grown so much that they had penetrated the pads of her foot. Mr. Bartlett lassoed her by the neck, afterwards by means of straps pulled her feet out between the bars, and with sharp nippers nipped off the points of the claws. When the 
tigress found what was being done gave her no pain, she showed little or no resistance.

"There are now one hundred and two animals in the monkey house, all well. There are just now some very remarkable monkeys. One is a Macaque, a perfect albino; his hair is as white as the beard of an old man, his pink eves like a rabbit's, and his hands and nose are like blancmange. There is also a very remarkable monkey called "Patas," or Hussar Monkey. He looks like a greyhound, and is of the colour of a fox; the keeper calls him therefore "Sandy." Another is the Wanderoo, a fellow with a great mass of hair round his face and the most awful teeth ever seen in a monkey's mouth. This monkey has been credited with having killed two niggers before he was caught; he comes from Malabar. Other monkeys worth notice are a new marmozet with red ears, not yet named, and a Japanese ape; also a very wonderful monkey from South America, with a face like a sloth, and three very beautiful spider monkeys. The way in which these monkeys swing and cling by means of their prehensile tails is very interesting. The monkeys' food consists of bread and milk, boiled rice, apples, carrots, potatoes, \&c. The temperature of the house is kept at about 60 or $65 \mathrm{deg}$. Poor Joe, the chimpanzee, has been made into a skeleton long ago; he died, like most of our London monkeys, of tubercles.

'As regards the birds, it is interesting to know which are most hardy. The beautiful Crossoptilon from Northern China, the pheasant who wears lovely whiskers eacl side of his eyes, does not mind the cold at all, coming from a naturally cold climate. This bird is very tame, 
and promised some time ago to become a domestic bird; but having bred to the third generation they generally die off; perhaps the reason of this is, that in their native home they migrate and change food at different times of the year. Lady Amherst's pheasants are also hardy; they come from Northern China. This bird crosses freely with the gold pheasant, producing a bird of amazing beauty; and, unlike hybrids or mules, the offspring are as fertile as their parents. By this beautiful cross, therefore, a new race of the most beautiful pheasants in the world has been produced. Another very beautiful and interesting bird, in excellent health, is Stanley's jungle fowl; its home is Ceylon; these birds are worth 50l. per pair. A collector, who did not know their value, procured seven of them alive at Trincomalee, and had them cooked for dinner -rather an expensive feed, three and a half pairs of fowls of the value of $175 \mathrm{l}$. One would have supposed that this bird coming from Ceylon would require heat, but they belong to the mountains, which are cold and damp. There are only three species of white storks known-the European, the Japanese, and the South American. These are all represented in the Gardens. The Japanese stork is still white, the other two have got dirty with the London smoke. The Crown Pigeon, of New Guinea, a bird nearly as large as a turkey, with a beautiful crest on his head, thrives in this country, and is a grand bird for the aviary, or the lawn in front of the drawing-room. Another bird that should be acclimatised is the brouze-winged pigeon of Australia. The wings of these pigeons are more brilliant than the mother-of-pearl on a lady's fan. 'They require little more care than the common pigeon. In the large 
aviary are a considerable number of guans and curassows. These birds would make excellent farmyard birds as a superior kind of turkey, but unfortunately they will not lay eggs. Another" peculiarity is that they lose their toes in the winter; if the frost at all touches the toes they drop off. A bird can be seen in this condition in the curassows' cage. The extraordinary and beautiful aquatic bird, the darter, from South America, is in good health, but he is moulting. The visitor should remark the clever way in which he transfixes a fish with his beak before he swallows it.

'The only deaths that can be attributed to the frost are a curassow, an armadillo, a natter jack toad, and a chameleon. These deaths are not to be wondered at considering the hot climates these animals come from. That so few losses have occurred is certainly attributable to the exceeding care, practical experience, and constant supelvision of Mr. Bartlett; careful regulation of temperature, and an increased supply of food for every animal in the Gardens, are found to be the best means to ward off sickness in cold weather.'

In 1873 Frank Buckland published, through the Society for Promoting Christian Knowledge, a History of British Fishes, an enlarged edition of which was the latest labour of his life.

Numerous lectures were delivered in these years at the Society of Arts, at his museum in London, and at many country places; by which he endeavoured to spread more widely the knowledge of and interest in fish and oyster culture, and the love of natural history.

His museum he constantly added to, at great personal 
labour, casting fish and painting the casts ; and he loved to show the fruit of these labours to those who would share his interest in them, and his keen eye brightened with delight as he explained and told stories of the different objects he had collected. Sir Bartle Frere, Sir Philip Egerton, the Dukes of Argyll, Sutherland, Wellington, and St. Albans are noted as amongst his visitors; the Marquis of Bute also, whom he aided to restock the Isle of Bute with beavers, the Archbishop of York, and the Bishop of Limerick, the Maharajah Duleep Singh and many others; with no less pleasure he records, on Easter Monday 1873, 'Thousands of people in the Museum; a great and decided success, thank Goodness.'

Legends of huge sea monsters, clasping boats or even ships in their writhing arms, had long. been current, but were little credited by naturalists. Such stories in a modified form became multiplied as the wonders of the sea were more constantly observed. In December 1873 , Frank Buckland received through the Colonial Office official papers and photographs describing parts of a monster cuttle-fish caught off Newfoundland. Its dimensions were soon rendered palpable to popular view. The shape and length of the body and tentacles were cut out in boards and hung in his museum, showing a sea monster with arms thirty-five feet in length.

Besides literary and museum work, he gave evidence before the Parliamentary Committee on river pollutions, whose report led to an important statute passed in 1876 ; and he repeatedly visited Windsor to examine the drainage works there, at the same time watching over the results of fish-culture carried on in Windsor Park, and receiving 
from Prince Christian instructions to survey and report on all the lakes and ponds in the park.

On July 22, 1874, at the Jubilee Anniversary of the Society for the Prevention of Cruelty to Animals, he ' went on the platform and made a speech about cruelty to seals. Nuch applauded. Deo gratia.'

The cause of the seals, which for several years he earnestly and successfully advocated, was thus stated in a letter to the 'Times,' in March 1875 :-

'Captain David Gray, of the sealing and whaling ship "Eclipse," and myself first brought forward, some three years ago, the necessity for a close time for Arctic seals. The principal sealing-ground is at Jan Mayan Island, 1,300 miles due north from London. Seals resort to this island and thereabouts to breed. There are four species inhabiting the Greenland seas, viz. the harp or saddle-back, the bladder-nosed or hooded seal, the bearded seal, and the floe rat. These seals are none of them fur seals, but yield oil worth $50 l$. per ton. Seal and whale oils are the only oils which will dress jute properly. Jute is a regetable fibre grown in India and largely used in British manufactures. The annual value of the seal oil from the above fishings is about $250,000 l$. This great commercial interest is now in jeopardy, inasmuch as, unless there is some speedy legislation, the seals will be utterly destroyed. A fleet of ships is engaged every spring in this work of destruction. Twenty steamers and a few sailing vessels go from this country, especially from Peterhead and Dundee, twenty-seven are Norwegians, of which twelve are steamers, five steamers sail from Germany, two from Sweden, and one Dutchman; in all sixty sail. The ships arrive at the 
ice from the 15th to the 20th March, just as the young seals are born. The seal hunters at once attack them, and most horrible cruelty ensues. I quote Captain Gray's own words to me. "Last year the fleet set to work to kill the seals on March 26, 1874, and in forty-eight hours the fishing was completely over, the old seals being shot, wounded, or scared away, while thousands upon thousands of young ones were left crying piteously for their mothers. 'l'hese mostly perished of famine in the snow, as they were not old enough to make worth while the trouble of killing them. If you could imagine yourself surrounded by four or five hundred thousand babies, all crying at the pitch of their voices, you would have some idea of the piteous noise they make. Their cry is very like that of a human infant. These motherless seals collect into lots of five or six, and crawl about the ice, their heads fast becoming the biggest part of their bodies, searching no doubt to find the nourishment they stand so much in need of. These little seals are called cats, they increase in size exceedingly fast, and if left to grow for a few days, the oil would be of value, while their skins, used for patent leather, and boots of the best quality, would be valuable."

In 1876 an international close time was established, prohibiting the killing of seals in these seas until after A pril 3.

This arrangement, which became effective in 1877 , has increased the value of the fishery by allowing the young seals to grow to a value four or five times greater than as they were before recklessly slaughtered, and has nearly put a stop to the destruction of the mother seals. It 
affords no protection, however, to the bladder-nosed seals, which breed in June; nor does it prevent the entire young brood of the year being killed; some further protection is therefore needed.

'I am quite certain,' writes Captain Gray, 'that I could not have got the close time for seals established without the aid of Frank Buckland.' 'I first knew Mr. Buckland,' he adds, 'personally in 1870; he came to Peterhead about salmon-fishing, and he was the man I wanted most to know in the world. We took to each other at once, and continued great friends until his death.'

The anniual slaughter of seals is prodigious. About 80,000 saddle-backed seals, and a like number of hooded seals, are killed every season in the Greenland fishery, while the Newfoundland fishery destroys an equal number. Some reasonable restrictions are necessary, or the race must become extinct.

The fur seals, which provide the seal-skin cloaks, are a distinct species from those above mentioned. The furseal fishery is confined to the Aleutian Islands, on the north-west coast of America, part of the Territory of Alaska acquired by the United States from Russia in 1867.

This fishery is let by the United States, under careful regulations for the preservation of the race of fur seals. The young males only are killed, at the age of three or four years, when their skins are most valuable, and the number annually taken is limited to 100,000 , a number which, large as it is, does not diminish the fishery. 
Other nations may well take example from this wise care. ${ }^{1}$

One principle pervaded Frank Buckland's writingsto show, as his father had done, the evidence of design and skill in all created things. Of this the following paper, on the evidence of design in the structure of the fish, crocodile, armadillo, tortoise and hedgehog, is an example. It appeared in 'Land and Water' in July 1874:-

'It is very interesting to observe the wonderful way in which the Creator has clothed and ornamented his various creatures. Some live in the water, some on land, some pass their time partly in the water or on land, some exist partly in the air, on the water, and on the land. All are beautifully and wonderfully constructed. I propose now to make a few remarks on the external coverings of some of these; taking as a beginning the various modifications of horny coverings.

In the scales of the fish (the carp is about the best example) we find plates of thin horn, somewhat resembling, when cleaned and boiled, a portion of an ordinary horn lantern. These plates are set each in a soft pocket of the true skin, and overlap each other so as to form a complete suit of armour, giving origin, no doubt, to the idea of scalearmour, as worn by our ancestors at the time when arrows were used in battle. The scales in the fish are not all of the same size; they are beautifully fitted, like enamel plates, on to the body, so that while they afford the most efficacious

1 In the Fishery Exhibition of 1883 an admirable series of specimens of the fur seal was shown by the Alaska Company, the lessees of the fishery, together with drawings and descriptions of the method of carrying on the fishery. An excellent article on the fur-seal fishery also appeared in the Quarterly Revien for October 1883. 
THE ZOOLOGICAL GARDENS AND SEAL FISHERIES 297

protection, they will not interfere in the least with the movements of the fish, which in many instances are exceedingly rapid.

'Passing on from the fish to the crocudile, we again find a scale-formed armour. The scales in this case are let into the skin in a different manner to those of the fish, and they are capable of absorbing a considerable amount of water. This I found out by soaking a crocodile's skin in water. Before the skin was soaked, it was as hard and inflexible as a board. Having been soaked a few hours, it became almost as pliable and soft as a wet towel. This is evidently an arrangement to enable the crocodile to pass his time with comfort, both in the water and out of the water. A crocodile also has lungs, not gills, and we never find true scales, like those of a fish, unaccompanied by gills. When the crocodile is basking in the sun, his scales are much harder than when they are in the water.

'If we look for scales in land animals, we shall find therm, more especially in the pangolin, the armadillo, and the tortoise. The pangolin's scales are very like, but yet differ from, fish scales proper, inasmuch as they are not intended to be wetted. In the armadillo we find a series of scales of peculiar shape, not let into pockets as in the fish, but each connected with its neighbour by soft skin, so that the armadillo's skin may be said to be a series of oblong-headed nails (such as are used to tack on furniture fringes), fastened into a covering, which forms the skin of the animal. The armadillo has to roll himself into a ball as occasion requires, therefore the studs of his armour are so beautifully fitted as to size and shape, that he can roll 
them up into a ball without the slightest appearance of a crease or wrinkle.

'In the case of the armadillo, who lives under a covering. of horny flexible skin, please to observe that his backbone, and all other bones, as well as his lungs, heart, and other viscera, are all underneath this flexible roof to his body. In the tortoise we find quite another arrangement. Take a tortoise-shell and boil it, and you will find that you can pick off the scales one by one, and underneath the scales is a tenter-house of solid-formed bone. This dome-shaped house is not composed of a continuous mass of bone, as a tea-cup is made of a continuous plate of pottery, but rather of a series of small bones, all properly arched to suit the original curve, and jointed together in a most marvellous manner. It was not possible to rivet or bolt these plates together. Mortar could not be used to bind them together, as in the case of an arch made of bricks. What then must be done? If the reader will examine for himself, he will find that the edges of each bone are deeply serrated, and that the serrations fit in such a workmanlike manner one into the other, that an amount of solidity is gained which could not have been equalled if the whole dome had been cast in a solid piece.

'But how is the tortoise to live in his house? Where are his ribs to go to? Let us examine. In ordinary animals the backbone forms an attachment for the ribs, and there are plenty of muscles outside the ribs. In the tortoise, the ribs themselves are actually used to form part of the dome or roof. By examining the inside of a tortoise-shell, the fact will at once become apparent. The ribs will be seen forming the girders of this wonderful 
roof, and they are connected together by means of the abore-mentioned plates of bone and denticulated edges, while the centre portion of the bone sends down an arch to form a canal, in which the spinal marrow is contained.

'The tortoise therefore lives inside a house, which is composed of his own ribs formed into a dome, and he rests upon his sternum or breast-bone, which is flattened out into a broad plate, to serve, first, for the attachment of the ribs, and, secondly, as a kind of supporting foot or basement. Can there possibly be a more beautiful piece of design than this, which combines economy of material and great strength with lightness?

'We often find the same design in created things utilised for rarious purposes. It is therefore highly interesting to find that the same kind of denticulated suture as adopted in the tortoise is present also in our own skulls. A bony box is required to carry and protect the brain; the human skull therefore is formed of bones, each being joined to its neighbour by identically the same kind of union as that in the tortoise. There is in the human skull another meaning for this: the interposition of several lines of sutures all over the skull prevents a fracture of one of the bones of the skull spreading to its neighbour, just as the woodwork in a window frame prevents the fracture of an individual square of glass spreading to the adjoining squares.

'In the common hedgehog we find a very curious bit of mechanism. The hedgehog has no horny studs fastened into the skin, as in the armadillo, nor yet has he a bone-formed dome, covered with horny scales, as in the 
tortoise. Instead of this, his horny covering assumes the form of spines, or bristles, each set firmly into the skin at one end, and very sharply pointed at the other end. These bristles the owner can erect in groups, with all the points outwards, presenting a formidable array of weapons; but the hedgehog has also power to lay back all these sharp-pointed spines in one direction, viz. from his head downwards. In this position they form a carpet, which, if smoothed the right way with the hand, is as soft as velvet. To find out how all this mechanism is carried out, I have dissected a hedgehog, and was surprised to find how very slight are the muscles which command the spines. They are fine strings or fibres very similar to the ' corrugator supercilii,' or frowning muscle in our own forehead; in fact when a hedgehog curls himself up, he begins work with a tremendous frown as he tucks his head inwards. The muscles that work the spines are attached to the spines which project from the back-bone, and also more especially on to the ribs, which I find to be of unusual strength and abnormal width for so small an animal. The vertebræ are attached to the ribs in a very peculiar manner, and each of the back-bones fits on its neighbour by a wonderful joint, which keeps the chain of bones quite stiff when the animal is walking, but which enables him to coil up into a ball on the slightest provocation.

'I find that the hedgehog has a clavicle or collar-bone, evidently for the purpose of using his forepaws for digging. His digging-claws are also peculiar, and, when curved together, assume a shape very like that of the ant-eater, who pulls down the ants' nests with his tremendous claws. 'Such, then, are a few examples of "design, beauty, 
and order" which have lately come under my notice in my dissecting-room.

'N.B.-I am sadly in want of mole-crickets, dead or alive. Any so-called vermin will be also acceptable.'

A long inquiry of nine days, in December 1874, into the bye-laws for the Wye fishery, was diversified by an examination of the peal of bells in the beautiful church of Ross.

'One evening during the progress of the inquiry, when inspecting the shops, a magnificent peal of bells began to ring. Having but once before seen a church belfry, when they were ringing a peal, I determined, if possible, to get up into the belfry. With some difficulty, having no light, we found the little door at the base of the tower, and, after shouting awhile, a man came down with a candle in an ancient horn lantern. I then went up and up and up some very narrow and much worn stairs, till I arrived at the belfry. Imagine a largish room quite square, four bits of candle burning a dim light, from the ends of a very primitive chandelier made up of laths, a creaky floor, a roof of antiquated timbers, an old man and a charity boy on a form in the middle, the solemn tick, tick, tick of the cliurch clock, and eight men, each standing by a rope, and you will have some idea of the scene which presented itself to my view. The chief of the ringers gave me a very kind welcome; and after giving some mysterious orders to the ringers, who went each to his rope, at a given signal off went the merry bells, $1,2,3,4,5,6,7,8$, again and again for about five times. The leader then cried loudly, "Bob"! and the bells instantly altered to (as I understoud afterwards) $2,1,3,5,4,7,6,8$; then to $3,2,1,4,5,6,7,8$; and so on for a cousiderable time, interspersed with the 
orders loudly given every now and then "Sing]e "! "Bob"! till at last the poor bells seemed suddenly to recover their senses, and away they went loudly $1,2,3,4,5,6,7,8$; and then "Halt!" This peal-ringing was evidently hard work, but the music was beautiful. It was a peal of "Grandsire Triplets," whatever that may mean. Grandsire, I believe, is the name of a man who was a great authority on bell-ringing. An inscription on the wall was pointed out to me with evident pride, which reads as follows:-" February 11, 1851, was rung in this tower a true and complete peal of Grandsire Triplets, containing 5,040 changes, in three hours and two minutes, being the first true peal ever lung in this country." Then came the names of the ringers.

' I was then permitted to ring a bell, and was surprised to find the tremendous velocity and power with which the rope, at a certain stage of the pull, rushes upivards. This is very dangerous to novices, who might get entangled in the rope, and smashed by it against the roof above. It requires great knack to pull the rope at a certain instant so as to make the bell speak. How the men manage, under these circumstances, to ring a peal, especially with changes, I cannot understand. I was told that the bells were ther " raised," that is they were standing with their mouths uppermost, and, as time was getting on, the ringers must "fall" them, i.e. bring them very gradually back to their original position, with the mouths downwards. This "falling the bells" took some time, during which many musical combinations took place most enchanting to the ear; they ended, as usual, with a half-faint $1,2,3,4,5,6,7,8$.

'I spread the news of my discovery of the bell-ringers at Ross Church among those present at the Inquiry, and 


\section{THE ZOOLOGICAL GARDENS AND SEAL FISHERIES 303}

the ringers promised to ring us another peal the following evening. We had to wait till the evening church service was over, when a goodly company of strangers visited the belfry. The ringers then took extra pains with their complicated change ringing, which is far beyond my comprehension, and even, I have reason to know, past the understanding of the learned lawyers assembled. They cross-examined the ringers again and again, but could make nothing of it. I never saw lawyers so completely stumped before, and this by eight honest hard-working men, a mason, a wheelwright, a tailor, a tallow-chandler, a shoemaker, a ploughman, \&c. Trahit sua quemque voluptas was here well exemplified. The lawyers knew their business, the ringers knew theirs. When the men had rung a beautiful peal, they offered to muffle the bells in our honour. The bells are generally only muffled at Christmas. Muffling the bells, I was told, means tying a bit of leather on to the clappers, so that the sound is subdued. While two men went up to muffle the bells, the ringers sat down in a row on a form, each with a hand-bell in his hand. By interchanging these bells they rang a very pretty peal, and then standing up, played several good tunes on these hand-bells.

'The bells being now muffled, the men rang another peal, the effect of which was exceedingly beautiful. I then with my colleague, Mr. Walpole, went right up into the steeple, and stood upon the beam, close over the eiglit great bells, as they were giving out their iron voices. The noise here was tremendous. By signs alone could we speak, but it was a grand sight to see the bells swinging in great circles, with tremendous power and swiftness, and hen to see them instantly stopped in their wild career, 
and made to speak by the comparatively feeble hand of the man at the rope below. The sight of these eight bells all swinging, apparently madly, and without order, and yet giving out a most musical peal, which (when the bells are not muffled) can be heard eight miles off, was grand in the extreme. After looking well at the bells, I sent down word to ask the ringers to "fall" them; and it was very interesting to see, how neatly and gently the bells began to lessen their speed, then seem to despail of their work, then labour heavily at it, then begin to slumber, and at last fall into the deep heavy sleep, which they have enjoyed more or less for one hundred and eighty years. Only fancy one hundred and eighty Christmas days! Taking a generation at thirty years, these bells must have rung their Christmas pea] to no less than six generations of the inhabitants of Ross since the reign of king William IIT., A.D 1695, when the "Man of Ross," John Kyrle, gave the big bell. It is said that the Man of Ross was present at the casting of the tenor or great bell, and that he took with him an old silver tankard, which, after drinking claret and sherry, he threw in and had cast with the bell. By a curious coincidence this bell unexpectedly fell off the wheel soon after John Kyrle's funeral.'

Frank Buckland was elected corresponding member of the Zoological Society of Philadelphia, an honorary member of the Chester Society of Natural History, presided over by his friend Canon Kingsley, and a member of other local associations.

He still found time for many public and social engagements; exhibiting objects of newest interest from his collection at the soirées of the Royal Society and College 
of Surgeons; attending meetings of the Fisheries Preservation Society, under the presidency of the Duke of Northumberland, and of the Thames Angling Association, who presented him with a diamond ring and a watch and chain in testimony of the value of his aid.

He also received an exhibitor's medal for his contributions to the International Exhibition of 1873 at South. Kensington.

In 1874 he delivered two lectures at the Society of Arts on Natural History, followed by a lecture at his Museum, and another at the Brighton Aquarium, when he gave prizes to his younger hearers for the best essays on his former lectures; he also lectured at the opening of the Manchester Aquarium in May 1874, and at Harting, Sussex, in the same year.

Two young nephews called in Albany Street while he was preparing for the Brighton lecture. The old rhinoceros at the Zoological Gardens had lately died, and Frank Buckland was busy making a huge pie of a portion of the carcase, to be distributed among his Brighton audience. The nephews came in for an anticipatory share. It was like very tough beef.

He met the Prince and Princess of Wales, and later the Shah of Persia, at Earl Granville's. Dined at the Wykehamists' and St. George's Hospital and other public dinners; wrote an article on the Two-headed Nightingale; called on them and the giant and giantess, Captain Bates and Miss Swan. The Two-headed Nightingale returned his visit, and le entertained the giant and giantess at dinner in honour of their marriage, on which happy occasion the 'L'wo-headed Nightingale officiated as bridesmaids. 


\section{CHAPTER XIII.}

SPECIAL INQUIRIES, NORFOLK BROADS: CRABS, LOBSTERS, AND OYSTERS, HERRING FISHERIES, \&C. : 1875-1877.

From salmon, sea-birds and seals, Frank Buckland's care was extended to other freshwater fish, crabs and lobsters, oysters, and sea-fish in general.

'Salmon fisheries,' he had written in 1871, ' do not form the only part of aquiculture that requires development by means of scientific attention and regulation in this country. There are thousands of acres of fresh water, such as the lakes in various parts of England and Wales, the Norfolk broads, and even comparatively smaller lakes and ponds in private parks, the cultivation of which is now absolutely neglected.

'By the judicious administration of rules as to close time, netting, \&c., for freshwater fish other than salmon, tons of white fish may be grown as food for the people, a kind of food which would find a market in large manufacturing towns; while at the same time sport for the anglers of London and its vicinity, as well as those of the large inland manufacturing districts, would be greatly increased.'

An ardent fisherman himself, he thought it an object of national concern to provide the working classes with healthy sport. 
In 1875, Frank Buckland was instructed by the Home Secretary to inquire into the state of the crab, lobster, and other sea-coast fisheries on the coast of Norfolk; and ascertain whether they should be placed under regulations to prevent waste, and to preserve them in future.

His report, after several weeks of careful inquiry, was presented in Angust 1875, and contained various information; other notes, gathered at Yarmouth, were also published. ${ }^{1}$

The growth of the herring fishery is noticed : 422 millions have been landed in one year at Yarmouth and Loivestoft alone, yet no diminution of the herring has taken place within the memory of man. Many boats fish with one or two miles of nets, and five or six thonsand miles of nets are laid for herring on favourable nights in the North Sea. The mackerel fishery is there comparatively unimportant, the trawl fishery of great value, about 1,000 large trawling vessels going out from Yarmouth and Lowestoft.

The Norfolk broads, the Report states, 'are freshwater lakes varying in size and depth; there are nearly fifty altogether in Norfolk and Suffolk. If the Serpentine was surrounded by a jungle of reeds and rushes extending a considerable distance out from the bank, a good idea of a Norfolk broad on a small scale would be obtained. They form a chain of inland lakes, containing nearly 5,000 acres of water, connected with the sea by abont 200 miles of river, the greater part of which is navigable.'

In these broads tons of fish and fry were yearly destroyed by unregulated netting, and by the cutting of the

' Notes and Jottings from Animal Life, p. 184. 
water weeds when laden with fish spawn; and it appeared advisable that the freshwater fisheries of Norfolk and Suffolk should be scientifically cultivated. All classes of society dwelling in the neighbourhood were willing to take this matter in hand. The rivers and broads were admirably adapted for the breeding and fattening of such indigenous fish as belonged to the species of carp, bream, perch, and so forth. The temperature of the water in the spring and summer months was favourable to the breeding of these tish; fish of this kind do not, like the salmon, require gravel beds and lunning water; they, on the contrary, naturally deposit, or rather suspend, their spawn on the water weeds and other aquatic plants. The borders of the broads are for the most part margined with dense jungles of weeds, while the bottom is planted with forests of subaqueous vegetation, so that there are many hundred miles of sparning ground available for the fish which live in these waters.

Common yellow river trout were also found in the broads, and new species of fish might be introduced.

The Report also dealt with the oystel, mussel, and whelk fisheries of the coast, the whelk fishery at Lyun alone yielding about $6,000 l$. a year.

The crab and lobster fishery, which formed the principal industry of the coast near Cromer, had fallen off to a serious extent, owing to the wholesale destruction of the young crabs, locally called toggs.

At Cromer the fishermen generally threw back the toggs into the sea, but at Sherringham, a neightouring village, they were kept and sold. One fish merchant estimated that 28,000 undersized crabs, worth barely one 
frithing each, were brought ashore and sold at Sherringham in one day.

The crab fishers of Cromer have a peculiar arithmetic, thus two crabs are counted as one. The two crabs being called a cast, six-score of crabs is called a hundred. At Cromer, therefore, a hundred crabs means 240.

The lobster fishery was also diminishing from the sale of undersized lobsters from 4 to 6 inches long.

The Report made various recommendations, including protection for the broads, a close time for the crabs and lobsters, and the prohibition of the sale of undersized fish, crabs, and lobsters.

An Act was passed in 1876, regulating the crab and lobster fishery of Norfolk; and another Act was passed in 1877, after a Parliamentary inquiry, before which Frank Buckland gave evidence, for the protection of the fisheries in the broads. A general inquiry was also directed into the crab and lobster fisheries of the United Kingdom, preliminary to considered legislation on the subject.

This inquiry was held in September, October, and November 1876, by Frank Buckland and Mr. Walpole for England; and by the same Inspectors, with Mr. Archibald Young, for Scotland. The Irish Fishery Inspectors also held an inquiry, and in result an exhanstive report was presented in March 1877, which formed the basis of a further Act passed in the same year regulating this subject.

To this report, which collected a variety of curions information, was appended an interesting paper by Frank. Buckland on the Natural History of Crabs and Lobsters.

'We eat dressed crab, and lobster salad, and refresh our wearied brains with the stores of phosphorus they con- 
tain, yet those brains give little thought to the strange unseen life of these creatures, which by hundreds of thousands are caught for us by toiling fishermen in British seas, while 600,000 lobsters are yearly brought from Norway to eke out our supply. Before the young crabs are born, the mother crab tucks up, under her tail, her numerous family of from one to two million coral-like eggs (it is the lobster, gentle reader, not the crab, turns red in boiling), and she sidles on tiptoe many a mile from her rocky home, to some sandy flat in the deep sea, where her young family may flourish best. There, or perhaps on returning home, in early spring, the time for all young things to come forth, the tiny crabs burst the egrg; yet so unlike their parent, that till lately they were thought some strange animalcula; goggle eyes, a hawk's beak, a scorpion's tail, a rhinoceros' hol'n, adorn a body fringed with legs, yet scarcely bigger than a grain of sand! Several strange shapes are assumed in turn, ere the young crab attains the parent form. For the parents of so uumerous a family it is well that mature has provided the young crabs with a strong suit of clothes, which does not wear out; but it is quickly outgrown; the young crabs shed from time to time the horny case, even to their finger-uails and eyelids; and mother nature straightway provides, underneath, a new, soft leathery suit, which quickly hardens into shell. Another marvel is that the growth is, as it were, by leaps and bounds; each time it bursts its case, the young crab swells suddenly to twice the size of the discarded shell.

' In crab youth several new suits are annually required. In maturer life the lady clab, it seems, is content with one new dress each year ; yet is not the romance of life over. 
In the time of her soft-shelled weakness and seclusion, a male crab in full armour constantly attends her, guards her from danger, and solaces her in her retirement. An old crab's shell covered sometimes with barnacles, or with cysters of several years' growth, shows that the patriarch has outlived the change of fashions which occupied his youth.

'The lobster in its infant transformations and later growth differs little from the crab. These are the scavengers of the seas, and like high-flavoured food, which the nicer crab would reject.'

Frank Buckland's full account of the structure and habits of these curious creatures may be read with interest.

'The stormy seasons of the rocky coasts frequented by crabs and lobsters give, for the most part, a sufficient natural close time for this fishery; and it was only found needful to provide by legislation against the sale of undersized crabs and lobsters, and of crabs at the breedingtime, when, unlike lobsters, they are unsuitable for food, and also of soft-shelled crabs.'

A curious and kindly episode is contained in this Report. 'The Fishermen at Hall Sands keep four or five Newfoundland dogs for the purpose of carrying lines from the shore to the boats in rough weather. The surf is so heavy in certain winds, that the only possible way of landing is for the boat to be drawn through the surf by the friends of the fishermen on shore, by means of the lines which the dogs take out to them. The fishermen think it a great hardship that these dogs should be taxed. We promised to draw the attention of Her Majesty's Government to the matter, and we have noticed it accordingly here.' 
In 1876 a Parliamentary Committee on Oyster Culture sat to inquire into the reasons of the scarcity of oysters, the effect of the recent legislation, and the expediency of further measures.

Frank Buckland gave evidence before this committee, which eventually recommended the extension of the close time for oysters to the whole of the months from May to September inclusive, except as to the deep-sea fishery, the close time for which was fixed by international regulation from June 15 to the end of August. The committee also recommended the prohibition of the sale of undersized oysters, and the encouragement of private enterprises for breeding and feeding oysters on the foreshore. The report led to appropriate legislation in 1877 .

The use of dynamite for the destruction of fish formed the subject of a special inquiry and report by the Inspectors in 1877, and of a consequent Act of Parliament.

In the same year Frank Buckland, with Mr. Walpole and Mr. Archibald Young, were appointed Cominissioners to inquire into the condition of the herring fishery on the coast of Scotland. Several weeks in August and September were occupied in this inquiry, H.M.S. 'Jackal' being appointed to convey the Commissioners to the Shetland and Orkney Isles, and various places on the coast. A pleasant description of their crnise, with other notes from Scotiand, is contained in 'Notes and Jottings.' '

For nearly seventy years the Scotch herring fisheries have been superintended by the Board of White Herring Fishery; their importance, however, justified a special Commission. In February and March spawning herring are

' Pp. 141-173. 
canght off the coast of Ayrshire. In May and June shoals of young herring, with undeveloped roe, swarm in the Ninch, the narrow sea lying between the Hebrides and the north-west coast of Scotland. These are called matties or maidens, and 'are principally sold in the Russian markets, where they are regarded as a delicacy, and the great Russian families are in the habit of obtaining for their own use an early barrel of Scotch matties.'

From July to September the herring have reached the south-west coasts and Loch Fyne, the Loch Fyne herring being specially valued for their size and flavour. In the same months the great herring fishery on the east coast takes place, the fish there caught being mostly spawning or breeding fish. Late in the season spent, or shotten herrings are taken, and are sold as of inferior quality in continental markets.

These are the principal herring fisheries in Scotland, though herring are caught throughout the year.

The annual take of herring is prodigious. About a million of barrels, representing $800,000,000$ fish, are taken in Scotland; the Norwegian herring fishery is as productive as the Scotch fishery; and the English, the Irish, the French, and the Dutch fisheries are also very productive. Estimating the gross produce of these four fisheries at only the same amount as the Scotch fishery, $2,400,000,000$ herring must be annually taken by these four nations, the British, the French, the Dutch, and the Norwegian. Yet the destruction of herring by man is probably insignificant compared with that wrought by other natural agencies. Cod and ling, of which three and a half million were taken in Scotland in 1876, 
feed largely on herring, six or seven being often found in the stomach of a cod. These, it is thought, may consume twelve times as many herring as the four nations together. Gannets, of which 10,000 dwell on Ailsa Craig, must catch more herring than all the fishermen of Scotland; 'whales, porpoises, seals, codfish, dogfish, predaceous fish of every description, are constantly feeding on them from the moment of their birth. The shoals of herring in the ocean are always accompanied by flocks of gulls and other sea birds, which are continuously preying upon them; and it seems therefore no exaggeration to conclude that man does not destroy one herring for every fifty destroyed by other enemies. The destructive power of man therefore is insignificant, when it is compared with the destructive agencies which nature has created; and nothing that man has done, or is likely to do, has produced, or will probably produce, any appreciable effect on the number of herring in the open seas.'

On the east coast off Aberdeen, the fishery is now carried on in deeper seas, with larger boats than formerly; and though some inshore fishings on the west coast have diminished, the fishing in general has largely increased.

The substitution of lighter nets of cotton for the old hemp nets enables the same boats to carry five times the former extent of netting, and with the increase in the number and size of the fishing-buats, has raised the extent of the netting used by the Scotch herring fishers to a notable magnitude. 'There are more than 7,000 boats in Scotland fishing for herring. These boats must, in the aggregate, have nets 23,000,000 yards long, and certainly in the aggregate 230,000,000 square yards of netting. The Scotch 
herring nets would, in other words, reach in a continuous line for nearly 12,000 miles, and cover a superficial area of 70 square miles. They would go more than three times across the Atlantic, from Liverpool to New York, and cover more than one half of the Metropolis under the Metropolitan Board of Works.'

It is true that this vast amount of netting is not worked at the same place and time; but on many nights there are 1,500 boats fishing off the coast of Aberdeenshire. Their nets would reach six times across the North Sea.

The sprat or garvie fishery is also of some magnitude; 80 tons of garvies, worth 4,000l., are annually sent from Inverness alone, to London and other large markets, as food for the poorer classes.

The Commissioners recommended some minor regulations for the improvement of the inshore fishing; but that the gannets, rather than the fishermen, should be restricted. They considered general legislation for the herring fishery unnecessary and unadvisable.

To this report was appended a full and interesting account, by Frank Buckland, of the natural history of the herring and sprat.

These special inquiries did not interfere with the annual reports on the salmon fishery, in which various strange customs are noticed. In the estuary of the Eden in Cumberland, the salmon are taken by heave-nets and handnets, like gigantic shrimp-nets, the larger ones 19 feet, the smaller 6 feet wide. The fishermen were apt to quarrel for the best places on the shore, which, however', were chosen by a custom called ' mills.' 'A number of small hills of sand are made, according to the number of fishermen who want 
places, and are arranged in a circle. The last man who comes up is blindfolded, and set a short distance off, while each man chooses a lillock of sand, with one for the man blindfolded; the latter is then brought up, set in the centre of the circle of hills, the bandage taken off his eves, and he proceeds to kick down one of the hillocks. The man who chose that hillock has choice of position in the water, and the second, third, fourth, and so on, are chosen as the owners of the heaps alternately next to the one kicked down.

This rude lottery was capable of abuse, and the Inspectors were appealed to by the fishermen to settle their disputes.

Lectures and literary work went on during these years as heretofore.

'The Log-Book of a Fisherman and Zoologist' was published in 1875, collecting and enlarging articles on varied subjects.

In the same year, in addition to his usual contributions to 'Land and Water' and other papers, Frank Buckland undertook a new edition of 'White's Natural History of Selborne,' adding a store of original observations. To this Lord Selborne contributed a chapter on the Archæology of Selborne, and Mr. Delamotte some beautiful illustrations.

Frank Buckland was an ardent admirer of Gilbert White, with whom, notwithstanding the interval of a century, he had much in common; a like keen obserration of nature, and power of opening the eyes and ears of others to the wonders which daily surround us.

Did good Gilbert White, when lie watched the flight of 
birds in his quiet parsonage garden, noted their song, and marked the opening and close of flowers, think that his letters would be read with delight, and multiplied in successive editions a hundred years afterwards; or was he ail unconscious of the pleasure and profit he was storing up for succeeding generations?

In July 1875 Frank Buckland went to Windsor, at the request of Prince Christian, ' to examine into the plague of frogs,' and was presented to the Queen.

Adopting Nature's principle of 'Eat, and be eaten,' he advised to turn out the ducks to devour the frogs.

He made a report on the subject, with which the Queen expressed herself much pleased. In the following year the Queen visited his museum.

'May 13, 1876.-Her Majesty the Queen visited my Fish Musenm. Met her at the door and conducted her' right round the Museum, explaining salmon-breeding, casts of salmon, Prince Christian's pike, seal story, whale story, the big silurus, the big carp. Spoke also to the Empress of Germany, the Duke of Edinburgh, Sir Bartle Frere, and others. Professor Owen congratulated me on the appearance of the Museum.'

In 1876 one of the oldest home pets, 'my poor old Hag,' died, to the grief of her master, who showed his sincere sympathy in this account of his dumb friend:-

' Those of my friends, who know my working-room at Albany Street, will recollect that I always have attached to my staff" as "chamberlains" several monkeys. For the lnst seven years the "old Hag" and Tiny lave lived in a parrot's cage by the side of my fire, and in cold weather they were put into their night cage, and put before 
the fire till the morning. Last summer a lady asked me to take charge of her pet monkey, Jenny, offering me at the same time Jenny's large cage. Since the sumner the three monkeys have lived in my room in this palacelike crge.

'I am sorry to say there are now only two monkess in the cage, for it grieves me much to report that the "old Hag" has gone the way of all monkeys.

'A few months ago the Hag began to eat her tail, not an uncommon thing for monkeys to do when their health is failing; she gnawed away about two inches from the end of her tail. I tried to stop the progress of the disease, but in vain. At last I cured it for a while by giving her raw rumpsteak to eat. About three weeks ago the poor old thing's health failed again, and in spite of port wine and the best of nourishing food, she got weaker and weaker, till during the past few days she could not walkin fact, could hardly stand. When I came down on Sunday morning I could not see the Hag in the cage. John the page boy said she was in her box, but would not take her breakfast; so I got into the cage, and was heartily grieved to find the poor old Hag in a sitting attitude quite dead.

'The old Hag was a very remarkable monkey; for nearly twelve years she has been my constant companion, sitting close by my side in the corner of the cage, warming herself in the winter, and in summer asking me, in her own way, to put her and Tiny out in the sun.

"The life and adventures of "Hag and Tiny" in days gone by are fully recorded in my " Log-Book of a Fisherman and Zoologist." They used formerly to be allowed to run about the room loose; but one day, when I was playing 
with the Hag, she bit me in the right thumb, and this was just at the time when I was excessively busy with official work. I showed the old Hag the blood streaming from my hand, and said, "You bad old Hag!" The poor thing knew as well as possible that she had done me some mischief, for she looked at me in a pitiful way, and talked monkey-I have learned to talk monkey long ago-saying, "I am very sorry that I bit you ; it was an accident."

"The Hag had two distinct faces-I mean expressions. One was that of dolce far niente, when she was lying in front of the fire warming herself, after the manner of a cat. At this time her pretty brown eyes were always fixed on mine, and when writing, many an idea I have obtained from looking into the dear Hag's brilliant eyes.

'From having lived so long continually in my room, there was a sort of mutual understanding between us; and if ever an animal thought, it was the old Hag. It was purely the language of the eye, for I could tell from her look what she wanted; and I am pretty sure she could read my thoughts in her own way. When I was hard at work, and the room quite quiet, the Hag wore her face of contentment; when, however, she was enraged, she was quite a different monkey. She would bristle her hair up on the top and around her head, and all over her body, so that she looked twice as big as she really was; she would gape wide, open her mouth and show her sharp incisor teeth, looking the very picture of rage and fury. She would then fly on to the bars of the cage, and shake them tremendously, while she "rattle her whistle," as I called it, i.e. uttered her cry of defiance and rage, for she was a true, plucky little monkey. She was about the same size 
as an average-sized cat, only with a longer tail. For some unknown reason she had taken a most intense dislike to Mrs. Buckland's sister; if she only heard her voice she would begin to get in a rage, more than once she has pulled her dress nearly off her back, and often and often I have seen her caught by the hair by the Hag and hanging on to the cage like the pictures of Absalom suspended from the tree. The Hag, however, was greatest possible friends with Mrs. Buckland, who used frequently to take her out and nurse her of an evening. Mrs. Buckland can tame any animal in the world-ecce signum, myself. The Hag's perquisites for nuts and sweets were the coppers out of my coat pocket. On Sunday she had sixpenny worth of nuts and sweetstuff.

'Somehow or other the old Hag always knew when it was 1 o'clock. Regularly every day, about five minutes to 1 , she used to cry for her dinner; in fact, the cat's-meat man and Tiny and the Hag were as good as watches to me. Exactly at half-past 12 every day, I hear my cat's-meat man in the street calling "Meat;" if I don't hear him the parrot immediately commences to call "Meat, meat." Old grey poll parrot has been in my room much longer than the Hag, and can take off to a nicety the various cries of the monkeys. I have also a thrush whose song is very beantiful. The parrot is picking up the thrush's song nicely; he has as yet only got the first words of the thrush's song, viz., "knee-deep, knee-deep, knee-deep." Poll is now trying to imitate the bark of a little suricate which is running about the house.

'The monkeys' dinner consists of boiled potatoes, bronght up on a tin tray. The Hag and Tiny alwass 
dined together, one on either side of the tray, but poor Jenny never got a bit to eat till they were satisfied. Jenny knew all about this, and sat contentedly looking at the Hag and Tiny until her turn cane to have her meal, then she came down and dined by herself.

'The old Hag and Tiny were the greatest possible friends. I liare had Tiny about seven years; Mr. Bartiett brought her down in a money-bay from the 7oological Gardens for a dead monkey; but Mrs. Buckland, being an excellent nurse to animals, brought her round. Tiny always acknowledged the superior authority of the Hag, in the same sort of way a roung lady acknowledges the superiority of her chaperone. Tiny is always looking out for mischief, and when the Hag was sitting on the bar of the cage, she would pull the old Hag's tail, sharp like a bell-rope, and then look the other way, as if she had not done it. The old Hag would show her teeth at Tiny, as much as to say, "Don't sou do that again." On some occasions, however", Tiny went a little too far, and the Hag could not stand it any longer; would rush after her, and give her a jolly good whacking, pinching, and biting; I don't think, however, she leally hurt Tiny. An occasional, whacking from the Hag did Tiny good. If the Hag was taken out of the cage, 'liny would cry after her dreadfully; her cry is "whoa, whoa," a pretty plaintive musical note; and if she thought anyone was hurting the Hag, or teasing her, she would go perfectly mad with rage. I took particular care to observe what Tiny did when the Hag was dead; she evidently knew something had happened. Some vague idea of alarn had crossed her mind, for she walked up and down, looking in a puzzled manner at the Hag, and then at ure, as though 
she wanted to tind out by my looks what was the matter. The whole of Sunday Tiny was in a terrible state of nind, looking round and listening for every footstep upon the stairs, and watching the door. When John and myself went near her, she would fly at us immediately; she evidently thought we had done something to her old friend the Hag. She seems now quite to have forgotten all about it, except when I call, "Hag, Hag!" she then looks anxiously round the room. The only one thing that seriously alarmed the Hag and Tiny was a snake, dead or alive. The old Hag was excessively curious, and, when a parcel was brought in, she would watch and watch until she saw what was inside. The greatest fun I could have with the Hag and Tiny was to let them unpack a snake. I would put a snake into sereral coverings, and the monkeys would tear away the paper, thinking there was sweetstuff in the centre of the parcel. The moment they saw the snake they exhibited unmistakable signs of fear, getting to the top of the cage, and chattering at the snake. I have come to the conclusion the poor old thing died purely of old age. She must have been, I calculate, fourteen jears old; her coat the last two years has been getting quite silvery.

"My motto has been, "Love me, love my monkey." Those who knew my monkeys personally will, I am sure, be sorry that I have lost such a dear friend as my poor old Hag.'

A few months later he narrated the life and death of another of his pets, the reigning suricate.

'For the last eight months there has been running about the house, quite free and uncontrolled, my little Jeumy. My Jemmy is a zenick, or suricate. They are 
sometimes wrongfully called the prairie-dog, but he is neither dog, nor does he live on the prairie. Still, he has a wonderful voice, not at all unlike the barking of a dog. His general appearance much resembles a small ichneumon or mongoose, but to my mind he rather resembles a large rat, only that his nose is much more pointed, like a fox. When he is at home he lives in South Africa, and burrows in the sand like a rabbit. A friend of mine tells me that he has often disturbed colonies of them, and that they instantly bolt into their holes. Jemmy was very good at a mouse, either alive or dead. He was a greedy little rascal, breakfasting first with the servants, and twice upstairs afterwards. Whenever John brought up anything to eat, Jemmy was sure to follow him up for his share. He was excessively tame, but the only people he disliked were little children, and his delight was to bite their white legs. His pace was generally a canter, with his tail stretched out straight behind, and he was very fond of cantering upstairs barking in front of any person. Before he entered my room, he always stood at the door with one leg up like a pointer dog, and peeped into the room.

'People were very much struck with his intelligent appearance, his jet black eyes looking most amiable, and, at the same time, plaintive. He was so gentle in his disposition that I used to call him "poor little fellow," and he knew his name quite well, although I fancied he was somewhat deaf. He had long sharp claws on his forelegs, and would scratch at everything, particularly between the joints of the floor. The moment a newspaper was thrown on the floor, he immediately began scratching it to 
pieces. He would hunt for mice behind the books. He was a great friend of the dustmen, because they sometimes brought him mice. Being an animal that loves a hole, he was fond of getting into boots as they lay on the floor, and I have often had to shake Jemmy out of my boot before putting it on. Of the three cats in the house he was complete master. The cat's meat man conues almost to a minute, at half past twelve, and when the cats rushed to the area, Jemmy was there too. He would steal the meat from the cats. When he got near the cat and she began to show fight, he would back himself straight up, and putting his head down between his fore-legs, would be sure to have some of the meat. One cat was an especial favourite. John (the buttons) thinks it is because lie played with her from a kitten, and he would bite anyone who interfered with her. He would sit up before the fire on his hind-legs, and warm himself. When the fire was going down, he would get under the grate, and would suddenly scuttle out with his coat all on fire from a hot cinder having dropped on him.

' Besides his barking, Jemmy had another note, which sounded like a thrashing machine. He would make this noise when tickled, at which time he showed his teeth, but did not attempt to bite.

"When hungry he used to go to the kitchen to" the servants, and "quack, quack, quack," till he got something. He was not friends with the laughing jackass, who, whenever he came near, put up the crest and feather's on his head at him. I do not know which was most afraid of the other, the jackass of Jemmy, or Jemmy of the jackass. With Jenny and Tiny, the monkeys, he was an 
especial favourite. When any person touched Jemmy at the fire, the monkeys took his part, thinking someone would hurt him.

' On Thursday last, Jemmy was in the casting-room, when my secretary hearing a strange noise, turned round and saw Jemmy was on his back on the floor in a severe fit. He was taken upstairs to my studio, and I put his feet in hot water, slit his ear and gave him a dose of caloinel; in fact, I gave him every medical attention; but it was of no use, as he died on the following day. When the poor little fellow was struggling before the fire, Jenny and Tiny thought that their favourite was being injured by myself. They made frightful faces, desperately shook the bars of their cage, and almost cried with anger. These monkeys must have known that something serious was the matter with Jemmy, or they would not have made such a demonstration; in fact I never saw them so furious before. Even now, they have hardly forgiven me for supposed injuries I had done to Jemmy. Tiny especially misses him, and when I call "Jemmy, Jemmy, Jemmy," she looks anxiously about expecting to see Jemmy come round the corner.'

Besides scorpions and snakes, which, in their transit to Albany Street, caused anxiety to the Postal Department, a variety of beautiful natural objects were also sent there. Some of these Frank Buckland described in July 1877.

'Mr. L_L has been kind enough to send me a most lovely specimen of Vonus's slippers. 'These slippers are far more beautiful than anything yet turned out in the workshop of a London or Parisian ladies' bootmaker. 
'These beautiful specimens were not found in the wardrobe of any small-footed human beanty, but floating far out at sea, in the Mediterranean on the French coast. Each slipper is about an inch and a half in length, and half an inch in the widest part. They are of a lovely glass-like consistency, and in certain lights resplendent like jellyfish. They are the shape of a handsome shoe; the edge of the shoe projects in a very ornamental dentated margin, and the toe part is highly ornamented, as if with embroidery insertion. It is one of the pterapoda or wingfooted molluses, so called from the fin-like lobes which project from the sides, and are evidently analogous to the similar organs in some of the sea-snails. These appendages are used almost like wings, the creature flapping its way vigorously through the water, just as a butterfly urges its devious course throngh the air.

'I have also received two magnificent specimens of the golden beetle from India. It is about the size of a very large lady-bird, and certainly the most beautiful insect I ever examined. Its appearance is that of a small, golden tortoise, delicately set under a transparent shield of thin horn or pale tortoiseshell. The colours are a most beautiful emerald and gold mixed; so beautiful that a lady has borrowed the beetles from me for her jeweller, who has made an enamel model of them, forming most lovely ornaments.

'If our friends would pay more attention to the beautiful works of the Creator, they would, I think, derive more real pleasure than from the contemplation of the works of man, all of which I consider far inferior to Nature's own design and handiwork.' 
Humbler and commoner insects also attracted his attention.

'Flies,' he wrote, 'must have a wonderful power of scent. Let the reader try the experiment of putting down a bit of stinking meat in an open place or on a window-sill, where no flies are about; in a very short time, if I mistake not, the blue-bottles will begin to put in an appearance. Flies are most useful as scavengers, inasmuch as they lay their eggs in decaying animal substances; and most interesting it is to watch a fly lay her eggs. These egors hatch out in an amazingly short time, and the gentles very soon eat up the substance upon which they are deposited. It is said, in fact, that the produce of two blue-bottle flies would eat up a dead horse quicker than one lion. The elephant is such a gigantic and powerful animal that he has few animate enemies. The greatest enemies to elephants in their wild state are flies; the elephant has no knowledge of surgery, and the fly-blows are the death of him. I lately heard of an ingenious plan, where flies were made subservient to the wants of man. A poisoned rat had crawled under the floor of a very smart dining-room, and had died there. The room in consequence became uninhabitable for a time. All the boards of the room were about to be removed, when somebody suggested that a blue-bottle fly should be turned out. Mr. Blue-bottle hunted about the room for some time; at last he lighted upon a certain spot on the floor; the single board was removed, and there, sure enough, was the dead rat. The blue-bottle had found him out by means of the scent coming up through the crack in the boards. 
'I was lately watching a sunbeam; the shutters were partially closed, and the sun's rays came into the room through a small hole only. Among the sunbeans were playing some six or eight common house-flies; they yenerally flew in circles, and one might imagine them to be eagles soaring among the clonds, and looking for their prey. I once saw an eagle so bigh in the air that he did not look larger than one of these flies. The curious part of this race of the flies was the funny way in which every now and then they seemed to attack each other, rushing together quickly and instantly separating. All this was done with such rapidity that the eye could hardly follow their movements. They also every now and then tumbled, or pretended to tumble, after the manner of rooks falling in the air when wet weather is coming on.

'Those who are fond of natural histors, and of watching the habits and actions of living creatures, need not go out of their own rooms to find occupation; they will find plenty of interest in watching those hitherto neglected, because so common iusects, house and blue-bottle flies.'

Frank Buckland's quick observant ejes were alwars watching the babits of living creatures, and found entertainment alike in the house, in the country, or in the bumours of the London streets.

In August he described his 'experiences of the Iondon season from the 'bus-top ':-

'I ride generally down to the Fisheries Office on the top of an omnibus. The top of an omnibus is a grand place. One can write notes there, think there, smoke there, get the fresh air there, get wet through there. I like to 
get wet through, and the harder it rains or blows the more I enjoy my ride on the 'bus-top.

"From the 'bus-top I see so many pictures of real life, that a thought has come across me to "paper" some of the things I have seen and heard. London streets and the people in them are in fact a moving panorama of real life; besides which, it is fine training for one's faculties of observation and inquiry. Some of the busmen often say funny things, and I instantly book them. "Wo-o, hold hard," I said the other day, descending from a "yellow twopenny," at the corner of Westminster Bridge. "Stop the prehanner, Jim; here's a gent as wants to get down," shouted the conductor.

'On another occasion the 'bus changed horses in the middle of the street; the ostler was somewhat slow; the conductor cried out, "Look alive, father! here's Jack acoming." So I changed my place from the knifeboard to look at "Father," a disagreeable old man, over seventy, from the look of him; but such a coachman! He drove his pair of screws splendidly. A brougham got in his way, ind did he not abuse the "tea-and-kettle servant," that's all! The words "Jack's a-coming" had put him out. Jack (I found out by looking) was a young man who drove the 'bus that followed "Father's" 'bus, and who, I suppose, hunted the old fellow to put him out.

'On another occasion I heard the 'bus driver and a passenger discussing somebody who was not a favourite. "Bless ye," said the driver, "I could make a better man than him out of old tea-leaves."

"Will my reader's kindly notice, that if they see one thing of a peculiar kind they are certain to see its ditto, 
if not that day, then very soon afterwards. I saw not very long ago a little boy at the corner of Vigo Street. He was the most extraordinary bandy-legged and deformedfooted little urchin I ever saw, his feet seemed put on the wrong way, like the Indians put on their horse-shoes the wrong way to make their pursuers "run to heel." My first idea was, what an anatomical preparation I could make out of that boy, or, at least, I should like to cast him.

' In Parliament Street, not ten minutes afterwards, I saw a cripple on a board, shoving himself along on a bit of board with paddles made out of sticks. The cripple would have made a fine companion picture to the bandy-legged boy.

'Another day, at Regent Circus, Oxford Street, from the 'bus-top I saw a girl with an immense stock of fiery red hair. I took out my note-book, and timed the girl. I saw another red-headed girl opposite Negretti and Zambra's shop; a second near the Life Insurance Office, Regent Street, and a third at, the corner of Waterloo Place, by the Athenæum. "So ho," I said, "my theories are right, three red-headed girls in seven minutes!" All the red-headed girls seemed to have come out together the same day. I looked out four subsequent days, and did not see a single red-headed girl.

' There is an extraordinary old woman, that I see almost daily from the 'bus-top, somewhere between Charing Cross and the bookseller's shop at the corner of Parlianent Street. When she was a baby, somebody must have tied her head and heels together with a bit of string, just as they make the crooks of walking-sticks. She is a very 
old woman now, and I am afraid very poor; her spine seems to be in the figure of $\mathrm{S}$, and she carries her head on about the level of her hip. I must find out the history of this old woman.

' The night the great Peabody was buried in Westminster Abbey, I heard the bell toll as I was sitting at my desk writing very busily. Shortly afterwards, I saw an old woman wrapped up in a shabby cloak, and apparently warm, though the night was cold, at the corner of a publichouse opposite the Home Office. She was selling baked chestnuts; and a bright charcoal fire burning in what, I should think, had once been a rushlight case, helped to keep the poor old soul warm. Two shoeblack boys were standing near her, dressed in red-baize jackets. One of them-an intelligent open-faced English lad-had a penny evening paper in his hand, and he was reading a paragraph, round which ominous black lines were printed. I looked at the paper as I passed; the paragraph was headed, "Death of Peabody, the Poor Man's Friend." I stopped and looked, not intruding on the scene, of course. The boy went on reading; the poor old woman folded her arms, and as the boy went on reading, she looked up through her old worn spectacles, and said, "Bless him, and God bless him for his kindness to us poor." Artists, where are your eyes? Why do you not look about you? What grand natural pictures you would see if you would only deign to look at what is before you! I ask my friends, the public, if a greater compliment to Peabody's memory could be possibly paid than a picture embodying the scene I have attempted to describe in words.

'I saw a funny scene one day that made me roar' with 
laughter. I like to laugh out, I don't often get a chance, It was a drunken man fighting a block of Wenham Lake ice. I pass the Wenham Lake ice-shop at Charing Cross twice daily. One day I saw a sturdy fellow of the goods-pcrter class, on the other side of the road by the Drummonds' Bank door, with a huge block of ice on his head. He was a little drunk, and when he was in the middle of cne of his rolls, like an ironclad in mid-ocean, the ice slipped off his shoulders and slipped on the pavement. The fellow stopped, shook his fist at the ice, and, I should think, swore considerably at it; at last he went up and kicked it with his great hob-nailed boots. This, of course, made the ice slip away; the fool of a man then followed it, uttering profane words, and then down he fell with his nose on the ice. This made him more furious still, and he punched the ice as though it was a man's head. Some good-natured fellow offered to help him put the ice-block on his shoulders; but, of course, it instantly came down with a crash. The man was too drunk to hold it up. As the 'bus moved off, the last, thing I saw was the ice-porter pitching into the poor man, who had offered to assist him. This is all I know; the next dar, as I passed the place, the ice. porter, and all were gone.

'Another curious scene, taken from life. A cab-horse in a four-wheeler at the stand by Palace Iard; the cabhorse fast asleep with his head hanging down; the cabman also fast asleep, leaning against the horse. The cabhorse (I suppose in his sleep) kicks the man ; the cabman instantly wakes, and kicks the cab-horse in return. "You brute," he said, "I can kick as well as you can," and then they went on at it again-the cab-horse and the cabman 
kick for kick for a minute or so, till at last I settled the dispute by saying, "Hi! cabby, four-wheeler, go to so-and-so." "Right you are," said the man, and we all three trundled off, as though nothing particular had happened.

'I must say a few words about an old acquaintance"Kate, the flower woman." She is a good type of the many industrious London poor, who get a precarious living by flower-selling in the streets of this vast metropolis. Mrs. O'Brian-Kate-is an Irish woman. Eight years ago her husband ran away to America, and left her to shift for herself and her two children, a boy of ten and a girl of eight. For eight long years this industrious woman has sold flowers at the bottom of Windmill Street. She has given me an outline of her business. She goes to Covent Garden market to buy flowers at 4 o'clock in the summer, and 5 in the winter. Camellias cost $6 s$. per dozen, and white roses, 3s.; ferns, $1 s$. a bunch, and doubles (whatever they may be), $6 d$. a dozen. On her return from market, it takes till 2 o'clock to make up her flowers into little bouquets, which she sells at $4 d$. or $6 d$. each. She has great taste in arranging the colours of her flowers. She comes out to sell at 3 in the afternoon, and stays out sometimes as late as 12 o'clock at night, holding the flower-basket all the time on her arm. 'The profit for these nine hours is $1 s$., sometimes $1 s .6 d$., and on a very good night, $2 s$. She pays $3 s$. $3 d$. a week for lodgings.

'An immense crowd at the north-west cormer of St. Martin's Church, all the people gazing intently upwards to the steeple. I got off the 'bus, of course, to see "what 
was up," and Mr. 'Busman and Conductor looked as though they would have liked to have stayed also, only the "Bobby " came up and told them to "move on." I looked and looked, but could see nothing, and my eyes are not particularly dull. At last, perched up high-very high-on a ledge of the steeple, I saw a poor little canarybird all by himself. I fancy the canary-bird was flattered by the attendance of the crowd, for he was evidently addressing them with his "Tweet, tweet." He looked like a public orator in a swallowtail coat addressing the multitude upon the rights of men or women, or animals if you please, and especially the rights of canary-birds, but all he said, or seemed to say (for I was too far below to hear him), was "Tweet, tweet. Where am I? Do tell me how to get home. I know my kind mistress is crying for me. She left the cage-door open, and I, like a fool, thought 'to better myself'; and here I am on the top of St. Martin's steeple, and I am frightfully hungry, and can't find any bird-seed on the steeple; and what a pack of fools you gaping, wingless idiots down in the street below me are. Now I'm off. Here goes." So the canarybird, that had attracted a larger audience than the Prime Minister or the Archbishop of Canterbury could command, opened his wings and flew away. The crowd dispersed. I took the next 'bus, and wished, when I got to the office, that I could get an old knowing salmon on to the top of St. Martin's steeple, and make him give his own ideas as to how the Salmon Acts affect his interests.'

While farmers and hungry Christmas folk were pummelling the fat sides of beasts at the Cattle Show, it was Frank Buckland's annual custom to visit the penny shows 
which congregate outside, to him far more attractive, in their oddity and variety, than the obesity within. In December 1877, he thus described his annual visit:-

'The Cattle Show at Islington is fully appreciated by naturalists, inasmuch as it forms a nucleus for the coming together of the many penny and twopenny natural history shows which, I am sorry to say, are not so numerous as in former days. The showman's business is a business per se. It is not to be wondered that the showman has to exhibit much of the "gift of the gab" to draw in customers to his show, as the more declamatory the orator, and the louder his voice, the more likely is his place to fill.

"We used to read at school, "Natura hominum novitatis. avida," that is to say, everybody likes novelties, and this is the secret of the success of all shows.

'An experienced showman has informed me that nothing is easier than to get up a show. It is only necessary to build a simple wall, make a speech about the wall, saying you must not look over, and everybody immediately wants to look over the wall, and will pay for the privilege of so doing. In the middle of the Cattle Show week I went my usual rounds of the exhibitions outside the Cattle Show, with my friend Mr. Bartlett. These penny showmen now know both of us by sight pretty well. On the whole, the shows of this year were fairly good. I have before described Fatima, the bodyless and legless girl lately exhibited in Tottenham Court Road, and about the disposal of whose lower bodily half there was so much dispute. I have since obtained some excellent evidence that the aforesaid Fatima has really legs and feet. I passed over the road to a public-house opposite Fatima's show, and when dis- 
cussing with the landlord the cleverness of the exhibition, le assured me that Fatima had really arms and legs. He was quite positive of this fact, because every evening after the exhibition was closed Fatima ran across to his bar for the supper beer. Fatima seems to have been such a profitable exhibition, that there were two Fatimas outside the Cattle Show at Islington, namely, "Zaara, the living hodyless girl," and "Zariffa, the trunkless lady." The compliment. paid to both these ladies were extraordinary.

"Zariffa was "the talk of the Continent," "the amazement of thousands," and had "been visited by all the crown-ed "edds of Europe." It is a curious fact (if we believe the showman) that the "crown-ed 'edds of Europe" have nothing else to do, but to spend their time gazing in admiration at giants, fat women, and at other monstrosities and freaks of nature, living and dead.

'Zariffa was, like Fatima, apparently bisected; the trick is optical, and arranged by looking-glasses. Zariffa was a handsome, dark-haired, dark-eyed girl, always smiling and laughing. Zaara was a fair-haired girl, stupid, sleeps, and yawning. Next door to Zaara there was a fried-fish shop. Fried fish had been done away with for the time, and outside was a flaming picture, with plenty of smoke and streams of blood, representing the "Turkish Atrocities." "The Wild Man of the Woods," besides many other interesting and important and historical personages, were to be seen inside the show for the large sum of one pennr. A loud-sounding gong was the means used to attract visitors to the Atrocities. The proprietor of the "wild man "was jealous of too many people entering the portals of the bodyless woman, so says he to his comrade, "Sound the 
gong, Jim. Bill's doing all the business." The gong not proving sufficiently attractive, another ruse was resorted to, with which I was mightily pleased. The showman suddenly appeared before the door of the show with a carter's huge whip, threw his arms about as if to prevent something or somebody coming out of the show. "Keep him back! don't let him come out!" he cried, as he stood with his shoulders to the door, while strange yells, and the usual penny-show cry of wild men issued from inside. According to the showman's account, the wild man had tried to make his escape, and he announced that, after he had again been properly secured, the public would be admitted to examine him. This announcement immediately fetched Mr. Bartlett and myself, who paid the whole price of one roomful in order to get a private view of the wild man aforesaid. The moment we entered the stuffy, pokey little fish-shop, a mite of a girl, dressed in a very old shabby tinselled coloured gown, began to explain the waxworks, which formed the principal part of this show. She gabbled over the task of explanation at a most tremendous rate. Her waxworks consisted of a lady all in black with very long hair, and glassy, staring eyes; several wax figures, male and female, which might have been shown as anybody; a figure of a very thin old man, and a human skeleton in a cupboard. The child's gabble was something in this way: "Ladies and gentlemen, this is the most interesting exhibition in the 'ole of the Cattle Show, as you will perceive from the figures outside. It have been visited by 6,248 people, and they have all expressed their satisfaction. This," pointing to the wax figure in black, "is the Turkish atrocity. She 
vas a lady of rank, and one day when she vent to church, they cut her in two halves with a sharp sword, and took one half of her to one side of the church, and the tother half to the other. This is a hold man as starved hisself to death in Lambeth. He was a miser, and after his death they found a bag of money under his 'ead. These other is all the best murderers as has been known to the public for the last three years. This is the skeleton of Rosina Watson, who throwed herself over Waterloo Bridge. She have three hundred and sixty-five bones in her body, the same as there is days in the year." This sharp-faced bright-eyed little street Arab finished her oration thus"I have been privileged of going round the noble company for coppers, and I hope the gentlemen will patronise me and this 'ere show." We then asked for the wild man, who was behind a curtain, which occasionally moved in a mysterious manner. It appeared that the wild man had been peeping through the curtain at us all the time, and, when the girl had done speaking, he rushed out and shook me by the hand, and claimed me as an old friend, who had " papered" (or written about) him for these last three Cattle Show year's. Bartlett, I, and the wild man immediately fraternised. The wild man is a very ugly nigger, tremendously stroug, with a huge mouth, white teeth, and awfullooking eyes. He gets his living by making hideous faces - his gorilla face is capital-and by his extraordinary voice, which is more like the bellowing of a bull than anything else; hence I believe his professional sobriquet of "Leather mouth Jemmiy." The other accomplishments of the wild man are, I believe, that of biting off the hends of live rats and eating their bodies, dnncing on red-hot irons, 
and drinking spoonfuls of lighted naphtha; so that altogether he is a very accomplished wild man.

'In the next-door show was a "feather-bodied woman, half bird, half fish." "She is alive, alive, alive." A greater untruth could not have been told; nevertheless we entered with the crowd. The history of the remarkable lady was, that she was found sitting on a desolate rock, in the middle of Australia; she was then half dead and half alive. She was discovered by an American traveller, who took her to America, where she lived for fifteen months. The explanation over, the fellow opened a very rickety old box, and displayed a hideous, faded wax figure, consisting of a creature with the tail made of a hake's skin, a feathercovered body, the features of a monster, and the beak of an eagle. He would not give us a minute of time to examine, but slammed to the box with "The exhibition is now concluded, and thank you, ladies and gentlemen, for your patronage."

"In the next show was exhibited the "Irish Prize Wonder," a hideous fat woman, who could hardly waddle. This is a new fat woman, for I have known nearly all the fat women, but the picture outside is the same that has served for exhibition for many previous fat women. The weight of this "Irish wonder" was said to be forty stone -that is, $560 \mathrm{lb}$. The "Indescribable Female" and the "Indiarubber Man" was the next show we went to. According to the showman's account, the "Indescribable Female " had escaped for refuge to a cave, where the lime encrusted all round her and "kivered up her bones." After a long story, very well told, he brought out the dried body of a child about five years old, minus one leg and 
one arm. Common mortar had been placed upon it here and there to represent the lime from the cave. The "Indiarubber Man" was a gymnast, who did everything except carry his body in the position it was originally intended it should assume.

"Those who do not condescend to go into what I call the "Poor man's market," especially on a Saturday night in the streets of London, can have no idea what ingenuity and perseverance is shown by these "miserables" (but yet I trust happy "miserables") to procure a subsistence. Thus, outside the Cattle Show, was a noble-looking old fellow who was selling "The Queen for a penny." I bought a pocketful of statues representing Her Most Gracious Majesty. The statue stands on a black pedestal with black velvet lining, and is covered with an oval glass about two inches high; it is really a very neat affair. I have examined the statue. The Queen is made of thin wax, but really the statue is not bad at all. The old man also bad statues of Napoleon, the Sultan, the Emperor of Germany, \&c. all at one penny. Who would not be a potentate at the price?

' Some poor ragged urchins were selling penny cards, called the Christmas puzzle. On the card was represented a big oak tree, and three men under the tree, with guns. The puzzle is to find a bird and a dog, made by the branches of the tree. This is certainly a puzzle, but, when made out, a pheasant and a setter-dog are quite apparent in outline among the branches of the oak.

" "A roasting-jack, ol" a toast-maker, for a penny," is the cry of a poor woman, whose lusband is now toiling at home to make the goods for his lialf-starved wife to sell. 
A "water magnifying glass for a penny." This is a bulb of thin glass full of clear water. It has a splendid magnifying power. The "Old Obadiah and the young Obadiah" for two pence; two tin figures sitting on a quasivelocipede, two wheels with half a bullet between the wheels. These figures do very funny things, and you can't upset the riders. The weight is put exactly in the right place. I believe the Moncreiff guns are mounted exactly on the principle of "the two Obadiahs."

'At the last year's Cattle Show I bought a real telephone for a penny. It consisted of two broad rings of tin, covered over with dried parchment or dried drum-b]adder, like a drumhead. A length, some six or eight yards, of cotton, formed a communication between the two parchments, and conveyed the sound of whispering into the hollow of the parchment ring.

"I confess I like the "cheap jacks," the "wild beast shows," the "talking fishes," the "elephant horses," the "edible dogs," the "monster pigs, dwarfs, and giants," the "living skeletons," the "indiarubber dogs," the brass bands, the clowns, the gongs, the row, the chaff, the true Cockney "argot," i.e. provincialism, often exceedingly clever. So "A Merry Christmas and a Happy New Year" to the poor showmen, and good luck to their wondrons exhibits, the inspection of which has afforded me, and doubtless thousands of visitors, great amusement and fun.' 


\section{CHAPTER XIV.}

SEA FISHERIES, BIRD MIGRATIONS, ETC. : 1878.

IN 1878 Frank Buckland and Mr. Walpole were appointed Commissioners to inquire into the condition of the sea fisheries of England and Wales, which contribute so largely to the food of the people.

Above a hundred million soles are yearly sold in the London market alone, with fifty million plaice and whiting, and ten million eels, besides other fish.

The inquiry lasted from March to December 1878, and was resumed in 1879, and extended to the Isle of Man in August 1879, the Commissioners' report being presented in September 1879.

The inquiry proved the almost illimitable wealth of our sea fisheries, whose conditions are contrasted to those of the salmon fishery. The salmon fishery, confined to the rivers, is dependent on freedom of passage, and is capable of extinction. The ocean fishery is so vast, that man can but little affect it. No regulations were found needful for the protection of sea-fish, but only for the prevention of disputes among the fishermen ; and, notwithstanding the vast quantity of fish annually caught, there was no evidence of a falling off of the supply.

To this report Frank Buckland appended a history of 
British fish used as food, with observations on the bed of the ocean, which is their home; and on their food, growth, structure, and migration.

The editing of White's ' Natural History of Selborne,' in 1875 , with its varied original notes, liad directed Frank Buckland's attention especially to the habits of birds. In 1877 and 1878 a series of papers appeared in 'Land and Water' and the 'Daily News,' containing observations he had made or collected upon the vernal and autumnal migrations of birds. By these papers he designed not only to record facts of natural history, but to encourage in others the like habits of observation. Few dwellers in London (except the bird-catchers) are aware of the number and variety of birds, which haunt the neighbouring woods and fields, and offer a constant source of interest, to those who would study their habits, or listen to their song.

'March.-The annual migration of birds to this countr'y has now begun. The two first arrivals have been the wheateal and the chiff-chaff; these come from the South of France. The wheatear locates himself on heaths and common lands, his favourite resort on arrival being the South Downs. According to some, the name of wheatear is derived from the plumage of this bird, which in the spring carries a white tnft on either side of the head. It has been said that the females come a fortnight before the males; but Mr. Davy, the well-known birddealer, has always found that the hens arrive at the same time as the cocks. The London bird-catchers take the wheatear by a meal-worm or maggot in a robin trap, which is placed on a small hillock, as the habit of the bird is to fly from hillock to hillock. The wheatear is splendid 
eating; and, before the new Act, great number's were caught about Eastbourne, by snares made of horsehair. Before the days of railways they were sent pickled to London. The wheatear feeds on small beetles and flies, which are found on downs where wild thyme is abundant. They breed in the month of May, in the neighbourhood of quarries. The nest is a simply made. structure, and the egors are light blue.

'The chiff-chaff, a merry little bird, may be seen and heard on sharp, frosty mornings, sitting in the top of a willow, the frost not seeming to take any effect on him. The name is taken from the song "Chiff-chaff, chiff-chaff." The bird-catchers call them the "chinkey-chank." They feed on minute insects, and are among the earliest to arrive and last to leave, sometimes staying till November, though usually leaving in October. The nest of these birds is a little oven-shaped structure, and in some parts these birds are known as "oven-builders." They are found all over England.

'Coming up lately from Bridgewater by the Great Western, I kept a good look-out for birds. Starlings were. in flocks. The jackdaws were making a great noise, and very busy getting their nests ready, about the towers of Exeter Cathedral. All the way along the line from Taunton to Paddington the rooks were sitting on the tops of the trees, and in many cases the hens were sitting on their eggs. The last rookery I saw was in the Marylebone Road, where there were sixteen nests.

'There is round the base of the rook's bill a white skin. It is said by some that the feathers have been worn off on this part by digging in the ground. My opinion is that it 
is naturally devoid of feathers, though it is curious to observe that the young rooks have feathers at the base of the bill, which afterwards disappear. The ravens and jackdaws retain the feather's at the base of the bill all their lives.

'Noles and rooks are great devourers of wireworms. I obtained this information from a merchant in gingerbread-nuts, at Harting, Sussex, who was a great anthority on moles. He tends cows for a contractor, who keeps a great many of these animals to make concentrated milk for the nary. The moles are of great service; they eat up the worms which eat the grass, and wherever the moles have been, afterwards the grass grows luxuriantly. When the moles have eaten all the grubs and worms in one place, they migrate to another, and repeat their gratuitous work. The grass where the moles have been is always the best for cows. The rooks also help to keep down the wireworms. I think it would puzzle some philosophers, to explain how the supply of milk to the nary depended upon the abundance or absence of rooks and moles.

'Dormice, I learn, are very abundant in Lord Portsmouth's woods at Eggesford, Devon. The woodmen working in the plantations often find their nests; they are composed of round balls made of grass and moss, and are attached to twigs of low bushes; they much resemble the wren's nest, and are about the size of a cricketball. In very hard weather the door is shut up entirely; they sleep four or five months during the year. Just now the dormice are waking up. If a dormant mouse is found, and is gradually thawed, either by the hand or by 
the fire, he gives a sharp squeak at the moment of awakening.

'As the spring months come on, great opportunities for observing living creatures will be given to naturalists, both in town and country.

'My laughing jackass has woke up considerably this last week, and he now laughs loudly about every halfhour; the noise he makes can be heard at a great distance.

'April.-Mr. Davy has brought me news of the arrivals of British migratory birds for the spring. As regards the nightingale, he informs me that two fine males were taken in Surrey on April 7, and several more on the 9th: this is eight days earlier than the usual arrival of the nightingale. About April 15 the nightingale's song will be heard in any year, in a suitable place, let the weather be what it will. Those who wish to test this should go to the neighbourhood of Hampstead, where at the setting of the sun, or early morning, nightingales may at this date almost certainly be heard. It is a curious fact, that as soon as the male nightingale arrives, he settles down at once in a suitable place for nesting, and immediately commences his song: this is called by the catchers being "laired," i.e. taken to a "lair," and the birds are to be caught in the immediate locality of their lair, any day afterwards during the season. Johnson defines "lair" to mean "the couch of a boar or wild beast."

Out of the ground uprose,

As from his lair, the wild beast, where he rrends.

But range the forest by the silver side

Of some cool stream, where nature shall provide

Green grass and fattening clover for your fare, And mossy caverns for your noontide lair. 
'The nightingale is a very simple-minded bird, and easily taken with a bait of common maggots or meal worms. If a nightingale is caught off his lair before the hens arrive, the place is frequently taken by another male within four and twenty hours; showing that the place they hare chosen is suitable to their nature. If two male nightingales meet on the same lair, a fight ensues, and one beats the other off. The males, as a rule, arrive eight or ten days before the females, which seems to indicate a provision of nature, that the husband shall find a home for his wife. The nest of the nightingale is principally composed of dried oak leaves and grass, and as a rule the pair produce five young ones. If they rear these young ones, they do not breed again. If the nest is taken, they generally go to nest the second time.

' Jackdaws and some other birds resemble the nightingales in this respect; if young jackdaws are left in the nest till they are a fortnight old, the old ones will not breed again that year. In many parts of the country where jackdaws abound, men go round with ladders on a special day and take the young birds from the nests; they are very good eating, cooked like young rooks. Jackdaws, when they have young, are much in the habit of robbing the nests of common sparrows of their young, to feed their own young ones: the sparrows have no means of protecting themselves, but the call of fear, for which the jackdaw does not care. If kept in captivity jackdarvs are very fond of small birds, dead or alive, and would nip a sparrow's head off in a moment.

'Among other arrivals within the last fortnight are the titlarks or the pipits (Anthus arboreus); they have come 
in large numbers; these, like the nightingale, "lair" immediately on their arrival. The titlark is sought for for improving the song of canaries and linnets. Nestling linnets are reared in the company of the titlark; the titlark has a song which is called "wheeting and fearing," and the linnet being a bird which takes a song very freely, soon learns to "wheet and fear" from the titlark. These trained birds are called "toy linnets" because they have an artificial song.

'Blackcaps have also arrived, and may be heard singing in tolerable quantities round London: these differ from the nightingale and titlark, inasmuch as the cocks and hens arrive at the same time.

'On first arriving they frequent the woods, and feed upon the ivy, of which they are very fond: in the autumn they play havoc among the currants and raspberries. The blackcap's song resembles, and is often mistaken for, that of the nightingale, and for this reason it is called the Norfolk, or mock nightingale. The nest of the blackcap is a very simple, rough nest, like that of the larger and lesser whitethroat. The male blackcap takes his turn at sitting, and will allow himself to be taken off the nest.

'All migratory birds appear to be found in the suburbs, or within a radius of ten miles of London, earlier than in any other part of the country. Londoners, therefore, have no excuse for not knowing the notes of birds, having every opportunity of listening to their song.

'September. - While the inhabitants of this great city are fast asleep, during the dark nights that occur generally about this period of September, many wonderful events 
are going on high up in the air, far above our heads. Of the nature and cause of these phenomena the general public are little aware. The noises proceeding from the numerous creatures, that are passing over our towns in mid-air, during the darkness of the night, would in former days have probably been put down to the supernatural agency of ghosts and goblins. Observation, however, has taught us that the mysterious forms, shadows and cries proceed from flocks of migratory birds, passing from one part of the earth's surface to another. More especially when the clear and frosty nights come on, may be heard in the sky the rush of the wings, and the wild cries of various water-bircls, such as wild duck, wild geese and other water-fowl, as they are passing from the northern to the more southern regions. Previous to speaking of the general migration of the northern water-fowl, we propose to notice the effect of the weather, which has occurred lately upon the smaller "soft meat" - that is, "insect-eating" birds. The late gales of wind and cold nights have dispersed and destroyed the insect food, such as moths, beetles, flies, caterpillars, \&c., upon which these birds fatten previously to their departure to spend the winter in more southern climates than our own. The late winds have also made havoc on the soft dead-ripe fruit-such as pears, plums, elder-berries, nightshade-berries, \&c.-upon which some of these birds feed. These two causes have induced many of our migratory birds to leave us before their usual time. The birds that have already left this country are as follows: Swift, nightingale, grasshopper warbler, sedge warbler, reed warbler, wood wren, garden warbler, wryneck, cuckoo. The turtle dove and common shrike have also left. 
The birds that are now fast taking their departure are as follows: Redstart, whinchat, wheatear, blackcap, whitethroat, chiff-chaff, willow-wren, yellow wagtail, tree pipit, meadow pipit, goat-sucker. During the past summer insect life has been very scarce, but, nevertheless, this fact has had no perceptible effect upon the numbers or breeding of these birds.

'At the same time that the above-mentioned birds are shifting their habitation, others are beginning to arrive from the far north. These are the missel thrush, fieldfare, redwing, woodlark, song thrush, blackbird, snow bunting, bramble finch, siskin, twite, and redpole, \&c. The nightshade-berries and blackberries are very plentiful this year, and bullfinches are feeding upon them in the lanes and hedges. Kingfishers are very abundant this autumn, and may now be seen about the brooks, ponds, and lakes in the neighbourhood of London. This is the time of year that these beautiful birds take their flight from their breeding places and fishbone-made nests in the holes of water-side banks. A kingfisher was lately seen on the Serpentine, and it is not at all improbable that when the parks are quiet, and people are not moving about, they may bo observed about the Kensington Gardens waters, at the northern end of the Serpentine. A great many kingfishers are at this time of year taken by means of the flue net. This is a net of light structure, suspended across brooks; in their rapid flight the birds do not see the nets, and get caught in the meshes. When the woodcocks are migrating to this country from Norway, considerable numbers are caught in this way, by light nets suspended in the line of their flight. The reasons that prompt the 
migratory British birds to venture over vast tracks of land, and over large seas, knowing, as they certainly do, the proper times for their passage, when to come and when to go, are by no means clear. Nor indeed has it been ascertained for a certainty to what countries they resort during the winter months; it is well known, however, that they go gradually southwards to the French, Spanish, and Italian shores of the Mediterranean. In some instances they cross the Mediterranean Sea to Egypt and the shores of Northern Africa; some go even as far as Central Africa.

'When these birds are on their perilous journeys of so many hundred miles, fogs and adverse winds frequently cause great destruction among them. Not very long ago large numbers of British migratory birds were found floating in the sea, dead, off the Eddystone Lighthouse. It is probable that during their night journey from the Devonshire shores a fog overtook them, and that the bright light proceeding from the lantern of the lighthouse attracted them, and so stupefied them that they dashed themselves against the thick glass, and were killed in large numbers. The fishermen who trawl for turbot, soles, skate, \&uc., on the Varne and Ridge banks between Dover and Calais, not unfrequently hear the sound of flocks of migratory birds flying overhead.

'The speed at which birds can go, when on their migratory flight, has been noticed. Quails are said to accomplish a hundred and fifty miles in a night, and undigested African seeds and plants have been found in the crops of these birds when they reach the French coast. Ducks are reported to be able to fly fifteen huudred miles 
at one flight, and the pace of the swallow and martin is put down at about nine hundred miles in twenty-four hours. Linnets and other seed-eating birds have been known to settle on the masts and ligging of ships far away from land out at sea. They will take their night's rest on the rigging, and, when leaving the ship, know exactly in which direction to continue their flight. It is said, that the migration of birds will foretell severe weather, and it is well known by the bird-catchers, that when the larks and other northern birds appear, snow and hard weather will follow the flight. These warnings of migratory birds, though apparently insignificant, may be of vast political and even national importance. If the Emperor Napoleon, when on the road to Moscow with his army in 1811, had condescended to observe the flights of storks and cranes passing over his fated battalions, subsequent events in the politics of Europe might have been very different. These storks and cranes knew of the coming on of a great and terrible winter, the birds liastened towards the south, Napoleon and his army towards the north.

'October.-Most of the northern birds due in the middle of October have arrived. All the summer migrants have gone except a few house swallows. The London bird-catchers have lately had large takes of the brown linnet, common redpole, greenfinches, yellowhammers, siskins, goldfinches, and mountain or tree-sparrows. The flights of birds arriving from the north are as follows:Hawfinches, goldfinches, chaffinches, siskins, mountain sparrows, twites, brambling, bullfinches, brown linnets, woodlarks, redwings, blackbirds, thrushes, and stony redpo es. The stony redpole has skipped these coasts for the 
last two or three years, but many have been taken during the past week. Ring-ousels liave been very scarce this autumn. The northern larks, fieldfares, and snow buntings have not yet been seen, as it is still early in the season for them.

'The various kinds of titmice, such as the tom-tit or ox-eye, blue-tit, cole-tit, and marsh-tit, are very plentiful about the suburbs of London. The nuthatch, little treecreeper, common wren, the golden-crested wren, and longtailed titmouse are also plentiful, and may be seen by any ordinary observer about the borders of woodsides and copses near London. These last-named birds frequent the same localities, and are especially fond of parts of the country where firs and yews abound; they do not seem to have increased or varied in numbers for the last thirty years, although very seldom trapped in nets, caught with birdlime, or killed by gunners, being useless except as specimens for the cabinet.

'The hooded or Royston crow has been noticed on the marshes below Gravesend. These birds are generally observed first at Flamborough Head, in Yorkshire, which is the great arrival station of many autumnal migratory birds proceeding south from Norway, Sweden, \&c. At Flamborough Head many of our autumnal visitors have been seen: scores of blackbirds, thrushes, crested wrens, and owls. These owls were probably bred in the rocks in the vicinity of Flamborough.

'Woodcocks are also beginning to arrive at Flamborough. These birds subsist during the summer months on the larvæ of the mosquitos and other inserts that breed in the extensive marshes of Norway and Sweden. The 
moonlight nights and easterly winds have been especially favourable for the arrival of birds from the north. At Flamborough the blue rock doves are also very plentiful. These birds are found nearly all the world over; they will not breed in captivity. At this time they feed on the stubbles, and do much good by eating up the charlock seed, which is their favourite food. These blue rocks must not be confounded with the blue rocks used for pigeon-shooting from the trap. Linnets and greenfinches also eat large quantities of charlock seed, feeding in flocks on the stubble lands.

'During the late foggy evenings numbers of the common mouse-eared bat have been seen about the streets in the north part of London. It is difficult to know on what these bats are feeding, as there is very little insect food now to be had.

"The common garden or geometric spider is now to be seen abundantly in our gardens. They are now fed up and are depositing their eggs: their nests are to be found under fences and posts; the eggrs are beautifully packed away by the mother spider in an elegant silky web or covering. After depositing the eggs the spiders become very weak, and are easily snapped up by the sparrows and tits. Again, these spiders'.eggs afford food during the winter months for various small birds.

"The threads of the gossamer or aeronautic spider may be now seen in bright calm weather. It is supposed that these spiders ascend into the air by means of long delicate silky threads, which they shoot upwards into the air; but on this subject further observations are desirable. The silk-like webs of the gossamer spider are most noticeable 
on dewy mornings, as the moisture then adheres to them and gives them an appearance of frosted silver.

'December.-During the past fortnight great changes have been going on among the wild birds of this country. Towards the middle and end of November, the bird-catchers ahways expect what they designate the "November" flight of linnets." This great flight began this year about November 15 . On the 24th and 25 th very large takes of linnets were made by the London and suburban catchers. The men get their nets laid before daybreak. As soon as it is light the birds appear" they come in flocks of fiom two to three hundred; the call birds "charge," and give the catchers notice that the birds are coming, before they can be seen by the men. As many as five dozen have been taken at one pull of the clap-net this year. Although so many linnets are captured ammally, there has been no general diminution noticed in their numbers. These birds are mostly bred on the wild gorse lands, especially in Scotland: they are very prolific, and have three to four nests each season, producing from fifteen to twenty young. When this linnet migration from the north takes place, the bird-catchers know that some wild weather is coming behind them. This has been justified by the recent cold and winterly rain. The linnets, when arriving at the south of England, disperse themselves over the stubbles, "clover lays," and "fed offs," eating large quantities of charlock and other wild seeds, which otherwise would be injurious to the farmer. 'The large takes of these birds have glutted the bird market. Before the flight cock lianets were worth from four to five shillings a dozer. now they are onls fetching eighteenpence to two shillings. 
A very rare bird has been taken among the linnets at Highgate, namely, a hybrid between a common greenfinch and brown linnet.

'Goldfinches are now becoming' very'scarce, on account of the cultiration of land exterminating the thistles. This rear, for the first time, the bird-catchers have gone expressly to Ireland, and have sent large takes of goldfinches thence into the London market. During the antumn goldfinches were abundant; the reason of this may be attributed to the provisions of the Bird Preservation Act. At this time of year the goldfinches lie up in quiet feeding places, and remain there as long as the food lasts; they will not be seen on flight again until April. The siskins, chaffinches, bramblefinches, and hawfinches that came in the last Michaelmas flight, and located themselves where food was abundant, are now gone, and the bird-catchers cannot find their whereabouts. In all probability they will not appear again on Hight until the middle or end of February. Fieldfares, redwings and missel-thrushes have arrived in large quantities, and are to be found about the environs of London so long as they can find food; they are very wary birds, but the moment frost and snow set in they are very easily approached. The redwing of all the thrushes is the most duck-hearted; he will soon succumb to the cold, even when the berry food is abundant; he cannot exist long without "ground food," that is, worms and insects. Bullfinches are still plentiful, there being abundance of food for them, such as old blackberries, privet berries, and dock seed; but they do not begin on the privet berries as a rule until after the frost has touched them. The aberdevines, or siskins, have entirely disappeared, the cause being that 
there is no alder seed this year ; these birds subsist almost entirely on alder seed during their stay here in the winter, and never breed in this country except the north of Scotland. The Scotch larks are unusually abundant in Enyland this season; they locate themselves on the clover and grass lands, where they are taken by thousands on dull nights with trammel nets. At this time of year they are sold dead indiscriminately, both cocks and hens, just as they are caught. By the end of January the catchers can find ready purchasers of the live cock birds. The price of cock larks then rises monthly up to the end of April. In January they fetch four shillings a dozen, in A pril there is a ready market at twelve shillings a dozen.

'Wood-pigeons are very numerous this wiuter, and large. numbers are now in the London market. Just now they are in the very finest condition, and are regular "lumps of meat." They are very good for table when stuffed with sage and onions and roasted like ducks. When the severe weather sets in, the damage that will be done to the farmers by wood pigeons will be alarming; they will destroy large quantities of swedes and turnips, spoiling more than they eat. These birds peck out the heart of the green part in the centre of the turnip; in doing this they make a deep hole, the water then gets in, and the turnips are destroyed by the first frost. This year there are no beech-nuts; the wood-pigeons, therefore, will more than ever make inroads among the turnips. Wood-pigeons also do much dainage to the vetches grown for early lambfeeding.'

An interesting article was also written in this year on the 'Evidence of Design in Birds' Eggs.' 
' It is my constant endeavour to discover in all created things evidence of the design of the Creator. I find written in my copy of Paley's "Evidences" a capital quotation formularising this idea:- "Can a clock go without a weight or spring to move it, or a keeper to set it?"

'I think I have now a new fact-at least new to meto prove design in the formation of birds' eggs. It was casually mentioned to me by Mr. Edon, curator of $\mathrm{my}$ Fisl Museum, South Kensington. He has remarked a rery striking difference in the shape and form of the egg's of birds, which build in nests or holes, as contrasted with the shape of the eggs of those birds which build on flat surfaces. The kingfisher will place her eggs at a considerable depth in the earth in rats' holes, sand-martin's holes, etc. Her eggs are nearly round. The owl builds in holes in trees, etc., and her eggs are perfectly round. The long-tailed tit builds in a very deep nest; her eggs are also round. The reason of this is that the eggs shall pack well in the nest, and all of them get a share of the warmth from the mother's body as well as ventilation.

' Birds that lay their eggs in holes, as noted above, have round eggs. There are, however, certain birds which incubate their eggs without any nest at all, upon the ledges of rocks. In this position it is very possible that danger would occur to the egg, by being accidentally moved by the parent bird, or may be by the wind. If the egg was round, it would very probably roll off the precipice, and, falling to the bottom, be smashed. In this case. of course, there would be no bird. Let us now see how the difficult problem of the preservation of this egg is managred 
by creative wisdom. The egg of the guillemot, to take a good example, is not round, but elongated at one end; the consequence is, that when it is touched the egg will not roll away like a billiard-ball, but it will simply turn round upon its own axis. This peculiar structure can be seen, and the action of the force upon the egg illustrated, by a very simple experiment. Take a common screw, and place it near the edge of the table; touch it gently, so as to set it in motion. You will observe that the screw, instead of running off the edge of the table, will simply turn round on its small end-its own axis. I cannot conceive anything more beautiful, than this arrangement of the eggs of birds, which build on ledges of rocks, and which are very liable to destruction. This fact will, I think, afford excellent eridence (if more witnesses were required) to show creative skill even in such simple things as birds' eggs.'

Further correspondence followed in 'Land and Water,' which confirmed the rule generally, with some apparent exceptions, as in the case of the dipper which lays pearshaped eggs like most wading birds, although its nest is deep-domed, like a gigantic long-tailed tit's nest. The eggs of the guillemot, the razorbill, and the puffin are pear-shaped, in proportion to the exposed position of their nests. The guillemot lays in the most exposed situation of the three, and has by far the most pear-shaped egg; the razorbill, which does not lay in quite such exposed situations, has a rounder egg; whilst the puffin, which always lays in holes, often in rabbit-holes, has the roundest egg of the three, in shape more like a hen's egg. The orster-catcher usually makes its nest in a slight hollow lined with stones, and lays four eggs, with the narrow 
ends inwards, thereby perfectly secured against the wind; they do not taper so much as the single egg of the guillemot, neither is it necessary, as the small stones and shells, together with the position of the eggs, being four, disposed with their small ends inwards, prevent any possibility of their rolling.

A lecture before the Sanitary Institute on the pollution of rivers as affecting pisciculture, followed by a soirée at his Museum, were among the incidents of 1878 ; but earnest devotion to pisciculture, the serious business of his life, and to natural history, its chief enjoyment, was united with a passion for every natural curiosity and oddity.

The various exhibitions at the Westminster Aquarimn attracted his constant attention, and successive articles were written, not only on the Fishery Exhibition there in 1877, for his contributions to which he received a gold medal, and at which he met Lord Beaconsfield, but also on the Laplanders, Benedetti the sword-swallower, the white whale, Pongo the gorilla, and other outlandish beings.

Strange folk visited him, on strange errands, and his occupations were a strange concatenation.

The Chinese ambassador called, and was taught how to cast fish.

The Chief Rabbi sought his advice, whether Jews might lawfully eat oysters, and Frank Buckland, in turn. consulted Dean Stanley on the interpretation of Moses' law as to things that creep, and pondered the question, Do oysters creep? The decision was against the oysters.

One morning he held a large meeting at his Mruseum, to receive $\mathrm{Mr}$. Mundella, and enlighten him on fishery questions. In the evening he went to Brighton, and 
prescribed for the sea lioness. Another morning he gave evidence before the Committee on Mr. Mundella's Bill. In the afternoon he welcomed the white whale on his arrival in London, and helped to put him into his tank at the Westminster Aquarium.

This variety of visitors culminated in a party given by him in Albany Street, in November 1878; men of science and art and social rank were there in plenty, with dealers in wild animals, bird-fanciers, and fishermen. The Chinese ambassador's peacock's feather nodded above them all. A special selection of many different kinds of oyster had been prepared, to illustrate their variety, and grace the entertainment; but, unluckily, the Chinese ambassador met them coming upstairs, and before anyone could find words or signs to describe their scientific rarity, devoured them all.

$\mathrm{His}$ home life at this time was thus graphically described in an article in the 'World,' on Mr. Frank Buckland as one of the 'Celebrities at Home.'

" "It's a jolly little brute, and won't hurt," exclaimed Mr. Buckland, as we were about to retreat from the threshold. The monkeys had seized the jaguar's tail, and lifting it up with its hind legs bodily to the altitude of their cage, were rapidly denuding it of fur. No animal with any feelings of self-respect would submit silently to such humiliation, and the jaguar was making the place hideous with his yells.

'Hearing the cries of her pet, Mrs. Buckland came to the rescue, and it was amusing to see this child of the forest, with gleaming eyes and frantic yelps, cast itself at her feet, and nestle meekly in the folds of her dress; she had nursed it through a very trying babyhood, when Mr. 
Bartlett had sent it from the Zoo, apparently dying and paralysed in the fore-legs, with a promise of $15 \mathrm{l}$. reward for a cure. That sum has long since been swallowed up, in damages for clothes destroyed and boots devoured, as the invalid's health and appetite returned.

'Hard by a laughing jackass was sportively chasing live mice up and down a glass jar, as an appetiser before eating them; and below, solemnly weighing the doctrine of chances, a battalion of cats waited patiently what might befall. At a front window, an intelligent parrot kept calling cabs from the moment we entered, and was equally ready to hail an omnibus if we preferred it. A peaceably disposed piebald rat was enjoying gymnastic exercises on a pole, until seized by his master and told to "Sing up, old boy." Held suddenly to our ear, melodious notes were heard issuing from the diaphragm, which Mr. Buckland considers as good as the carol of a lark, whether it arises from a parasite in the liver or not. All around, the walls were covered with the heads of curious hybrids, and horns of extinct animals, and, indeed, there was everything in this wonderful museum to fascinate the mind, from a shoe left as a keepsake by Brice the giant, to a lady's slipper floating about in a wine-glass of water. The latter was a beautiful little object like a fairy glass slipper, about an inch long, without heels and exquisitely fringed off. It belongs to the jelly-fish tribe, and was alive and well when we saw it.

"The "happy family" life, of which Mr. Buckland is the centre, is carried on in an ordinary London house, formerly the home of Charles Dickens' father-in-law, Mr. Hogarth, in Albany Street, Regent's Park. In their time, 
the room, into which we were ushered, was probably the drawing-room. At first, during the present tenancy, it used to be called "Master's room"; now it is termed the "monkey room," which Mr. Buckland remarks, " is Darwin going backwards." The dining-room is indeed the one room preserved, but with difficulty, for the sole use of man. It is held, so to speak, at the sword's point, against the incnrsions of animals from the neighbouring jungle. Sometimes the rule is relaxed in cases of sickness, or on the arrival of a welcome little stranger, like the jaguar. It is to this room that all good animals expect to go, in a stuffed fornt, when they die. It is regarded as a "Poets' Corner" for the great, while the bodies of the less distinguished are consigned to honourable burial in the back garden. Mr. Buckland was informed, lately, that there was not room to bury so much as a bird there now. Some excellent pictures adorn the walls of this room; one of Master F'rank, by Phillips, " aged 3 ; born at Christ Church, Oxford, December 17, 1826." He is characteristically portrayed lugging a guinea-pig in his pinafore. A bust of Mr. Buckland's father, the late Dean of Westminster, stands on a table, which he and his wife purchased in Italy on their wedding tour, and is composed of various marbles. A handsome dish representing a salmon stands on the same table, and was a gift froin His Royal Highness Prince ('hristian.

'Below all this we come upon the practical workings of the scientific mine. Next to the kitchen and accessible to the area is the casting-room, to which everything extraordinary, whetlier from the depths of the sea or the bowels of the earth, sooner or later gravitates. It is 
here that a prodigious amount of work is done, and goes forth, in the most finished state, to adorn the South Kensington and other great museums, for the advancement of science and education of the people. Round the walls are ranged bottles, casks and jars, containing specimens in every stage of what the naturalist might call preservation and the ignorant decay. Enjoying the rare art of imparting his knowledge to others, Mr. Buckland delights in showing his treasures. Regardless of fearful odours, he will plunge up to his elbows into a deep dark tank, and draw forth a slimy dripping reptile, and ask cheerfully, "if he is not a beauty." It requires a strong stomach and no small diplomacy to know how to act, for he is ready, on a word of encouragement, to make another fatal plunge and bring up the other seven.

'But another joy awaits you-if you can bear it-in a jar, when he carefully hauls out a ribbon fish, and tells you it is the next of kin to the great sea-serpent. At that moment, you heartily wish the great sea-serpent would bury its own relations, but Frank does not, and anyone, who would bring him the head of the family, would be his friend for life. On the whole, Mr. Buckland prefers live snakes about him, but he has not yet succeeded in getting his household to agree with him. A live snake is considerably worse than a pickled snake; seeing that the latter, they find, is not so likely to be found under their pillows.

'Perhaps the worst moments for the family are those when the Parcels Delivery van drives up to the door. On these occasions, there is a general closing of windows observable in the neighbourhood, and the only light-hearted 
creature within the zoulogical circle of Frank Buckland's home just then is the persevering parrot, who takes the credit of the van's arrival to himself. The Naturalist steals out to survey the state of things, and if likely to be very odorous, the man feels uneasy, while the husband, deep and treacherous, drops a propitiatory sovereign into his wife's hand, and recommends her to try a little shopping in some distant region. Once it was a gorilla in a cask, and, when his unfortunate wife returned to her home, she found Frank in high spirits and the gorilla in even higher.

'Mr. Buckland's chief domestic grievance is the duster, which he regards as a mischievous invention of women. Household operations have consequently to be conducted by stealth, and usually in his absence on official rounds as Government Inspector of Fisheries. Not long ago he returned home to find the giant's autograph washed off the dining-room ceiling, and was in despair, but discovering the row of postage stamps a foot or two above the door, marking the giant's height, he was, in a measure, consoled, and fell back for comfort on the shoe still safe in the Mnsenm.

'Mr. Buckland makes the scullery his chief atelier, and shares the kitchen, when she will let him, with the cook. 'This invasion of her premises she might not indeed take in good part, but it mollifies her to see her master in his shirtsleeves doing the very dirtiest work, and she has long since come to the conclusion that his place is far worse than hers : - she deals, after all, with what is fit for human food, but her master's whole time is devoted to skinning, dissecting, pickling and poring over the bones of "beastesses," the like of which no one conld look at, let alone dress; yet her master is so kindly and pleasant a gentleman, that she can- 
not refuse sometimes when he asks for her belp-not with that Solan-goose, however, which master said, contained all the elements of a balloon; it nearly gave her a fit when he made it cry out as if it was alive, and only by squeezing what he called the "voice-box" at the bottom of the windpipe.

'Let us stand by the kitchen-table for a few minutes, while the master bustles to and fro over his work. He is just now busily washing a splendid sturgeon, a "royal fish," which, properly dealt with, he declares, a cunning cook could serve up as fish, flesh, fowl, or good red-herring. Quaint and original must be many of the dishes which issue from Mr. Buckland's kitchen. The long-suffering cook, were she free to speak, might tell some strange tales of mistakes inevitable, of young crocodiles boiled down for stock, of food misapplied, and of diets given to the wrong animals. Mr. Buckland's housekeeping books cover a wide range.

'Not less peculiar than the fare provided by his kitchen, is the company to be met with at his parties. It is his especial delight to entertain celebrities on view in the Town. This penchant makes him the idol of all the clildren and stray waifs in the neighbourhood, who crowd round the door when a party is expected, or clamber up the railings to get a good view of the giant going in, or the dwarf coming away. The due etiquette to be observed at these feasts is at times perplexing. When Chinamen, Aztecs, Esquimaux, or Zulus are the guests, the chief difficulty is with the bill of fare; but the ceremonial becomes complicated if Mrs. Buckland has to choose which arm to take of the four owned by the Siamese Twins; nor are matters put right by Mr. Buckland leading the way with 
the Two-headed Nightingale; while much discussion was needed to decide whether Mr. Buckland should hand.in Julia Pastrana (the hairy woman), or that personage, by virtue of her beard, should take in the lady of the house. Now and again other contretemps occur at these feasts. Nothing could have been more appalling than what happened when Mr. Buckland was honoured at dinner by Tomati Hapiromani Wharinaki, and a number of New Zealand chiefs. The party had adjourned to the monkey-room to smoke the pipe of peace, when, for their amusement, the host turned some six and thirty slow-worms out of a box. Instantaneously the guests were transformed; the garb of civilisation slipped off, and they returned to the wild untutored savage. With one frantic glance at the slow-worms on the floor, they uttered wild yells and straightway fled. Downstairs the dining-room window was open, through this they bounded helter-skelter into the garden, like hounds breaking cover, and filling the air with a tapage d'enfer. Thence they spread over the neighbouring gardens, taking the low fences like deer. Two of them seeing another open window, and at it a peaceable old lady at work, headed for it, dashed in, and with their tattooed faces and awful cries nearly were her death. By this time the whole parish was up, a hue and cry organised, recruits joined from the railings, and the fugitives were run safely to ground. It appeared that they entertained a superstitious horror of the slow-worm; to them it was the "Ngarara"- the incarnation of the power of evil. 


\section{CHAPTER XV. \\ CONCLUSION : 1879-1880.}

'SALMON-EGG collecting;' Frank Buckland wrote in 1878,' 'is one of the most difficult, and I may say dangerous, tasks that fall to my lot. Those only who have gone through the difficulties of collecting these treasures can know the anxiety connected with the task; nevertheless, in the second week of January 1878, I went at it once more. The Government authorities of New Zealand having expressed by telegram to Sir Julius Vogel, AgentGeneral in London, their desire to have a further consignment of salmon ova sent them this spawuing season, I told Sir Julius I would do my best for them, though it was late, very late, this year to hope for much success.

'In the collection of salmon eggs, as in every other matter, the great rule is to take for granted that you will find nothing anywhere. I therefore go fully prepared for all eventualities. Here, then, is a list of my "spawning kit." First, the waterproof dress ; this very useful garment is in fact a diver's dress, and, when properly put on, admits not a drop of water. It has, however, one fault, it is apt to freeze when I am out of the water, and then one feels encased, as it were, in a suit of inflexible armour. Second,

1 Notes and Jottings from Animal Lifo, p. 66. 
the spawning tins : long experience has shown me that the best form of vessel in which to spawn fish is no paltry little tin, but a bath large enough to bathe a good-sized baby in. Third, a long shallow basket, to hold the salmon immediately they are caught, such as ladies use to carry their clothes when travelling; such a basket makes a capital salmon cage. It is easily sunk to the proper depth with stones, and the salmon live well and do not fret in it. The fish can remain alive in the water in this till they are wanted. Fourth, house flannel, cut into lengths of one yard; this is absolutely necessary to hold the struggling salmon. Those who are unaccustomed to spawn salmon, have an awkward habit of putting their fingers into the gills of the fish, and if the fish's gills are injured and bleed, he suffers much from it. I never to my knowledge killed a fish in my life while spawning it. Fifth, dry towels; these are most necessary, as the slime from the salmon makes one's hands very slippery, and it is a very bad thing to have slippery hands, for you may lose a valuable fish in a moment; besides which wiping the hands warms them, and, when working in the water at this time of year, the cold to the hands and arms is fearful, or, to use the expression of the cabmen, "all my fingers is thumbs." Sixth, bottles for experiments with milt and ova. Seventh, "Sphagnum" moss, to pack the eggs in the tins and cans. Eighth, wooden boxes, tied up in threes and fours, to pack eggs at the river side. Ninth, a large landing net. This is very useful for catching fugitive fish, which may happen to escape round the side of the net. 'T'enth, nets; one long heavy trammel, and two smaller trammels are best. Eleventh, ordinary baggage, and especially a bottle of scented hair-oil, 
with which to well anoint the chest and arms and tips of the ears, when working in the water; a most excellent and serviceable plan. I took this hint from the Esquimaux.

'Thus equipped, I started for Newcastle, writing all the way in the train, of course. Arrived at Newcastle, I took the train to Chollerford. The next morning a drive of eleven miles to Bellingham, and thence by train to Reedsmouth on the North Tyne. The main river of the North Tyne was too heavy for us, no net could possibly stand; so Harbottle, the head of the Tyne salmon watchers, had judiciously made his first shot in the river Reed, just above her junction with the North Tyne. He had marked down several pairs of spawners on this bed, and hoped to get the lot for me. We came up just in time to see our assistants with very long faces. It appears that they had, though the water was then running rapidly, got the net across, and some fish in her; just as they were bringing her round she caught on a rock, and immediately rolled "leads over corks." Just at that moment there came a heary spate from above; the men on the bank could not hold the net, and she straightened herself out beautifully, letting every fish in the net, of course, escape. We managed, however, to secure three half-spawned fish, from which we got a few eggs.

' We then packed up the wet nets and the kit on a cart, and marched off to a shallow in the North Tyne, about a mile above; where we thought we might have luck. During our walk thither, a regular winter's storm came on; the telegraph wires sang out their music as if laughing at us, and far away in the north was a jet-black angry-looking cloud, showing that a heavy storm was gathering upon the 
moors and great hills, that separate England from Scotland. We had no time to lose, as we knew the rain from this cloud would soon send North Tyne down in a heary spate. Turning off the highway, we passed down a hill to the river bank, and then the cart with the nets went across the river, while I waded over-not a very pleasant work in a rapid rising river, with great rolling slippery boulders under one's feet. However, we got to the island, and determined to fish the stream on the other side of it. There was great difficulty in getting the net across, the stream was so strong and rapid. At last Harbottle and six men got her over, and then beginning some fifty yards above, the trammel was run down stream to her. Great was the excitement, when we quickly perceived, from the bobbing of the corks, that the fish in the spawning-bed were masked in the trammel. She's a beautiful net is my trammel, though some find fault with her. She's like birdlime to a fish; let her once touch a fish's fin and she has the rest of him pretty quickly. Down came the trammel right into the net below in true orthodox style. "Look alive, lads, round with them both on to the bank!" Three fish! Instantly I was on to them as they kicked about in the water. First male, second female, third male. The males, fine big fish, with red coats on them as though they were going to a Horse Guards' parade, and beaks on the lower jaw enough to frighten one. The female, alas! had not an egg in her; had done spawning long ago. As I told Sir Julius Vogel, it was very late for eggs this year, and I was right.

'While I was examining these fish, the river spared us not; and I quickly observed that a bank of pebbles on 
which I had just been packing eggs was covered with water. We were all, therefore, only too anxious to be off;; as a long stay on a desolate island, for a winter's night, in the middle of the North Tyne, was not a pleasant prospect. Several of the party got into the cart; the more the safer, as the cart would be heavier in the water and less likely to tip over. As I was waterproofed up to my neck, I walked behind in the water, holding the cart-tail with one hand, and the precious egg-can with the other. The man whipped up the horse, and he managed to drag his heavy load across the river, the old cart (already over the axles in water) rolling about like a ship at sea, as the wheels tipped up over the boulders below. At last we got ashore all right. The cart then went back for the nets and the other men, some of whom waded, others rode across.

'As we sat on the bank we saw the North Tyne gradually rising. Lap, lap, came the little side waves to our feet. The island on which we had been standing became smaller and smaller, and at last down came North Tyne with a mighty rush; the stones which a few minutes before had caused the ripples and the "hovers," so dear to salmon fishers, quickly ducked their heads under water; and where there had been a loud-resounding rapid before, there was now a swift, black, deep stream, running like oil. This sudden spate was caused, of course, by our friend the black storm on the lills. In this part of Northumberland spates come on very quickly, owing to the mountains being so steep, and the moors drained so much more than they were in former years.

'With the spate in the river, came the storm upon us, 
a regular spiteful gentleman fresh from the caves of Eolus, iced rain, sleet, and snow. I was cold, very cold, but I would not let it be seen. I felt my wet suit of waterproof gradually freezing and becoming like a suit of armour, especially about the arms and throat; so we packed up and walked away as fast as we could, and got a sort of shelter under a railway arch, where I managed, with the help of a water bailiff, to get off the frozen dress; and then for a walk-I hate walking-into Bellingham. As we went along, a blacker cloud came over, and it began to snow, not in nice heavy flakes, but little sharp cutting spikes the size of peppercorns. The howling wind drove them along like a volley from an infantry reyiment.

'At last we arrived at Bellingham, and on our way home in the dog cart, a heavy winter snow-storm was on, and kept on all night. The next morning everything, from the distant hills down to the window sills, had put on a white nightcap. We could see, with a telescope, the river tumbling over Chollerford weir in the distance. We at once concluded, that it would not be of the least use to try for eggs, certainly not to-day, maybe many days, as all that snow had to melt, and come down off the hills into the river in the form of water. "Besides, Buckland," said my host, "you're a fortnight or three weeks too late to get the run of spawning salmon off the ridds." "Yes," I said; "I know that, but when Sir Julius and the New Zealanders say 'Go and try,' of course I must go and try."

'So I packed up, waited half a day at a country railway station, and got that night to Carlisle to try what my old friends the salmon in the river Caldew had to say.' 
The quest for eggs was continued in the Caldew: the season there proved also too late. 'But,' said Frank Buckland, 'the word can't is not in my dictionary;' so from the later rivers of Devonshire eggs were obtained, which were finally packed in the ice-house on board the 'Chimborazo' at the West India Docks.

'Everyone carrying a box or two of eggs, we arrived at the ice-house on board ship. Captain Smith opened it, and when I looked in I perceived that a portion of the bottom was covered with boxes of eggs and ice. These were Mr. Youl's boxes, that he had packed some three or four days previously. Searle and myself bundled through the manhole of the ice-house, Captain Smith handed us the boxes of eggs, and Searle and I shifted, with the iceaxes and ice-forks, the great slippery blocks of ice on to the top of our own boxes, filling up the interstices with broken bits. When we first got into the ice-house it was jolly cold, but we were so busy shifting the blocks of ice, that we soon had no time to be cold. We trust these English salmon eggs may be the parents of many salmon, which in future years may become established at the Antipodes, to the great increase of the wealth and prosperity of our good friends in New Zealand.'

It was not alone the sudden rush of water, the wintry 'spate' of the North Tyne, which added danger to his task. The long working in icy water, the clothes stiffened with frost and chilled with driving sleet, undermined even his strong constitution, and laid the seeds of disease which soon afterwards developed.

This was Frank Buckland's last journey to collect salmon eggs. In January 1879 he again went to the 
docks, and packed in the ice-house of the S.S. 'Durham' eggs he had received for Australia. A few days later he was attacked with inflammation of the lungs, followed by hæmorrhage, which confined him for ten days to his room. It was two months before he could return to his official duties. He continued, however, to work at his salmon report, and other articles.

This year's report contained a short history of the condition and prospects of all the salmon rivers under cultivation in England and Wales, and was the result of 'three and a half months' hard work.'

'As regards our salmon fisheries,' he wrote, 'it will be satisfactory to know that the physical condition and salmonbearing capabilities of each river have been now thoroughly examined and recorded. In fact we know all the physical circumstances advantageous to the salmon, and we can also put our finger upon the localities, where circumstances, whether natural or artificial, militate against the welfare of these valuable fish. The one great drawback to the full development of the fisheries of this country is undoubtedly dirty water, in other words, "pollutions." Clean and pure water is a matter of national importance, as regards the liealth and industries of the nation, as well as in reference to the development of the fisheries. It therefore behoves every individual of this great nation, whether in his public or private capacity, to apply his influence to the solution of what is really the great question of the day, viz., "the pollution of rivers." "

On April 23 he took the chair at the Society of Arts, at a lecture given by Mr. Willis Bund, but was obliged to leave the chair from a fresh attack of illness. 
In June, July, and August he nevertheless went to the West, North, and East of England, and completed the inquiry into deep-sea fisheries, and worked hard at this report, which was finished in November with its full account of British food fishes.

At Great Grimsby he met a committee, lately formed there, to enlist the aid of fishermen in observing and recording facts relating to sea fisheries. In order to teach fishermen how to observe and utilise their experience, a table of heads of inquiry was prepared, under his guidance, and distributed; and prizes were offered, to which many of his friends contributed, for those who should bring home the best and fullest information. Some of the last days of his life were spent, as he lay in bed, in reading and classifying the answers received, and sending off the prizes for the fishermen.

In 1877 and 1878 a formidable disease had appeared among the salmon destroying many thousands of fish. The subject was discussed in Frank Buckland's report presented in the spring of 1879, and in August he was directed, with Mr. Walpole and Mr. Archibald Young, to inquire into the causes and remedies of the disease. Public inquiries were held at fifteen places in England and Scotland where the disease was rife, and numerous diseased fish were examined and dissected, casts of the preparations placed in the Museum, and in August the report was presented. The nature of the disease, which existed also in Canada and other countries, was shown to be a fungoid growth attacking the fish while in fresh water; its true cause, though many were assigned, appeared as mysterious as that of other epidemics among men or animals. 
In June 1879, Herr von Bunsen, a son of Dean Buckland's old friend, Baron von Bunsen, visited England, to obtain co-operation in the Fishery Exhibition to be held at Berlin in 1880. To Frank Buckland's great regret, no aid appeared to be forthcoming from the British Government, but he determined that this country should not be unrepresented. He took Herr von Bunsen round his Museum, discussed with him the exhibits to be sent, and, notwithstanding infirm health, immediately began to prepare new casts for the purpose.

His interest in the current curiosities of the day continued unabated.

The friendly Zulus who visited London in July 1879 were interviewed and thus described:- 'There are six young men, all in the very prime of life, sound in wind and limb, and as active as cats. Digandau (chief), Possmon, Magubi, Nusan, Kikou, and Oskei. They vary somewhat in colour; all of them are black, but not the jet-black of the West Coast African nigger. The smallest of the six, a lad about sixteen, is lighter in colour. The hair is wool in little tufts. They resemble in figure statues of black marble, or bronze figures one sees in the Paris shops. The physiognomy of these Zulus is by no means disagreeable; I could find many much worse faces in the slums of London. Being a disciple of Lavater, I read in their faces goodnature and a kindly disposition, mixed with a peculiar expression not present in European faces. If improperly handled or offended, the features indicate instant revenge and merciless retaliation. These two characteristics came out well in their performances. Their dances were emblematical of fighting, and victory to the death over 
their enemies; whereas the representations of the marriage feast, and their dinner-time outside their kraal, showed that they were socially goodnatured, merry, happy people. When they came down amongst the audience, I was surprised to see the natural polite manner in which these Zulus bowed and acknowledged the flowers, which were presented to them by the ladies. One of the most marked cliaracteristics of the Zulus was their amazing quickness of hearing and sight. Though silent, they seemed to see and hear everything that was going on, and to be ready for any emergency in a moment. They were most at home when throwing the assegai. These really are fearful weapons; they are from four to five feet long, made of hard wood, and carry a blade or narrow spear of soft pliable iron about five inches long, cutting with both edges. When using the assegai they cause it to quiver in the hand in a peculiar manner before they throw it. This gives it an impetus; it flies through the air as quick and as silent as an arrow from a bow, and it strikes the object with a peculiar sullen thud. Two ordinary targets were placed one behind the other against a platform of boards. After a volley of two assegais thrown by each Zulu I found there were six golds, and the rest of the spears were very near golds. If the object aimed at had been an ordinary man, every assegai would have penetrated his chest. So deep had the weapons gone through the two targets, and into the wood behind, that the attendants had some difficulty in getting them out. I examined the wounds in the targets. If these wounds had been made in the human frame, being deep punctured wounds, they, if not at once fatal, would have been most difficult to treat. The dis- 
tances through which the assegais had pierced the targets averaged six and a half inches, independently of the point being deeply fixed into the boards at the back. The Zulus have been taken round the Zoological Gardens. They were dreadfully afiaid of the elephants; they knew quite well what elephants are, but had never seen a tame one, and regarded it as a natural enemy. The Cape hyæna was an old friend, and, when he laughed, the Zulus laughed with joy at meeting a countryman of their own. The ant-bear was turned out of his straw for them; him they greeted, but they were much puzzled with the South American anteater. In Africa, as we well know, there are no deer proper, but only antelopes; the Zulus were delighted with the elands, but amazed at the wapiti stag: they could hardly be persuaded that the wapiti's horns were not leafless boughs of trees. An amusing incident took place at the Gardens. A good-looking young lady at the refreshment department brought the chief some iced water. The chief, Dingandau, immediately wanted to buy her, and with seriousness asked how many cows her father would take for her!'

In November 1879, Frank Buckland held an inquiry among the fishermen at Cromer. On his way thence to Lowestoft he was caught in a violent snowstorm, which induced another attack of illness. This was the last inquiry he held.

'If a close observer,' writes his colleague, Mr. Spencer Walpole, ' 'were asked to mention the chief quality which Mr. Buckland developed as Inspector of Fisheries, he would probably reply a capacity for managing men. He had the

1 Macmillan's Magazine, February 1881. 
happiest way of conciliating opposition, and of carrying an even hostile audience with him. It frequently occurred that the fishermen at the many inquiries, which his colleague and he held, looked in the first instance with suspicion at the Inspectors. They never looked with suspicion on them when they went away. The ice of reserve was thawed by the warmth of Mr. Buckland's genial manner, and the men who for the first half hour shrank from imparting information, in the next three hours vied with one another in contributing it.

'Energy,' the same writer continues, 'was only one of Mr. Buckland's characteristics. His kindliness was another. Perhaps no man ever lived with a kinder heart. It may be doubted whether he ever willingly said a hard word, or did a hard action. He used to say of one gentleman, by whom he thought he had been aggrieved, that he had forgiven him seventy times seven already, so that he was not required to forgive him any more. He could not resist a cry of distress, particularly if it came from a woman. Women, he used to say, are such doe-like timid things, that he could not bear to see them unhappy. One night, walking from his office, he found a poor servant-girl crying in the street. She had been turned out of her place that morning, as unequal to her duties; she had no money and no friends nearer than Taunton, where her parents lived. Mr. Buckland took her to an eating-house, gave her a dinner, drove her to Paddington, paid for her ticket, and left her in charge of the guard of the train. His nature was so simple and generous that he did not even seem to realise that he had done an exceptionally kind action.' 
Many instances might be added of similar acts of kindness.

'Christmas week, for many years past,' Frank Buckland wrote in December 1879, ' has been to me a period of great importance; for this is the week in which the salmon are at the very height of spawning, throughout the rivers of England and Scotland. This also is the week in which I generally receive the consignments of great lake trout and eggs of Salmonidce from the Continent.

' This Christmas week, I regret to say, I shall not have the opportunity of spending my time up to my neck in water, collecting salmon eggs for Australia or New Zealand, from one or other of our northern rivers; or in one of the southern rivers, getting trout eggs for the Thames. I must say I very much enjoy collecting salmon and trout eggs ; it is very cold, and, at the same time, very hard work, but I very much prefer it to indoors and the fireside.

'If I can't get a job on the water, I must make one for myself on land; so I, with my friend Bartlett's permission, now give the result of a very pleasant conversation I have had with him, relative to Christmas time at the Zoological Gardens.

' It is a great satisfaction to us both to see how very popular natural history has become during the last few years. I am especially pleased to observe, that the similitudes or quasi-similitudes of birds, beasts and fishes are being introduced, whether for use or ornament, into domestic life. Moreover, if we look into the shop-windows, do we not observe how very dependent we are on the animal creation for food and raiment (witness the poultry shops and also the ladies' furs, sealskins, feathers, etc.)? But yot how 
fearfully ignorant most of us are of the habits of the beasts and birds which provide all these good things for us!

'Under these circumstances, let us direct our thoughts on what is going on, this mid-winter time, in the Zoological Gardens.

'No one goes to the Zoological Gardens at this time of year; nevertheless, severe winter weather (especially the snow and ice time) is of all others that which causes most anxiety.

'When we recollect what a number of animals in the Gardens are natives of tropical climates, such as Africa, South America, India, and of parts of the world situated under almost every kind of climate, it becomes obvious that the utmost care, study and constant watching, both day and night, are required to find proper house-room, warm sheltered quarters, and food for this hungry family, clothed in fur or feather, of nearly two thousand mouths, all told.

' In spite of all the difficulties of commissariat, board and lodging, the animals at the Zoological seem, and really are, very comfortable, and I trust happy. It is more tban probable that, as they are protected from heat and cold, from their natural enemies, and have their food regularly, they live longer in the Gardens than they would in their native homes, be it plain, mountain, forest, or jungle: for instance, the senior bird of the parrot-house is a Vasa parrot, presented July 25, 1830. This remarkable bird has never had a day's illness, has been merry, well fed, and is probably the oldest bird of the species in existence.

'Many of the animals at the Gardens are hardy 
enough to be allowed to roam more or less in the open. These, nevertheless, require great attention in time of frost; because the water which is given to them to drink becomes hard and frozen, so that the poor brutes, many of which know not ice, cannot understand that it is water at all; and that the meat given them for food, unless eaten immediately, becomes hard like wood, and consequently difficult, if not impossible, to swallow.

'Notwithstanding the many difficulties, not only can a good bill of health be shown, but the collection has of late been enriched by several rare and valuable additions.

'Of these, one of the most remarkable is a young penguin from Cape Horn, of the species known as the king penguin (Aptenodytes longirostris). This bird arrived in the remarkable state of a baby penguin-that is, with a plumage of down. This down is of a dark brown colour, and is upwards of two inches long. The bird had all the appearance of a penguin in a dress of bear-skin, the long flappers, or wings, being enveloped, as it were, in sleeves of the same fur. In less than ten days the bird began to moult its down, and at the present time the new plumage consists of a perfectly white breast and grey back, while the head and neck still retain the downy state. The bird is exceedingly fat, weighing upwards of $50 \mathrm{lb}$. He lives principally on sprats and herrings, of which he consumes large quantities daily.

'Another acquisition to the Gardens was made a few days since by the purchase of a magnificent pair of pronghorned antelopes (Antilocapra Americana), probably the first pair ever exhibited in Europe, at any rate the first pair ever brought to England. So little was the animal 
known or understood, that, until the year 1865, when Mr. Bartlett read a paper upon the affinities of this animal, before a meeting of the Zoological Society of London, in which he described and called attention to the remarkable fact that the prong-buck shed its horns annually, no naturalist in Europe or America had believed or suspected such was the case.

'During the last week arrived two fine young female Red River hogs (Potamochcerus pencillatus). This is a most important addition to the Society's collection, as the only living specimen in Europe of this beautiful species is a fine adult male in the Gardens. The history of this animal I will give in Mr. Bartlett's own words :--

" ' During the winter of 1875 I received from $\mathrm{Mr}$. Cross, of Liverpool, a small box about six inches square; upon opening the box a wee striped little pig, little bigger than a rat, put up his little snout and made a small squeak. With the winter advancing, and knowing from his form of ears that his native home was in West Africa, I took him out, and gave him a good feed of warm milk, boiled rice and sugar, wrapped him up in flannel, and sent him back to Liverpool, with a note to say I could not purchase him, as none of the keepers would be troubled with such a baby, and I felt sure the poor little fellow would die if placed in the collection. A day or two afterwards I was surprised to receive the same small box, and more so to find the unfortunate little pig inside, and a note from Cross to say the animal was of no use to him-he could not be bothered with it-and as I declined to purchase it for the Society, he begged ine to accept it, and do what I pleased with it. I felt hurt to find this poor little fellow thus an 
outcast and apparently friendless. I took him in my hands, and conveyed him at once into my kitchen. Calling the maid, I asked her if she would take charge of this little outcast, telling her, at the same time, if she treated him kindly, and kept him alive for one month, I would give her a sovereign. The girl, pleased at the offer, took poor Dick, for.that was at once his adopted name, and placed him in a basket with a warm blanket near the fire. All went well with Dick from this moment. Warm food and dainty morsels were Dick's frequent allowance. $\mathrm{He}$ was soon allowed to walk about the house, and, unlike most other swine, was the cleanest of animals. Few dogs or cats could equal him in cleanliness in the house, and thus Dick became a universal favourite, and after a while made his appearance regularly in the dining-room at dinnel-time, and had a plate to himself before the fire. $\mathrm{He}$ was the most good-tempered and well-behaved creature that can be imagined. His playfulness would sometimes frighten strangers, and, as he increased rapidly in size, he found it difficult to run under the chairs, and these he now and then turned over in his endeavour to rub his back or sides against them. In the early morning, before the Gardens were open to the public, Dick would follow me on my rounds like a pet dog, stopping accasionally to grub up with his snout a few earthworms, of which he was very fond, and while so engaged he would lose sight of me, but, the moment he did so, he would rush off like a mad fellow until he overtook me, and always seemed in fear of being left behind. He was very fond of being played with, and a birchbroom afforded him great sport. When held to him lie would 
charge at it with his tusks, small as they were at the time, and spin round in the most extraordinary way, dashing off to some distance, and then returning to the charge. He was never tired of this sham fighting, at which he never got out of temper, for, as soon as it was over, he would come into the house as pleased as any puppy after the fun. Dick, however, soon became too big for the chairs and tables, and as they were sometimes very much in his way he turned them over, not knowing, of course, that anything of value was damaged by his so doing; in fact, it began to appear that Dick had a notion that whatever was on the table was intended for him, and that the proper way to get it was to turn the table over. It was therefore decided, on July 25, 1877, that the time had arrived when Dick should leave the house, and he has since formed part of the collection in the menagerie."

"During one of the bitter cold days we have lately had, there arrived a very interesting addition to the Gardens; namely, a little bear, sent by Mr. Cross, of Liverpool, on "sale or return." Knowing my great liking for bears, Mr. Bartlett kindly brought this young gentleman down to pay me a visit. He was a funny little fellow, about the size of a large rough puppy, and a very knowing customer. When I took him out of his box and put him before the fire, he sat down on his haunches, turned his head round, and inspected the monkeys in their cage. The monkers did not know what to make of him. They did not show the same symptoms of alarm as when a snake is brought in, but they paid Mr. Bear very great respect, not even making a face at him. When let out of their cage, they took good care not to come on the ground, but invariably 
got on to the chairs, cage, or mantelpiece, always keeping one eye on the intruder. The bear was very inquisitive, and walked about the room on his short bandy legs, and pried into everything. What amused him most was to scratch up the matting forming the hearthrug and to hunt for something. This is his natural habit, to turn over stones, to catch beetles, worms, etc. His great delight was to get somebody's finger into his mouth; he would then immediately begin sucking most vehemently, making a peculiar noise all the time, as if much gratified. It was necessary, however, to keep one's finger in the middle of his mouth, as otherwise there was a chance of being nipped smartly by his canine teeth, which were quite large enough to hurt. He was very intolerant of cold, and would, if he could, get under the grate, and rake about among the ashes, sometimes even getting his fur singed.

'I tried to teach him tricks, and began by making him stand upright in the corner of the sofa. The little rascal, however, would not learn anything, and his edncation finished by his making a fierce rush at me, and my boxing his ears.

'To the servants a bear was a bear, and it was very amusing to hear the shindy they kicked up, when, in the course of his peregrinations about the house, Mr. Bear met them on the stairs, or went into the kitchen to warm himself. He had very peculiar eyes, very pig-like and cunning, and he was fond of coming up to a visitor, staring him steadfastly in the face, as much as to say, "Please give me something; I think you had hetter." He would eat almost anything, but his favourite diet was brend, 
milk and sugar. I am sorry to say I was obliged to send him back to the Gardens, or I should like to have made a companion of him, and I am certain, as he was tame, lie would have soon become obedient. I hope somebody will buy him for one of the pantomimes; he would, I think, be a great hit.

'A propos of bears, I do not think $\mathrm{I}$ have ever put on record the story about the bear who managed to get lonse at the Gardens. At daybreak, one fine summer's morning, the watchman reported to Mr. Bartlett that there was something alive underneath the chairs, which, as usual. had been piled up after the visitors had left. When Mr. Bartlett came to look at the chairs, it was quite apparent that there was somebody or something alive in the middle of the pyramid. Watching carefully among the legs of the chairs, at last two black eyes were seen; these were apparently bear's eyes, so they counted the bears in the bear-pit, and one of them was found to be missing. The difficulty now was to get the bear back into the pit. The chairs were removed, one by one, till the bear remained unconcealed. My gentleman then got up on his hind legs, and showed symptoms of becoming nasty.

'The bear was then surrounded by keepers in a lalfcircle. The best thing in the world to fight a wild animal with, is the stump end of a besom. The bear, knowing his way back home, went up the steps and ran along the parapet, orer the cages in which the lions at that time lived. When he got home to his bear-pit, he evidently did not like the jump down, so he reared himself up on his hind-legs, and swinging himself backwards and forwards began to swear in a bear-like manner. While the stupid old bear was 
making a fool of himself in this way, Mr. Bartlett took a run at him, and knocked him clean over into the bear-pit with the stump end of the broom. He laid there a long time with all the wind knocked out of him. At last he got up, shook himself, and sneaked off into his den, where he lay mumbling for several days, but ultimately came ont none the worse for his expedition among the chairs, or his tumble backwards into the bear-pit.

'Though bears are very good climbers, yet it is a mercy they cannot jump, or otherwise they would have long ago jumped out of the bear-pit from the top of their pole. Some years back a young man, on a sixpenny day, had an adventure with the bear. I suppose the heat of the weather (or other disturbing causes) made him drop his best holiday hat right into the bear-pit. The stupid fellow at once got down into the bear-pit, alighting on the top of a big bear who was coiled up sleeping in the sun. The bear got up, and taking the man by the shoulders, began waltzing round with him. Luckily the man kept his feet, and nothing worse happened, as the keeper drove off the bear, and let the man out at the side door. He forgot, however, to take his hat with him, and left it in the cage ; the bears, of course, tore it up. The cool impertinence of this man was greatly to be wondered at, as next day he actually sent in a bill to the Society for a new hat.

'Ladies must take notice that Mr. Bartlett is not responsible for bonnets or feathers stolen by the monkeys. He was once summoned by an old woman for a bonnet. The old woman produced a shabby old bonnet in court which she valued at an exorbitant price. Mr. Bartlett, on the other side, produced the notice-board from the monkey- 
house warning visitors against the peculating propensities of the monkeys. The old woman lost her case.

'There is a very curious bear at the Zoological Gardens now. He sits up when he sees anybody coming and begs for what he can get. If he is shown anything and does not get it, he pretends to commit suicide, turning round and biting himself all over most furiously. This is an amusing beast. He cannot bear being laughed at.

'A curious occurrence has lately taken place at the Gardens. One night one of the lions was observed to be in a state of great tribulation, rolling about, and trying to get something out of his mouth with his paws. Upon examining the animal to see what was the matter, Mr. Bartlett found that a great bone had become a fixture in the poor brute's mouth. The difficulty was to remove it, as the lion was in a fearful temper. This was done by getting the lion into a "shifting den," where his face would not be very far from the bars. It was then ascertained that the object in the lion's mouth was the spongy round bone, as big as a cricket-ball, which forms the hip-joint of a horse. The lion had had part of a haunch of lorse for dinner, and in amusing himself with the bone, first got his upper large canine tooth into the soft part of the bone, and biting on it, the corresponding canine tooth in the lower jaw came through so far into the bone that it nearly net with the point of the upper tooth, and the jaw became fixed. The animal was thus prevented from taking food or water. Mr. Bartlett, with a great deal of tact and manœurring, managed to get this bone ont of the lion's mouth, and fortunately, as it was found that the long projecting portion of the bone was pressing hard 
upon the lion's tongue. This is the third clever operation in dentistry that Mr. Bartlett has performed-first, removing a big tooth froin the hippopotamus; second, operating on the base of the tusk of the big elephant; third, taking a horse's leg-bone out of the lion's mouth.'

Frank Buckland's last. Fishery Report was presented on March 31, 1880. 'I have determined to make this report, he wrote, 'as far as possible an outline and guide to those who wish to open up and improve salmon fisheries, in whatever part of the world they may be situated, and more particularly in our owa country. To Ichthyology (both general and special), and to the art of angling, many works, from the days of Izaak Walton 200 years ago downwards, have been devoted, but no special treatise upon the general management of a salmon fishery, in other words on salmon farming, so far as I know, exists.' This report contains a most interesting description of the anatomy of the salmon, of its food and habits of life, its breeding, capture, and diseases, and will well repay perusal.

Although failing health restrained him from bodily exertion, and warned him too plainly that his course was nearly run, his intellectual activity did not flag; it seemed rather stimulated to increased exertion, while life remained.

$\mathrm{He}$ devoted much time to the arrangement of specimens for his Museum, which he now determined to leave to the nation to perpetuate, to the utmost of his power, that knowledge and love of pisciculture, which he had laboured to spread through all classes of people.

Many of his last days were spent in arranging and naming the various kinds of oysters, and other specimens for the Museum. 
On April 20, 1880, the International Fishery Exhibition at Berlin was opened. Baron von Bunsen, vicepresident of the German Fishery Society, acted as British delegate. 'This,' Frank Buckland wrote, 'is what he says on behalf of England: "True to the ancient English tradition of preferring individual enterprise to state action, Her Britannic Majesty's Government declined to apply for any appropriation of the public funds, towards participating in a Fishery Exhibition of all nations. Alone, among the various countries represented at our show, England offers, in consequence, an Exhibition brought together at hap-hazard, incomplete, and out of all proportion to the greatness and splendour of British and Irish fisheries, to the capital invested in the rorking of them, to the perfection whicl the angler's sport attained there centuries ago, and proudly sustains to the present day. Who would guess, while wending his way between the tables of the one room, to which we have reduced our claim, that the country, which sent those specimens, was the first to restrain the senseless destruction of fish in its rivers and estuaries; the first to open up passages for the Salmonidae so long impeded by weirs and other obstacles; the first to start the policy of prohibiting the pollution of ponds, lakes and rivers, by the influx of noxious matters from mines and factories? Who would guess, that this small collection represents a race of men, who are at once the largest consumers of fish in the world, the most accomplished of anglers, and, perhaps, the keenest inventors in every branch of industry connected with fishing? As it is, we feel certain that Mr. Frank Buckland's collection, so well known to every visitor of the Liensington 
Museum, and disclosing as it does the vast extent of his acquirements, will command the attention of all true pisciculturists. Let us hope that its author may still find his way to Berlin to illustrate and discourse upon it with all the vigour of his eloquence and enthusiasm."

'As I read these words,' Frank Buckland added, 'I was overwhelmed with shame, to think that this great country, with our salmon fisheries, sea fisheries, especially trawl and herring, oysters, crab and lobster, and pilchard, all of enormous value and importance, to say nothing of the vast amount of capital invested in angling, should be ignored in the presence of the representatives of fish culture, not only in Germany, but almost every civilised state in the world. When I found that the United States Government had voted the sum of $4,000 l$. towards the exhibition of the products of that country, I was determined that England should, somehow or other, be represented. So I set to work with my secretary, Mr. Edon of the Fish Museum, and a working carpenter; Sir Cunliffe Owen lent me packingcases, and, by working very hard, we managed to send off from my Museum fifteen large cases full of casts, maps, diagrams, models of salmon-ladders, tables of statistics, photographs, \&c.'

His zeal received a severe check. 'The following is the delightful news I received from Baron von Bunsen, who most kindly superintended my exhibit: "No care was omitted; when opening your boxes I was personally present. Never did I see a greater havoc than that which this short and easy journey had produced. The damage is practically irreparable.",

The injury to his casts was a grievous disappointment, 
but borne with great equanimity. 'I cannot help thinking that this awful knocking about must be done by the vanmen and railway porters. That it is possible to send goods without being fractured, is evident from the fact that the most delicate glass thing's come perfectly safe from Vienna and other parts of the Continent. Why should not other cases of goods be treated as carefully as these, or say boxes of eggs? It is not the heads of the carrying firms who are to blame, but the rude uncultivated men, on whom, I believe, the blame is to be laid.'

A gold medal and a special diploma were awarded him for his exhibits at Berlin, but were not received in his lifetime.

Dropsy set in, for which, in June, he underwent an operation, many times afterwards repeated. 'Refused chloroform,' he quaintly notes, 'as I wished to be present at the operation.'

A visit to Margate for some weeks revived his strength, and gave hope that the vigour of his constitution might even yet conquer disease.

Rest from bodily work did not relax the activity of his mind. He pictured the history of the past, and examined the fishing and shrimping of the present day, as the fishermen clustered round him on the beach; and he wrote this description of his enforced holiday.

'In vain do I try to take a holiday. Here I have been at Margate but a few hours, with order's to do nothing, yet ny "buttons," John, has put out blank paper and new pens, and perforce I must write what I have been able to pick up from the balcony of my hotel.

'I can't yet make out who the natives are, ethnologically. 
speaking. During our fishery inquiries the type of the fishermen generally gave the probable origin. Thus, on the south coast of Scotland the natives are Norwegians; on the west Celts. I think the Margate folks are Saxons -they can't be Danes. The Danes only came over here to plunder, and are not likely to have fraternised with the natives of the land, in the days of king Sigeburth, A.D. 64.8 .

'The bathing seems to be excellent, to judge from the crowd one sees in the water. From a distance, a school of boys in the water looks very like a herd of seals at play. Why don't they teach both men and women to swim? A swimming-master to attend the bathers, at twopence a lesson, would do well here. The bathers could be coached from a boat.

'Shrimps-the whole place seems to be shrimps, one penny a pint. They are not the brown shrimps, but the white prawn-like shrimps, Pandanus, first discovered, I believe, at Yarmouth some forty years ago. There are also many mussels, especially on the iron pillars of the jetty, where they grow in great bunches. The fishermen are wise enough, when picking them, to put back the small ones to grow. These mussels are much used for hop and corn manure.

'In the far distance one can see the great foreigngoing ships going up or down Channel, to or from the port of London. Just now, in fine weather, these ships, with all the sails set, look like gigantic birds; especially beautiful when the setting sun lights up their sails. The sunsets at Margate are, I am told, well known in the artistic world. Turner-who, as Ruskin says, is the only man who could ever paint sunsets-used to come 
to Margate to study the lovely skies and clouds as King Sol dips his head below the horizon. A great deal of the beauty of these Margate sunsets may be attributable to the setting sun illuminating with its gorgeous colouring the great banks of London smoke far away to the westward.

'In the winter the ships sometimes come to grief, and several fine sea-going boats, now painting up in the harbour, go out to save life and property, or carry out an anchor and chain to sell to ships. In December 1877, no less than twenty-five ships were ashore within sight of Margate jetty. There are no finer seamen than the Margate luggermen, and an accident to them seldom happens.

"Margate, I believe, was the place where "hoys" were first used. As far as I can understand, a "hoy" was a cross between a barge and a lugger. In former times they were considered wonders of speed and comfort. In a book published in 1820, "A Picture of Margate," the number of packets, hoys, etc., which belonged to Margate Harbour is said to be about seventy. The crowd which collected upon the pier to see the packets arrive was called "hoy fair." The excellences of the "hoy" have been celebrated in verse thus :-

Go, beauteous hoy, in safety every inch.

' In former times Margate was much used as a port of embarkation for the Continent. William III., we are told, often came to Margate in his way to and from Holland, and George I. twice landed here. Queen Caroline, wife to George II., came first on shore at Margate, and the great 
Duke of Marlborough chose this for his place of embarking and landing whenever he went to or returned from his campaigns. The Duke of York embarked and returned here in his expedition to Flanders in 1793. Admiral Duncan also landed here after his glorious victory over the Dutch fleet in 1798.

- The air of Margate is wonderfully pure. It is manufactured in the far, far North, right among the ice floes of the far-distant Polar regions, the home of the whale, the seal, and the walrus. A vessel taking her departure from Margate, and steering her course N. half E., would hit no land until she arrived on the coast of Greenland, in latitude $75^{\circ}$ North, after a run of 1,380 miles.

' From the window I can see Reculvers in the extreme distance.

'Reculvers was the Regulbium of those splendid soldiers the Romans. Here as everywhere else the Romans have left lots of money about. I cannot account for this, except that they had no pockets in their armour. In the time of the Romans, vessels did not go round the North Foreland, but through an arm of the sea, which in fact formed the Isle of Thanet. At the northern end was a fortress and a look-out, Reculvers, i.e. Regulbium; at the other end was Richborough. The little river, Wantsume, about marks the line where this ancient sea communication passed.

'When the Romans came to England, Julius Casar probably looked upon a different outline of cliff than the Lord Mayor of London will see when he arrives in state tomorrow, and tbis alteration in the cliff line has been made in a curious manner. First there comes a sun-crack along the 
edge of the cliff; the rain-water gets into the crack, then comes the frost: the rain-water in freezing expands, and by degrees wedges off a great slice of chalk cliff; down this tumbles into the water, and then Neptune sets his great waves at work to tidy up the mess. These waves soon knock all to bits the tottering walls of chalk, which look like great slices of wedding-cake. T'hen the waves set to work and polish up the harder bits of chalk into rounded masses from the size of a pea to that of a billiard-ball. The flints are collected, and dwelling-houses made therewith. Flints are the best and most lasting of building stones; just go and try to hammer a bit out of the Roman wall at Reculvers, and you will find the Romans knew how to build walls better than the London contractors of our own epoch. In the Roman wall the mortar is harder than the flints. By the way, at a certain watering-place in Wales, most extraordinary pebbles are frequently found by visitors, whu take them to the local lapidaries to be cut into brooches, \&c. These wonderful stones are home-made jewels, manufactured $b_{v}$ the innocent waves of the ocean in this wise. At the end of the season all the old sodawater and lemonade bottles are collected, and thick bits of glass at the end of the bottles knocked off. These lumps of glass are thrown into the sea; the sea rumbles and tumbles them among the shingle all the winter, and, by the time the next visitors' season comes round, they are converted into all sorts of precious stones bearing hard names, and are accounted great curiosities.

'In this part of Kent we find many names of places ending in gate: thus, Kingsgate, Raunsgate, Margate. Margate, the gate of the mere, or small stream, running 
into the sea; Kingsgate, near the North Foreland Lighthouse, is the gate (i.e. road cut through the chalk cliff), where Charles II. landed in 1683; Ramsgate is said to derive its name from Ruim, the ancient name for the Isle of Thanet, and gate, or else from "Roman" "gate."

'Being fond of sea fish, I went out on to the end of the jetty, with a friend, to try our luck. John, the buttons, followed us with the fishing kit. I find that the more tackle I take the fewer fish I catch. I carry my tackle in a patent box of my own construction. My box acts as a box, a seat, and a life-buoy. It is simply a box made bottom, sides, and ends, with thick, rough, heavy cork, having a wooden lid, also corked like the rest of the box; this shuts close. In case of an accident I can empty out the fishing kit in a moment, and have a capital life-buoy ready at once.

"Though we tried every bait, ard all sorts of tackle, neither of us got even a bite or a nibble, not even an eel. The result of our two afternoons was one mite of a green shore crab, and we agreed with the angling poet of old who wrote-

Much for my sport I camot say, Though, mind, I like the fun.

Here have I sat the live-long day

Without extracting one.

However, though we got no fish, we found out the corner where the fishermen gutted their fish, and I got some capital preparations.

"The fishermen leave the teetl in the mouth of the skates and dogfish. These teeth are very beautiful, like the finest tesselated pavement. I understand that at 
another watering-place, which shall be nameless, they cut out the rows of these pavement-like teeth, and sell tlem to visitor's as the male and female "shuttle shell."

"Though the Roman galleys and merchant vessels, inward bound for the port of London, saved about twenty miles of their journey by coming through the arm of the sea, which made the Isle of 'Thanet insular; this "Suez Canal" of those days has not been narigable for many a long year. The only road, therefore, up the Thames for slips inward bound from the south is round the North Foreland. For many hundred years, therefore, this " Promentorium Cantium" has been the headland chosen as the site of a pharos or lighthouse. Until comparatively modern times, a simple fire was kept burning all night; now the North Foreland Lighthouse throws its rays twenty miles out to sea. One of its chief uses is to point out the position of the terrible Goodwin Sands.

"There is much mystery about the Goodwin Sands. They derive their name from the Earl of Godwyne, who was, in 1020, created Earl of Kent by King Canute. In his days the Goodwins were an island, called Lomea. These sands are ten miles long by two wide. They are composed of a porous, tenacious material of a red tint, and are quite hard when dry. Sometimes cricket matches are played upon them, excursions being made from Ramsgate. When the tide comes up they become immediately a quicksand, and wrecks very soon get buried in them. It is a question, first, whether the Goodwins were submerged in a great rising of the sea which is on record, A.D. 1097 ; second, whether the land has not gradually sunk down; third, whether the Goodwins do not form a 
portion of the land, which originally connected the white cliff's of Kent with those of France. The banks called the Varne and the Ridge, between Folkestone and Boulogne, probably also are remains of the junction, which must have existed before any written records, as the Saxon chronicler's say nothing whatever about it. My father, the Dean, used to say that, between Folkestone and Boulogne, the water was nowhere so deep as to cover the top of the tower of Magdalen College, Oxford.

The Reculvers was one of the first of the fortresses which the Romans built, when they conquered the Cantii, the original British inhabitants of Cantium, i.e. Kent.

' On Saturday morning, August 26, in the 54th year before Christ, about 10 o'clock A.M. according to an able paper on "Cæsar's landing in Britain," published in the "Archæological Journal," in 1876, the British commander-in-chief, Cassivellaunus, and his army of ancient Britons, paraded in battle-array on the high cliffs near Dover, first saw the Roman fleet approaching. Julius Cresar's admiral had anchored his fleet the night before off Wessant on the French coast. The signal for sailing was given about 12 at night, and he anchored off Dover about 10 next morning, remaining at anchor till about 3 in the afternoon.

'According to Julius Cæsar, he beat our ancestors, the brave Britons, at once; but it strikes me that General Julius Cæsar rather cooked his official report of this affair to the War Office at Rome, as no special war correspondents were allowed; for, according to a Kentish historian, the Roman general got much the worst of the first fight

D D 
with the Britons. At all events, le bolted back to Rome in a very unvictorious-like manner.

'I mentioned that the Roman soldiers used always to be dropping their money about. They seem also not to have been particularly careful of their jewellery. In a volume of "Archæologia Cantiana" several beautiful engravings of gold armillæ are given. These appear to have been massive gold bracelets or armlets, twisted in a peculiar manner. One of an uncommon pattern was dug up in November 1872, upon Chatham Lines, by some soldiers throwing up a battery. This armilla weighed $22 \mathrm{oz} .4 \mathrm{dwt}$., and the guld would have been worth $93 \mathrm{l}$. Wearing these torques was a custom of the Gauls, the Frenchmen of the period. One of these gold armlets was found in France, the intrinsic value of which was about $200 \mathrm{l}$.

'The transport ships, employed by Julius Cæsar' and his generals to bring the troops across the Channel, would not bear a favourable comparison to such ships in the British navy as the "Serapis" Indian troopship, the "Shah," or the "Minotaur" ironclad; but yet they did their work well. These Roman war-ships used sails made of leather, and, instead of steam power were propelled by oars, arranged in a very ingenious manner. Those of the lowest bench were short, while those of the highest benches increased in length in proportion to their height above the water. There were sometimes as many as eight or ten banks of oars, one above the other. The ships were also named, and here are some of the names: the "Centaur," the "Scylla," the "Pristis" (named from the sawfish with the flat rostrum edged with teeth), the "Insigne," answering to our "Redoubtable." 
'The ancient Britons, who lived in those days in Kent, were a noble set of fellows; they all dyed themselves a bluish colour, with a plant called woad (Isatis tinctoria), which is also called pastel. Query, does woad now exist in Kent? They were tall men; wore skins of animals, probably deer, wolves, foxes, martens, wild cats, otters, etc. They wore their hair very long, and allowed their beards to grow, so that they must have been formidable in appearance. They had cavalry, but their horses were small. Their regiments of chariots were very well organised. Each chariot was driven by an experienced man. When in action the warrior threw spears among the enemy, and then jumping down, fought hand to hand, retiring to the chariot which waited for its master. Sometimes they fastened sharp-cutting curved knives, or scythes to the axles of the chariots, and, driving into the thick of the enemy, cut them down. They lived principally in thick woods, and when the enemy pressed them retired into bogs. The food most choice among them was "chenerotes," "a kind of fowl less than a wild goose." Quer'y, was this a wild duck? Owing to the undrained state of the county there must have been plenty of wild ducks about. I expect they knew how to make decoys, somewhat similar to those in Norfolk and Lincolnshire. Strange to say, they would not eat the hen, the goose, and the hare. I cannot form any notion whence they derived this idea. Altogether they were probably very like the New Zealanders of modern times as first found in their native island, and conquered by us English.

"The first thing that most clever of generals, Julius Cresar, did upon his (second) landing was to establish a 
fortress at Richborough, then an island, get his ships through the arm of the sea, and establish another fortress at Regulbium, now Reculvers.

'As I gaze at Reculvers from Margate Jetty Head, I can almost recall into existence the Roman sentries pacing up and down on the tops of their fortified watch-towers, or the "Castle guard" of the regiment, the First Cohort of the Vetasii, the regiment on garrison duty while their trumpets sounded "Guard turn out," or a "general salute" maybe even to Julius Cæsar himself, or to Vespasian, his second in command.

'The arms and uniform of this Vetasian regiment must have been handsome as well as serviceable.

"Here is a list of a Roman soldier's "kit" :-A shield with an iron boss, 4 feet long by 2 feet and a-half broad, made of wood and covered with a bull's-hide-an excellent defence against a sword-cut. A helmet of brass or iron, with a plume, not unlike the helmet as worn by the French dragoons at the present time. A cuirass of leather covered with iron scales or rings, greaves for the legs, and a heavy shoe, studded on the sole with rough nails, a sword, and two javelins.

'But where are the Romans now, and where is their fortress? Gone; disappeared deep down into the bed of the ocean. The sea has eaten away the land, and the place where the Romans built their fortress, probably some half mile from the present towers of the Twin Sisters, has disappeared under the waves of the great North Sea. A portion of the walls still remains inland.

'The fact is expressed in the following beautiful lines :- - 
Omnia tempus edax depascitur, omnia carpit,

Onnnia sede movet, nil sinit esse diu.

Flumina deficiunt, profugum mare littora siccat,

Subsidunt montes et juga celsa ruunt.

Omnia mors poscit; Lex est, non pœna, perire:

Hic aliquo mundus tempore nullus erit.

'The Romans, fortunately, have left some traces at Reculvers. I obtained several Roman coins, and saw one representing the babies Romulus and Remus sucking a wolf. Mr. Bartlett thinks the story very possible, as the fiercest of animals when in milk seem to lose their savage nature; so that the story of Romulus and Remus being suckled by a wolf may be true after all.

"Out at sea, between Reculvers and Whitstable, is a bank called the "Pudding Pan Sand," from the considerable quantities of Roman Samian pottery every year dredged up from it.

' Reculvers was also the place chosen in subsequent jear's by the best known of Saxon kings. When Saint Augustine came to Canterbury, about 1060 year's ago, King Ethelbert gave up his palace at that place to hin, and went to live at Reculvers. St. Augustine was buried in Canterbury Cathedral, and Bede records his tomb to have borne a Latin inscription, of which the following is a translation :-

" "Fere resteth S. Augustine, the first Archbishop of Canterbury, who being formerly sent hither by the Blessed Gregory, Bishop of Rome, and supported of God by the working of miracles; both converted Ethelbert with this kingdom from the worship of idols to the faith of Christ; and also, having fulfilled the days of his office, dy'd on the ith of the Kalends of June, in the same King's reign." 
'Ethelbert is said to have been buried at Reculvers, but his grave must long ago have been washed away by the sea.

'The ruined church at Reculvers was built probably out of the stones that formed the Roman fortress and Ethelbert's palace, and there are many of these big stones now existing, for they were sold to help build the present pier at Margate.

'The following description, in the writing of the parish clerk of Reculvers, was found among the parish papers. I give it in its own language and spelling:"1805. Reculver Church and villiage stood in safety. 1806. The sea begun to make a little incroach on the willage. 1807. The farmers begun take up the seaside stonework and sold it to the Margate Pier Compney for a foundation for the new pier, and the timber by action, as it was good oak, fit for their hoame use, and then the willage became a total rack to the mercy of the sea."

'How angry Julius Cæsar would be if he only read this paper, and learned to what use the stones of his fortiess at Reculvers had been put by the good people of Margate!

'The true Englishman has one peculiarity, he is always willing to take an opportunity of examining the noble animal which he has chosen to represent his qualities, viz., the Lion. For many years lions were kept-as almost part of the Regalia-in the Tower of London, thence they went to Exeter 'Change, then to the Surrey Gardens, till, lastly, in our own time, the Lion House at the Zoological Gardens, Regent's Park, has thrown all previous lion shows quite into the shade. 
'It was reported to me that there was a sick lioness in Margate, and that she was in the collection of animals in the Hall-by-the-Sea. We were soon off to see the poor patient. She was the mother of five beautiful cubsperfect pictures-but had got an ailment of the lungs.

'It is a very curious fact that lions born and bred in captivity are always, when they grow up, much fiercer and more intractable than animals which are caught wild. What may be the reason of this is not yet determined. Lions, though natives of a hot country, can stand an amazing amount of cold. When Sanger's Circus was on its travels in Central Germany, a fearful frost came on that froze even the axles of the waggon-wheels-every man and beast suffered much, except the lions.

'I was very much pleased with Walter, the keeper', who takes the greatest pains with his beasts. The big lion and Walter were great friends, the lion rubbing his ears against the bars as he paraded up and down while Walter was showing us his points, and talking to him. What a change for the better from the olden tinnes when it was the custom to "stir him up with a long pole," or as was the case with Nero, the celebrated "fighting lion," so well known to our grandfathers, killing or maiming butchers' bulldogs, matched for beer against the captive king of the forest!

'Here is a lion story.-One dark thundery night, a certain caravan had pitched near a common in the West of England. It was the watcliman's duty to go round every hour to see that all was well. When he came to the lion's van, it was empty - the lion gone-two in the morning, a fearful night, a strange place, que fuire, as the Frenchman 
has it. The fact was reported to the master, who ordered up all the keepers, and sent them off with injunctions not to make the least noise, and to come back every ten minutes to report. After a while one of the men returned to say there was something alive in a furze-bush on the common, and that it was probably the lion. If it was the lion, he had struck down something and was eating it, as he could hear the bones crunch. He could not tell what the lion had got, but it was white, very white, and was struggling fearfully.

'The lion's van was at once drawn up near the furze bush, and a dark lantern thrown on the victim that the lion was munching: it was at last made out that it was a great big white goose that Mr. Lion had picked up for his early breakfast, and which he was loth to leave. So ther managed to get the lion, goose, and all into his van, and to this day the people of the neighbourhood know nothing of a lion having been roaming their common all night, and not even the local policeman could find the man that stole the goose.

'In the den opposite the lions' was a pair of tigers. As they pace up and down and cross each other's paths without touching, just the tips of their tails moving, their whiskers turned back, and singing a quiet purr-song, they could not but excite the admiration of all lovers of tigers. My late friend, Thomas L. Coulson, took immense pains, as manager of the Bristol Zoological Gardens, with his tigers. The tiger-cubs used in those days to be born in the Zoological Gardens with cleft palates-never so at Bristol. All depends on the feeding, a simple detail now pretty well known to all the proprietors of large carnirora. One 
necessary portion of a tiger's diet is that he shall have the hair of the animal (such as the sheep or goat) left on.

'Walter has got his tigers so tame with kindness that he goes into the den with them, and the striped beauties seem to like his attention. l'iger's, however, are but big cats, and their tempers uncertain.

'Much has been said lately about the destruction of life in India by tigers. It is perfectly true that many natives, especially peasants, postmen, and women, are annually eaten by tigers. The natives pay great superstitious reverence to Burra Bagh, as the tiger is called, and will not show his whereabouts. As a rule, I am told these "man-eating" tigers are old decrepit beasts, which have found out that a human being is a very defenceless animal, and easily pulled down, so they watch the roads for the postman, and the wells for the women.

'It is possible that the natives have a good reason for not liking all their tigers-in spite of the man-eatersbeing killed. The tigers live in the thick jungle, where, of course, human beings do not, or rather cannot live, and their natural food is wild deer of all kinds, and especially wild pigs. If the tigers are exterminated, the deer and the pigs root up and destroy their crops, and the produce of their farms and gardens.

'At the extreme end of the lion house was the monkey house. Among the monkeys I observed a very promising young capuchin, the species employed by the organ men; and so called because of the hair on the back of the head being like the black hood of a capuchin monk; they are far away the cleverest of monkeys, and with kindness and attention soon pick up their education. I purchased this 
capuchin; he had never been handled before, and was very timid, clasping his hands across his chest in a devotional attitude and making a piteous face. He also had a habit of shaking his head when spoken to; this I have turned to account; so "Margate Jack" and I on arriving home held the following conversation:-- " Jack, do you like Margate?" (Shake of the head.) "No." "Did you say good-bye to the other monkeys?" "No." "Do you like Walter?" "No." "Do you love the monkey boy?" "No." "Did he feed you well?" "No." "Had you a good bed?" "No." "Will you go back to the Hall-by-the-Sea?" "No." And so the little rascal went on telling me all the lies he could invent about Margate and his former good home, the Hall-by-the-Sea."

To the Margate shrimps a separate article was devoted.

' There are two seaside places in England where the sun can be seen at this time of the year to rise from the sea and to set in the sea. The one is Cromer in Norfolk, the other Margate in Kent. The chief exports of Margate are shrimps and grand turbots as "firm as glass and as white as a lily." These are trawled up from "The Falls," a fishing bank which, with the Ridge and the Varne banks between Folkestone and Boulogne, produce the best "butts" (local name for turbots) sent to the London market. In the great Thames estuary, between the North Foreland on the south and Harwich on the north, are thousands of acres of sand plateaus, fatal to ships, but favourable to shrimps. From this great shrimp farm are netted up daily, hourly, from April to October, thousands and ten thousands of shrimps; yet in spite of 
the number caught there does not appear, except at times, to be any falling off of these "sea flies," as they are sometimes called. There are two kinds of shrimps-the brown and the red shrimp. A diversity of opinion obtains as to which is the best eating. The red shrimp is really a prawn, and carries a sword in his head. Examine this sword, and you will see what a formidable weapon it is. The brown shrimp carries claws, the very beautiful construction of which is seldom noticed. It will be found that at the tip of each claw is a tiny little hook, sharp-pointed and curved like a scythe. This hook fits, point and all, into a case, just as a knife fits into its handle. To what use does the prawn apply his sword, the brown shrimp his hooks? Here is a problem for observers to solve. In spite of the advance of education in modern times, the rising generation does not seem to be aware of the presence of "Adam and Eve" in the brown (not the red) shrimp's head. Just below and almost between the horns will be found two feather-like projections. Pull these out slowly and tenderly, hold them up to the light, and you will see "Adam and Eve," and pretty little figures they are.

'As amongst ourselves, there is a feeling of caste among the shrimps. They do not hit it off at all together, but live in quite different places. The red shrimp prefers hard "rossy ground;" the brown yellow delights in sand, and sand only. They differ also in their food, but both species will eat very young mussels and cockles called "trail ; they are more carnivorous than herbivorous. In examining a sample of shrimps, it will be perceived that in one sample the take runs much of a size, while in another sample there 
are shrimps of all sizes, some being not much larger than big fleas. The reason of this is that in some fishing villages along the English coast the custom obtains of riddling the shrimps at sea; i.e. when the net is hauled on deck the shrimps are put into a sieve with iron wires, and riddled over the side of the vessel; the babies fall back into the water to grow, the big ones are consigned to the boiling pot; and there is an art eren in boiling shrimps. This process is called "dusting the stuff." The gauge of the riddle varies in different places, but it is always measured by easily accessible coins. The following are some of the tests used: Threepenny pieces, an old penny and a farthing, twopenny pieces and a sixpence, \&c. At Leigh, near Southend, the men have a rule among themselves, whereby every shrimper is bound in honour to riddle his catch at sea; an excellent example, which should be followed by all shrimpers.

'There exists much animosity between the deep-sea trawlers and the shrimpers : the allegation against the latter being, that they destroy the fry of such fish as soles, plaice, turbots; skates, etc. If the lower end of the mesh of a shrimp-net be examined, it will be found so small as to be capable of catching a needle, and it is without doubt the fact, that the shrimp-nets do destroy an immense quantity of fry. To use a trawler's words, "Them chaps kills basketfulls as would become netfulls; and in course soles is dear." We have seen specimens of little soles from the size of a thumb-nail up to "cats' tong'ues;" and lambs" tongues is a measure exactly representing the size of these murdered innocents killed by the shrimpers.

'The trawlers say no sole is a sole under seven inches 
in lengti.. Skates and rays, not larger than a half-crown cut into a diamond pattern, are also killed, as well as young whitings not so large as big minnows, besides many forms of minute and immature fish-animal lye which the fishermen call "sea vermin," and "rubbish." To lovers of nature, these sea gems in the rubbish are quite as beautiful in design and colouring as many of the works of art turned out by jewellers. Here, for instance, we have the star fish or "five finger," the great enemy to oysters and mussels. Here also we find little fish, with a face like a pantomime mask, called the " hard head" or " hook nose." This little fellow has two sharp curved hooks at the tip of his snout, and the rising generation of shrimpers hook the " hard head" on the tip of their noses, and then chuck them with a jerk backwards over their heads : here then is a new game for London juveniles at the seaside. The shrimpers will readily save some hook-noses if asked so to do.

"The principal shrimping grounds near Margate are the "Queen's Channel," the "Gore," and the grounds below the Nore Light.

"The art of shrimping was first discovered at Margate by Mr. J. Shrubsall, fish merchant, of that town. When he first began, thirty years ago, he has taken from 30 to 100 gallons of shrimps at one haul. In the neighbourhood of Pegwell Bay and Ramsgate Way most of the shrimps are caught by "pushing" - i.e. by a hand-net worked by a man wading. Historians have not recorded, whether the Roman soldiers in Julius Cæesar's time, when off duty from their fortress at Richboro', took to "Tea and shrimps." Londoners do not pay sufficient respect to shrimps, but yet they are of considerable importance, for the London cooks 
know well how to make them do duty for oysters, during the close season for "natives," which, by the way, ends on the 4.th of this month. Shrimping, it must be remembered, is an industry of considerable national importance, especially as affording occupation for the poor fichermen, food for the poor people in London and the midland counties, and training for men and boys who afterwards join the navy and the merchant service. Morecambe Bay may be said to be placed, as regards shrimps, next in importance to the Thames estuary; the Morecambe Bay shrimp fisheries ulone are worth about 4,000l. a year. Shrimps from this part of Lancashire are sent mostly to the vast manufacturing populations of the iron districts and the midland counties. Shrimps afford excellent natural barometers to the fishermen-like plaice they are off into deep water when bad weather is coming, and they "smells the frost a coming." "

In August Frank Buckland returned to London and went for the last time to the Fishery Office, and to the Home Office to present his report.

In this month a large orang-outan arrived in London, and was described in two characteristic articles sent to the 'Daily News.'

The last time Frank Buckland left his house was to visit the orang-outan.

'August 21, 1880.-There is now in London one of the largest orangs that has ever been brought to this country. Young orangs are by no means uncommon, but they are excessively delicate and difficult to rear; in fact, they are only babies. These young orangs, when sitting in their box wrapped in flannels, generally look very grave 
and sedate. They have somewhat the physiognomy of an eastern prince, who has nothing particular to do, yet is fond of being amused by other people. The present orang, however, is an adult, or nearly an adult, and has all his wits about him, and is terribly fierce. He has been brought from Malacca, and is somewhere between four and five feet high, if not bigger. As his brilliant and watchful eyes peer through the bars at the visitors, it will be seen that his physiognomy differs as much from that of the infant members of his family, as does the expression of a child a year or two old from that of an adult man, in full mental and bodily vigour. He is covered with hair of a reddish colour, and is a little bald on the top of the head, giving him rather a professional appearance. He evidently thinks his present apartment is not big enough for him, for he is continuously shaking his cage, and so tremendous is his strength of arm and hand, that should anything give this "wild man of the woods" a chance, it would not be long before he would be off; and then who is to catch him again? Such an event, however, is not likely to happen, as Mr. Orang's teeth, though tremendous weapons, cannot bite through iron chains. There is just space enough between two of the bars for him to put out his hand and arm, and he is continually stretching out his long hairy arm to see if he can clutch anything or anybody with his hand, which, though a veritable hand, is more like a foot. The fingers are small and tapering, very strong, and about five inches long. Both his foot and hand are most admirably adapted for living in trees, his band forming a natural grapnel, by means of which he can swing bimself from branch to branch, while the great toe 
of his foot acts as does the thumb in our own hand. When attempting to walk he makes a very poor go of it, using his long arms to support himself, just as a cripple works his crutches. At home in his tropical forest he doubtless could spin along the tree tops at a Derby pace. The hair about his head is so arranged that he appears to wear whiskers. He has, moreover, a reddish beard, and under this beard is a very remarkable pouch, the use of which has not as yet been clearly ascertained. As, however, it is capable of dilatation with air, it is, in all probability, directly connected with the organ of voice. It is not necessary to go to his native woods to hear him sing, as, when in a temper, his oratorical remarks are couched in language which no one can fail to understand. It is a wonder to me how the natives ever managed to catch him, whether as an infant, or of full growth.

Three great tailless apes are known to naturalists-the gorilla, the chimpanzee, and the orang. The existence of the gorilla was first made known about thirty years ago, when a traveller in the Gaboon country, on the West Coast of Africa, discovered a skull fixed on a post, in a dark and gloomy part of the forest. It was ornamented with broad red stripes, crossed by a white stripe. The natives regarded it as a "fetish," and treated it with the greatest reverence and respect. It was the skull of a very large gorilla. We have never yet seen a full-grown gorilla in this country; but the orang just arrived from M lacca is by far the largest specimen of these apes, and is therefore of the highest interest. Orang-outan, in the Malay language, signifies the "wild man." These "wild men " are found in the islands of Sumatra and Borneo. They are forest 
animals, and rarely seen. The orang is a purely diurnal animal, as the pupil of his eye-like that of a dog, and not of a cat-will tell us. $\mathrm{He}$ is probably the animal which gave rise to the "Satyr," "Pan," and the "Fauns" of Roman times. The islands of the orang's home are nearly all covered with a dense, gloomy, tropical forest, and what is not forest is jungle or swamp. They are nearly under the Equator, and therefore well suited as the habitat of these big apes, especially as fruits are abundant. It is in these forests, where human beings cannot and dare not enter, that the orang is lord and master. Of their habits, and the maximum size to which they attain, nobody -not even the native hunter-can tell us much, if anything. The old males live solitary lives in the forests, but the young ones follow their mother, and are said to stay a long time under her guardianship, and (as may be seen sometimes at the Zoological Gardens) the baby ape clings . round the neck of the mother, who carries her infant about among the tree tops. It is at this time that young orangs are caught. It is probable that somehow or other this adult orang was not caught young, but was trapped or snared when adult.

'The orang is very intolerant of cold; yet his native forests are, when the sun goes down and the fog rises, very cold at night. Under these circumstances, the orang creeps in among the parasitic orchids, and, making a sort of nest, covers himself all over. This habit the animal at Westminster retains, and it will be seen that he is very fond of his blanket, and frequently wraps himself up altogether, leaving just a peep-hole, through which he inspects his visitors. His eyes are very close together, but very

E E 
bright, watchful, and observant; he is also very quick of hearing.

'When a man performs the part of a monkey, whenever he possibly can he stands upright; the orang, on the contrary, whenever he possibly can, goes on all fours. His hand, in fact, is a grapnel. We men have the power of placing the thumb so as to meet the tip of any finger on the same hand -hence the principal superiority of man over all other animals, inasmuch as by means of the thumb he can make himself clothes, procure food, forge weapons, \&c. The thumb of the orang, on the contrary, is on his foot. Lascars and other sailors use their great toes in climbing ropes, and the Australian savages are very clever in climbing up trees and picking up very small articles with the naked feet. Civilised men lose much by not using their great toes, which may be easily educated to work. The orang's foot is admirably contrived for living in trees. When sitting on a flat surface he tucks his legs nnder him, but when sitting on a bough he holds on by means of the thumb of his foot. As regards his brain power, much is jet to be learnt, as, though anatomically similar, the brain of this big monkey is far below the standard of intelligence of even the lowest of the human race. Let us instance one point. No monkey of any species, where the experiment has been tried, would ever put a stick or coal on to an expiring fire; he would sit and shiver by the fire till it goes out. His mind is not sufficiently acute to see the connection between cause and effect, so as to put coal on to keep the fire going. There is another thing, showing the great difference between a man and a tailless ape, such as the orang. If an object be given to a monkey he immediately smells at it, even if 
that object is not meant for food purposes. Human beings do not do this; they trust to the eyes and the touch. Again, when even the most savage of men fight, it is very seldom indeed we henr of their biting each other; but the moment the monkey's "monkey is up," that instant he begins to use his teeth and to bite. "Their teeth are weapons of offence and defence, while our teeth we use instinctively for much more peaceful purposes. When big baboons are introduced to each other for the first time, they generally pretend to yawn. This is really to show each other their long, sabre-like, canine teeth, and to say, "Look out; I have as sharp teeth as you."

"There are so many gentlemen who have leisure and means, that we beg to suggest that those who have the opportunity should make it their pleasure and business to visit some of these orangs in their tropical forests. Let them, for once, leave the gun and rifle at home, and take only the telescope and field-glass, the sketch-book and pencil. Naturalists and anatomists know quite enough of the structure, as compared with man, of the orang, gorilla, and chimpanzee. There are skeletons and skins in abundance of all these in England, but nobody, not even Professor Owen himself, can tell the social manners and customs of an animal from his skeleton and the structure of his muscles. What is wanted now to fill up this vacant gap is an account of the home life of these great apes. This is not to be obtained by shooting and persecuting them; but by meeting them, as it were, in a friendly manner. Mucl has lately been said as to the relationship of man with monkeys. In purely pluysical structure the architecture of the monkey is not uulike that of the human 
being. When, however, the very lowest of the human race is placed alive, and in good health, alongside the very highest of the monkey family, it will be immediately perceived that there is a vast gulf between the two, which has never been bridged over.'

The Centenary of Whitebait was recorded in another article :-

'September 1, 1880.--Her Majesty's Ministers, when sitting down to-day to their whitebeit dinner at Greenwich, should not fail to recollect that the present year commemorates the hundredth year of the eating of whitebait. It was in 1780 that one Richard Cannon, a fisherman of Blackwall, first introduced whitebait as a savoury dish. From that time to the present it has gradually grown in public favour, till at last the industry of whitebait catching has been promoted to an important branch of British fishery industries. This year it was as nearly as possible a case of a "whitebait dinner without whitebait." We have it on the authority of the largest dealer in whitebait in Billingsgate Market, that whitebait fishing has been over now about a fortnight; special boats therefore have been put on, on purpose to get the requisite supply for to-day's dinner. The proper whitebait season is considered by the principal Thames fishermen to begin when Parliament begins, and end when Parliament ends. This is the rule they have gone by for many years past, or, to put it according to the almanack, they begin with their nets in February, and go on to the middle of August. This year Parliament has held its sittings so late, that the whitebait, not being able to wait so long, have adjourned to the sea, thence to return as sprats about next November, 
especially being careful to remember that they ar'e due at the Mansion House on the 9th of November. "Bait," as it is technically called, varies much in size and quality according to the season of the year. Thus, in February and Narch, considerable numbers of "yawlings" aree caught. These are without doubt "yearling" herrings. In June and July the bait run very small, and "heads and eyes" appear in the nets. These are very minute, gelatinous little creatures, so transparent that the bright, silvery eye is the most noticeable portion of them. At various times of the year appear also "Polwigs" i.e. young gobies and "Rooshans," infant weaver fish, as likewise "buntings" (brown) and red shrimps, sand eels, sticklebacks, \&c. We have carefully examined a sample of the "bait" similar to that which will be caught to-day for the dinner. It consists almost entirely of young sprats - lovely little fish, as silvery as a new shilling, and in excellent condition. It has lately been alleged that killing this fry is a wasteful process, and that they should be allowed to grow into adult fish, but in the estuary of the Thames sprats are not falling off-in fact, it often happens in the winter months that Billingsgate market is overstocked with sprats in consequence of so many "garvies" (Scotch for sprats) being sent from Inverness and other firths of Scotland. This also accounts for the fact that, when abundant, sprats are largely used for manure for the Kentish hop-gardens and turnip fields.

'The value of whitebait as whitebait is very large. One firm alone pays $100 l$. a week in wages during the season, and at anotlier place about 1,000l. a year is coming in as wages to the whitebait catchers. Under these circun- 
stanoes it is not likely that Parliament will ever be asked to make it illegal for the fishermen to catch or the public to eat whitebait. As regards the origin of the term whitebait, in former times these little fishes were used as "bait" for the crab pots; then as now they were very bright and silvery, and were called "white-bait," in contradistinction to other baits that were not white. When they became fashionable as food for Londoners they still retained their name "whitebait," by which appellation they will probably be still known at ministerial dinners for many years to come.'

A severe relapse occurred, and Frank Buckland now well knew his days were numbered; yet, notwithstanding the distressing nature of his malady, he gave unremitting energy to his literary work.

Articles from his pen continued to appear in the daily papers and 'Land and Water.'

A new edition of the 'Natural History of British Fishes' was carried through; also a revised edition of 'White's Natural History of Selborne:' both completed in the last month of his life.

He arranged and partly revised a series of his articles, which were published shortly after his death under the title of 'Notes and Jottings from Animal Life.'

Those who saw him during his long illness will well remember how soon the distressed look of disease would give way to his old bright smile, and even merry laugh, as he poured out his last droll story, or quaint bit of knowledge, till he would stop and say, 'Is it not strange, when I am talking to you I forget my illness?' At first it seemed hard to be cut short in full career of energ! and usefulness. 
He likened laimself to Job, and wondered why he was so sorely tried; but when the end drew near, he bowed himself to the Supreme Will, and, not unconscious of error, or that a nature so vehement was not always subject to due control, he received the last rites of Christianity, and prepared to die at peace with God and man. ' God is so good,' he said, 'so very good to the little fishes, I do not believe He would let their inspector suffer shipwreck at last.'

'I am going a long journey where I think I shall see a great many curious animals. This journey I must go alone.'

He died on December 19, and his body was laid to rest in Brompton Cemetery on Christmas Eve 1880.

'I think it not improbable,' he wrote in his private diary in 1846 , 'that, in a future state, the mind will be allowed a greater scope of knowledge, and the gates of omniscience will be thrown open to it, so that those things, which it now sees through a glass darkly, will be opened to the view and understanding. O most glorious reward, for a mind occupied here on earth in investigating the wonderful works of the Creator, from the magnificent and stupendously grand scene of geology, and the theory of the heavens, to the minute and delicate construction of a microscopic animalcule, or the immeasurably fine thread of a plant!'

His last work was the preface to the 'Natural History of British Fishes,' which was sent to press two days before his death. It was thought out in nights of pain, and dictated in the morning in intervals of gasping breath.

After insisting on the natioual importance of British fisheries, he continues: ' $I$ have another object in writing 
this book; it is to endeavour to show the truth of the good old doctrine of the Bridgewater Treatises, which have so ably demonstrated the power, wisdom, and goodness of God as manifested in the Creation. Of late years, the doctrines of so-called Evolution and Development have seemingly gained ground among those interested in natural history; but to put matters very straight, I steadfastly believe that the Great Creator, as indeed we are directly told, made all things perfect and "very good" from the beginning; perfect and very good every created thing is now found to be, and will so continue to the end of time. I am very willing to prove my case, by holding a Court at any time or place, before any number of people of any class. I would impanel a jury of the most eminent and skilful railway and mechanical engineers, while the only witnesses I should call would be the fish fresh from the deep-sea trawler, the city fish market, or the fishmonger's slab: I would adduce from them evidence of "design, beauty, and order," as evinced in such as the electric organs of the torpedo, the gun-lock spine of the file-fish, the water reservoirs and spectacles of the eel, the teeth of the gilt-head bream, the anchor of the lump sucker and remora, the colouring of the perch and bleak, the ichthyophagous teeth of the pike, shark, and silvery hair-tail, the tail of the fox shark, the prehensile lips of the dory and sprat, the nose of the barbel and dogfish, the resplendence of the arctic gymnetrus and scabbard fish, the dagger in the tail of the sting-ray, the nest of the stickleback, the armour plates of the sturgeon, the nostril-breathing powers and store of fat in the salmon; migrations of the salmon, nerring, pilchard, sprat, and mackerel; and, above all, the 
enormous fertility of fishes useful as food to the human race. I am satisfied that I should obtain a verdict in favour of my view of the case, namely, that in all these wonderful contrivances there exists evidence of design and forethought, and a wondrous adaptation of means to an end.'

Thus to trace the power of the Creator in His works, and to increase the use of His creatures to mankind, were to Frank Buckland the chief ends of natural history, and the chief purpose of his life.

He was indeed slow, nay, unwilling, to admit the truth of Darwin's teaching, and of the theory of evolution, too often represented as superseding the necessity of a Creator, and the evidence of design; and he often humorously but vehemently protested against his supposed relationship to his monkey pets. The point of his protest was against the notion that chance could produce the order of the universe, or a monkey develop itself into a man.

To him, the old notion of a universe formed by a fortuitous concourse of atoms, was not more unreasonable, than the notion of the harmony of Nature, or the structure of any beast or fish, being the result of a mere chance combination of circumstances. Each alike must beget chaos.

Darwin himself intended nothing in his theories adver'se to religion, and, while exploring the depths of the history of animal life, saw that the origin of life, the power and laws of reproduction, the energy of variability, and that correlation of growth, which controls variation and educes harmony, were alike inscrutable. ${ }^{1}$

Evolution, therefore, is but a mode of creation, and each varying birth, however subject to natural law, an act

'Origin of Species, 6th edit., pp. 10, 106, 421. 
of creative power; and could a chain of development be traced throughout, even from inert matter, through protoplasm and zoophyte, through reptile, mammal and ape, direct to man, then, unless the clod endowed itself with motion, sense and reason, the sum would be the same-that God formed man out of the dust of the ground, and breathed into him the breath of life.

How gradual or how rapid changes of animal form have been may well be debated. Plants vary much by sports, errant seedlings, which again are specially variable and favour rapid change. The analogy of plants, the more plastic nature of varieties among animals, the defined character of species and lack of intermediate forms, may indicate that changes in animal forms were often more marked or sudden than some have supposed.

However this may be, the controversy, whose fires are but now dying out, between those who admire in the present system of nature the evidence of design, and those. who would trace back the laws of growth under which that system has been built up, shows (like the gold and silver shield) but two sides of the same truth. As Copernicus and. Newton disturbed but to enlarge men's knowledge of the wonders of the hearens, and Dr. Buckland and other geologists widened the former limited cunceptions of the structure of the earth, so the more profound and complex the laws of the history of animal life are found, the deeper should be our apprehension of the Creative Power and Skill which Frank Buckland and his father loved to explain and illustrate.

By his will Frank Buckland gave his Museum to the nation, to be retained at South Kensington; the rest of his 
property he bequeathed to his widow, after whose death $5,000 l$. was given to found a lectureship on fish culture, in connection with his Museum.

The Museum contains about tour hundred casts of fish, mostly moulded with his own hands, besides a large collection of other objects, illustrating the science of fish and oyster culture.

A marble bust of Frank Buckland has been placed, by subscription, in his Museum.

From among many letters testifying to the public and private loss Frank Buckland's death occasioned, the following ' Recollections,' sent by Mr. Archibald Young to the 'Scotsman,' may be quoted:

'Having been intimately associated with Mr. Buckland for eleven years, we naturally wish to express our sorrow for his death, our respect for his memory, and to bear our testimony to his many gifts and attractions as a colleague and a companion. We first made his acquaintance in 1870, when appointed along with him to inquire into and report upon the effect of recent legislation on the Salmon Fisheries of Scotland. During that year we travelled together for four months throughout Scotland, visiting all the fishing districts, and inspecting upwards of sixty salmon rivers, so that we had ample opportunities of noticing Mr. Buckland's quickness of observation, and his intimate acquaintance with the habits of the salmon, and of admiring his kind, genial, and obliging disposition. At that time he was in the prime of life, somewhat under the middle height, but broad-shouldered and powerfully built, with a clever pleasant face, in which the most noticeable features were the large, dark, expressive eyes. He was 
about the most true and genuine man we ever met, without a particle of affectation, saying what he thonght and felt simply and naturally. He learned to have a thorough enjoyment of life in all its phases; and it would have been difficult to say whether he was most at home in the polished society of a luxurious country house, or while engaged in demonstrating the anatomy of a salmon, a herring, or a lobster to a group of fishermen assembled round a fishing-boat on the beach. At that time he took but little care of himself, and thought nothing of wading across a river up to his waist, even though he could not change his wet clothes for hours afterwards; or minutely examining the structure and details of a salmon-ladder while up to his knees in water. At that period he seemed to have a wonderful amount of latent caloric, and never appeared to feel cold. He was a great smoker, and to him a pipe or a cigar was an absolute necessary of life. Yet his constant smoking never seemed to spoil his appetite. or to lessen his natural vivacity and flow of spirits. On every subject, which bore upon his special study of natural history, whether connected with our inquiry or not, he took a lively interest. In politics, too, he felt keenly; and was a strong Conservative and Church of England man.

'In the close of 1876 , we had again the pleasure of being associated with Mr. Buckland in an inquiry into the Crab and Lobster Fisheries in Scotland; and an excellent specimen of his happy manner of dealing with subjects in natural history, which in other hands would prove tiresome and uninteresting, will be found in the paper ir the appendix to the Report "On the Natural History of Crabs and Lobsters." What will those who 
object to crab and lobster suppers say to the following extract? - "The presence of phosphorus in the lobster is of great importance to the consumers of these sea luxuries; there is no substance which conveys phosphorus so readily into the human system in an agreeable form, and which the system so readily and quickly assimilates, as the flesh of crabs and lobsters. For this reason lobsters, crabs, and oysters should form the diet of those engaged in business or arduous literary pursuits, where there is much wear and tear of the brain powers by thought, and therefore an extra supply of phosphorus is required for the food of the brain. It is for this reason, I imagine, that lobsters and crabs are generally eaten and most esteemed for supper. The brain towards night begins to feel a little exhausted, the lobster, crab, or oyster quickly supplies the want, and the system immediately feels the effect." In August and September 1877, we were again the colleague of $\mathrm{Mr}$. Buckland in an inquiry into the Herring Fisheries of Scotland, during which not only the coasts of Scotland were visited, but likewise the Hebrides and the Orkney and Shetland Islands. Mr. Buckland's individual contributions to the report, published in 1878, which followed upon this inquiry, are highly interesting, and consist of two papers in the appendix entitled "Notes on the Natural History of the Herring," and the "Garvie Fisheries of Scotland."

"Not very long after the publication of this report, Mr. Buckland's health began to fail, and when we next met him, on the inquiry connected with the Salmon Disease, we were struck with the change in his appearance. The robust frame had shrunk, and the healthy cheek paled. 
He seemed but the shadow of his former self. Yet his interest in his favourite pursuits was unabated, and his mind was as actively vivacious as ever. But sitting in close rooms and examining witnesses during a long day exhausted him, and brought on distressing attacks of asthma, and he was ultimately obliged to give up assisting at the concluding inquiries.

'We have hitherto spoken only of Mr. Buckland's labours with reference to the Scotch fisheries. As memorials of his more special work connected with the fisheries of England and Wales, nineteen annual reports remain, of which the last, published in 1880 , contains an excellent account of the natural history of salmon. In 1879, a most able and exhaustive report on the Sea Fisheries of England and Wales was drawn up by Mr. Buckland and Mr. Walpole; and one of the best things lately written by Mr. Buckland occurs in the appendix, and is entitled "A Short History of the Commercial," Trawl-net, Drift-net, and Hook Fish alluded to in the foregoing Report."

"In "Land and Water," of which he was the chief pillar and support, $\mathrm{Mr}$. Buckland continued to write almost until the close of his career, and the number published on the 18th of the present month contains a paper from his hand on the different species of oysters. Writing, indeed, seems to have been the solace and amusement as well as the business of his life. He wrote a great deal, and easily and rapidly, not only at his office and at his house, but in railway carriages, steamboats, and other public conveyances. His writings, like those of most men who have, written so much and so rapidly, are unequal, but the best 
of them are admirable. The style is thoroughly original, and wonderfully descriptive, bringing the object or scene written about clearly and vividly before the reader's eye; and it may safely be affirmed that no one has ever done more to reuder natural history popular and attractive.

'Mr. Buckland was a delightful companion, kind, helpful, of a joyous buoyant temperament, and abounding in anecdotes of his medical student days; of his career as doctor in the Life Guards; of his Museum of economic fish-culture at Sonth Kensington; of Jamrach's menagerie ; of the Zoological Gardens; of everything in and about London and elsewhere relating to natural history; all told with a vigour and spirit that added to their intrinsic interest. He was deservedly and justly a public favourite; but it is only his intimate friends and associates who can know what a good and gifted man has passed away from among us into the silent land.'

'No more zealous, truth-loving, or painstaking man,' said another friend,' 'ever studied more earnestly or described more accurately the various gifts and instincts, the nature and habits of birds and beasts. A quaint vein of humour runs through his writings, which must commend them to every reader, especially to the young; and few writers have conveyed more varied and useful information. His conversation, which generally turned upon subjects connected with his favourite study, was equally animated, instructive, and amusing. Who that knew him has ever forgotten his hearty jocund laugh, and the half-comic earnestness with which he enforced his favourite dogmas?

1 Mr. George Rooper: President's Address to Hertfordshire Naturnl History Society, 1883. 
Buckland emulated White and Waterton in never stating anything as a fact, of which he had not satisfied himself by actual experiment. I once found him cooking a piece of a dead kelt. "Good gracious!" I said, "how can you eat anything so abominably nasty?" "No doubt," he said, "it is nasty enough, but how can I say so unless I have tried it?"

'I remember his earnest wistful face, as he contemplated a large oyster, of what kind I know not, but it was almost as big as a cheese-plate. He looked at it once or twice with an evident wish to experiment upon its flavour, but although blessed with a very strong stomach, his resolution failed him, and he resolved to make the experiment vicariously. He called in a dustman, and on the principle of fiat experimentum in corpore vili, offered him a shilling to eat it. The spirit of the dustman was willing but his stomach weak, and he recoiled from the undertaking. Buckland increased the bribe by an added pot of porter. On this the dustman devoured half the tempting bivalve, but suddenly retired without completing the experiment, and the precise flavour of that oyster is still locked unrecorded in the dustman's breast.

' Well, he has passed away and has left his works behind to speak of him. His works, as his memory, will long endure, a monument of patient, kindly, and scientific observation.'

The successive exhibitions of pisciculture at Norwich, at Edinburgh, and in London, and their remarkable popularity, are no slight evidence of the extent to which Frank Buckland had evoked a popular interest in his farourite science. 
Those who would know Frank Buckland better should read his books, which, after all, form his best portraiture. In these, the incidents of his life, his pets, his queer companions, are made familiar, and on this thread are strung a find of curious information and droll anecdote. These seem to talk to us in his old tones, and recall his sparkling ere and merry laugh, his restless energy, and tenderness of feeling for man and beast.

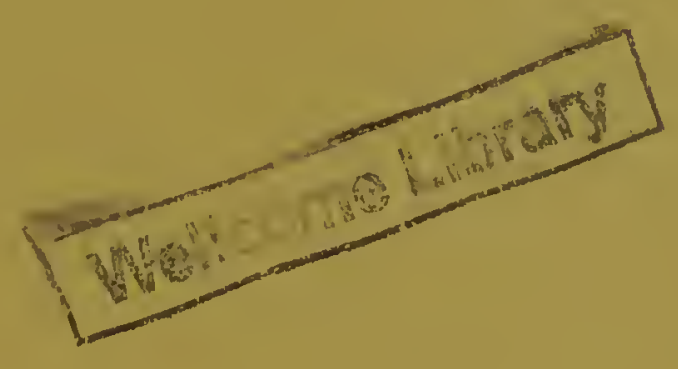

PRISTRD BY

SPOTTISWOUD\& ATD \&O., NEW-STIREET SQUARE

เoxีก)

If $\mathrm{F}$ 

With Portrait and IIlustrations, crown 8ro. 12s, $6 d$.

\section{NOTES AND JOTTINGS FROM ANIMAL LIFE.}

\section{By the late FRANK BUCKLAND.}

\section{OPINIONS OF THE PRESS.}

'A chatty, and entertaining series of articles, bristling with information concerning places far off and near at home as well. The volume is certain to prove a favourite in the hands of young and old alike.'-OBSERVER.

'In taking up Mr. Buckland's volume one is sure to light upon something of interest, narrated or described in a style which is lively rather than refined or careful, but which is an exception to the rule that easy writing makes hard reading.'

Saturday Review.

'A book brimful of anecdote and animal adventures, delightful reading for all times and places.'-THE GUARDiAn.

'Cannot fail to amuse as well as instruct.'-Daily TeLegraPH.

' These papers cannot fail to delight anyone blessed with a taste for the curious and less obvious sides of natural history.... The whole book is a good example of a difficult yet fascinating kind of writing.'-ACADEMY.

'The four hundred pages of wlich the book consists is crammed full of interesting notes of all kinds, some of them accompanied by illustrations. ... The entire contents of the book, from the first page to the last, including a well illustrated chapter on the Great Sea Serpent, will be equally interesting and valuable.'

JouRNAL OF Forestry.

'Contains several illustrations, not the least attractive being the photograph of the lamented author himself as he appeared in his sanctum in Albany Street, with a gigautic salmon as one of his supporters. This admirable and characteristic likeness will add to the value of the book, which will nuake an admirable gift book, whether for young or old readers, wlio have a taste for natural history.'

JOHN BULL.

'In a very well got up volume we have a collection of papers by Mr. Buckland. .... The papers thus collected are of various linds and are all interesting They have, indeed, something more than the ordinary interest of such essays. Frank Buckland had the art of projecting his personality with such productions far more than most men, and he has been eminently successful in doing so in this case. The result is that in reading what he has written, you feel as if you were enjoyng a conversation with him.'-The Scotsuan.

' This volume is a delightful treasury of quaint, personal confession, as well as of scientific knowledge. It is marked not only by keen obscrvation, but by humanity and fine insight, and all that these imply.... To the young especially, the book should be recommended : to them it will prove a sourcc of pure delight, exhilarntion, and knowledge.'-British Quarterly ReviEw.

'We can cordially recommend this volume, to those cspccially of our readers who are about to enjoy a summer holiday.'-The SPECTATor.

' For some years to come such essays as those which fill this volume will be read for the earnest love of nature which they show, and the considcrable nower of observation and illustration they exemplify, as wcll as the geniality and freshness of the style in which they are written.'-STANDARD.

London: SMITH, ELDER, \& CO., 15 Watorloo Place. 


\section{RURAL FNGLAND.}

'A series of boolis of really incomparable freshness and interest.'-A THEN

'Books unsurpassed in power of observation and sympathy with natural nijects by anything that has appecered since the days of Gilbert White.'-DAnx News:

\section{WORKS BY RICHARD JEFFERIES.}

\section{ILLUSTRATED EDITION OF 'THE GAMEKEEPER AT HOME.'} Large crown 8vo. 10s. $6 d$.

\section{THE GAMEKEEPER AT HOME;}

Or, SKETCHES OF NATURAL HISTORY, RURAL LIFE, AND POACHING.

With 41 Illustrations, specially druwn for the Work by CharLes WHYMPER.

*** Also the THIRD EDITION, without Illusirations, crown 8vo. 58.

'Delightful sketches. We do not need the author's assurance that his facts have been gathered from personal observation. This is so obvious from every page that, excepting the "Natural History of Selborne," we remomber uothing that has impressed ns so certainly with the conviction of a minute and vivid exactuess. The lover of the country can hardly fail to be fascinated whenever he may happen to open the pages. It is a book to read and keep for reference, and should be on the shelves of every country gentlemau's library.'SATURDAT REVIEW.

\section{ROUND ABOUT A GREAT ESTATE.}

'To read a book of his is really like taking a trip into some remote part of the country, where the surroundings of life remain very much what they were thirty or forty Jears ago. Mr. Jefferies has made up a very pleasant volume.'-THE GLoBE.

"The volume before us is so charming in its style, and exhibits such familiarity with the by-ways of rural life, that it cannot fail to enhance the reputation of its author as a delineator of rural society, and as an observant stndent of animate and inanimate nature.'-THE ECHO

THIRD EDITION. Crown 8vo. 7s.6d.

\section{WILD LIFE IN A SOUTHERN COUNTY.}

"A volume which is worthy of a place beside White's "Selborne." In closeness of observation, in power of giving a picture far beyond the power of a mere word-painter, he is the equal of the Selborne rector-perhaps his superior. The author's observation of man is as close and as true as his observation of the lower animals. This is a book to read and to treasure.'-THE ATHEN

- A pleasanter companion it would be hard to find. The anthor is clearly a man of education and intelligence. Notbing seems to escape the author's notice. Always full of pleasant talk and ingeuious fancy, there is not a dull page in his note-book. We mnst send our readers to wander for themselves through the delightful pages of "Wild Life" with certainty of finding instruction and amusement of the best kind.'-STAKDARD.

\section{Crown 8 vo. $5 s$. \\ THE AMATEUR POACHER.}

' Unsurpassed in power of observation and sympathy with natural objects by anything that lias appeared since the days of Gilbert White.'-DATY NEWS.

- We have rarely met witl a book in whichso much that is entertaining is combined with matter of real practical worth. This fascinating and iutcrestiug volume is the work of a man of keen and cultured observation, and will afford delight and instruction to all.'-'ГHE GrAPHIC.

" The sketches of country life are full of the same bright colouring, and instinct with the sauje love of nature and natural scenes which distınguish the author's previous works. His descriptions are gems in their way.'-ExAMINER.

2 vols. crown 8ro. $12 s$.

\section{HODGE AND HIS MASTERS.}

- The one great charm of Mr. Jefferies' writings may be summed up in the single word "graphic." He has a rare power of desoription, and in "Hodge and his Masters" me find plenty of good reading.'-STANDARD.

'Mr. Jefferies knows his ground well and thoroughly, and writes with much of his wonted straightforwardness and assurance..... Pleasant and easp reading throughout.'-ATHEN.ELM.

London : SMITH, ELDER, \& CO., 15 Waterloo Place. 



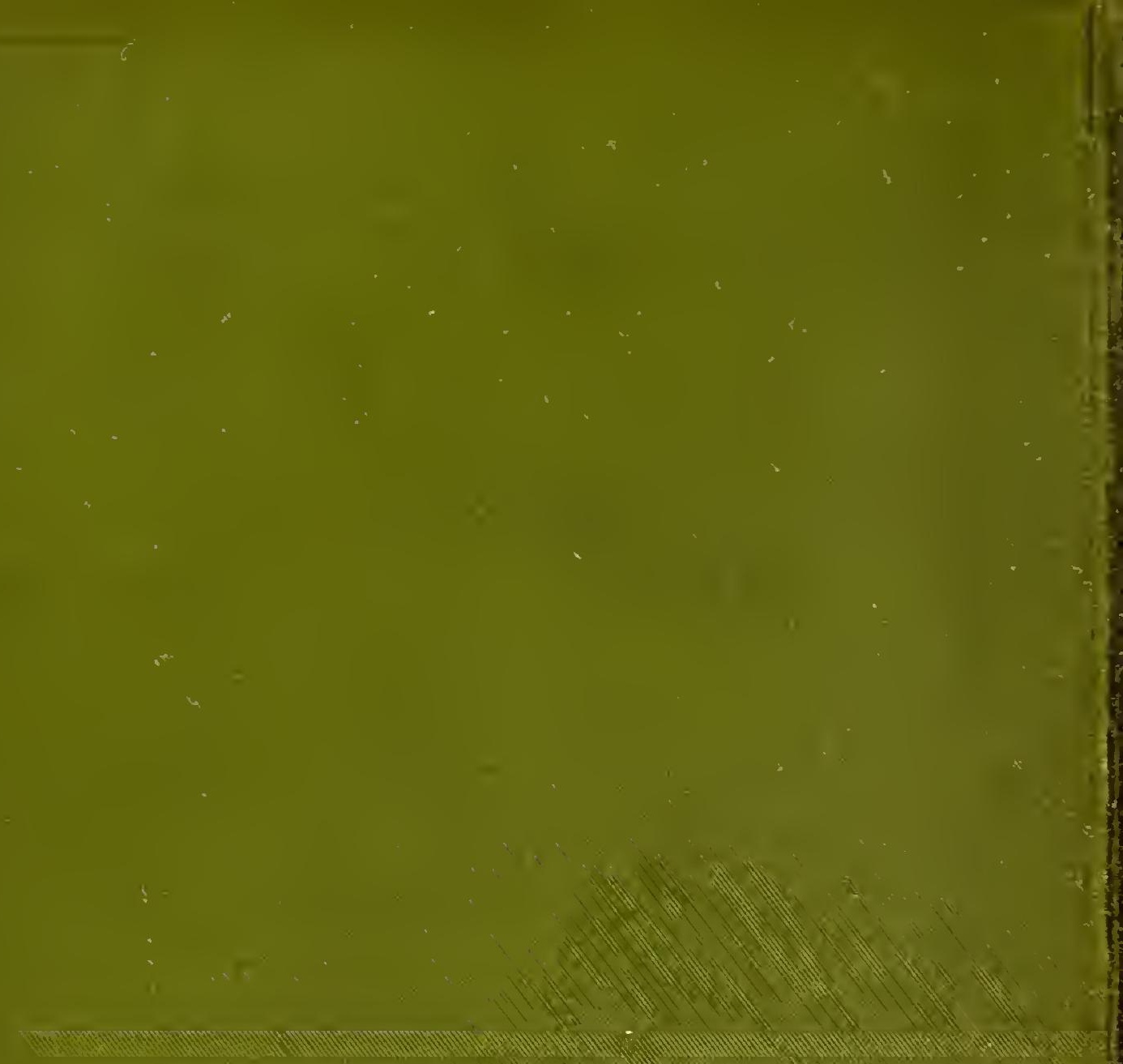

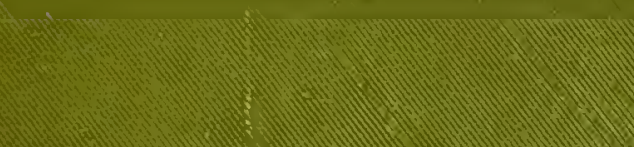

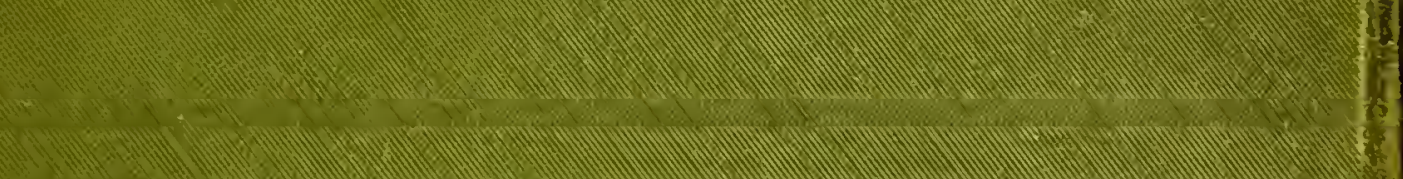

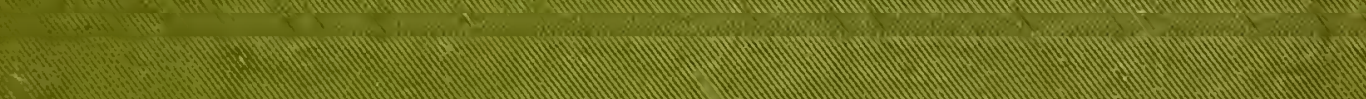

19.

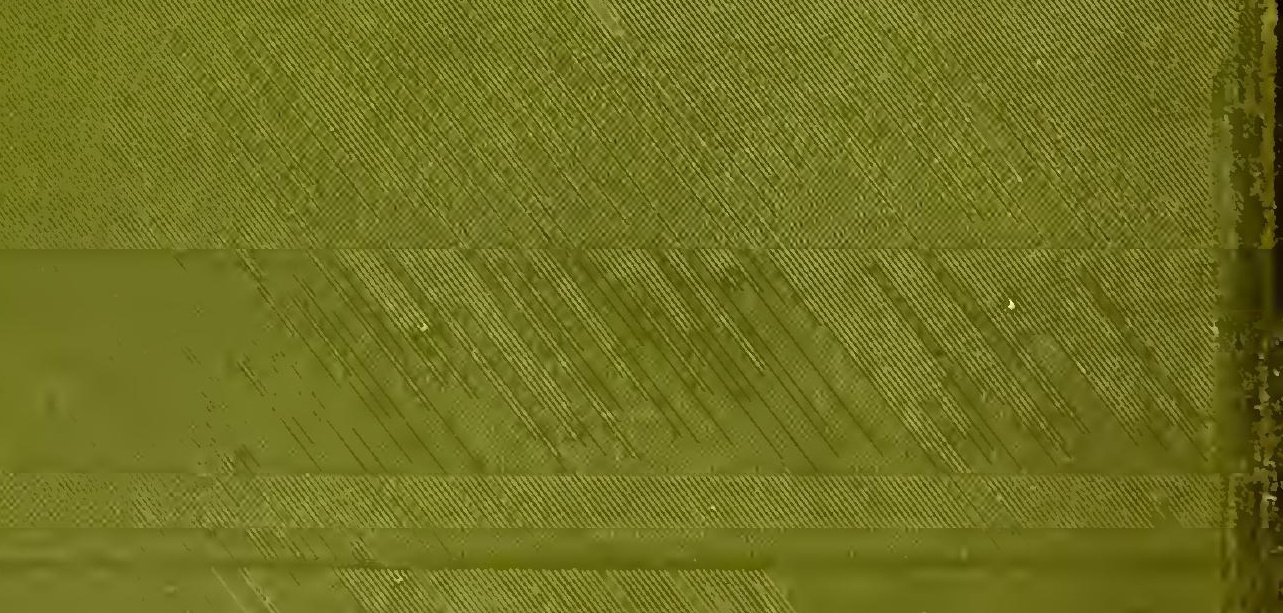

